\title{
RYNEK KAPITAŁOWY - oszczędności i inwestycje
}

redakcja naukowa Teresa Czerwińska i Alojzy Z. Nowak
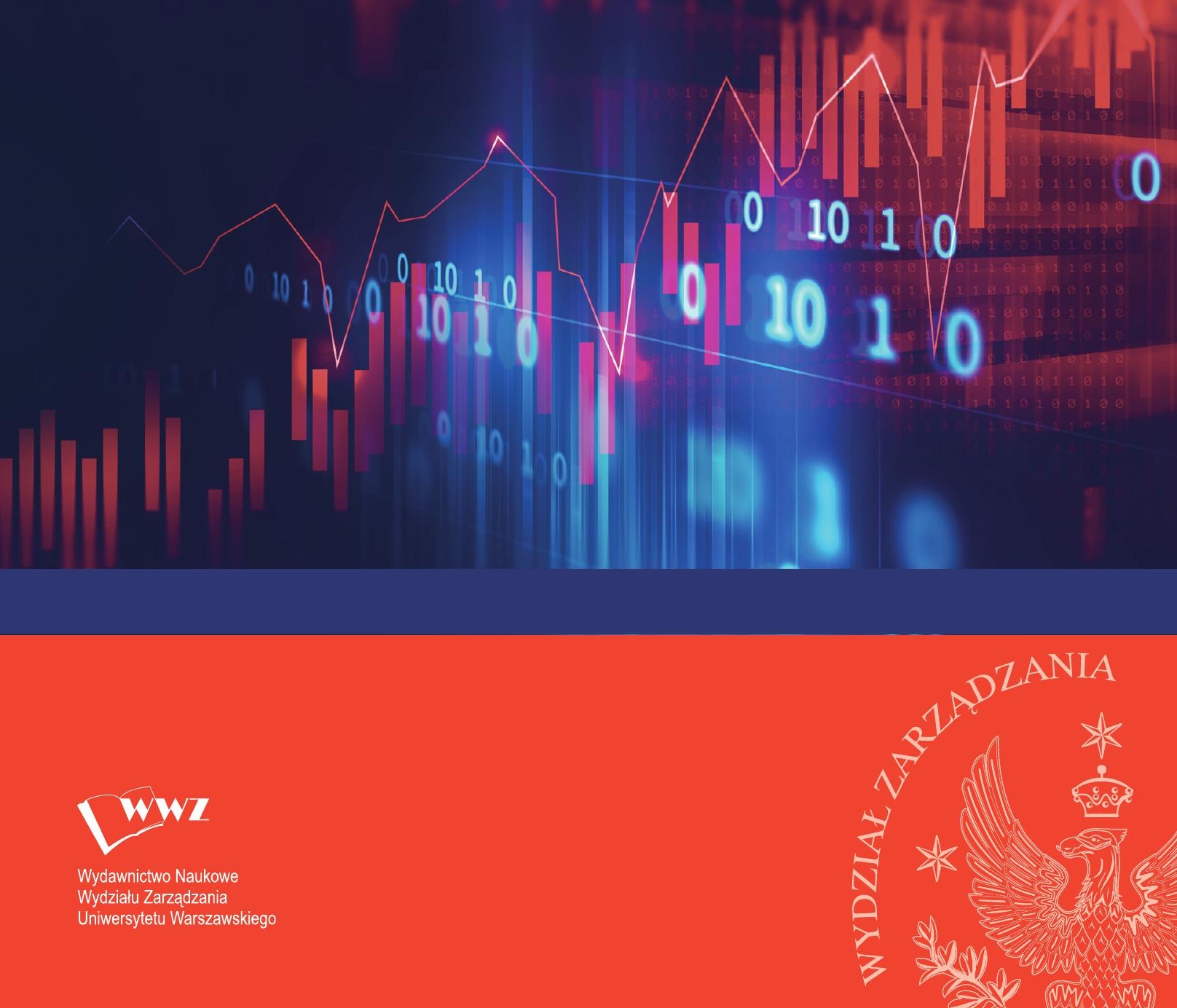


\section{RYNEK KAPITAłOWY \\ - OSZCZĘDNOŚCI I INWESTYCJE}




\section{RYNEK KAPITAKOWY \\ - OSZCZĘDNOŚCI I INWESTYCJE}

REDAKCJA NAUKOWA TERESA CZERWIŃSKA ALOJZY Z. NOWAK

WARSZAWA 2019

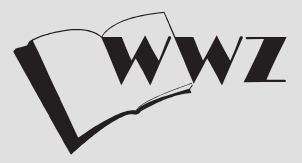

Wydawnictwo Naukowe Wydziału Zarządzania Uniwersytetu Warszawskiego

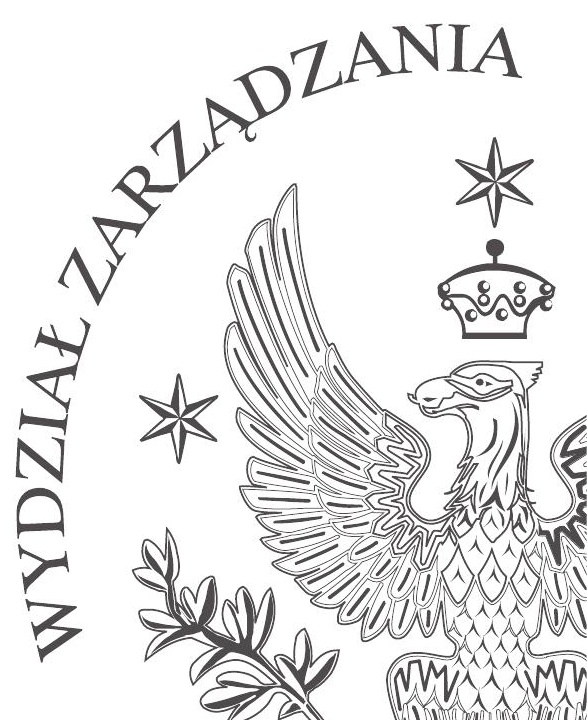


Recenzenci naukowi: dr hab., prof. ucz. Teresa Czerwińska dr Marek Dietl prof. dr hab. Andrzej Gospodarowicz dr Paweł Górecki prof. dr hab. Marian Górski dr hab. Beata Kozłowska-Chyła prof. dr hab. Alojzy Z. Nowak dr Iwona Sroka prof. dr hab. Jan Turyna

Redakcja: Jerzy Jagodziński, Anita Sosnowska

Projekt okładki: Agnieszka Miłaszewicz

(C) Copyright by Wydawnictwo Naukowe Wydziału Zarządzania Uniwersytetu Warszawskiego, Warszawa 2019

Publikacja dofinansowana $z$ dotacji na utrzymanie potencjału badawczego na Wydziale Zarządzania Uniwersytetu Warszawskiego

ISBN: 978-83-66282-10-0

e-ISBN: 978-83-66282-12-4

https://doi.org/10.7172/978-83-66282-12-4.2019.wwz.5

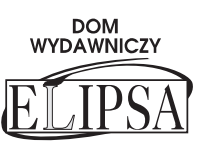

Opracowanie komputerowe, druk i oprawa:

Dom Wydawniczy ELIPSA

ul. Inflancka 15/198, 00-189 Warszawa

tel. 2263503 01, e-mail: elipsa@elipsa.pl, www.elipsa.pl 


\section{Spis treści}

Wprowadzenie

\section{Rozdzial 1}

Advanced Emerging Patchwork (Tadeusz Winkler-Drews) $\ldots \ldots \ldots \ldots, 11$

\section{Rozdział 2}

Wskaźniki CAMEL jako czynniki determinujące emisję obligacji typu contingent convertibles (Jowita Grzelak) .................... 5

\section{Rozdział 3}

Wpływ światowego kryzysu finansowego 2008 na efektywność europejskich rynków akcji (Jacek Karasiński)

\section{Rozdzial 4}

Implementacja i efektywność metod uczenia maszynowego w optymalizacji algorytmicznych strategii inwestycyjnych (Przemystaw Ryś, Robert Ślepaczuk)

\section{Rozdzial 5}

Poziom i struktura aktywów finansowych gospodarstw domowych

w Polsce jako bariera rozwoju rynku kapitałowego - analiza

w kontekście unii rynków kapitałowych (Alfred Janc, Krzysztof Waliszewski) ............................... 101

\section{Rozdział 6}

Udział funduszy inwestycyjnych w oszczędnościach gospodarstw domowych w latach 2008-2018 w Polsce (Tomasz Orlik) ... 


\section{Rozdział 7}

Inwestorzy indywidualni wobec relacji inwestorskich emitentów obligacji (Kamil Gemra, Janusz Maruszewski) .................... 137

\section{Rozdzial 8}

Globalny rozwój i perspektywy implementacji kryptowalut a stan tego rynku w Polsce (Ireneusz Miciuta) 


\section{Wprowadzenie}

Od kilku lat Wydział Zarządzania podejmuje próbę analizy najważniejszych tendencji i zjawisk zachodzących na światowym oraz polskim rynku kapitałowym. W serii publikowanych corocznie od 2014 roku monografii naukowych poruszaliśmy już problemy rynku kapitałowego wobec wyzwań dekoniunktury, skupiliśmy się na najważniejszych kwestiach inwestowania na rynku kapitałowym w warunkach kryzysowych, w celu redukcji negatywnych efektów wówczas występujących czy badaliśmy polski rynek kapitałowy z punktu widzenia efektywności i ryzyka, jakie może generować. W czwartej z cyklu publikacji zaprezentowaliśmy szanse i bariery występujące na naszym rynku kapitałowym, w następnej zaś podjęliśmy próbę upowszechnienia wśród kadry naukowej i środowiska akademickiego specjalistycznej wiedzy o polskim rynku kapitałowym, perspektywach jego rozwoju, kluczowych projektach służących rozwojowi tego rynku. Obecna, szósta z kolei książka, nosząca tytuł „Rynek kapitałowy - oszczędności i inwestycje”, bazuje głównie na dorobku Konkursu na referat naukowy nadesłany na VII Kongres Rynku Kapitałowego, którego ideą było zebranie najlepszych artykułów dotyczących aktualnych problemów i kierunków rozwoju rynku kapitałowego, perspektyw implementacji nowych rozwiązań, produktów i usług dla inwestorów i emitentów, nowych rozwiązań technologicznych wspierających rozwój infrastruktury rynku kapitałowego w zakresie obrotu, rozliczeń i komunikacji z emitentami, modelowania i prognozowania zjawisk oraz strategii inwestowania i zarządzania ryzykiem na rynku kapitałowym.

Niniejszą monografię, wydaną przez Wydawnictwo Naukowe Wydziału Zarządzania Uniwersytetu Warszawskiego, otwiera artykuł autorstwa Tadeusza Winkler-Drewsa pt. „Advanced Emerging Patchwork”, w którym autor ocenia sytuację ekonomiczną i finansową dziewięciu rynków (brazylijskiego, czeskiego, greckiego, węgierskiego, malezyjskiego, meksykańskiego, Republiki 
Południowej Afryki, tajlandzkiego i tureckiego), sklasyfikowanych przez FTSE Classification of Markets jako Advanced Emerging, w latach 2002-2016. Ocenę warunków makroekonomicznych opiera zaś na analizie inflacji i PKB.

W następnym artykule pt. „Wskaźniki CAMEL jako czynniki determinujące emisję obligacji typu contingent convertibles" Jowita Grzelak stawia hipotezę, że wskaźniki CAMEL, reprezentujące adekwatność kapitałową, jakość aktywów, jakość zarządzania, efektywność i płynność banków, wpływają istotnie statystycznie na emisję obligacji warunkowo zamiennych, tzw. CoCo bonds, za pomocą których odbywać się ma proces konwersji długu na kapitał akcyjny. Zjawisko to zostało wyodrębnione przez dyrektywę BRRD, dotycząca restrukturyzacji i uporządkowanej likwidacji banków, tzw. Resolution, która zakłada m.in. koncepcję bail-in, czyli przeniesienia skutków upadłości na akcjonariuszy i wierzycieli. W tym celu autorka przebadała 65 banków notowanych na europejskich giełdach papierów wartościowych w okresie 2000-2018.

„Wpływ światowego kryzysu finansowego 2008 na efektywność europejskich rynków akcji" to przedmiot analizy Jacka Karasińskiego, który stara się odpowiedzieć na pytanie, czy światowy kryzys finansowy 2008 negatywnie wpłynął na efektywność wybranych europejskich rynków akcji w formie słabej. Swoje badanie przeprowadził on dla trzynastu wybranych indeksów uwzględniających wszystkie akcje notowane na różnych europejskich giełdach w latach 2005-2018, w ramach trzech różnych testów normalności rozkładów stóp zwrotu.

Przemysław Ryś i Robert Ślepaczuk w swoim artykule pt. „Implementacja i efektywność metod uczenia maszynowego w optymalizacji algorytmicznych strategii inwestycyjnych" formułują i analizują metody uczenia maszynowego (machine learning, ML), adekwatne do specyfiki zagadnienia optymalizacji parametrów strategii inwestycyjnych. Stwierdzają oni, że najważniejsze wyzwania wynikają z wrażliwości wyników strategii na małe zmiany parametrów oraz z występowania licznych, lokalnych ekstremów, nieregularnie rozłożonych w przestrzeni rozwiązań. Stawiają również hipotezę, że testowane metody ML wybierają strategie ze zbliżoną wartością do maksymalnego kryterium optymalizacyjnego, ale wykonują to działanie w istotnie krótszym czasie niż standardowe podejście przeszukujące całą siatkę parametrów.

Dwa kolejne artykuły zaprezentowane w naszej monografii poruszają istotny problem oszczędności. Alfred Janc i Krzysztof Waliszewski w artykule pt. „Poziom i struktura aktywów finansowych gospodarstw domowych w Polsce jako bariera rozwoju rynku kapitałowego - analiza w kontekście unii rynków kapitałowych" dokonali prezentacji poziomu i struktury aktywów finansowych gospodarstw domowych w Polsce jako bariery dla rozwoju rynku kapitałowe- 
go w kontekście europejskiej unii rynków kapitałowych; barier rozwoju rynku kapitałowego w Polsce z punktu widzenia inwestorów indywidualnych oraz unii rynków kapitałowych jako projektu kładącego nacisk na transfer oszczędności w postaci lokat bankowy na rynek kapitałowy. Poddali również analizie znaczenie oszczędności gospodarstw domowych w ujęciu mikro- i makroekonomicznym. Co ważne, sformułowali rekomendacje i niezbędne działania dla zwiększenia skali obecności inwestorów indywidualnych na rynku kapitałowym w Polsce.

Tomasz Orlik analizuje z kolei „Udział funduszy inwestycyjnych w oszczędnościach gospodarstw domowych w latach 2008-2018 w Polsce”. Podsumował on wykorzystanie funduszy w oszczędnościach gospodarstw domowych oraz małą popularność dobrowolnych programów emerytalnych w przeddzień wprowadzenia Pracowniczych Programów Kapitałowych (PPK). Wprowadzenie PPK będzie stymulowało, jego zdaniem, rozwój funduszy bezpośrednio poprzez przekazywanie składek oraz efekt synergii. Zakłada on również, że udział klientów w PPK przyczyni się do lepszego zrozumienia potrzeby i korzyści wynikających z długoterminowego oszczędzania.

Oczekiwania inwestorów indywidualnych wobec komunikacji prowadzonej przez emitentów publicznych emisji obligacji to przedmiot zainteresowania Kamila Gemry i Janusza Maruszewskiego w artykule pt. „Inwestorzy indywidualni wobec relacji inwestorskich emitentów obligacji”. Wyniki badania przeprowadzonego przez autorów na grupie 554 inwestorów pokazały, że głównym źródłem informacji dla inwestorów jest prospekt emisyjny lub memorandum informacyjne, oczekują oni także zabezpieczenia w formie hipoteki. Najważniejszym zaś czynnikiem decydującym o inwestycji jest oprocentowanie oraz czynniki, na które wpływa komunikacja emitentów, czyli historia spółki oraz wiarygodność zarządu.

Niniejszą publikację kończy artykuł Ireneusza Miciuły pt. „Globalny rozwój i perspektywy implementacji kryptowalut a stan tego rynku w Polsce". Omawia w nim funkcjonowanie i możliwe perspektywy rozwoju globalnego rynku kryptowalut i jego znaczenia dla gospodarek. Autor dokonuje również oceny stanu polskiego rynku kryptowalut na tle rozwoju tego rynku na świecie, co pozwala na ukazanie możliwych perspektyw rozwoju rynku kryptowalut w Polsce i na świecie.

Mamy nadzieję, że podobnie jak w przypadku poprzednich monografii, również ta stanie się inspiracją do pogłębionej refleksji naukowej w tematyce polskiego rynku kapitałowego, a oceny i wnioski wynikające $\mathrm{z}$ analiz zwartych w artykułach mogą służyć praktykom podejmującym decyzje inwestycyjne. Polski rynek kapitałowy oparty na trafnych regulacjach i zdrowych fundamen- 
tach ekonomicznych jest bardzo ważnym składnikiem rozwoju polskiej gospodarki.

Chcielibyśmy podziękować Autorom za trud poniesiony w przygotowaniu przedłożonej monografii, a wszystkim Recenzentom za wkład w podniesienie jej wartości naukowej i merytorycznej. 


\title{
Rozdział 1
}

\author{
TADEUSZ WINKLER-DREWS ${ }^{*}$
}

\section{Advanced Emerging Patchwork}

The present article assesses the economic and financial situation of nine markets (Brasil, Czech Republic, Grece, Hungary, Malesia, Mexico, South Africa, Thailand, Turkey), classified by the FTSE Classification of Markets as Advanced Emerging, between 2002 and 2016. The assessment of macroeconomic conditions was based on the analysis of inflation and GDP. In the context of the above findings, the structure and evolution of financial markets of the analyzed entities was analyzed. The condition of stock markets was assessed on the basis of stock indexes, value traded and volume of turnovers analysis.

Keywords: financial market, Stock Exchange, benchmark.

\section{Patchwark rynków wschodzących}

W artykule oceniono sytuację ekonomiczną i finansową dziewięciu rynków (Brazylia, Republika Czeska, Grecja, Węgry, Malezja, Meksyk, Republika Południowej Afryki, Tajlandia, Turcja), sklasyfikowanych przez FTSE Classification of Markets jako Advanced Emerging, w latach 2002-2016. Ocenę warunków makroekonomicznych oparto na analizie inflacji i PKB. W kontekście powyższych ustaleń przeanalizowano strukturę i ewolucję rynków finansowych analizowanych podmiotów. Stan rynków giełdowych oceniono na podstawie indeksów giełdowych, wartości transakcji i wielkości obrotów.

Słowa kluczowe: rynek finansowy, giełda papierów wartościowych, indeksy giełdowe.

JEL: G1

* dr hab., prof. ucz. Tadeusz Winkler-Drews - Department of Banking, Insurance and Risk, Kozminski University, Jagiellońska 57, 03-301 Warszawa, Poland; https://orcid.org/0000-00016500-369X. 


\section{Introduction}

After the year 2000 the global economy has been dominated by an unprecedented expansion in international trade and driven by technological advancement, which let companies create supply chains in multiple countries. Within the last 10 years about $60 \%$ of emerging economies grew faster than the US, but the geographical growth reach has decreased in the developing countries. The emerging markets still have room for development. Their productivity and capital per employee indices reach similar levels as in developed countries. The increasing productivity partially results from transferring employees from low-efficiency to high-efficiency sectors, and often in-between highly efficient sectors. The increasing productivity is the difference between short-term but transient catching up, and lasting progress towards high incomes. Developing countries were open to foreign investments and well-prepared when investors looked for higher profits than found in developed countries. Many developing countries saw an increase in their capital during rapid growth patches within the last two decades. A formal review of country classification within the FTSE global equity indices is conducted on an annual basis each September, using a comprehensive, transparent and consistent methodology. This annual review incorporates ongoing country classification research and classifies stock markets as Developed, Advanced Emerging, Secondary Emerging or Frontier within the FTSE global equity indices. The 2018 report $^{1}$ classifies the markets of Brazil, the Czech Republic, Greece, Hungary, Malaysia, Mexico, South Africa, Taiwan ${ }^{2}$, Thailand, and Turkey as Advanced Emerging markets.

\section{Brazil}

The Brazil's GDP is over $\$ 2$ billion, i.e. over $2.5 \%$ of the world GDP. If measured in purchasing power parity, the Brazil's GDP would increase to about $\$ 3.24$ billion, making it the eighth biggest economy in the world; however it is one of the most closed economies in the world. The trade volume between Brazil and the US represents only one sixth of the US trade volume with Mexico. Brazil is still deep in the social populism of its two former presidents from the Workers' Party (PT) - Luiz Inácio Lula da Silva (2003-2010) and his successor Dilma Rousseff (2011-2016). They managed to get millions of Brazilians out of extreme poverty. Increased consumption led to economic growth (Fig. 1), but

1 https://www.ftserussell.com/country-classification-historic-reviews? $\mathrm{ga}=2.220445848 .1013297193 .1569398237-1647391443.1569398237$.

2 Taiwan will not be included in the present analysis as it failed to provide the requested data. 
also to a higher budget deficit, higher public debt, inflation, the creation of more state-owned companies, and, as mentioned by the Wall Street Journal, the discovery of huge offshore oil fields in 2007 was an opportunity for growth that was wasted. During the 2015-2016 recession Brazil's GDP decreased by $8 \%$ (Fig. 1).

\section{F i g u r e 1. GDP and Brazil Inflation Rate, 2002-2017}

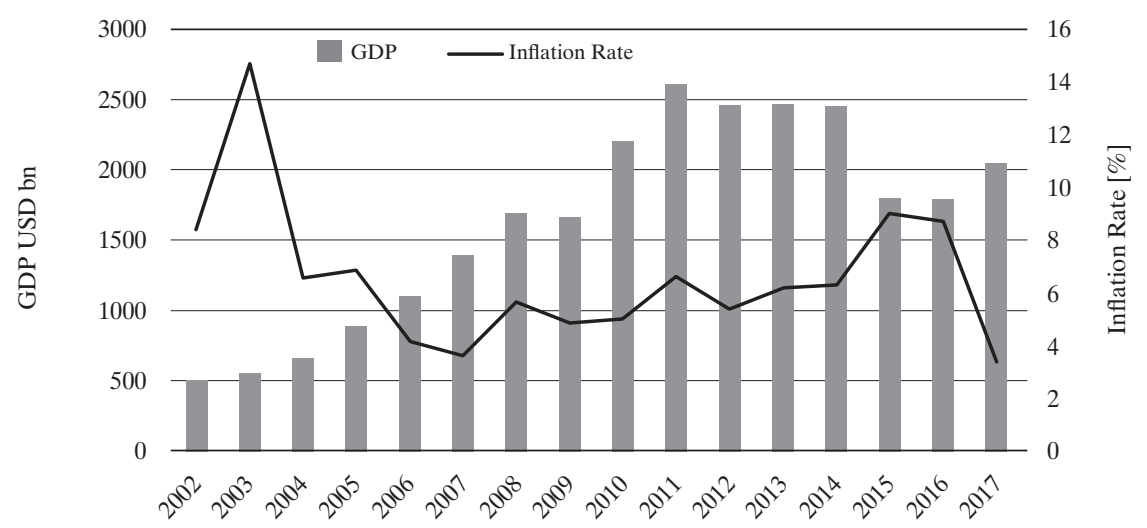

Source: Own study on the data.imf.org.

In 2017 Brazil's inflation rate was not very high (3.45\%) but the extreme poverty and a relatively high unemployment rate $(12 \%)$ remained an issue and caused economic stagnation. In 2017, the debt to GDP ratio averaged $75 \%$ (about 51\% in 2012). Poor use of the existing processing capacities and a decreasing value of loans given to businesses did not favor business investments. Between March and July 2017 the Brazilian government paid out about 10 million people from the Guarantee Fund for Length of Service (FGTS), the equivalent of $0.7 \%$ of GDP, to boost economic growth. The fund saved $8 \%$ of the worker's earnings monthly, on special individual accounts, to support them in case of specific eventualities. The payments were made in an accelerated mode, i.e. within three years after contract termination. Brazil's fiscal situation still wasn't good; the budget deficit was high. Interest rates were lowered to support investments and consumption. Those rates on subsidized loans, given by the Brazilian development bank BNDES, started being determined differently. Until 2017, the interest rate on these loans were determined confidentially by the government, which put pressure on the public finances and led to inadequate resource allocation. Since January 2018, loan interest rates are determined basing on the profitability of five-year government bonds. The financial markets seem to believe in Brazil's capacity to conduct the necessary reforms, which is 
reflected in the increasing trend of Bovespa (Fig. 5), a relatively strong, real, and low profitability government bonds. Figure 2 presents the Brazil's structure of the financial market in relation to GDP, ratio during the analyzed period.

F i g u r e 2. Brazil's structure financial market ratio to GDP, 2002-2016

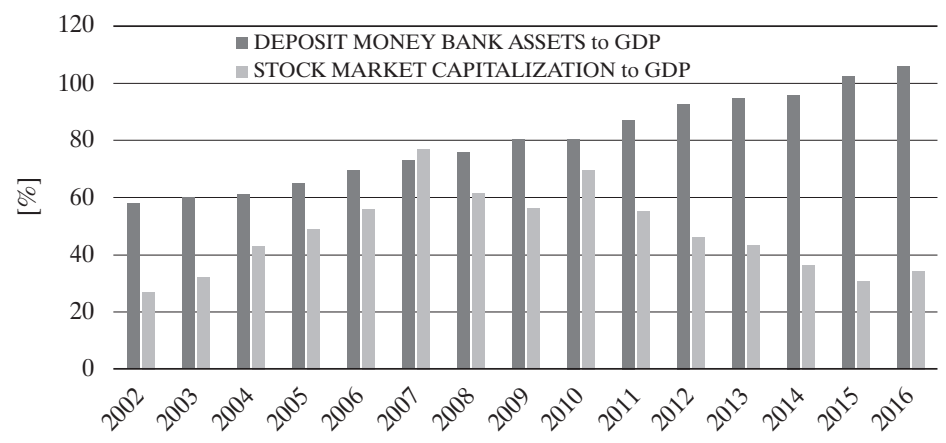

Source: Own study on the data.imf.org.

The Brazil's stock market is definitely less developed than the banking sector. In the years 2002-2007 trends of both parameters are coincident. Then, in the years 2008-2016 trends of both parameters are opposites. The correlation coefficient over the period analyzed is -0.13 . Average of Deposit Money Bank Assets to GDP of Brazil is $80.1 \%$; average of Stock Market Capitalization to $G D P$ of Brazil is $47.82 \%$. Figure 3 presents the Stock Market Total Value Traded to $G D P$ ratios for Brazil and the US within the period under analysis.

F ig u r e 3. Stock Market Total Value Traded to GDP ratio for Brazil and the US, 2002-2016

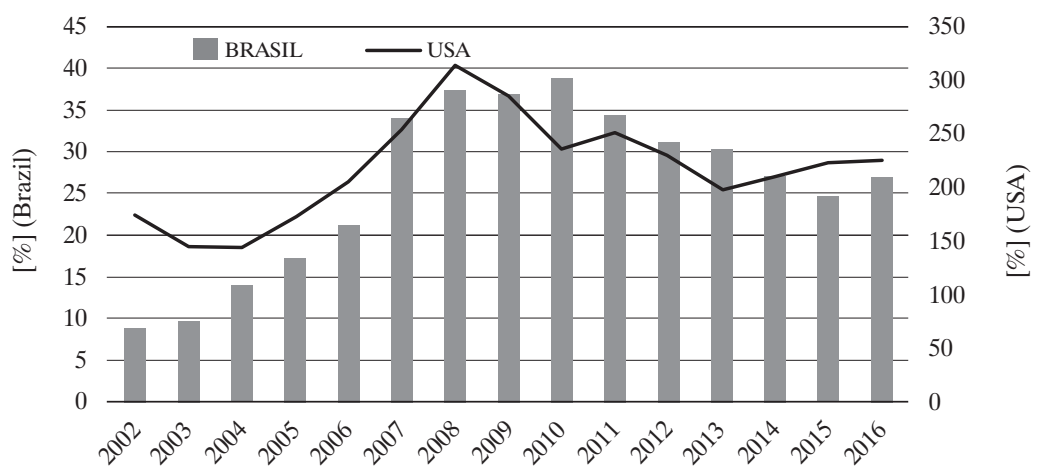

Source: Own study on the data.imf.org. 
The trends of both parameters are coincides. The correlation coefficient between both parameters within the period analyzed is 0.88. Average of Stock Market Total Value Traded to GDP of Brazil is 26.18\%; US' Average of Stock Market Total Value Traded to GDP is $217.76 \%$. Figure 4 presents the Stock Market Turnover Ratio to GDP for Brazil and the US within the analyzed period.

\section{F i g u r e 4. Stock Market Turnover Ratio to GDP of Brazil and the US, 2002-2016}

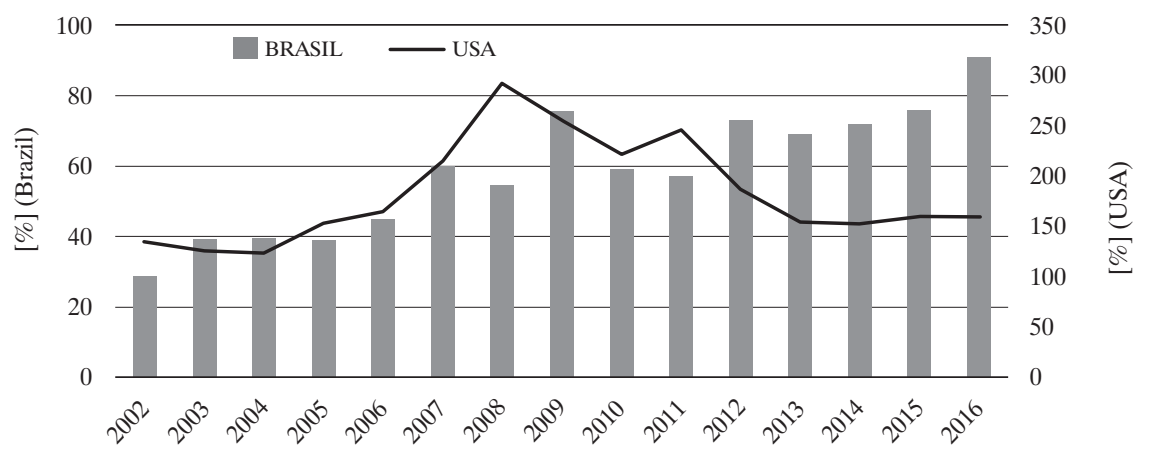

Source: Own study on the data.imf.org.

In the period 2002-2010, trends of both parameters are coincides. In the period 2011-2016 trends of both parameters are opposites. The correlation coefficient between both parameters in the analyzed period is 0.27 . Average of Stock Market Turnover Ratio to GDP of Brazil is 58.64\%; US average of Stock Market Turnover Ratio to GDP is $183.43 \%$. Figure 5 presents the Brazil Stock Exchange benchmark values within the analyzed period:

F ig u r e 5. BOVESPA Index values, 2002-2017

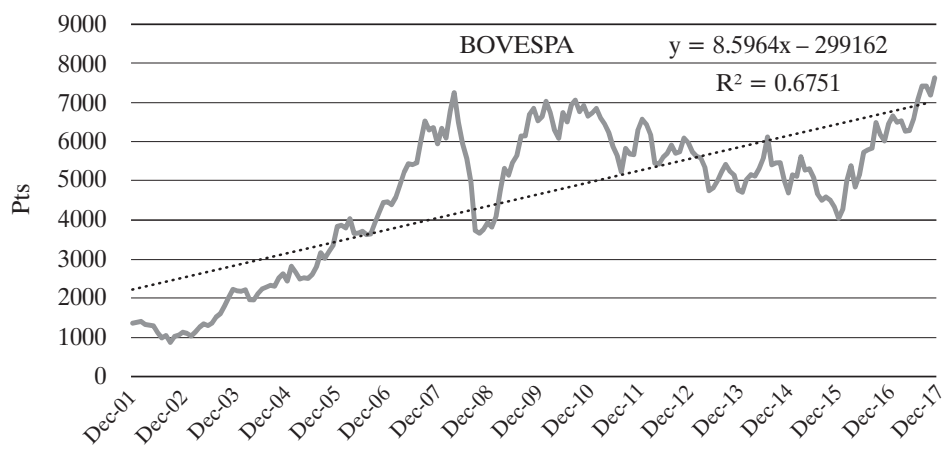

Source: Own study on the Stooq.pl. 
The correlation coefficient value between BOVESPA Index and Brazil Stock Market Capitalization to GDP is $81.66 \%$. The correlation coefficient value between BOVESPA Index and Brazil Stock Market Total Value Traded to GDP is $80,51 \%$. The correlation coefficient value between BOVESPA Index and Brazil Stock Market Turnover Ratio to GDP is $75.78 \%$.

\section{The Czech Republic}

In 2003, before joining the EU, the Czech revenue from exports was $\$ 54$ billion. Joining the EU in 2004 boosted the growth until 2008 (the GDP grew by $20 \%$ annually) (Fig. 6).

F i g u re 6. GDP and Czech Republic Inflation Rate, 2002-2017

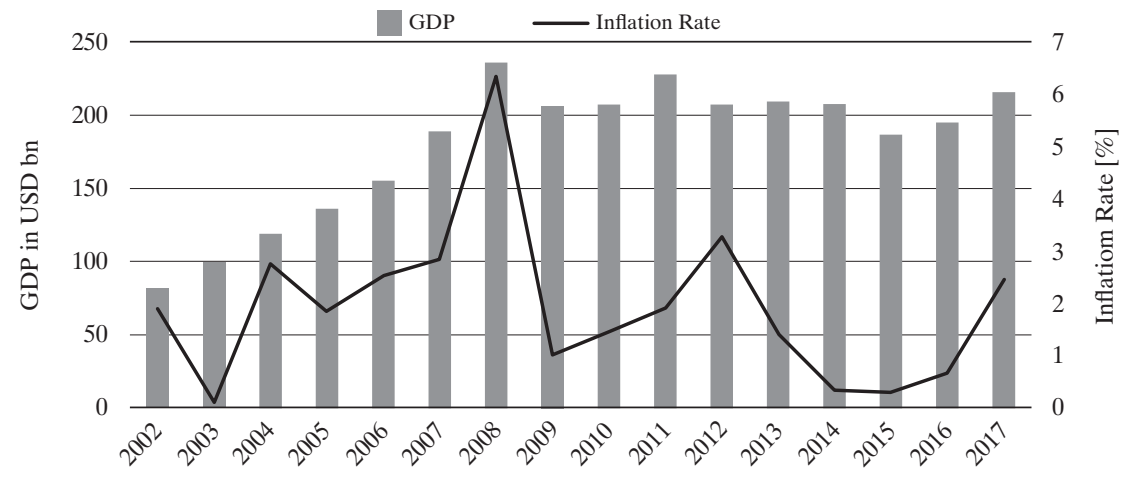

Source: Own study on the data.imf.org.

Car and car part manufacturing represents as much as $10 \%$ of the country's GDP and $20 \%$ of the production. The subprime crisis led to a decrease in manufacturing between 2009 and 2010, mainly because of the crisis in the automotive sector. Between 2011 and 2013, the Czech economy was getting weaker as a result of low internal demand, caused by lower household and business expenses under the influence of a savings policy implemented by both the Czech Republic and the eurozone countries constantly facing debt issues. The year 2015 saw the most dynamic growth in eight years, which led to an increase in household expenses (2.9\%) and in investments (9.6\%). In 2016 
and 2017 the Czech Republic had budgetary surplus. The production of most industries was increasing, especially in the automotive and electric sectors. The sharp growth stemmed from foreign and domestic demand. The Czech GDP calculated in purchasing power increased by $25 \%$ since 2004 ; however the GDP PPS per capita increased by $80 \%$. In 2017 the budget deficit was only $1.5 \%$ of GDP; the public debt was $34.6 \%$ of GDP; the GDP per capita, in the terms of average power parity, was $85 \%$ of that in the whole eurozone. The unemployment rate in the Czech Republic is low, and so it the raise of average wages; as a consequence debt remains important, pensions are low, and home prices are sky-rocketing. Figure 7 presents the Czech Republic's structure of the financial market in relation to GDP ratio within the period analyzed.

\section{F ig u r e 7. Czech Republic's structure financial markets ratio to GDP, 2002-2016}

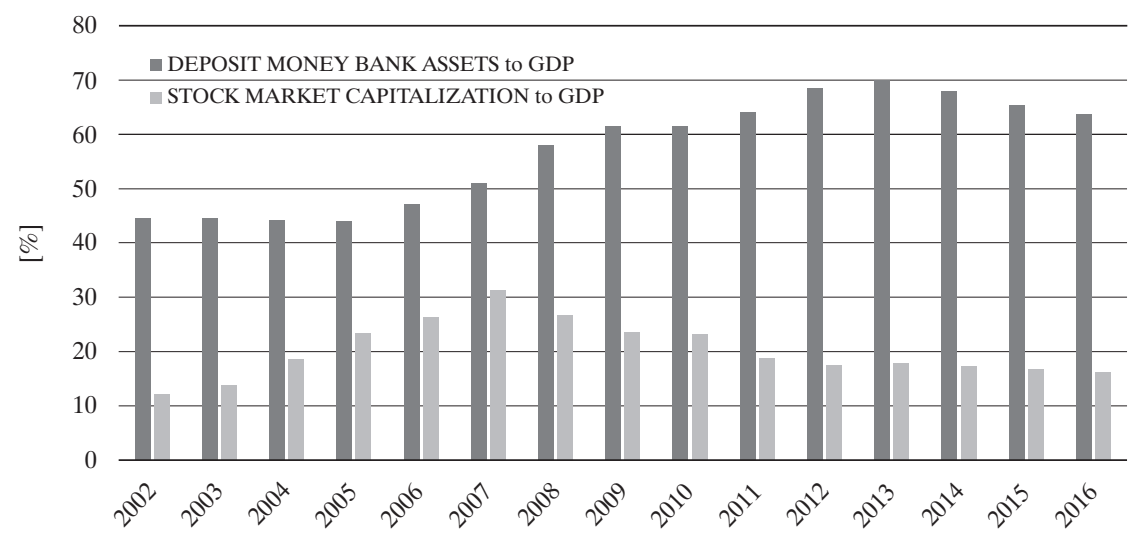

Source: Own study on the data.imf.org.

The Czech Republic's stock market is definitely less developed than the banking sector. In the years 2002-2007 trends of both parameters are coincides. In the years 2008-2016 trends of both parameters are opposites. The correlation coefficient in the analyzed period is -0.12 . Average of Deposit Money Bank Assets to GDP of Czech Republic is 57.12\%; average of Stock Market Capitalization to GDP of Czech Republic is $20.26 \%$. Figure 8. presents the Stock Market Total Value Traded to GDP ratios for Czech Republic and the US within the analyzed period. 


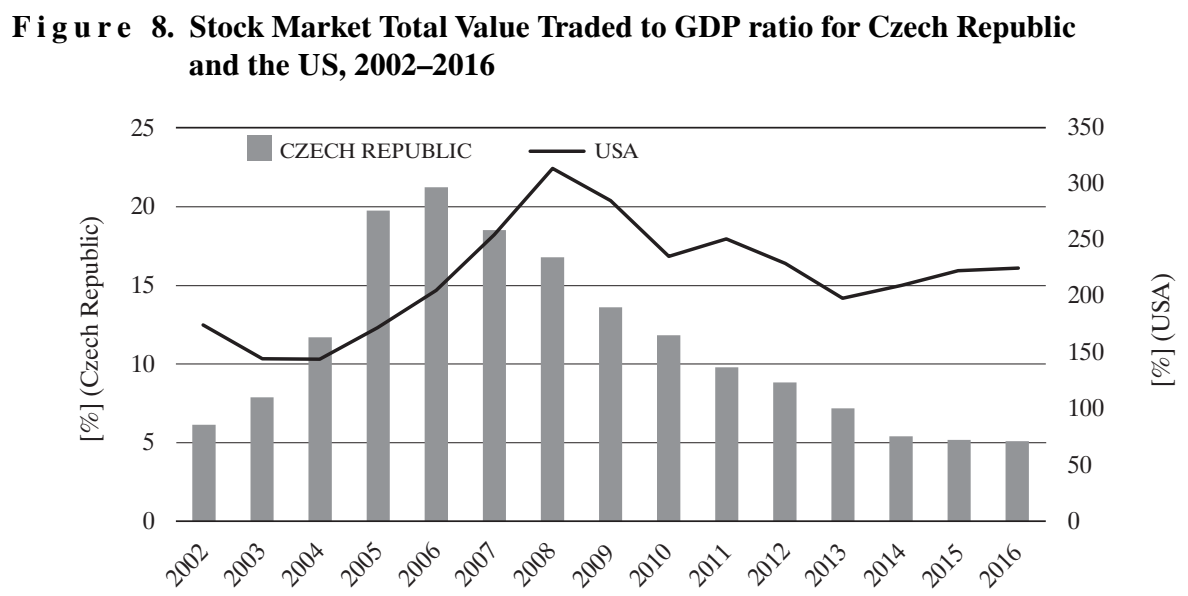

Source: Own study on the data.imf.org.

In the periods 2002-2003 and 2013-2016, trends of both parameters are opposites. In the period 2004-2012 trends of both parameters are coincides. The correlation coefficient between both parameters in the analyzed period is: 0.23. Average of Stock Market Total Value Traded to GDP of Czech Republic is 11.76\%. Figure 9 presents the Stock Market Turnover Ratio to GDP for Czech Republic and the US within the analyzed period.

F i g u r e 9. Stock Market Turnover Ratio to GDP of Czech Republic and the US, 2002-2016

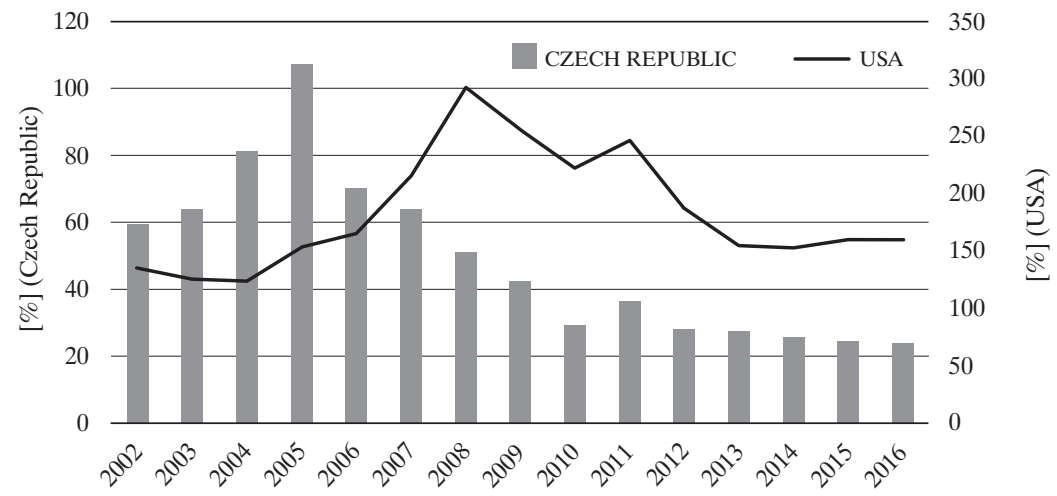

Source: Own study on the data.imf.org. 
In the periods 2002-2003 and 206-2008, the trends of both parameters are opposites. In the periods 2004-2005 and 2009-2016, the trends of both parameters are coincides. The correlation coefficient between both parameters in the analyzed period is -0.24 . Average of Stock Market Turnover Ratio to GDP of Czech Republic is $49.02 \%$. Figure 10 presents the Prague Stock Exchange benchmark values within the analyzed period.

F ig u r e 10. PX Index values, 2002-2017

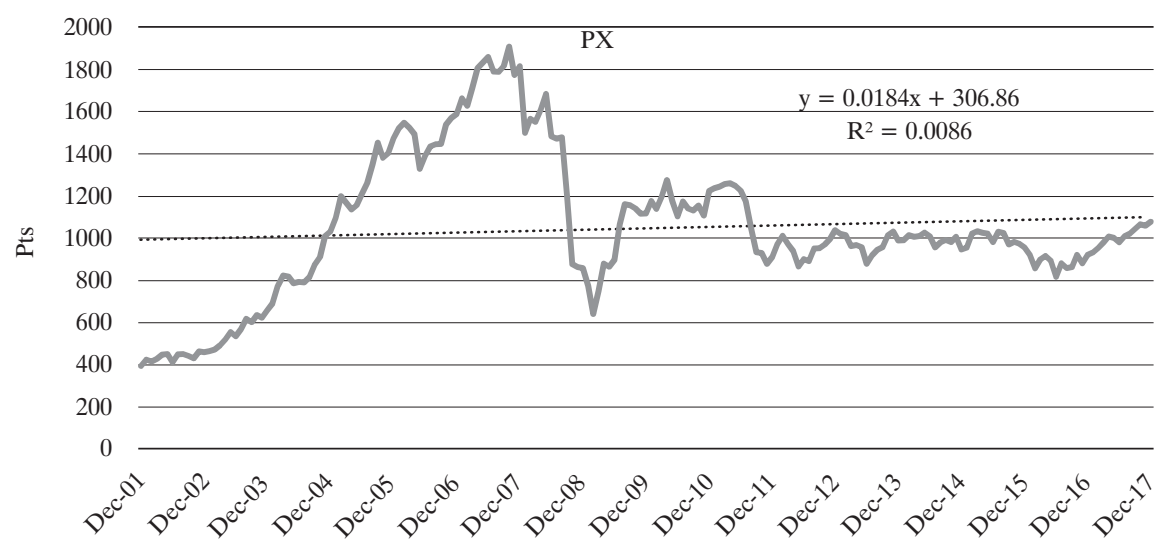

Source: Own study on the Stooq.pl.

The correlation coefficient value between $P X$ Index and the Czech Stock Market Capitalization to GDP is $56.41 \%$. The Correlation coefficient value between PX Index and Czech Stock Market Total Value Traded to GDP is $68.12 \%$. The correlation coefficient value between PX Index and Czech Stock Market Turnover Ratio to GDP is $64.19 \%$.

\section{Greece}

Between 1995 and 2013 there was only one year in which Greece's budgetary deficit was lower than 5\% of GDP. That was in the year 2000, when the debt accounted for $4.1 \%$ of GDP. The Greek GDP grew until 2008 (Fig. 11). 
F i g u re 11. GDP and Greece Inflation Rate, 2002-2017

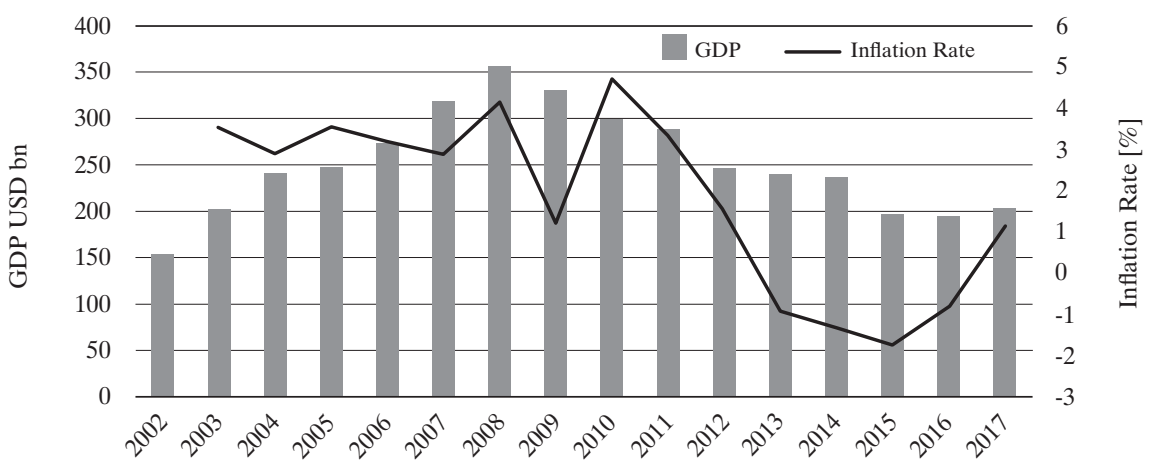

Source: Own study on the data.imf.org.

For many years the government didn't do much to maintain an economic and financial balance, and even went as far as to hide negative facts. Furthermore, by joining the eurozone, Greece no longer had the possibility to react (using interest and exchange rates) to future crises; it could only resort to fiscal policy measures, i.e. taxes and budgetary deficit. For an unbalanced economy with an increasing public debt, including foreign, the crisis resulted from external factors: a global economic and financial crisis. Drastic measures were undertaken when the crisis started, however, they turned out to be insufficiently effective and failed to stimulate the economic growth. They were mainly aimed at preventing insolvency. For years Greece, with the help of Goldman Sachs, showed untrue economic and financial data, which in 2010 and 2011 sparkled a debate whether Greece shouldn't have left the eurozone, and led to negative reactions in the financial markets. In order to be able to go back to financing its private debt, a subsequent reduction of the public debt is necessary. Unlike the first two financial assistance programs, the third one has been relatively successful. Since 2015 Greece has been meeting most of its loan constraints. There is again a budgetary surplus in the primary budget balance and the economy has picked up. That was confirmed by the Eurogroup, which suggested certain potential measures aiming at writing debts off:

- early International Monetary Fund (IMF) debt payment through a cheaper financing with the European Stability Mechanism (ESM),

- extending the maturity dates and postponing the interest payment on the $€ 131$ billion loan received by Greece from the European Financial Stability Facility, Greece's biggest public creditor. 
The European Commission (EC; 2018) and the IMF agreed in their reports (2018 and 2017 respectively) that Greece failed to make its loan repayments. However, they disagree about how significant the debt reduction should be and how it should be carried out.

The EC accepted the 2009 Laubach-based interest rate model (private creditors calculate bonuses for risk rated as three basis points, i.e. $0.03 \%$, for every additional per cent over the limit of the public debt in the amount of $60 \%$ of GDP). Basing on debt ratio from the end of 2017, the credit spread equalled 380 basis points (the actual 10 -year government bond spread was about 355 basis points at the beginning of March 2018). The debt isn't currently stable; one of the reasons for that is the fact that paying it requires a large participation of public investors at a time when both the debt level and private creditors' spreads remain high. Figure 12 presents the Greece's structure of the financial market in relation to GDP ratio within the analyzed period.

\section{F ig u r e 12. Greece's structure financial markets ratio to GDP, 2002-2016}

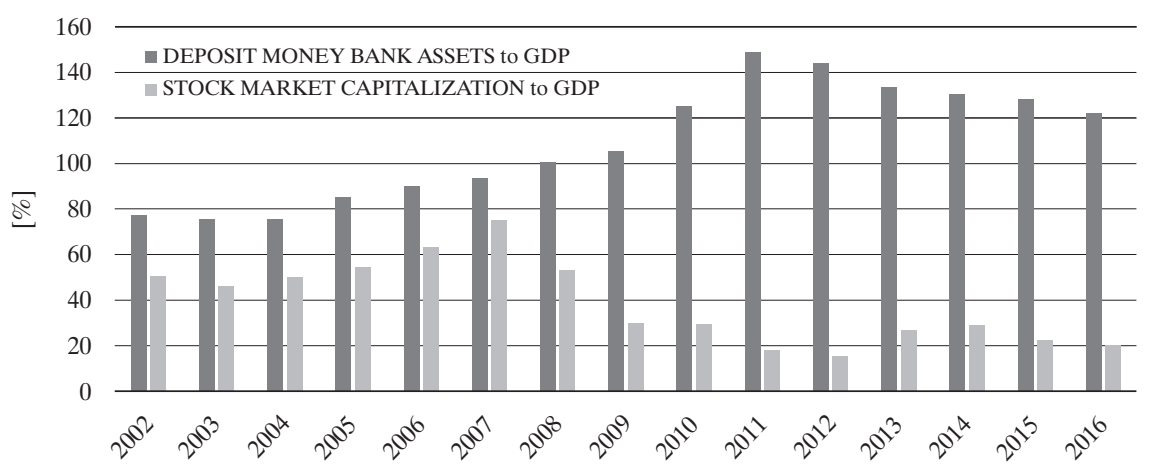

Source: Own study on the data.imf.org.

The Greece's stock market is definitely less developed than the banking sector. In the period 2002-2007 trends of both parameters are coincides. In the years 2008-2016 trends of both parameters are opposites. The correlation coefficient in the analyzed period is -0.81 . Average of Deposit Money Bank Assets to GDP of Greece is $109.14 \%$; average of Stock Market Capitalization to GDP of Greece is $39.03 \%$. Figure 13 presents the Stock Market Total Value Traded to GDP ratios for Greece and the US within the analyzed period. 
F i g u r e 13. Stock Market Total Value Traded to GDP ratio for Greece and the US, 2002-2016

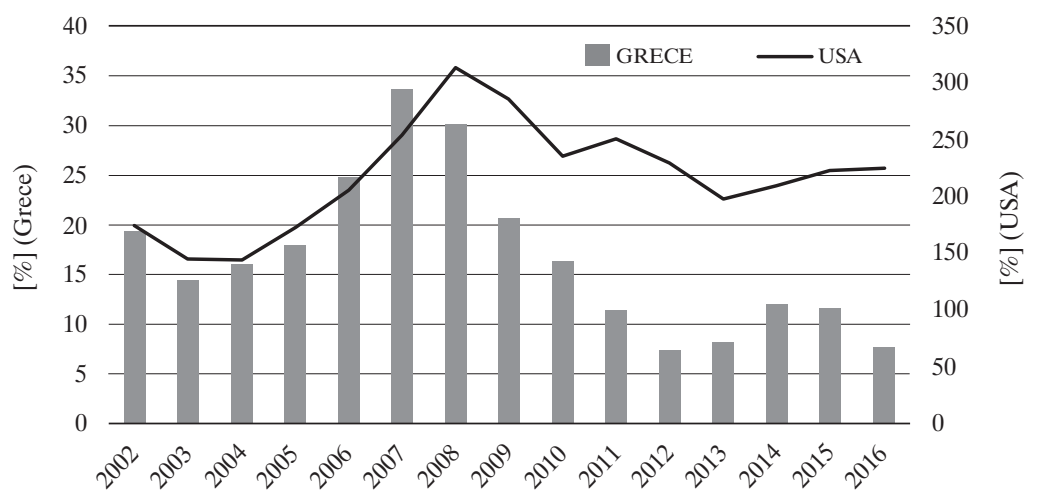

Source: Own study on the data.imf.org.

In the period 2002-2010 the trends of both parameters are coincides. In the period 2011-2016 the trends of both parameters are opposites. The correlation coefficient between both parameters in the analyzed period is 0.37 . Average of Stock Market Total Value Traded to GDP of Greece is $16.79 \%$. Figure 14 presents the Stock Market Turnover Ratio to GDP for Greece and the US within the analyzed period.

F i g u r e 14. Stock Market Turnover Ratio to GDP of Greece and the US, 2002-2016

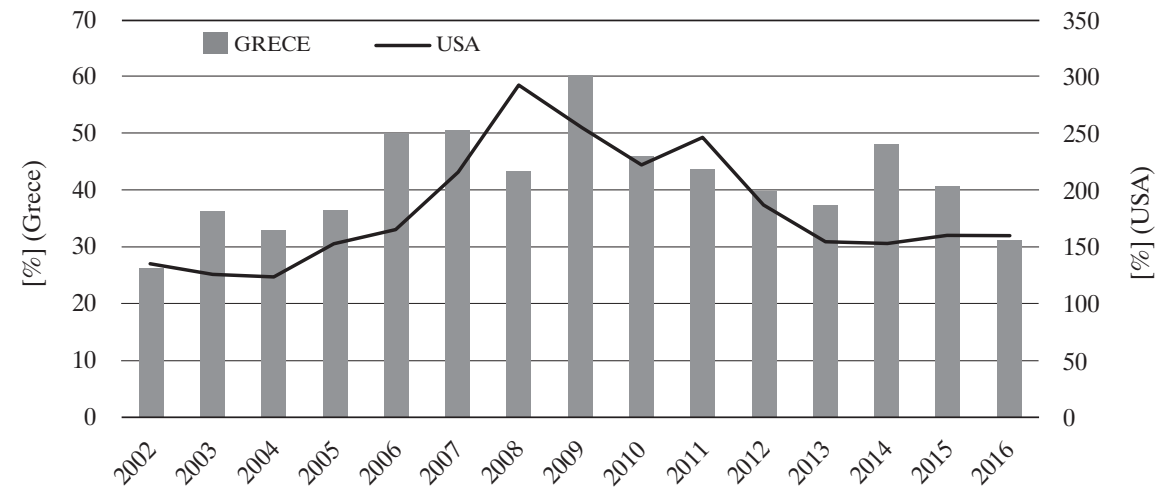

Source: Own study on the data.imf.org. 
In the periods 2002-2007 and 2011-2014 the trends of both parameters are coincides. In the periods 2008-2010 and 2013-2016 the trends of both parameters are opposites. The correlation coefficient between both parameters in the analyzed period is 0.62. Average of Stock Market Turnover Ratio to GDP of Greece is $41.53 \%$. Figure 15 presents the Athex Stock Exchange benchmark values within the analyzed period.

\section{F i g u r e 15. ATHEX Index Values, 2002-2017}

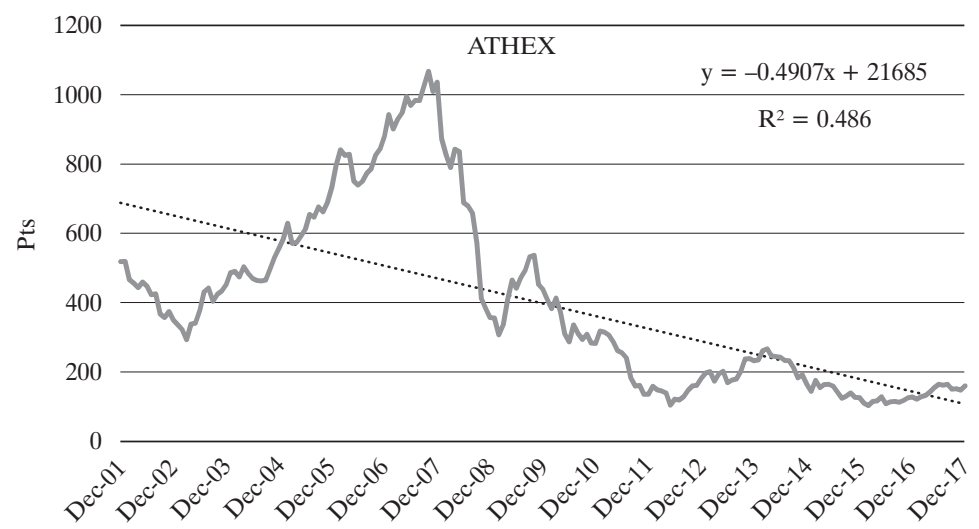

Source: Own study on the www.Stooq.pl.

The correlation coefficient value between ATHEX Index and Greece Stock Market Capitalization to GDP is $86.86 \%$. The correlation coefficient value between ATHEX Index and Greece Stock Market Total Value Traded to GDP is $65.55 \%$. The correlation coefficient value between ATHEX Index and Greece Stock Market Turnover Ratio to GDP is $33.03 \%$.

\section{Hungary}

Since joining the EU in 2004, Hungary has been attracting foreign investors, despite having high taxes and a bloated public sector (in 2014 the public debt oscillated at $80 \%$ of GDP). It solves budget holes by increasing taxes. Between 2007 and 2013, Hungary was under permanent stagnation (the GDP only regained its 2007 value of $\$ 140$ billion in 2014 (Fig. 16)). 
F i g u re 16. GDP and Hungary Inflation Rate, 2002-2017

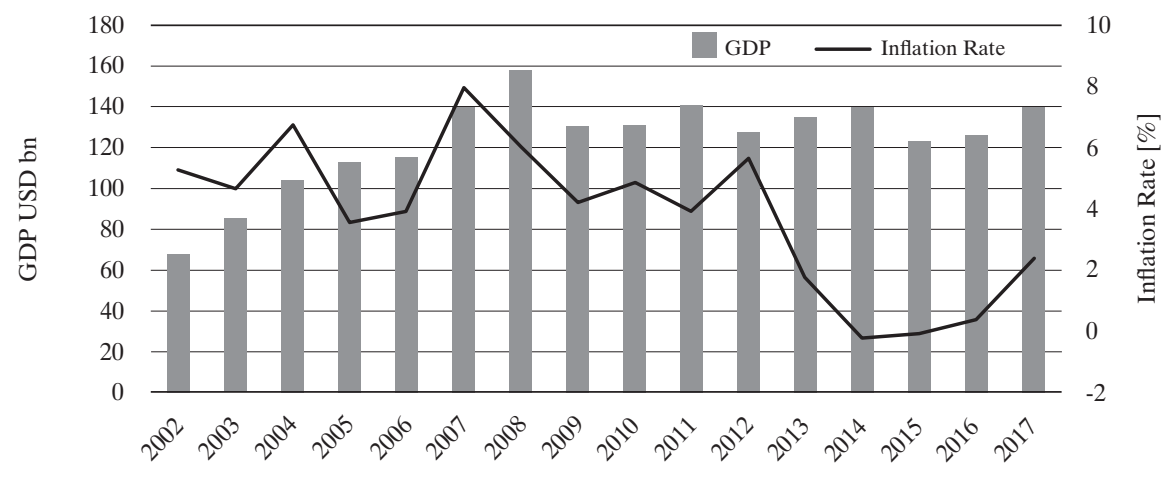

Source: Own study on the data.imf.org.

The fiscal consolidation observed in the statistics results from a drastic reform of the pension sector, i.e. the suppression of pension funds. The government's claim that the private sector was left too much room in the previous years, and its announcement that public-utility companies, that had been privatized by previous governments, would be re-nationalized, do not develop market mechanisms The government tries to actively regulate the situation on different markets by increasing its control over prices. The reluctance towards foreign capital and the policy of opening to the East (keleti nytitás), i.e. on Russia, China, Kazakhstan, and Azerbaijan, promoted by the government, have not really brought the expected effects (in 2015 GDP decreased to $\$ 123$ billion). The government attempts to solve any economic problems by creating money. The Hungarian central bank runs a program of cheap loans for banks which then offer new loans to Hungarian businesses. Until 2015 the equivalent of over $9 \%$ of the Hungarian GDP had been loaned. Since becoming the prime minister in 2010, Viktor Orbán has been consequently industrializing the country. However, narrow specialization of the Hungarian foreign trade, consisting mainly of huge automotive manufacturing factories (Mercedes, Audi, Suzuki, and Opel) and the thwarting investments are not what would drive the economy. In 2016 the GDP increased by $2.41 \%$. In 2017 it had reached $\$ 140$ billion (11\% increase) for the third time. The industry was at its peak since the PMI 
started being calculated for Hungary 20 years ago (59.5/100 pts in February 2017). It's an increased demand for services and a developing construction and automotive sectors that led to the growth. The dynamic salary and consumption increase in Hungary have been fueling the economic growth. The economy is thriving with the salary increase, however highly qualified employees are missing. The increasing internal demand generates an inflation that destroys competitiveness, limiting export opportunities. Since 2015 the stock exchange market has grown dynamically (Fig. 20) and has become an even better place to invest. Figure 17 presents the Hungary's structure of the financial market in relation to GDP ratio within the analyzed period.

\section{F ig u re 17. Hungary's structure financial market ratio to GDP, 2002-2016}

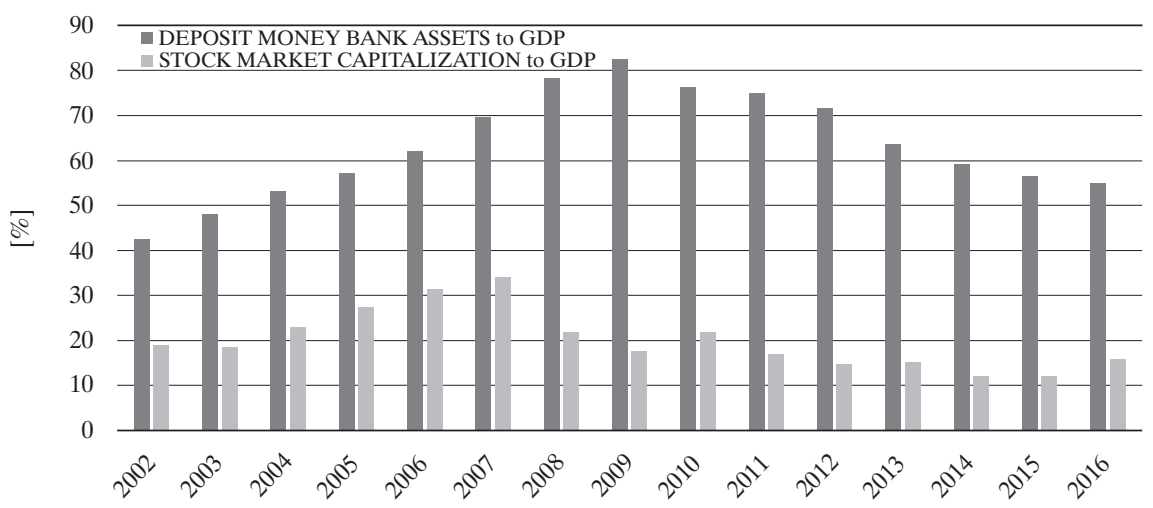

Source: Own study on the data.imf.org.

The Hungary's stock market is definitely less developed than the banking sector. In the period 2002-2007 trends of both parameters are coincides. In the period 2008-2016 trends of both parameters are opposites. The correlation coefficient in the analyzed period is 0.08. Average of Deposit Money Bank Assets to GDP of Hungary is $63.47 \%$; average of Stock Market Capitalization to GDP of Hungary is $20.16 \%$. Figure 18 presents the Stock Market Total Value Traded to GDP ratios for Hungary and the US within the analyzed period. 
F i g u r e 18. Stock Market Total Value Traded to GDP ratio for Hungary and the US, 2002-2016

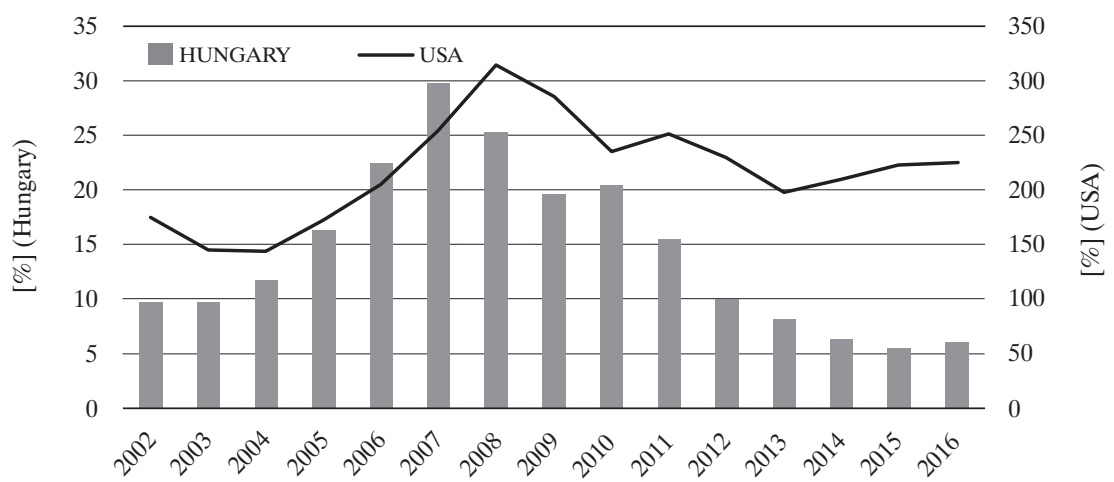

Source: Own study on the data.imf.org.

In the period 2002-2010 the trends of both parameters are coincides. In the period 2011-2016 trends of both parameters are opposites. The correlation coefficient in the analyzed period is 0.53 . Average of Stock Market Total Value Traded to GDP of Hungary is $14.41 \%$. Figure 19 presents the Stock Market Turnover Ratio to GDP for Hungary and the US within the analyzed period.

F i g u r e 19. Stock Market Turnover Ratio to GDP of Hungary and the US, 2002-2016

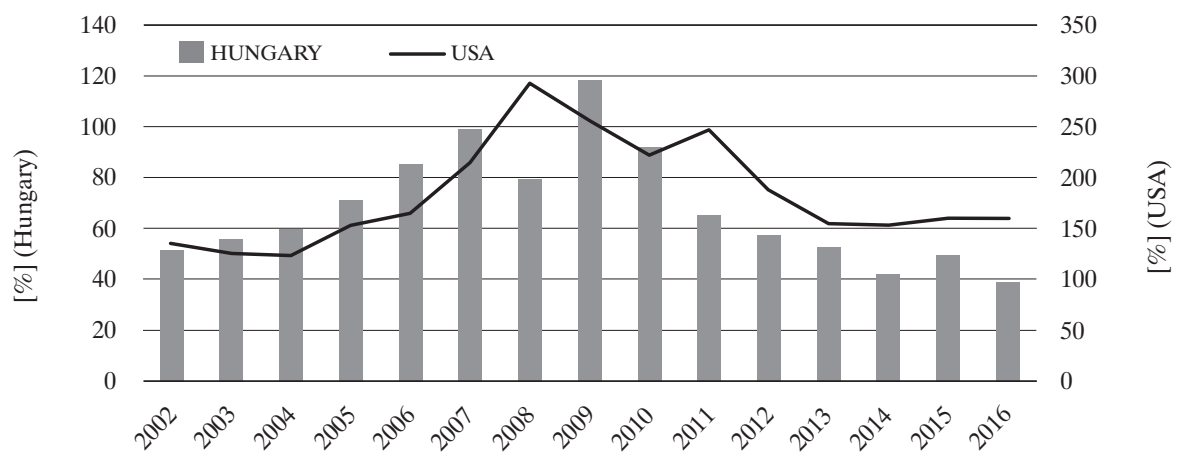

Source: Own study on the data.imf.org.

In the period 2002-2016 the trends of both parameters are coincides. The correlation coefficient in the analyzed period is 0.65. Average of Stock Market Turnover Ratio to GDP of Hungary is $67.96 \%$. Figure 20 presents the Budapest Stock Exchange benchmark values within the analyzed period. 
Fig u re 20. BUX Index Values, 2002-2017

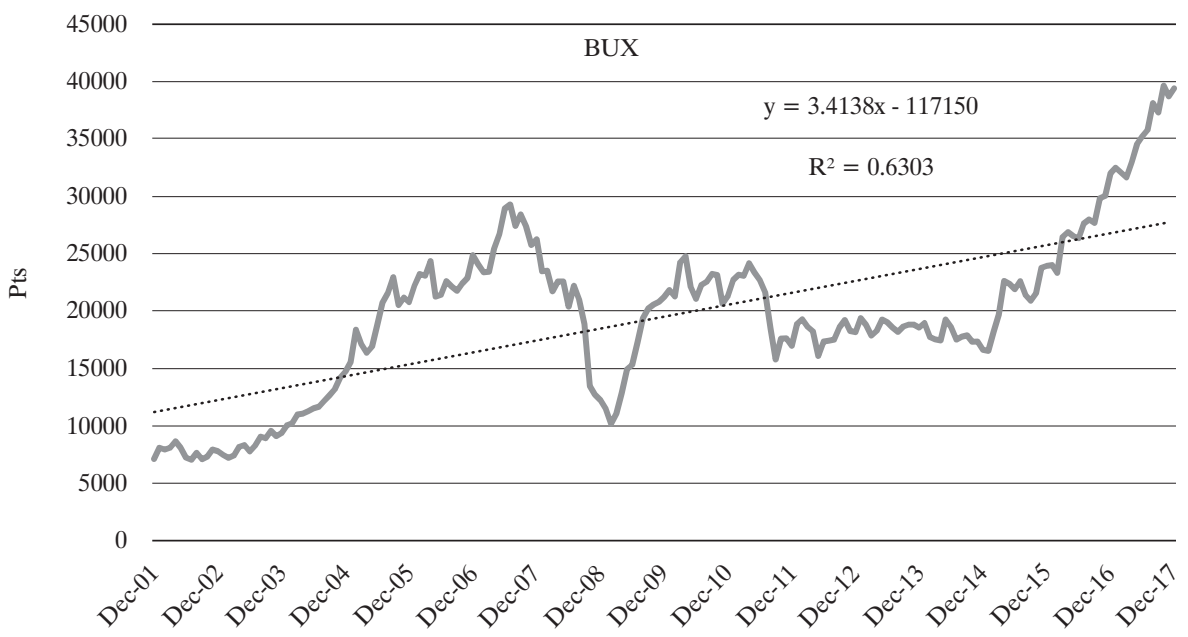

Source: Own study on the www.Stooq.pl.

The correlation coefficient value between $B U X$ Index and Hungary Stock Market Capitalization to GDP is $37.48 \%$ The correlation coefficient value between BUX Index and Hungary Stock Market Total Value Traded to GDP is $17.5 \%$ The correlation coefficient value between $B U X$ Index and Hungary Stock Market Turnover Ratio to GDP is $28,2 \%$.

\section{Malaysia}

Malaysia is one of the most developed countries in South-East Asia, facing the challenges of the middle income trap. The transformation from a rural to an industrial country ended in 1998. Between 1981 and 2003 the prime minister Mahathir Mohammad carried out reforms that combined the rules of Islam and the prerequisites of economic growth. The exploitation of offshore oil fields by Petronas, a state-owned concern, and therefore a low petrol price, and the production of palm oil (at the expense of rainforest logging) and natural rubber, played a big role in that change. For many years Malaysia has been trying to put emphasis on the development of the processing industry and of advanced technology, however Malaysian companies are more prone to innovate in the services sector (supply and marketing). The share of the processing industry in the GDP has been increasing successfully, but consumption has the biggest part in the GDP increase (Fig. 21). 
F i g u re 21. GDP and Malesia Inflation Rate, 2002-2017

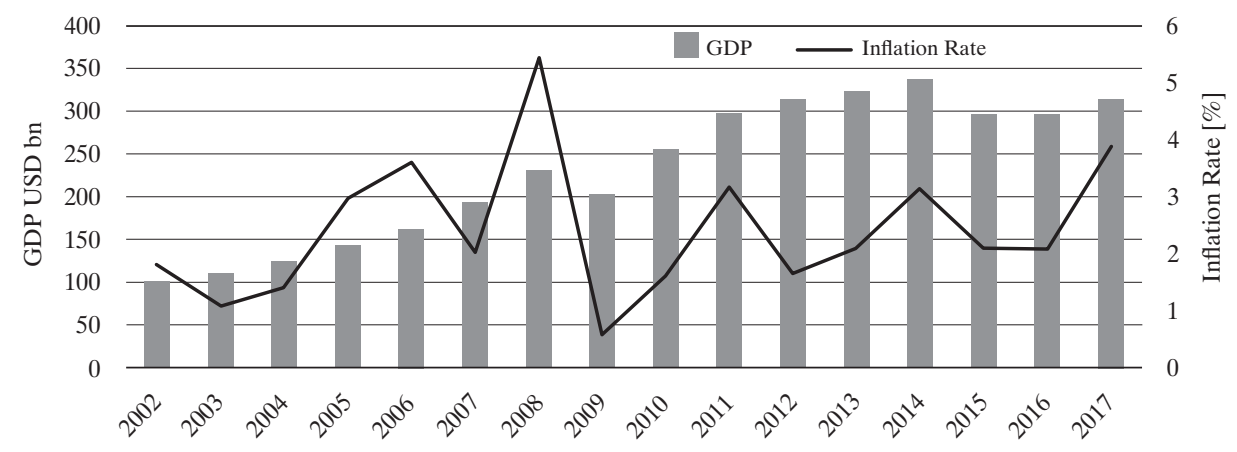

Source: Own study on the www.data.imf.org.

However, the World Bank lowered its growth forecast for Malaysia, because of a low investment rate and of a decrease in public expenses. The Malaysian economic growth has been very stable. Since 2010 the GDP increases annually by $5.5 \%$, while inflation remains symbolic and unemployment is lower than $3 \%$. The fiscal deficit is at a similar level as the GDP. The industry is the main source of export income in Malaysia. The national automotive industry, annually manufacturing over half a million cars (Proton and Perodua), is of crucial importance. It is currently better integrated with global supply chains than with the national economy because of foreign investments. However, these actions have limited consequences despite top-down programs and innovation investments (1.3\% of GDP). There is no integration between the programs and the institutions responsible for scientific and technical progress. The creation of the MAD business incubator, the biggest private entity of this kind within the ASEAN countries, was a big success. The Silicon Valley could not become reality, because of the limited number of specialists and highly-qualified employees (the best choose to work in Singapore). Malaysia attracts poorly qualified immigrants working in the processing industry and construction sectors. The quality of higher-education is mediocre, because of ethnical quotas (65\% of the students must be Malay); the same holds true for university teaching staff and administration. Malaysia has all what it takes to become a digital economy, not losing sight of its role model - Singapore. In 2016 Malaysia has become the first country in the world to implement a Digi- 
tal Free Trade Zone, aiming at increasing the e-commerce turnover to $\$ 48$ billion and growth to the level of $17 \%$ of GDP generated from the sales of ICT products and services. If that works out, productivity should grow at a rate of 2.3\% annually, as assumed by the Malaysia economic plan for 2016-2020, since Malaysia is to a large extent a planned economy. There are, however, certain limitations. Not more than $50 \%$ of small and medium-sized businesses have access to broadband internet (partially because of high rates applied by Telekom Malaysia, the monopolist in that market); there is no ecosystem that would integrate various elements of the digital economy and its infrastructure, thus engaging more private capital and investors who should not be replaced by the state. Figure 22 presents the Malaysian's structure of the financial market in relation to GDP ratio within the analyzed period.

\section{F i g u r e 22. Malaysian's structure financial market ratio to GDP, 2002-2016}

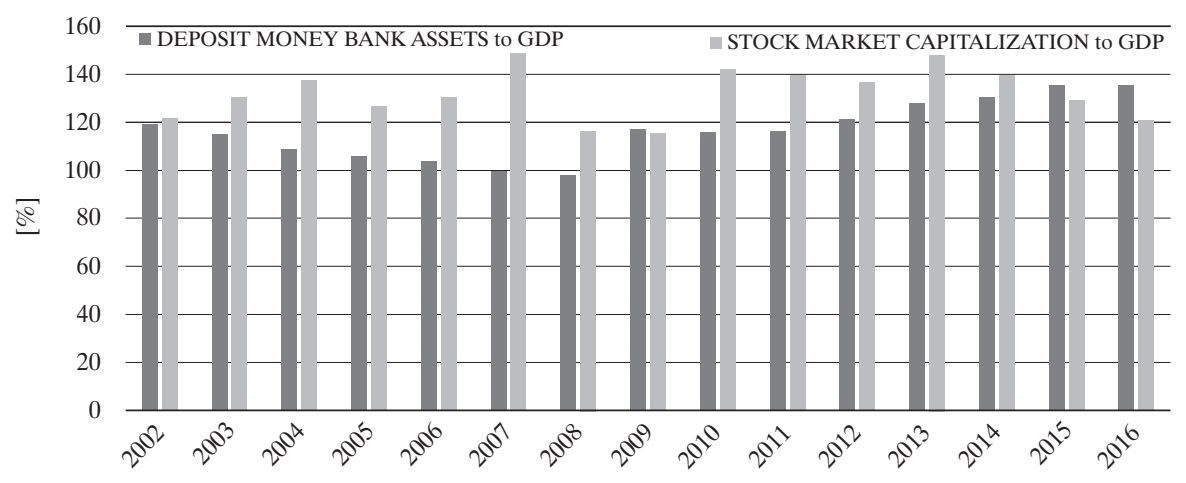

Source: Own study on the www.data.imf.org.

The Malaysia Stock Exchange is less developed than the banking sector. In the analyzed period, the trends of both parameters are weakly correlated. The correlation coefficient in the analyzed period is 0.02. Average of Deposit Money Bank Assets to GDP of Malaysia is $116.59 \%$; average of Stock Market Capitalization to GDP of Malaysia is $132.06 \%$. Figure 23 presents the Stock Market Total Value Traded to GDP ratios for Malaysia and the US within the analyzed period. 
F i g u r e 23. Stock Market Total Value Traded to GDP ratio for Malaysia and the US, 2002-2016

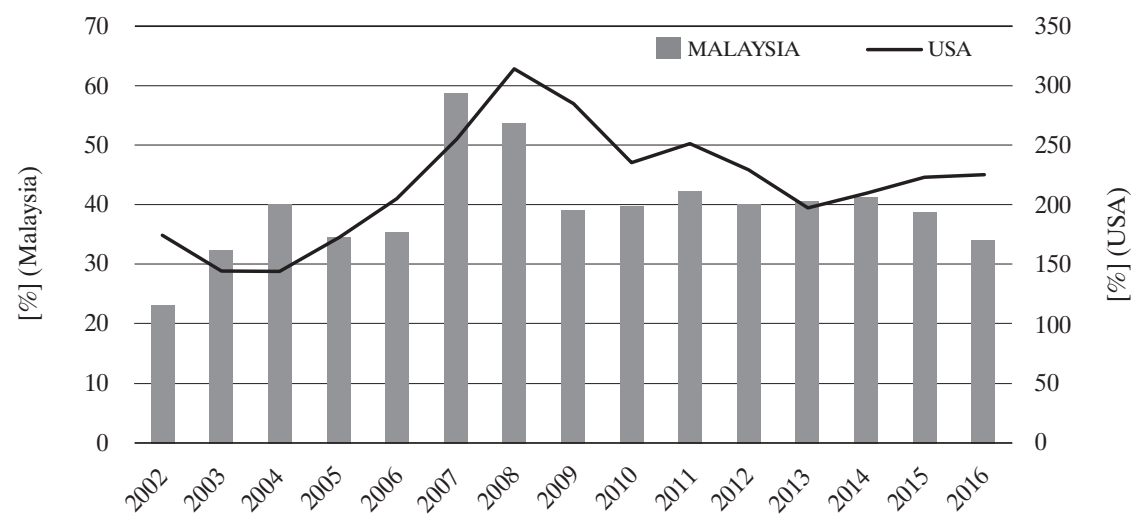

Source: Own study on the www.data.imf.org.

In the period 2002-2013 the trends of both parameters are coincides. In the period 2012-2016 trends of both parameters are opposites. The correlation coefficient in the analyzed period is 0.63. Average of Stock Market Total Value Traded to GDP of Malaysia is $39.64 \%$. Figure 24 presents the Stock Market Turnover Ratio to GDP for Malaysia and the US within the analyzed period.

F i g u r e 24. Stock Market Turnover Ratio to GDP of Malaysia and the US, 2002-2016

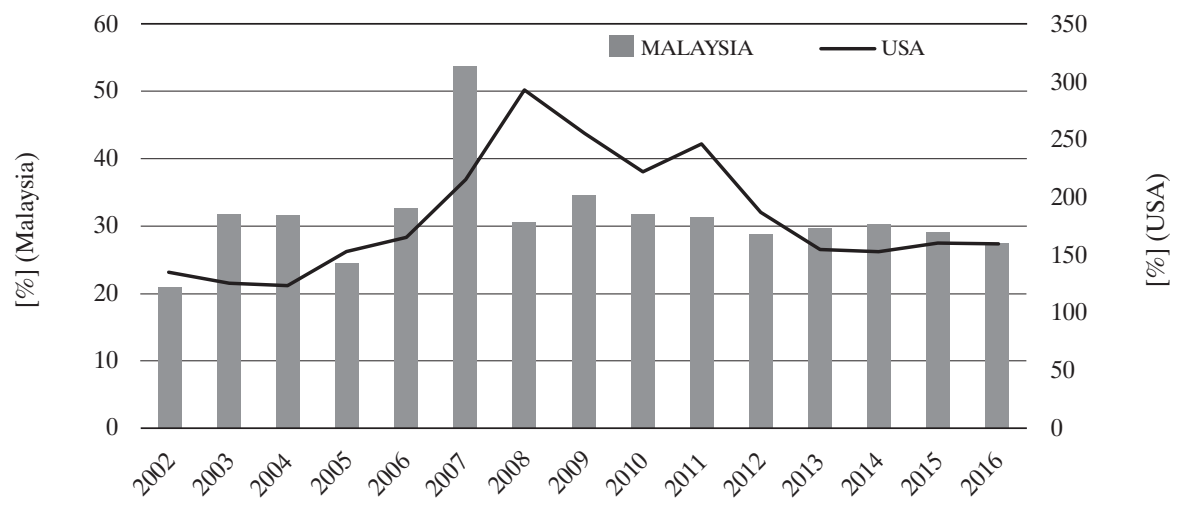

Source: Own study on the www.data.imf.org.

In the periods 2005-2007 and 2014-2016 the trends of both parameters are coincides. In the period 2008-2013 trends of both parameters are opposites. 
The correlation coefficient in the analyzed period is 0.34. Average of Stock Market Turnover Ratio to GDP of Malaysia is $31.29 \%$. Figure 25 presents the Kuala Lumpur Stock Exchange benchmark values within the analyzed period.

F ig u re 25. KLCI Index values, 2002-2017

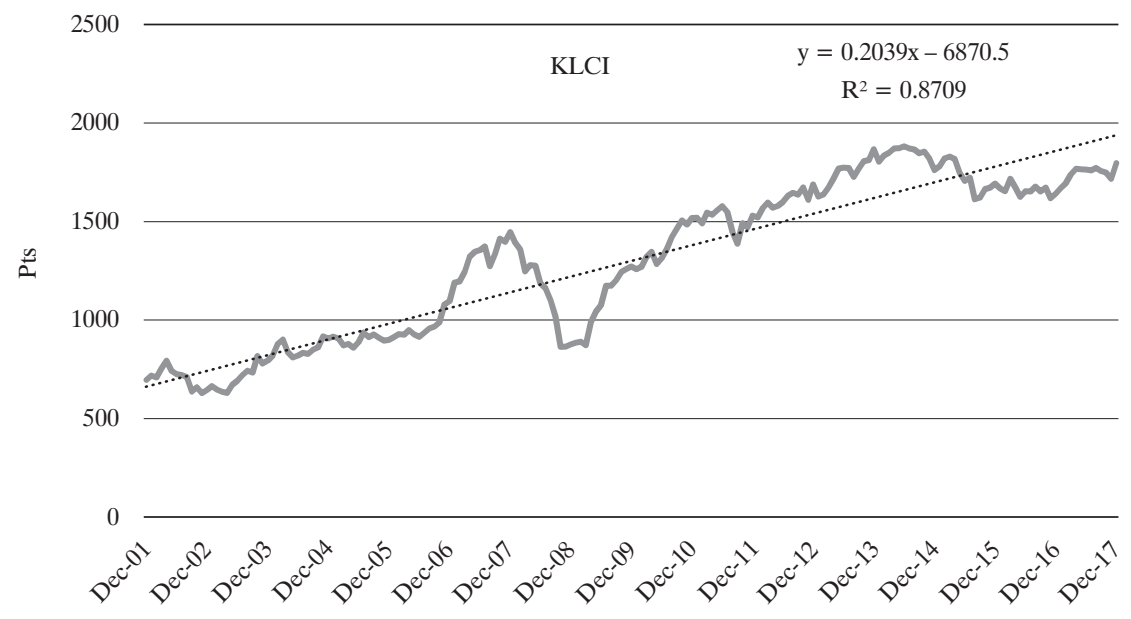

Source: Own study on the www.Stooq.pl.

The correlation coefficient value between KLCI Index and Malaysia Stock Market Capitalization to GDP is $92.27 \%$. The correlation coefficient value between KLCI Index and Malaysia Stock Market Total Value Traded to GDP is 83.37\%. The correlation coefficient value between KLCI Index and Malaysia Stock Market Turnover Ratio to GDP is $90.19 \%$.

\section{Mexico}

Mexico is the second biggest (the first one being Brazil) economy in Latin America. Seven out of ten inhabitants live in poverty or are at risk of living in poverty (according to the OECD). The annual inflation rate is a steady $5 \%$ (the central bank aims to reduce it to $3 \%$ ). Strong economic ties between Mexico and the US (export representing about 80\%) and the huge disproportion between the interest rates (7.75\% in Mexico vs. 2.25\% in the US) are not in favor of the Mexican peso. The GDP and the inflation rate evolution in the period 2002-2017 are presented in Figure 26. 
F ig u re 26. GDP and Mexico Inflation Rate, 2002-2017

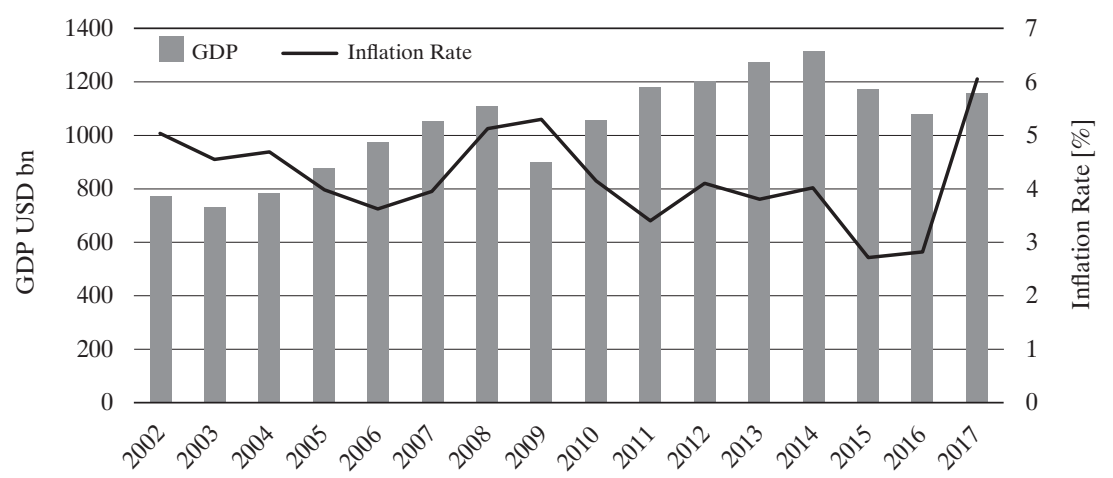

Source: Own study on the www.data.imf.org.

Mexico carries a high political risk for investors. In 2013, for the first time in 75 years, the former president Enrique Peña Nieto opened the Mexican oil and natural gas sector to domestic and foreign private capital. The current president, Andres Obrador, the first social-democrat in a very long time, wants the state to closely control the private sector, while analysts pinpoint that foreign investments are necessary. Figure 27 presents the Mexican's structure of the financial market in relation to GDP ratio within the analyzed period.

\section{F i g u r e 27. Mexican's structure financial market ratio to GDP, 2002-2016}

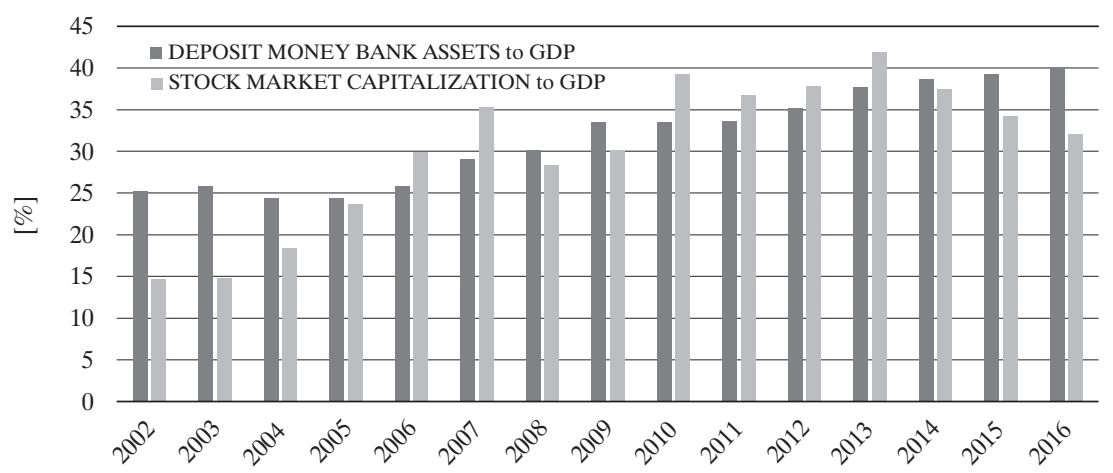

Source: Own study on the www.data.imf.org.

The Mexico Stock Exchange is less developed than the banking sector. In the periods 2002-2007 and 201-2016, the trends of both parameters are contradictory; in the period 2008-2013, trends of both parameters are concurrent. The 
correlation coefficient in the analyzed period is 0.76 . Average of Deposit Money Bank Assets to GDP of Mexico is $31.73 \%$; average of Stock Market Capitalization to GDP of Mexico is $30.28 \%$. Figure 28 presents the Stock Market Total Value Traded to GDP ratios for Mexico and the US within the analyzed period.

F i g u r e 28. Stock Market Total Value Traded to GDP ratio for Mexico and the US, 2002-2016

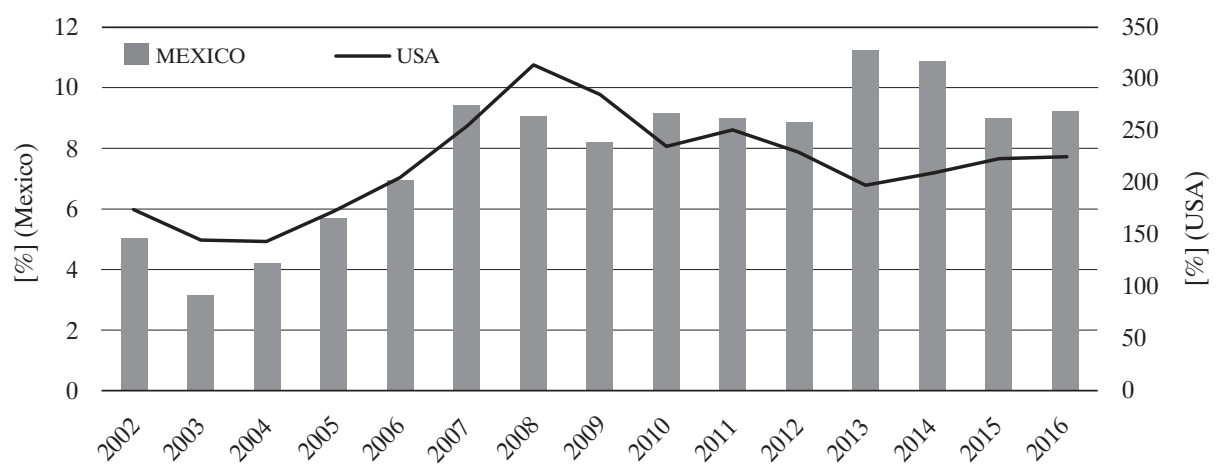

Source: Own study on the www.data.imf.org.

In the periods 2002-2012 and 2015-2016, the trends of both parameters are coincides. In the period 2013-2014 trends of both parameters are opposites. The correlation coefficient in the analyzed period is 0.65. Average of Stock Market Total Value Traded to GDP of Mexico is 7.93\%. Figure 29 presents the Stock Market Turnover Ratio to GDP for Mexico and the US within the analyzed period.

F i g u r e 29. Stock Market Turnover Ratio to GDP of Mexico and the US, 2002-2016

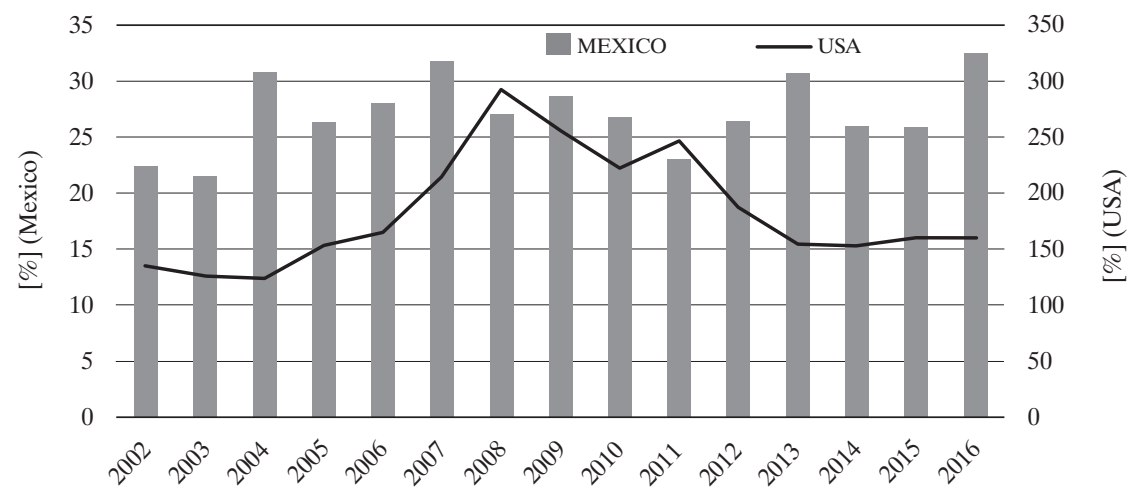

Source: Own study on the www.data.imf.org. 
In the period 2002-2010 the trends of both parameters are coincides. In the period 2011-2016 trends of both parameters are opposites. The correlation coefficient in the analyzed period is 0.06 . Average of Stock Market Turnover Ratio to GDP of Mexico is $27.18 \%$. Figure 30 presents the Mexican Stock Exchange benchmark values within the analyzed period.

F ig u re 30. IPC Index Values, 2002-2017

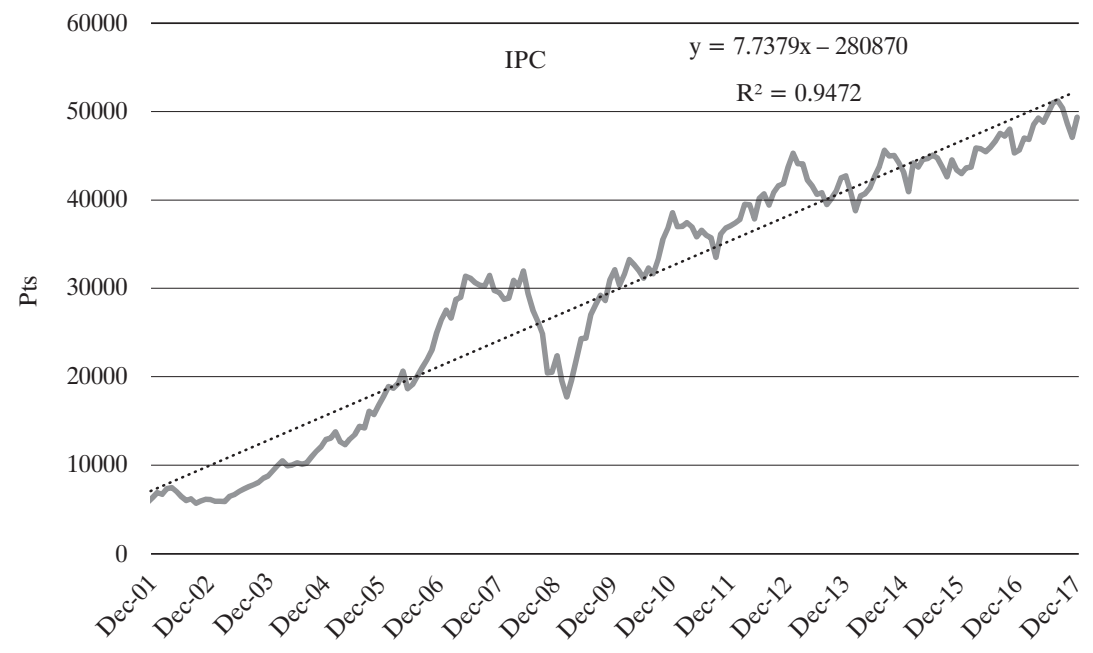

Source: Own study on the www.Stooq.pl.

The correlation coefficient value between IPC Index and Mexico Stock Market Capitalization to GDP is $91.46 \%$. The correlation coefficient value between IPC Index and Mexico Stock Market Total Value Traded to GDP is $87.63 \%$. The correlation coefficient value between IPC Index and Mexico Stock Market Turnover Ratio to GDP is $84.56 \%$.

\section{South Africa}

The Republic of South Africa (RSA) is one of the weakest emerging markets. The RSA's unemployment rate is very high (around 27\%), its inflation rate is relatively high (around 5\%), and the consequences of the 2011-2016 economic recession remain serious (Fig. 31). 


\section{F i g u re 31. GDP and South Africa Inflation Rate, 2002-2017}

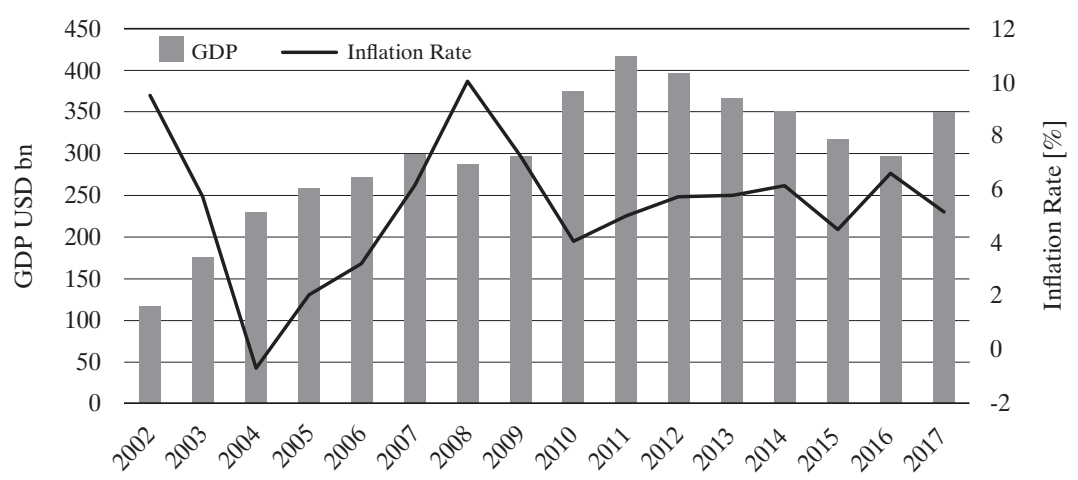

Source: Own study on the www.data.imf.org.

The RSA seems to be headed towards dangerous socialism; all major international analytical centers have been warning about that. In the summer of 2018 the RSA president Cyril Ramaphosa supported a bill allowing the seizure of farms from white farmers without giving them any compensations. The topdown 'agrarian reform' is meant to give land to black citizens, who were the poorest social group during the apartheid period. Figure 32 presents the South African's structure of the financial market in relation to GDP ratio within the analyzed period.

F i g u r e 32. South African structure financial market ratio to GDP, 2002-2016

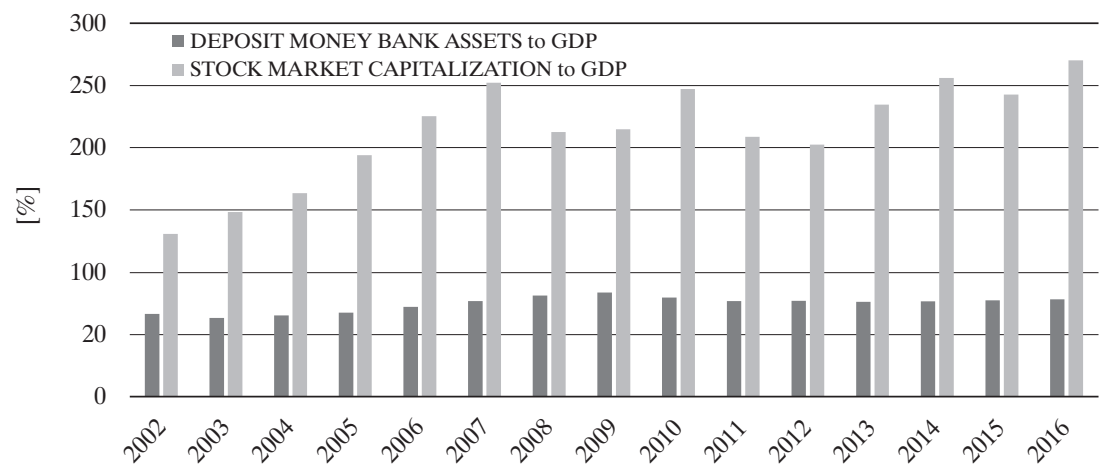

Source: Own study on the www.data.imf.org. 
The South African's stock exchange is definitely less developed than the banking sector. The amplitude of changes of Stock Market Capitalization to $G D P$ is much smaller than the amplitude of changes of Deposit Money Bank Assets to GDP. The correlation coefficient in the analyzed period is 0.74 . Average of Deposit Money Bank Assets to GDP of South Africa is $74.77 \%$; average of Stock Market Capitalization to GDP of South Africa is 213.67\%. Figure 33 presents the Stock Market Total Value Traded to GDP ratios for South Africa and the US within the analyzed period.

F i g u r e 33. Stock Market Total Value Traded to GDP ratio for South Africa and the US, 2002-2016

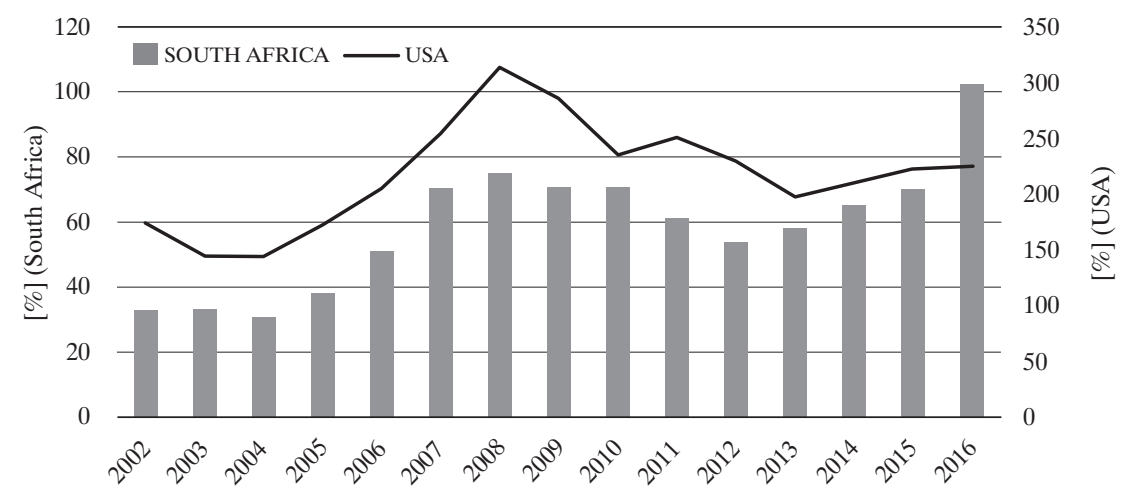

Source: Own study on the www.data.imf.org.

In the period 2002-2015 the trends of both parameters are coincides. The correlation coefficient in the analyzed period is 0.72 . Average of Stock Market Total Value Traded to GDP of South Africa is 53.38\%. Figure 34 presents the Stock Market Turnover Ratio to GDP for South Africa and the US within the analyzed period. 
F i g u r e 34. Stock Market Turnover Ratio to GDP of South Africa and the US, 2002-2016

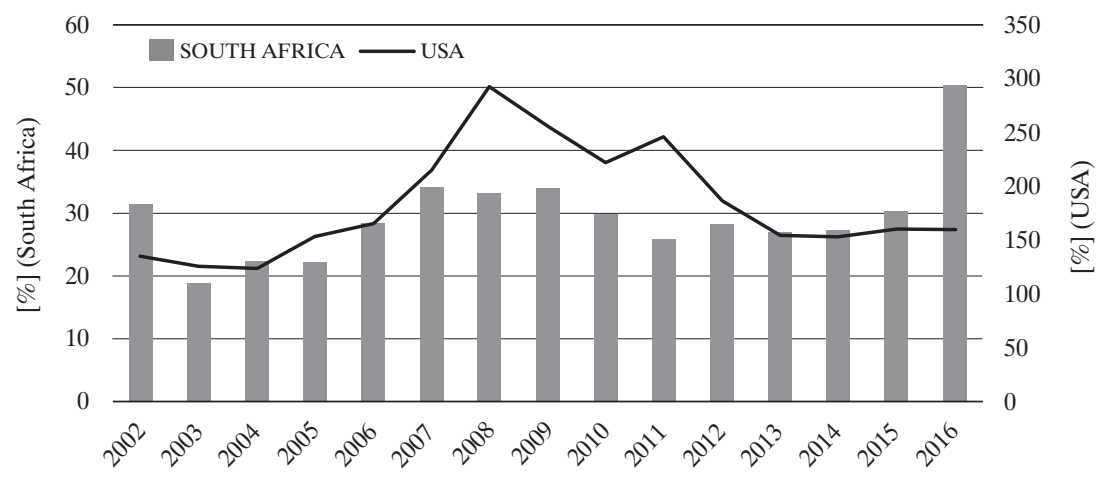

Source: Own study on the www.data.imf.org.

In the period 2002-2007 the trends of both parameters are coincides. In the period 2008-2016 trends of both parameters are opposites. The correlation coefficient in the analyzed period is 0.28. Average of Stock Market Turnover Ratio to GDP of South Africa is $29.58 \%$. Figure 35 presents the Johannesburg Stock Exchange benchmark values within the analyzed period.

F i g u r e 35. JELSH Index Values, 2002-2017

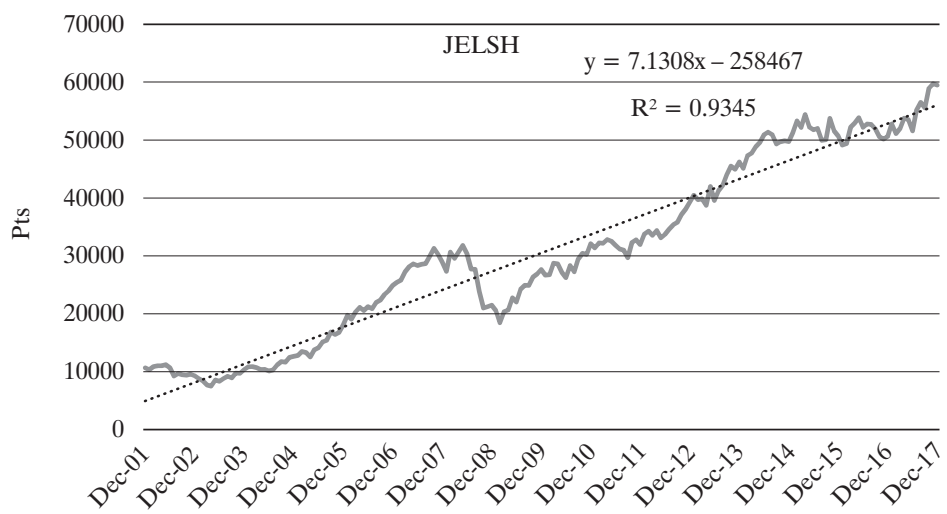

Source: Own study on the www.Stooq.pl.

The correlation coefficient value between JELSH Index and South Africa Stock Market Capitalization to GDP is $84.67 \%$. The correlation coefficient value between JELSH Index and South Africa Stock Market Total Value Traded 
to GDP is $81.80 \%$. The correlation coefficient value between JELSH Index and South Africa Stock Market Turnover Ratio to GDP is $80.18 \%$.

\section{Thailand}

Thailand is the second biggest economy (the first one being Indonesia) in South-East Asia. Between 2002 and 20018 its GDP increased considerably (Fig. 36).

F i g u re 36. GDP and Thailand Inflation Rate, 2002-2017

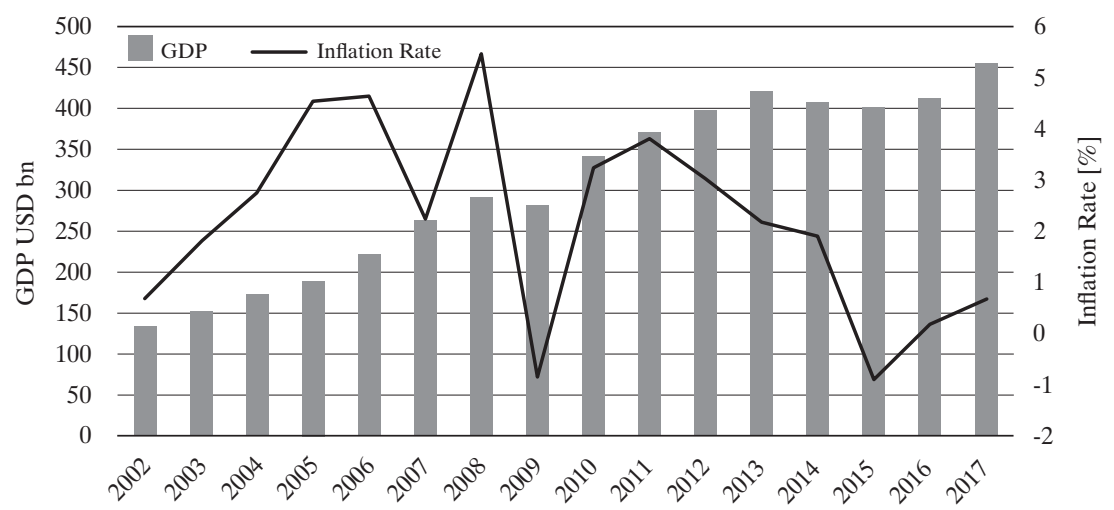

Source: Own study on the www.data.imf.org.

The average annual GDP growth rate was $8.37 \%$ during the period under assessment. The industry and the services are the two predominant sectors generating most GDP. The automotive industry is the one that generates the biggest part of it; Thailand is the number one car manufacturer in the SouthEast, and the ninth worldwide, although most are foreign models rather than genuine national products. Tourism represents about $7 \%$ of GDP; $16.5 \%$ if indirectly generated revenues are included. Bangkok, as the main gate to Thailand, is considered a tourism leader, generating a 30\% GDP increase. The unemployment rate is only $0.7 \%$, one of the lowest in the world. The inflation rate is $3 \%$ and the interest rate is $2.75 \%$. Figure 37 presents the Thailand's structure of the financial market in relation to GDP ratio within the analyzed period. 


\section{F i g u re 37. Thailand's structure financial market ratio to GDP, 2002-2016}

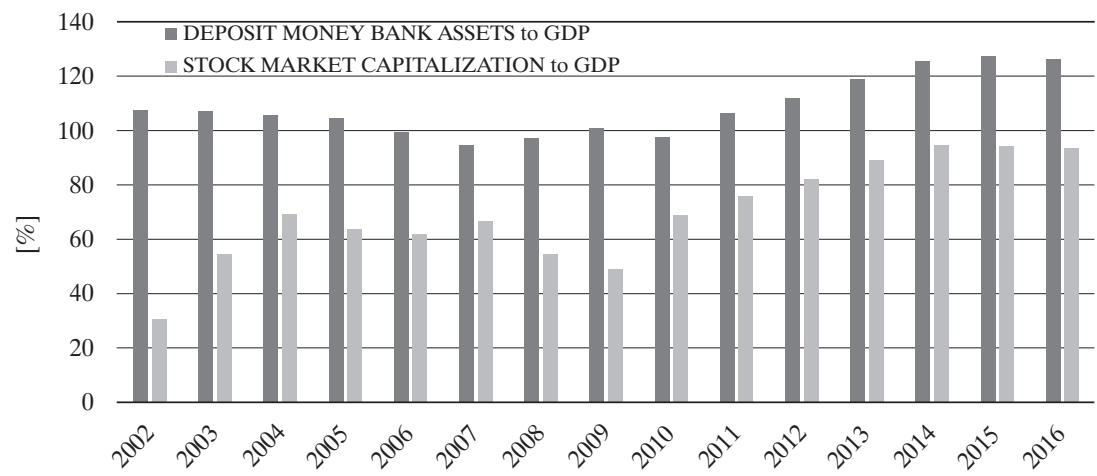

Source: Own study on the www.data.imf.org.

The Thailand's stock exchange is definitely less developed than the banking sector. In the period 2002-2010, trends of both parameters are contradictory. In the period 2011-2016, trends of the analyzed parameters are concurrent. The correlation coefficient in the analyzed period is 0.72. Average of Deposit Money Bank Assets to GDP of Thailand is $110.2 \%$; average of Stock Market Capitalization to GDP of Thailand is $70.02 \%$. Figure 38 presents the Stock Market Total Value Traded to GDP ratios for Thailand and the US within the analyzed period.

F i g u r e 38. Stock Market Total Value Traded to GDP ratio for Thailand the US, 2002-2016

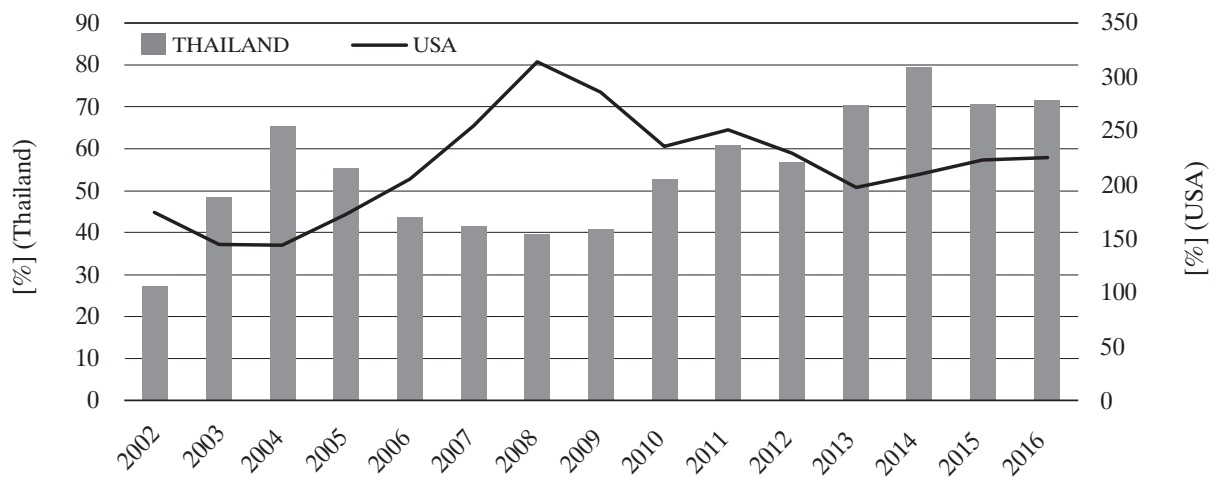

Source: Own study on the www.data.imf.org. 
In the period 2002-2016 trends of both parameters are opposites. The correlation coefficient in the analyzed period is -0.2. Average of Stock Market Total Value Traded to GDP of Thailand is 55.0\%. Figure 39 presents the Stock Market Turnover Ratio to GDP for Thailand and the US within the analyzed period.

F i g u r e 39. Stock Market Turnover Ratio to GDP of Thailand and the US, 2002-2016

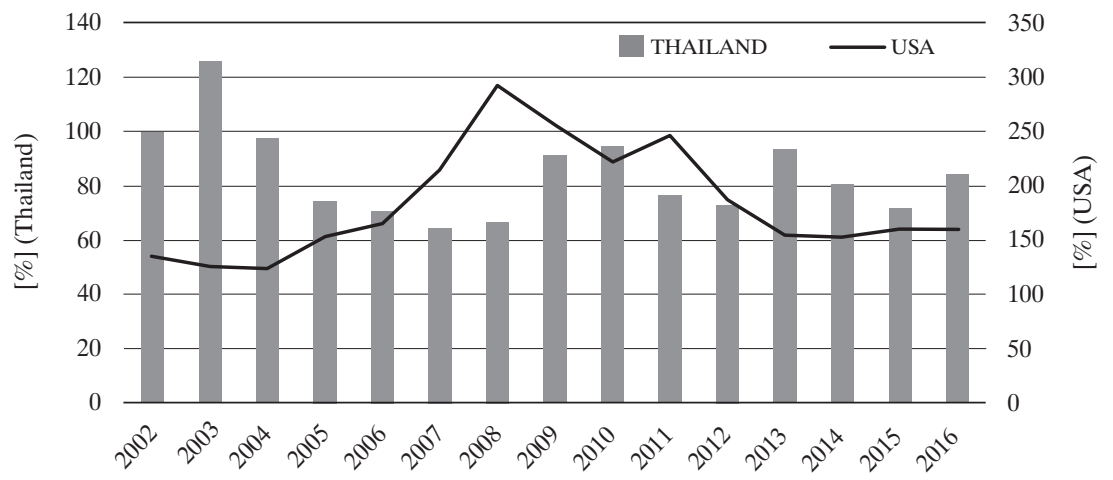

Source: Own study on the www.data.imf.org.

In the period 2002-2016 trends of both parameters are opposites. The correlation coefficient in the analyzed period is -0.46 . Average of Stock Market Turnover Ratio to GDP of Thailand is 84.25 . Figure 40 presents the Stock Exchange of Thailand benchmark values within the analyzed period.

F i g u r e 40. SET Index Values, 2002-2017

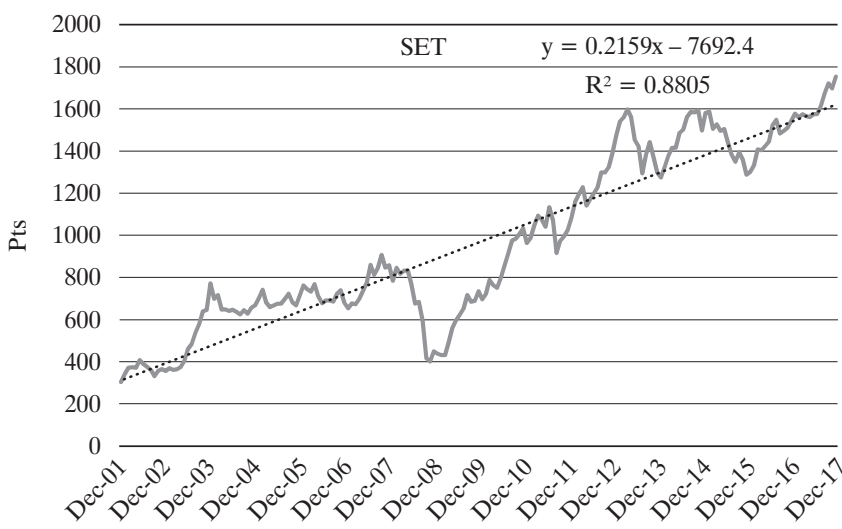

Source: Own study on the www.Stooq.pl. 
The correlation coefficient value between SET Index and Thailand Stock Market Capitalization to GDP is $93.93 \%$. The correlation coefficient value between SET Index and Thailand Stock Market Total Value Traded to GDP is 93.13\%. The correlation coefficient value between SET Index and Thailand Stock Market Turnover Ratio to GDP is $84.97 \%$.

\section{Turkey}

Until 2014 Turkey was one of the fastest developing economies (Fig. 41).

F ig u r e 41. GDP and Turkey Inflation Rate, 2002-2017

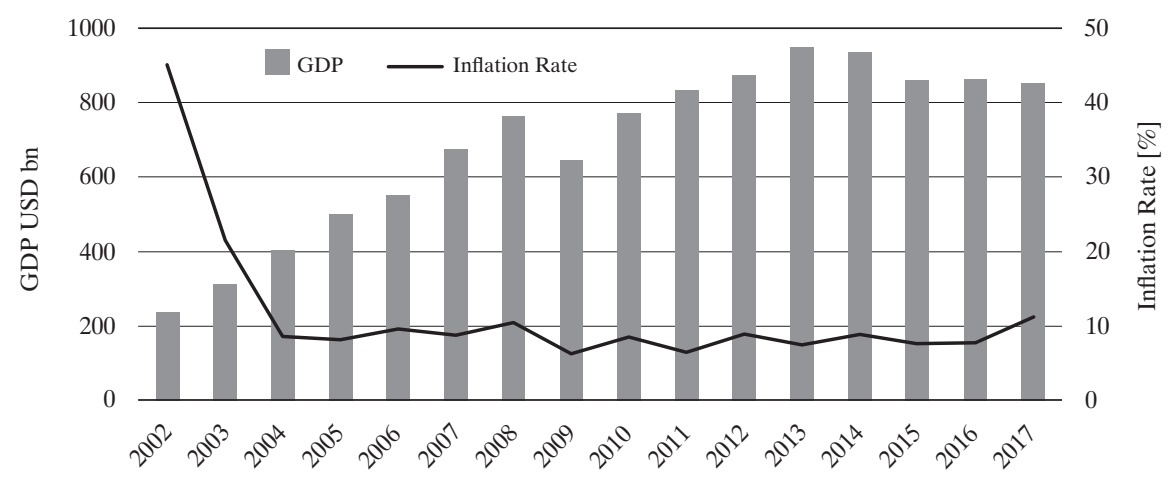

Source: Own study on the www.data.imf.org.

The construction sector accounted for 10\% of GDP. Apart from the investments in construction Turkey, supported by the 'cheaper' foreign loans, focused on developing government investments and on building new factories. Such a policy led to deficits, on both accounts the fiscal revenues and the checking ones, causing a debt accumulation of $\$ 460$ billion, i.e. over half of the Turkish GDP. The President Recep Erdogan wants to maintain strong economic growth at any cost and therefore interferes with the independence of the central bank. According to him, low interest rates are key to success. However, decision-makers at the central bank of the Republic of Turkey disagree and are prone to increase the main interest rates. The attacks on the Kurds and the conflict with Donald Trump's administration increased political and economic risk, which led to depreciation of the Turkish lira; since the end of 2017 it has been depreciated by almost $50 \%$, which raised concerns about a potential crisis on the Turkish market of foreign currency loans. There is also a serious threat in the financial sector. Turkish businesses have loans in foreign currencies in many 
foreign banks. According to the Bank of International Settlements (BIS), the amounts of those loans in foreign banks are: $\$ 83.3$ billion in Spain, $\$ 38.4$ billion in France, and $\$ 17$ billion in Italy. Figure 42 presents the Turkey's structure of the financial market in relation to GDP ratio within the analyzed period.

\section{F i g u r e 42. Turkey's structure financial market ratio to GDP, 2002-2016}

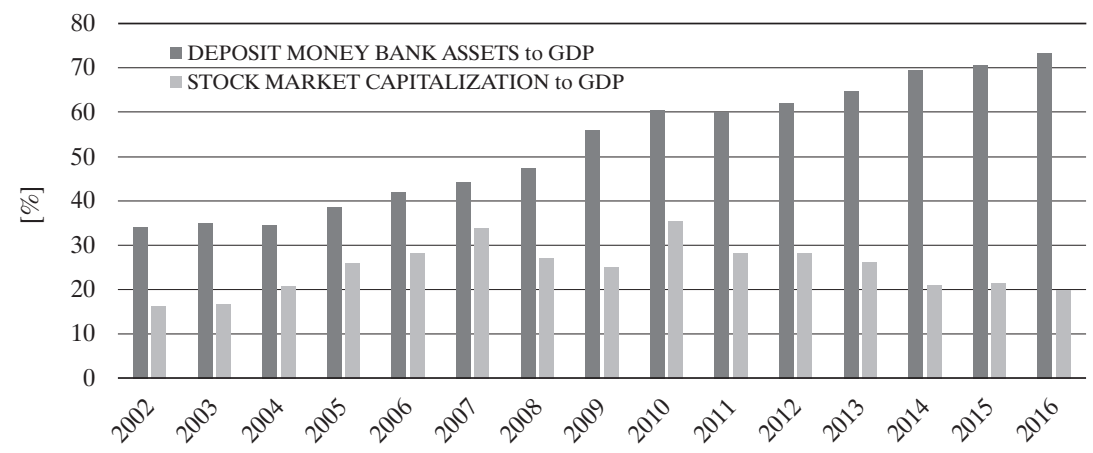

Source: Own study on the www.data.imf.org.

The Turkey's stock exchange is definitely less developed than the banking sector. In the period 2002-2007, trends of both parameters are contradictory. In the period 2008-2016, trends of the analyzed parameters are concurrent. The correlation coefficient in the analyzed period is 0.15 . Average of Deposit Money Bank Assets to GDP of Turkey is 52.86\%; average of Stock Market Capitalization to GDP of Brazil is $24.09 \%$. Figure 43. presents the Stock Market Total Value Traded to GDP ratios for Turkey and the US within the analyzed period.

F i g u r e 43. Stock Market Total Value Traded to GDP ratio for Turkey and the US, 2002-2016

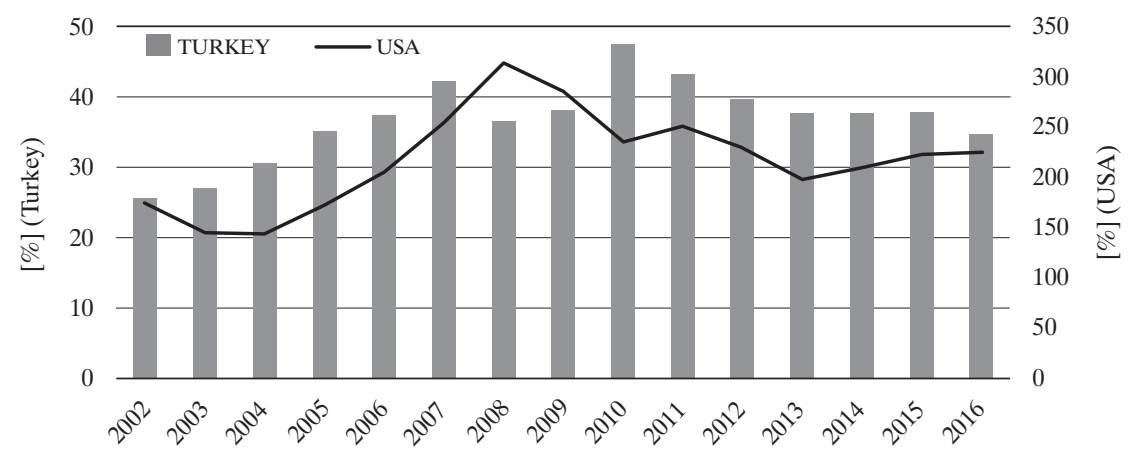

Source: Own study on the www.data.imf.org. 
In the periods 2002-2007 and 2011-2016, the trends of both parameters are coincides. In the period 2008-2010 trends of both parameters are opposites. The correlation coefficient in the analyzed period is 0.62. Average of Stock Market Total Value Traded to GDP of Turkey is $36.72 \%$. Figure 44 presents the Stock Market Turnover Ratio to GDP for Turkey and the US within the analyzed period.

\section{F i g u r e 44. Stock Market Turnover Ratio to GDP of Turkey and the US, 2002-2016}

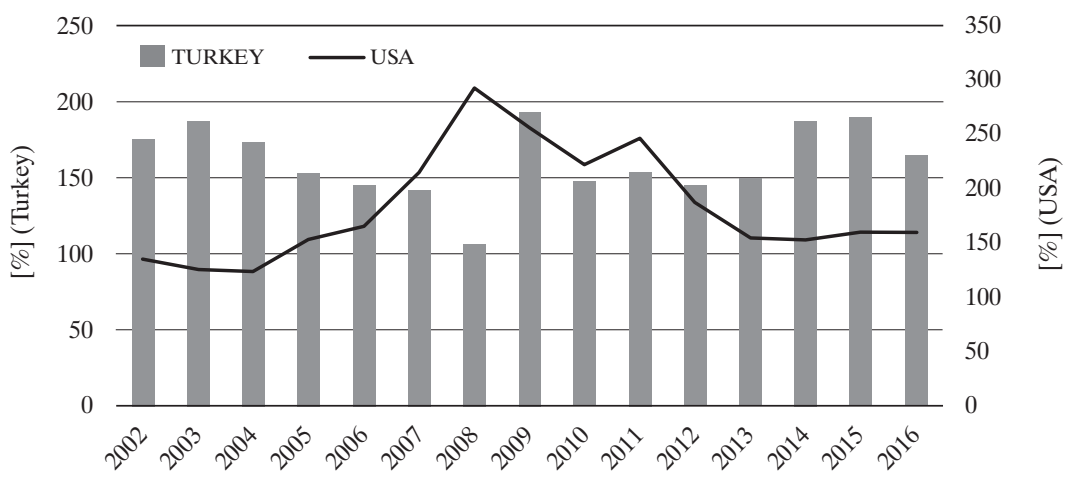

Source: Own study on the www.data.imf.org.

In the period 2010-2012, the trends of both parameters are coincides. In the periods 2002-2009 and 2013-2016 trends of both parameters are opposites. The correlation coefficient in the analyzed period is -0.52 Average of Stock Market Turnover Ratio to GDP of Turkey is $160.94 \%$. Figure 45 presents the Istanbul Stock Exchange benchmark values within the analyzed period.

F ig u r e 45. BIST 100 Index Values, 2002-2017

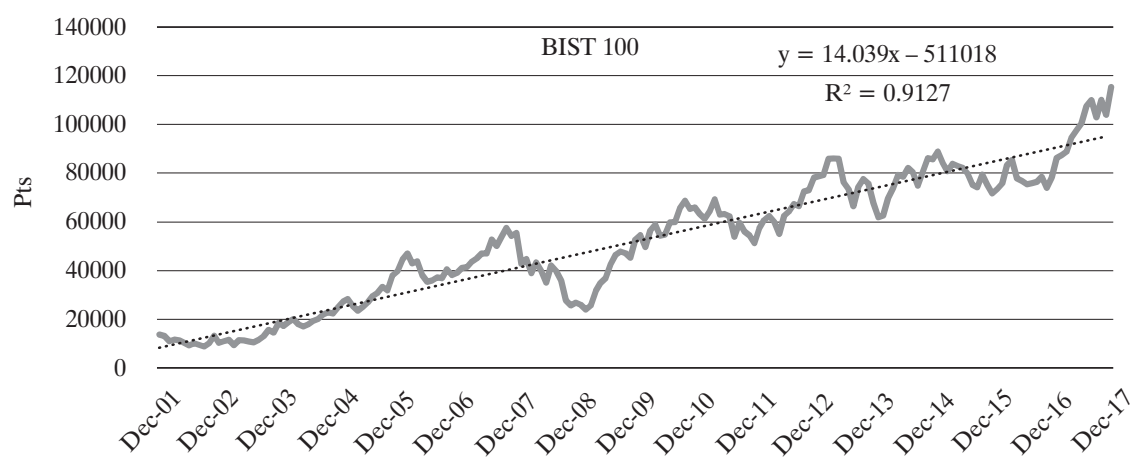

Source: Own study on the www.Stooq.pl. 
The correlation coefficient value between BIST100 Index and Turkey Stock Market Capitalization to GDP is $73.45 \%$. The correlation coefficient value between BIST100 Index and Turkey Stock Market Total Value Traded to GDP is $85.90 \%$. The correlation coefficient value between BIST100 Index and Turkey Stock Market Turnover Ratio to GDP is $92.80 \%$.

\section{Conclusion}

Brazil is the largest of the markets analyzed and Hungary is the smallest (Table 1).

Tab le 1. Emerging Markets Scale

\begin{tabular}{|l|c|c|c|c|c|}
\hline \multirow{2}{*}{ COUNTRY } & $\begin{array}{c}\text { FINANCIAL } \\
\text { MARKET }\end{array}$ & \multicolumn{2}{c|}{$\begin{array}{c}\text { DEPOSIT MONEY } \\
\text { BANK ASSETS }\end{array}$} & \multicolumn{2}{c|}{$\begin{array}{c}\text { STOCK MARKET } \\
\text { CAPITALIZATION }\end{array}$} \\
\cline { 2 - 6 } & USD bn & USD bn & \% GDP & USD bn & $\%$ GDP \\
\hline BRAZIL & 2073 & 1298 & 80 & 775 & 48 \\
\hline SOUTH AFRICA & 856 & 222 & 75 & 634 & 214 \\
\hline MEXICO & 640 & 327 & 32 & 313 & 30 \\
\hline MALAYSIA & 562 & 264 & 117 & 298 & 132 \\
\hline THAILAND & 536 & 328 & 110 & 208 & 70 \\
\hline TURKEY & 528 & 358 & 53 & 170 & 25 \\
\hline GREECE & 378 & 278 & 109 & 100 & 39 \\
\hline CZECH REPUBLIC & 138 & 102 & 57 & 36 & 20 \\
\hline HUNGARY & 102 & 77 & 63 & 25 & 20 \\
\hline
\end{tabular}

Source: Own study on the www.data.imf.org.

The analysis of the relationship of the Stock Market Capitalization to GDP and the Deposit Money Bank to GDP allows determining the classes of emerging markets (Table 2). 
Table 2. Emerging Market classes

\begin{tabular}{|l|l|l|l|l|}
\hline $\begin{array}{c}\text { Markets with strong } \\
\text { banking sector } \\
\text { domination(a) }\end{array}$ & $\begin{array}{c}\text { Markets with } \\
\text { banking sector } \\
\text { domination(b }\end{array}$ & $\begin{array}{c}\text { Markets with } \\
\text { a balanced } \\
\text { structure(c) }\end{array}$ & $\begin{array}{c}\text { Markets with } \\
\text { stock exchange } \\
\text { domination(d) }\end{array}$ & $\begin{array}{c}\text { Markets with strong } \\
\text { stock exchange } \\
\text { domination(e) }\end{array}$ \\
\hline $\begin{array}{l}\text { Greece } \\
\text { Thailand }\end{array}$ & $\begin{array}{l}\text { Brazil } \\
\text { Czech Republic } \\
\text { Hungary } \\
\text { Turkey }\end{array}$ & Mexico & Malaysia & South Africa \\
\hline
\end{tabular}

(a) "deposit money bank assets > GDP" and "stock market capitalization < GDP"

(b) "deposit money bank assets > stock market capitalization"

(c) "deposit money bank assets $\approx$ stock market capitalization"

(d) "stock market capitalization > deposit money bank assets"

(e) "stock market capitalization > GDP" and "deposit money bank assets < GDP"

Source: Own study on the www.data.imf.org.

The above relations are presented in the Figure 46.

\section{F i g u re 46. Emerging markets Structure}

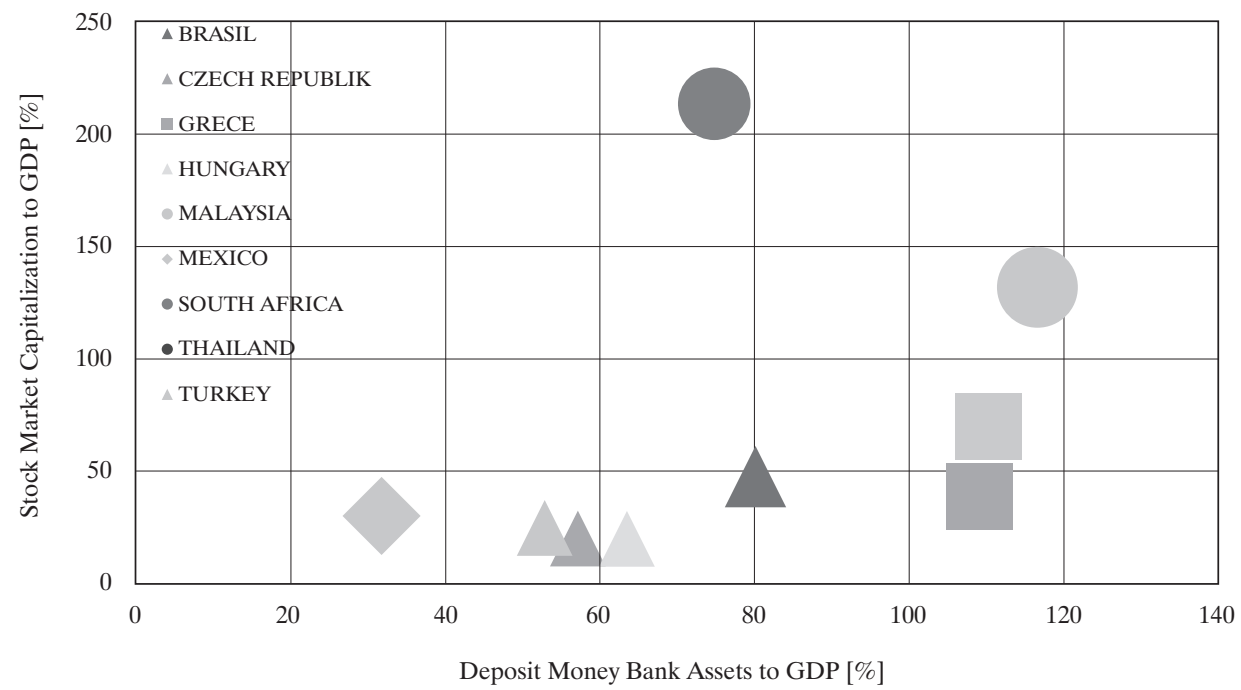

Source: Own study on the www.data.imf.org. 
The grouping of similar structures of markets is visible. Introducing parameters:

Relative Stock Market Total Value Traded $=\frac{\text { Country's Stock Market Total Value Traded ratio to GDP }}{\text { US' Stock Market Total Value Traded to GDP }}$

Country's Stock Market Tournover Ratio to GDP

Relative Stock Market Turnover Ratio =

US' Stock Market Tournover Ratio to GDP

allowed to determine the relationship between the analyzed markets (Fig. 47).

\section{F i g u r e 47. Emerging Market Relations}

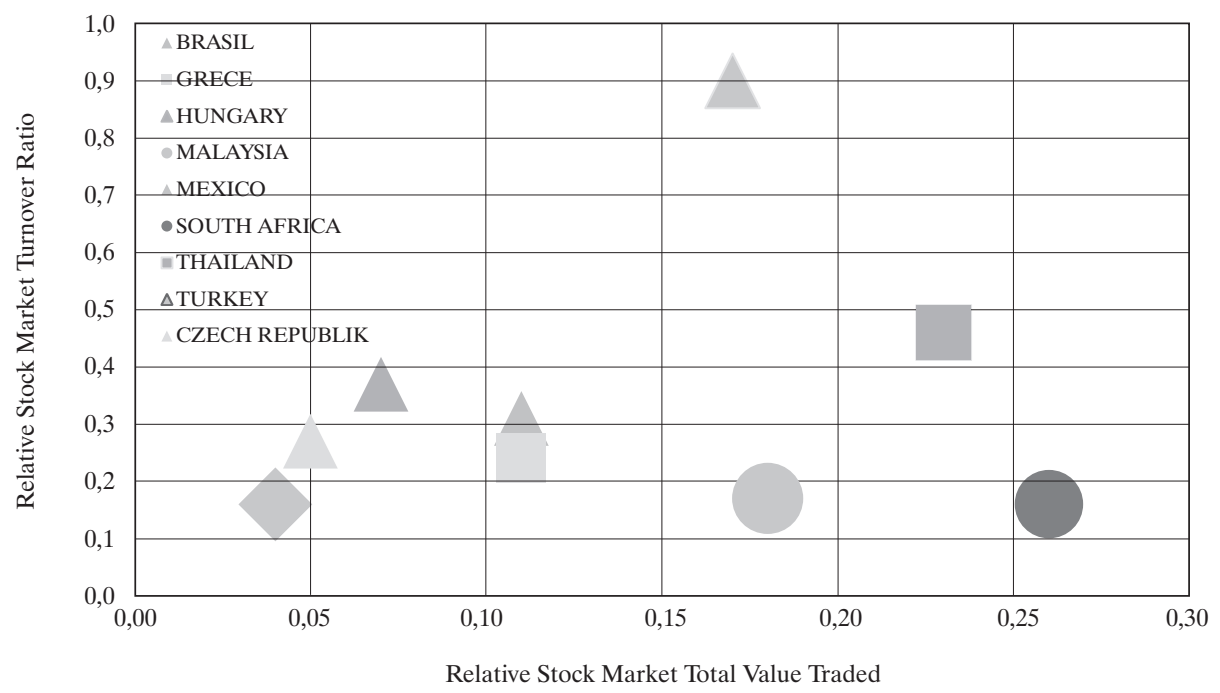

Source: Own study on the www.data.imf.org.

The Turkish stock market is the most dynamic, despite the fact that the Turkish market belongs to markets with a dominance class of the banking sector. The least dynamic, although it belongs to the class of markets with strong stock market dominance. The benchmark characteristics of the analyzed exchanges are presented in Table 3 . 
Table 3. Benchmark characteristics

\begin{tabular}{|c|c|c|c|c|c|}
\hline \multirow{2}{*}{ STOCK EXCHANGE } & \multirow{2}{*}{ INDEX } & \multicolumn{2}{|c|}{ Value [Pts] } & \multirow{2}{*}{$\begin{array}{c}\text { Annualized } \\
\text { Rate of } \\
\text { Return [\%] }\end{array}$} & \multirow{2}{*}{ Trend } \\
\hline & & 31.12.2001 & 31.12.2017 & & \\
\hline $\begin{array}{l}\text { Brazil } \\
\text { Stock Exchange }\end{array}$ & BOVESPA & 13577.57 & 76402.08 & 11.40 & $y=8.5964 x-299162$ \\
\hline $\begin{array}{l}\text { Prague } \\
\text { Stock Exchange }\end{array}$ & PX & 394.60 & 1078.16 & 6.48 & $y=0.0184 x+306.86$ \\
\hline $\begin{array}{l}\text { Athens } \\
\text { Stock Exchange }\end{array}$ & ATHEX & 2591.56 & 802.37 & -7.07 & $y=-0.4907 x+21685$ \\
\hline $\begin{array}{l}\text { Budapest } \\
\text { Stock Exchange }\end{array}$ & BUX & 7131.13 & 39377.31 & 11.27 & $y=3.4138 x-117150$ \\
\hline $\begin{array}{l}\text { Kuala Lumpur } \\
\text { Stock Exchange }\end{array}$ & KLCI & 696.09 & 1796.81 & 6.11 & $\mathrm{y}=0.2039 x-6870.5$ \\
\hline $\begin{array}{l}\text { Mexican } \\
\text { Stock Exchange }\end{array}$ & IPC & 6372.28 & 49354.42 & 13.65 & $y=7.7379 x-280870$ \\
\hline $\begin{array}{l}\text { Johannesburg } \\
\text { Stock Exchange }\end{array}$ & JELSH & 10668.59 & 59504.67 & 11.34 & $y=7.1308 x-258467$ \\
\hline $\begin{array}{l}\text { Stock Exchange } \\
\text { of Thailand }\end{array}$ & SET & 303.85 & 1753.71 & 11.58 & $\mathrm{y}=0.2159 \mathrm{x}-7692.4$ \\
\hline $\begin{array}{l}\text { Istanbul } \\
\text { Stock Exchange }\end{array}$ & BIST 100 & 13782.76 & 115333.01 & 14.20 & $\mathrm{y}=14.039 \mathrm{x}-511018$ \\
\hline
\end{tabular}

Source: Own study on the www.Stooq.pl.

The highest rate of return was achieved by the Istanbul Stock Exchange benchmark and the lowest (negative) benchmark by Athens Stock Exchange. Benchmarks of the stock exchanges: Brazil Stock Exchange, Budapest Stock Exchange, Johannesburg Stock Exchange and Stock Exchange of Thailand achieved comparable rates of return in the analyzed period. Benchmarks of the Prague Stock Exchange and Kuala Lumpur Stock Exchange achieved comparable rates of return (around 50\% of the benchmark rates of the previous group). The highest level of market risk was on the Istanbul Stock Exchange, and the lowest level of market risk was on the Prague Stock Exchange. The Brazil Stock Exchange, Mexican Stock Exchange, Johannesburg Stock Exchange exchanges were characterized by a comparable level of market risk (approx. 50\% of the market risk of Istanbul Stock Exchange). The level of market risk at Budapest Stock Exchange was about four times lower than at the Istanbul Stock Exchange. Kuala Lumpur Stock Exchange and Stock Exchange of Thailand was charac- 
terized by a low level of market risk, especially considering the rates of return achieved. The values of the correlation coefficient between benchmarks of the analyzed exchanges are presented in Figure 48.

\section{F ig u r e 48. Benchmark's Correlations Coefficient}

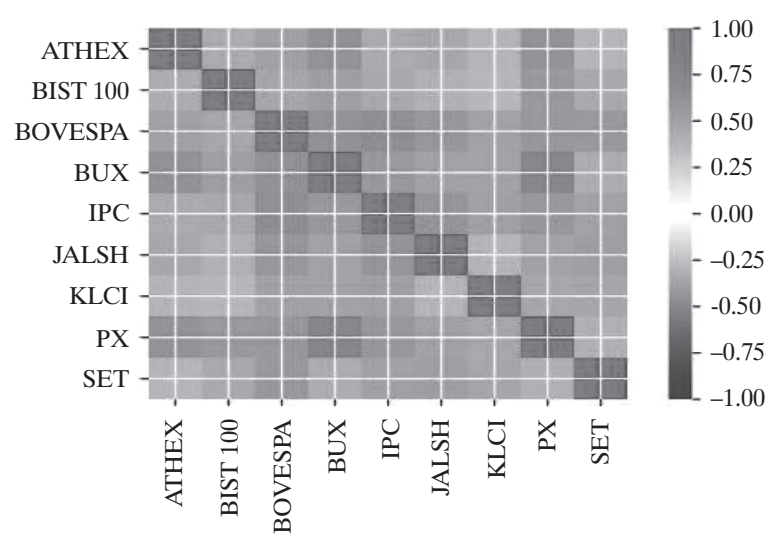

Source: Own study on the www.Stooq.pl.

The correlation coefficients of the rate of return of the analyzed indices are positive and are in the range $<0.37 ; 0.75>$. The Stock Exchange of Thailand SET benchmark with the Athens Stock Exchange ATHEX benchmark are the least correlated (0.37), while Prague Stock Exchange PX benchmark correlates most strongly with the Budapest Stock Exchange BUX benchmark (0.75).

\section{References}

Alhassan, A., \& Naka, A. (2020, January). Corporate future investments and stock liquidity: Evidence from emerging markets. International Review of Economics \& Finance, 65, 69-83.

Anastasopoulos, A. (2018, October). Testing for financial contagion: New evidence from the Greek crisis and yuan devaluation. Research in International Business and Finance, 45, 499-511.

Ballas, A.A., Chalevas, C., \& Tzovas, C. (2012). Market reaction to valuation adjustments for financial instruments: Evidence from Greece. Journal of International Accounting, Auditing and Taxation, 21(1), 52-61.

Birău, R., \& Antonescu, M. (2016, March). Investigating Long-term Dynamic Causal Linkages between Hungarian and Romanian Stock Markets. Procedia Economics and Finance, 16, 669-679.

Boako, G., \& Alagidede, P. (2018, December). African stock markets in the midst of the global financial crisis: Recoupling or decoupling? Research in International Business and Finance, 46, 166-180. 
Bortoluzzo, A.B., Accioly Fonseca Minardi, A.M., \& Passos, B.C.F. (2014, April-June). Analysis of multi-scale systemic risk in Brazil's financial market. Revista de Administração, 49(2), 240-250.

Coşkun, Y., Seven, U., Ertuğrul, H.M., \& Ulussever T. (2017, March). Capital market and economic growth nexus: Evidence from Turkey. Central Bank Review, 17(1), 19-29.

Delgado, B.E., \& Saucedo, E. (2018, July). The relationship between oil prices, the stock market and the exchange rate: Evidence from Mexico. The North American Journal of Economics and Finance, 45, 266-275.

Floros, Ch., Kizys, R., \& Pierdzioch, Ch. (2013, June). Financial crises, the decouplingrecoupling hypothesis, and the risk premium on the Greek stock index futures market. International Review off Financial Analysis, 28, 166-173.

Gonçalves B.A., Carpi L., Rosso, O.A., Ravetti, M.G., Atman A.P.F. (2019, July). Quantifying instabilities in Financial Markets. Physica A: Statistical Mechanics and its Applications, 525, 606-615.

Gregori, W.D., \& Sacchi, A. (2019, July). Has the Grexit news affected euro area financial market? The North American Journal of Economics and Finance, 49, 71-84.

Günay, S. (2016, March). Is political risk still an issue for Turkish stock market? Borsa Istanbul Review, 16(1), 21-31.

Habib, A.H., \& Elsayed, A.H. (2018). Are Islamic and conventional capital markets decoupled? Evidence from stock and bonds/sukuk markets in Malaysia. The Quarterly Review of Economics and Finance, In press, corrected proof, available online 18 April.

Kanjamapornkul, K., Pinčák, R., \& Bartoš, E. (2016, November). The study of Thai stock market across the 2008 financial crisis. Physica A: Statistical Mechanics and its Applications, 462, 117-133.

Kazanas, T., \& Tzavalis, E. (2014, March). Comment on "Fundamentally Wrong: Market Pricing of Sovereigns and the Greek Financial Crisis". Journal of Macroeconomics, 39(B), 420-423.

Kuper, G.H., \& Lestano, I. (2007, August). Dynamic conditional correlation analysis of financial market interdependence: An application to Thailand Indonesia. Journal of Asian Economics, 18(4), 670-684.

Kuzubaş, T.U., Ömercikoğlu, I., \& Saltoğlu, B. (2014, July). Network centrality measures and systemic risk: An application to the Turkish financial crisis. Physica A: Statistical Mechanics and its Applications, 405, 203-215.

Lai, Y.W., \& Windawati, A. (2017, December). Risk, return, and liquidity during Ramadan: Evidence from Indonesian and Malaysian stock markets. Research in International Business and Finance, 42, 233-241.

Li, F., \& Zhu H. (2014, September). Testing for financial contagion based on a nonparametric measure of the cross- marketcorrelation. Review of Financial Economics, 23(3), 141-147.

Lim, P.X., \& Goh K.L. (2018, July). Foreign equity flows: Boon or bane to the liquidity of Malaysian stock market? The North American Journal of Economics and Finance, 45, 161-181.

Majapa, M., \& Gossel, S.J. (2016, March). Topology of the South Africa stock market network across the 2008 financial crisis. Physica A: Statistical Mechanics and its Applications, 445, 35-47.

Mansilla, R., Terrero-Escalante, C.A., \& Alfonso, L. (2012, 15 May). On the scaling of the distribution of daily price fluctuations in the Mexican financial market index. Physica A: Statistical Mechanics and its Applications, 391(10), 2990-2996. 
Niţoi, M., \& Pochea, M. (2016, June). Testing financial markets convergence in Central and Eastern Europe: A non-linear single factor model. Economic Systems, 40(2), 323-334.

Oanea, D.C. (2015, November). Financial market integration: A vector error-correction approach. The Journal of Economic Asymmetries, 12(2), 153-161.

Omay, T., \& Iren, P. (2019, February). Behavior of foreign investors in the Malaysian stock market in times of crisis: A nonlinear approach. Journal of Asian Economics, 60, 85-100.

Shackleton, M.B., \& Voukelatos, N. (2013, April). Hedging efficiency in the Greek options market before and after the financial crisis of 2008. Journal of Multinational Financial Management, 23(1-2), 1-18.

Stringham, E., Boettke, P., \& Clark, J.R. (2008, August). Are regulations the answer for emerging stock markets? Evidence from the Czech Republic and Poland. The Quarterly Review of Economics and Finance, 48(3), 541-566.

Tang, X., \&Yao, X. (2018, March). Do financial structures affect exchange rate and stock price interaction? Evidence from emerging markets. Emerging Markets Review, 34, 64-76.

Vithessonthi, Ch. (2012, October). Financial market development and bank risk: Experience from Thailand during 1990-2012. Journal of Multinational Financial Management, 27, 67-88.

www.data.imf.org

www.Stooq.pl

Zhou, W.X., \& Sornette, D. (2009, 15 March). A case study of speculative financial bubbles in the South African stock market, 2003-2006. Physica A: Statistical Mechanics and its Applications, 388(6), 869-880. 


\title{
Rozdział 2
}

\author{
JOWITA GRZELAK
}

\section{Wskaźniki CAMEL \\ jako czynniki determinujące emisję obligacji typu contingent convertibles}

Ostatni kryzys finansowy wymusił na wielu państwach konieczność pomocy publicznej. Dominujące przekonanie, że niektóre instytucje finansowe są too big to fail, wymogło bezpośrednie dokapitalizowanie upadających banków przez państwo. Taka forma pomocy rządowej wykorzystywała pieniądze podatników, co określone zostało jako bail-out. Proces ten spotkał się z krytyką ze względu na kosztochłonność oraz rozszerzenie moral hazard wśród istotnych systemowo banków. Remedium dla upadających instytucji ma okazać się BRRD, czyli dyrektywa dotycząca restrukturyzacji i uporządkowanej likwidacji banków, tzw. Resolution, która zakłada m.in. koncepcję bail-in, czyli przeniesienia skutków upadłości na akcjonariuszy i wierzycieli. W ramach tego zjawiska dyrektywa wyodrębniła proces konwersji długu na kapitał akcyjny, który odbywać się może za pomocą obligacji warunkowo zamiennych, tzw. CoCo bonds. Celem niniejszego artykułu jest potwierdzenie hipotezy, iż wskaźniki CAMEL, reprezentujące adekwatność kapitałową, jakość aktywów, jakość zarządzania, efektywność i płynność banków, wpływają istotnie statystycznie na emisję obligacji CoCo. Weryfikacja hipotezy odbędzie się za pomocą regresji danych panelowych dla 65 banków notowanych na europejskich giełdach papierów wartościowych w okresie 2000-2018. Zebrane do badania dane pochodzą z bazy danych Thomson Reuters.

Słowa kluczowe: ryzyko upadłości, CoCo bonds, bank, Resolution, BRRD, bail-in.

\section{CAMEL Indices as Determinants of Issuing Contingent Convertibles Type of Bonds}

The recent financial crisis has forced public aid in many countries. The dominant belief that some financial institutions are too big to fail required direct recapitalization of the failing banks by the state. This form of government assistance used taxpayers' money, which was defined as

mgr Jowita Grzelak - doktorantka, Szkoła Doktorska Nauk Społecznych, Uniwersytet Warszawski, ul. Krakowskie Przedmieście 1, 00-047 Warszawa, Polska; https://orcid.org/0000-00026772-1019. 
a bail-out. This process was criticized due to the cost-intensive nature and the expansion of moral hazard among systemically important banks. The BRRD will be a remedy for failing institutions. It is Resolution Directive which, among other things, assumes the concept of bail-in, i.e. transferring the effects of bankruptcy on shareholders and creditors. As part of this phenomenon, the directive has distinguished the process of converting debt into share capital, which may be carried out with conditional changeable bonds, so-called CoCo bonds. The aim of this article is to confirm the hypothesis that CAMEL indices, representing capital adequacy, asset quality, management quality, effectiveness and liquidity of banks, significantly influence the issue of CoCo bonds. The verification of the hypothesis will be done through the regression of panel data for 65 banks listed on the European stock exchanges in the period from 2000 to 2018 year. The data collected for testing comes from the Thomson Reuters database.

Keywords: bankruptcy risk, CoCo bonds, bank, Resolution, BRRD, bail-in.

JEL: G21, G23, G33

\section{Wprowadzenie}

Szacuje się, że koszt bezpośredniego dokapitalizowania przez rządy państw Unii Europejskiej upadających na skutek kryzysu finansowego banków wyniósł ponad 400 miliardów euro (European Comisssion, 2012). Pieniądze wydawane w ramach pomocy publicznej pochodziły z kieszeni podatników, którzy to bezpośrednio odczuli skutki światowego kryzysu. Zjawisko to, zwane bail-out, stało się tematem wielu dyskusji ze względu na swoją kontrowersyjność (IwaniczDrozdowska, 2015). Z jednej strony bezpośrednia interwencja rządów państw miała zapobiec efektowi zarażania między bankami, który mógł rozprzestrzenić się poprzez system płatniczy, rynek lokat międzybankowych lub społeczny spadek zaufania do instytucji bankowych (Corrigan, 2006). Z drugiej strony, koszty tej pomocy odczuwali przede wszystkim podatnicy. Co więcej, przekonanie władz banków o obecnej pomocy od państwa wzmacniało zjawisko moral hazard, które sprawiło, że władze banków podejmowały bardziej ryzykowne decyzje, ograniczały zachowania prewencyjne i starały się osiągać jak największe zyski, nawet kosztem bezpieczeństwa. Odpowiedzią na te problemy ma być dyrektywa BRRD (Resolution), której głównym celem jest stworzenie jednolitego europejskiego mechanizmu restrukturyzacji i uporządkowanej likwidacji banków. Resolution zakłada przeciwny do dawnego bail-out proces bail-in, który ma na celu wyeliminowanie pomocy publicznej w obliczu upadłości banków i obarczenie jej skutkami akcjonariuszy i wierzycieli (Iwanicz-Drozdowska, 2015). W tym celu dyrektywa BRRD reguluje zestaw narzędzi, które jak najlepiej mają odpowiadać założeniem bail-in. Są to: możliwość sprzedaży banku, wydzielenie grupy aktywów banku, utworzenie banku pomostowego oraz umo- 
rzenie lub konwersja długu. $\mathrm{Z}$ punktu widzenia niniejszego artykułu na uwagę zasługuje ostatnie narzędzie oraz zawarte w Resolution zagadnienia dotyczące możliwości umorzenia instrumentów kapitałowych i ich zamiany na instrumenty właścicielskie w przypadku zagrożenia utartą wypłacalności (BRRD, 2014). Zjawisko to dotyczy właśnie obligacji contingent convertibles. CoCo wydaje się być idealnym instrumentem, którego głównym zadaniem jest absorpcja strat banku poprzez odciążenie go od konieczności spłaty długu i zamiana na kapitał przypominający akcyjny w sytuacjach niestabilności finansowych, przy jednoczesnym zachowaniu cech „typowego długu” przy stabilnej sytuacji (Liberadzki i Liberadzki, 2016). Taki mechanizm jest mniej kosztowny dla podmiotów finansowych niż utrzymywanie kosztownych kapitałów własnych, których koszt wyrażony jako stopa zwrotu dla właścicieli, często przewyższa koszt zaciągniętego długu (Admati i Hellwig, 2013). Co więcej, „przemiana” CoCos wpływa na wzrost kapitału podstawowego Tier1 poprzez zamianę na określoną wartość lub ilość akcji (Liberadzki i Liberadzki, 2016). W efekcie taki zabieg wpływa na wzrost współczynnika wypłacalności banku (poprzez zwiększenie kapitału regulacyjnego), a przy tym na ograniczenie ryzyka jego bankructwa. W świetle badania ryzyka upadłości banków oraz analizy skuteczności regulacji zawartych w dyrektywie BRRD, niniejszy artykuł skupia się na badaniu czynników, które wpływają na emisje CoCos przez banki. W tym celu postawiono hipotezę badawczą: wskaźniki CAMEL, reprezentujące adekwatność kapitałową, jakość aktywów, jakość zarządzania, efektywność i płynność banków, wpływają istotnie statystycznie na emisję obligacji $\mathrm{CoCo}$.

\section{Istota instrumentu CoCo bonds}

Emisja obligacji warunkowo zamiennych (CoCo bonds) spełnia warunki założonego przez Resolution procesu bail-in, który następuje w przypadku upadku banku. Istotą tego procesu jest odejście od pomocy rządowej dla upadającej instytucji finansowej, która jest bardzo kosztowna dla podatników danego państwa oraz przerzucenie skutków i strat na akcjonariuszy oraz nieubezpieczonych wierzycieli. W wyniku emisji obligacji typu CoCo przy zajściu określonego warunku tzw. triggera (najczęściej zaistnienia problemu związanego z utratą wypłacalności) dług banku automatycznie zostaje zamieniony w kapitał akcyjny (Calomiris, 2012). Zdarzenie inicjujące konwersję CoCo może mieć charakter księgowy (inicjacja procesu zamiany wywoływana jest na skutek zmian określonych wskaźników księgowych), rynkowy lub regulacyjny (Liberadzki i Liberadzki, 2016). Kapitał uzyskany w wyniku konwersji instrumentu, który zalicza się do kapitału AT 1 (Additional Tier1) na gruncie 
rozporządzenia CRR może zostać zakwalifikowany do kapitału regulacyjnego Tier1. Takie rozwiązanie ma wiele zalet. Po pierwsze zabieg ten jest znacznie tańszy dla banków niż utrzymywanie kapitałów właścicielskich, których koszt określany często jako stopa zwrotu dla właścicieli (ROE), przeważnie przewyższa koszt zaciągniętego długu (Admati i Hellwig, 2013). Konwersja CoCos, wpływając na wzrost kapitału regulacyjnego Tier1 poprzez zamianę na określoną wartość lub ilość akcji (Liberadzki i Liberadzki, 2016), powoduje wzrost współczynnika wypłacalności banku, co może być sygnałem ograniczenia ryzyka bankructwa i w konsekwencji upadłości banku. Emisja CoCos pozwala bankom na ograniczenie w bilansie nieefektywnych podatkowo kapitałów własnych (Liberadzki i Liberadzki, 2016). Utworzony w wyniku zamiany kapitał warunkowy minimalizuje ryzyko systematyczne instytucji i wspomaga proces zarówno wewnętrznego, jak i zewnętrznego zarządzania ryzykiem w stosunku do regulatora (Penacchi i in., 2013).

Co więcej, instrumenty te pozwalają na utrzymywanie niższego poziomu kapitału własnego, który, mimo że charakteryzuje się minimalizowaniem ryzyka upadłości (Flannery, 2009), jest dla banku bardzo drogi. Obligacje CoCo cechują się również systemem motywacyjnym dla akcjonariuszy i zarządu banków. Tym pierwszym uświadamiają, że w razie problemów z wypłacalnością, proces konwersji przyniesie dodatkowy kapitał akcyjny, który rozwodni dotychczasowy kapitał i spowoduje utratę pakietów większościowych (Calomiris, 2012). Z kolei dla zarządu kolejne emisje CoCo bonds mogą oznaczać zwiększoną dyscyplinę rynkową (NBP, 2015). Rozwiązanie to nie jest jednak pozbawione wad. Zaliczyć do nich można przede wszystkim możliwość rolowania długu i kolejnych emisji tego typu obligacji (Murphy i in., 2012), co w sytuacji, gdy potencjalni inwestorzy dostrzegą sygnały oznaczające konieczność konwersji CoCo bonds, może powodować, że nie będą zainteresowani kupnem następnej emisji (Małek i Szelągowska, 2018). Co więcej, instrumenty te charakteryzują się dużą ingerencją w prawa wierzycieli, co może skutkować negatywnie na rynek danej kategorii dłużnych papierów wartościowych (NBP, 2015).

Tabela 1 przedstawia wartość wyemitowanych obligacji zamiennych typu CoCos w krajach europejskich w latach 2000-2018 i pokazuje, że emitentami obligacji warunkowo zamiennych w Europie są głównie kraje skandynawskie oraz zachodnie. Wśród nich największymi emitentami są Francja (ok. 34\% całości europejskiej emisji) i Wielka Brytania (ok. 29\% emisji). 
Ta be la 1. Emisja obligacji typu CoCo w Europie w latach 2000-2018

\begin{tabular}{|l|c|c|}
\hline \multicolumn{1}{|c|}{ Kraj } & $\begin{array}{c}\text { Wartość wyemitowanych CoCos } \\
\text { (w EUR) }\end{array}$ & $\begin{array}{c}\text { Udzial } \\
\text { w emisji europejskiej (w \%) }\end{array}$ \\
\hline Austria & 2937110888,32 & 1,30 \\
\hline Belgia & 2068678292,46 & 0,92 \\
\hline Cypr & 529546635,85 & 4,49 \\
\hline Dania & 10125547777,85 & 2,75 \\
\hline Finlandiaia & 6197653034,39 & 33,61 \\
\hline Francja & 75874899109,63 & 2,50 \\
\hline Niemcy & 5652772902,20 & 7,17 \\
\hline Włochy & 16180567378,88 & 2,66 \\
\hline Holandia & 6015584342,60 & 0,14 \\
\hline Norwegia & 317969343,31 & 0,30 \\
\hline Portugaliaia & 675777818,06 & 5,95 \\
\hline Hiszpania & 13424909441,85 & 2,09 \\
\hline Szwecja & 4715184624,57 & 7,53 \\
\hline Szwajcaria & 17002787368,93 & 28,36 \\
\hline Wielka Brytania & 64024125581,32 & \\
\hline
\end{tabular}

Źródło: Thomson Reuters.

Ry s u n e 1. Wartość emisji CoCos banków europejskich w latach 2000-2018 w euro

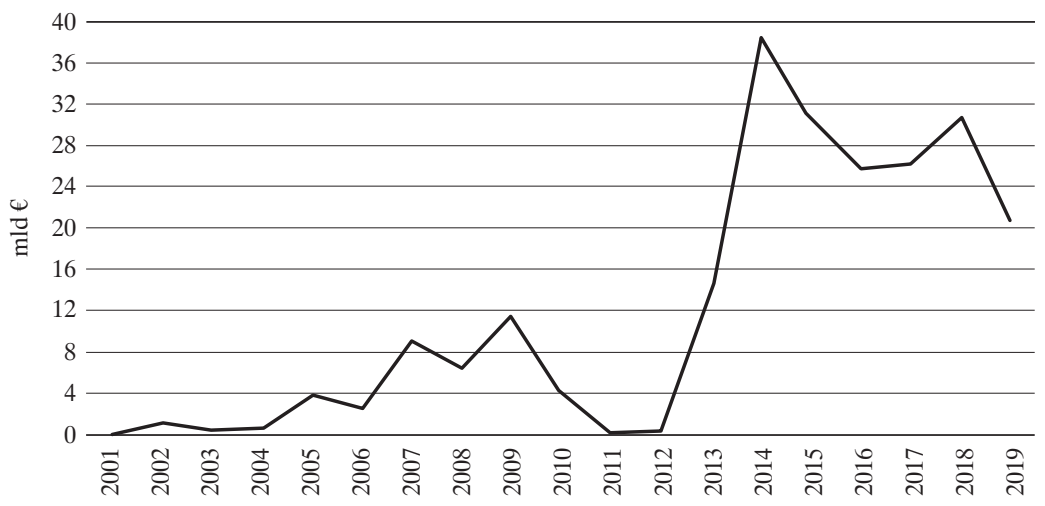

Źródło: Thomson Reuters. 
Rysunek 1 przedstawia wartość emisji obligacji typu contingent covertibles w bankach europejskich w latach 2000-2018. Analiza wykresu na rysunku 1 wskazuje, że rynek obligacji warunkowo zamiennych ma tendencję rosnącą, a punkt kulminacyjny nastąpił w roku 2014, kiedy to emisja wyniosła ok. 39 mld euro. Zdecydowanie drugie dziesięciolecie XXI wieku sprzyjało rozwojowi CoCos w Europie.

\section{Badania nad obligacjami typu CoCo}

Stosowanie obligacji zamiennych typu contingent convertibles jest mechanizmem stosunkowo młodym. W historii tych instrumentów za ważny uznaje się rok 2009, kiedy to Lloyd's wyemitował CoCo bonds po raz pierwszy. Na podstawie przeprowadzonego przeglądu literaturowego, przy jak najlepszej wiedzy Autorki, dotychczasowe badania dotyczące obligacji zamiennych typu contingent convertibles skupiały się głównie na aspektach dotyczących istoty ich emisji w kontekście alternatywnego źródła finansowania banków komercyjnych (zob. Hau i Hrasko, 2018; Herring i Calomiris, 2011; Liberadzki i Liberadzki, 2016; 2017; Jang i in., 2018; Avdijev i in., 2015; Williams i in., 2018; Małek i Szelągowska, 2018). Istnieje zatem luka badawcza w zakresie badania determinantów emisji CoCos, która skłoniła Autorkę do podjęcia wspomnianego tematu badawczego.

Badania dotyczące banków, które finansowały się kapitałem własnym, a także kapitałem warunkowym złożonym $\mathrm{z}$ obligacji typu contingent convertibles przeprowadzone zostały przez K. Liberadzkiego, M. Liberadzkiego i P. Jaworskiego. Badacze ci zbudowali model ekonometryczny, który miał za zadanie określić jak obligacje CoCos wpływają na wypłacalność banku z punktu widzenia regulatora. Wypłacalność w badaniu interpretowana była jako nadwyżka likwidacyjnej wartości aktywów (proces bogactwa) nad wartością długu wymagalnego przez wierzycieli w sytuacji upadłości banku (proces długu). Autorzy, poprzez porównanie emisji obligacji typu CoCo z emisją zwykłych bankowych obligacji, zauważyli znaczące różnice dla okresów koniunktury i dekoniunktury w cyklach gospodarczych. W momentach określanych jako kryzysy gospodarcze, obligacje warunkowo zamienne CoCo pozytywnie oddziaływały na wspomnianą nadwyżkę banków, dzięki zastosowaniu mechanizmu konwersji długu na kapitał regulacyjny AT1. Taki proces, mimo złych warunków gospodarczych, które z natury zagrażają stabilności instytucji finansowych, pozytywnie wpływał na adekwatność kapitałą banków. W sytuacjach dobrej koniunktury, która sprzyja zachowaniu stabilności finansowej w bankach, obligacje $\mathrm{CoCo}$ negatywnie wpływają na utrzymywaną przez bank nadwyżkę. Jest 
to skutek wysokości płaconego kuponu, który w porównaniu z obligacjami zwykłymi jest dużo wyższy (Jaworski i in., 2015). Przeprowadzone badanie wskazuje, że istnieje związek między wpływem emisji obligacji warunkowo zamiennych na adekwatność kapitałową banków a fazami cyklu koniunkturalnego.

Inne interesujące z punktu widzenia bankructwa banku badanie przeprowadzone zostało przez J. Hilschera i A. Raviva. Autorzy zbadali i porównali prawdopodobieństwo ogłoszenia upadłości przez bank przy trzech scenariuszach:

1) bank finansuje się tylko i wyłącznie za pomocą kapitału własnego;

2) bank finansuje się nie tylko kapitałem własnym, lecz także długiem podporządkowanym;

3) bank finansuje się kapitałem własnym, ale również za pomocą emisji obligacji warunkowo zamiennych $\mathrm{CoCo}$.

Najbardziej interesujący wniosek z badania, który porównywał scenariusz 1 z 3 wskazywał, że bank, który emituje obligacje typu CoCo cechuje się takim samym prawdopodobieństwem upadłości, jak bank finansujący się wyłącznie kapitałami własnymi. Udowodniono jednak, że instrumenty obligacji contingent convertibles wpływały na ograniczenie presji akcjonariuszy na zarząd banku oraz skutecznie ograniczały skłonność do ryzyka zarządu banku. Ostatnie zjawisko można wytłumaczyć faktem, że wraz ze wzrostem potencjalnego ryzyka w działalności banku, zwiększa się prawdopodobieństwo zaistnienia konwersji długu na kapitał akcyjny, co wpływa na spadek atrakcyjności akcji dla potencjalnych inwestorów (Hilsher i Raviv, 2012).

Badaczami, którzy również analizowali wpływ emisji obligacji CoCos na ryzyko upadłości banków komercyjnych byli H. Hau i G. Hrasko, którzy w swoim badaniu spróbowali odpowiedzieć na pytanie, czy emisja obligacji warunkowo zamiennych wpływa tak samo na zmniejszenie ryzyka bankructwa banku, jak powiększenie kapitału własnego w formie emisji nowych akcji. Weryfikacja hipotezy nastąpiła poprzez analizę obniżki spreadów na swapach ryzyka kredytowego (CDS), która miała miejsce przy ogłoszeniach emisji. Wyniki przeprowadzonego badania pokazały, że generalnie obligacje typu CoCo nie osiaggają takiego samego poziomu ograniczenia ryzyka upadku i niewykonania zobowiązań przez bank, jak równoważny nominalnie kapitał własny składający się z akcji. Jednakże, cechy konstrukcyjne obligacji warunkowo zamiennych mają duży wpływ na stopień redukcji ryzyka. Największy, porównywalny do kapitału własnego, poziom redukcji ryzyka niewykonania zobowiązań przez bank mają te obligacje $\mathrm{CoCo}$, które w pełni przekształcają się na kapitał i na stałe umarzają dług. W przypadku innych cech konstrukcyjnych obligacji warunkowo zamiennych, poziom redukcji ryzyka jest znacznie niższy (Harald i Hrasko, 2018). 
Badaczami, którzy próbowali zbadać, dlaczego banki komercyjne decydują się na emisję obligacji typu CoCos byli B. Williams, S.L. Tan I J.-P. Fench. Autorzy udowodnili, że głównym powodem emisji CoCos jest poziom ryzyka systemowego banku, a chęć zwiększenia zysków odgrywa w emisji znacznie mniejszą rolę. Duża emisja CoCos przez banki znaczące systemowo jest jednym z rozwiązań zjawiska banków to big to fail, gdyż w ten sposób zmniejszone jest prawdopodobieństwo ratowania ich kosztem podatników. Autorzy ukazali również, że emisja obligacji warunkowo zamiennych bez rekomendacji nadzoru, daje sygnał ostrzegawczy dla organów regulacyjnych odnośnie do sytuacji stabilności finansowej w banku, co wymaga dalszej kontroli (Williams i in., 2017).

Inną perspektywę badań na temat rynku emisji obligacji typu contingent convertibles przedstawili S. Avdjiev, P. Bolton, W. Jiang, B. Bogdanova oraz A. Kartasheva, którzy w przeprowadzonych analizach udowodnili, że głównymi emitentami $C o C o s$ są duże banki o względnie wystarczającej bazie kapitałowej. Emisja CoCos prowadzi średnio do 8 punktów bazowych spadku na spreadach CDS, co wskazuje na skuteczną reedukację ryzyka kredytowego banku. Udowodniono również, że nie ma znaczącego wpływu między emisją contingent convertible bonds a ceną akcji ich emitentów (Avdijev i in., 2015).

\section{Dane i metodologia badawcza}

Celem badania jest zidentyfikowanie, które ze wskaźników zaliczanych do grupy CAMEL determinują banki komercyjne do emisji obligacji typu contingent convertibles. Próba badawcza obejmuje 65 europejskich banków komercyjnych z łącznie 15 krajów, tj.: Austrii, Belgii, Cypru, Danii, Finlandii, Francji, Niemiec, Włoch, Holandii, Norwegii, Portugalii, Hiszpanii, Szwecji, Szwajcarii i Wielkiej Brytanii. W celu weryfikacji hipotezy zebrano dane finansowe ze sprawozdań finansowych banków komercyjnych z bazy Thomson Reuters w ujęciu kwartalnym dla lat 2000-2018, które posłużyły do obliczenia odpowiednich wskaźników.

Hipoteza przyświecająca badaniu zakłada, że czynniki CAMEL wpływają istotnie statystycznie na emisję obligacji $\mathrm{CoCo}$ przez europejskie banki komercyjne. Przez CAMEL należy rozumieć grupy determinant: adekwatności kapitałowej (capital adequancy), jakości aktywów (assets quality), jakości zarządzania (management quality), efektywności (efficiency) oraz płynności 
(liquidity). W niniejszym badaniu wspomniane grupy wskaźników reprezentują odpowiednio: relacja kapitału Tier1 do aktywów ważonych ryzykiem (tier1), udział kredytów niepracujących w sumie udzielonych kredytów $(n p l)$, udział aktywów pracujących w sumie bilansowej (manage), wskaźnik efektywności rozumiany jako udział kosztów nieodsetkowych w dochodach ogółem (eff) oraz udział aktywów płynnych w sumie bilansowej (liquid). Za zmienną zależną wybrano udział wartości wyemitowanych obligacji warunkowo zamiennych CoCos w sumie bilansowej (coco).

Wskaźniki CAMEL są często używane w badaniach przez wielu autorów specjalizujących się w finansach i bankowości. P. Chodnicka-Jaworska (2017) badała istotność wpływu determinant CAMEL w procesie nadawania noty ratingowej bankom europejskim przez trzy największe agencje ratingowe. Badanie R. Alton Gilbert, Andrew P. Meyer i Mark D. Vaughan skupiało się wokół analizy potencjalnego wkładu w nadzór bankowy modelu zaprojektowanego na bazie CAMEL w celu przewidywania, które banki będą miały obniżone oceny nadzorcze w przyszłych okresach (Gilbert i in., 2000). Również wielu badaczy używało grupy wskaźników CAMEL do analizy i oceny sytuacji finansowej banków komercyjnych w sektorze bankowym danego kraju, ze względu na obszerny potencjał informacyjny analizowanych wskaźników odnośnie do wielu obszarów funkcjonowania instytucji finansowych. Takie podejście reprezentowali Mahdi Bastan, Mohammad Bagheri Mazraeh, Ali Mohammad Ahmadvand, którzy analizowali sytuację banków w Iranie (Ahmadvand i in., 2016) oraz Sushendra Kumar Misra i Parvesh Aspal, których badanie skupiało się na wykorzystaniu wskaźników CAMEL do oceny finansowej Grupy State Bank (Parvesh, 2012).

Do weryfikacji hipotezy badawczej skorzystano z regresji danych panelowych, z których zbudowano model statyczny, wykorzystywany w wielu badaniach do analizy danych czasowo-przekrojowych. W celu podjęcia decyzji o użyciu modelu z efektami stałymi lub losowymi posłużono się testem Hausmana, którego hipoteza zerowa zakłada, że efekty grupowe są nieskorelowane ze zmiennymi objaśniającymi, a więc poprawny jest model z dekompozycją składnika losowego. Dokonano także testu mnożnika Lagrange'a zaproponowanego przez Breuscha-Pagana, który służył dokonaniu wyboru pomiędzy modelami z efektami losowymi a regresją liniową przy użyciu metody najmniejszych kwadratów. 


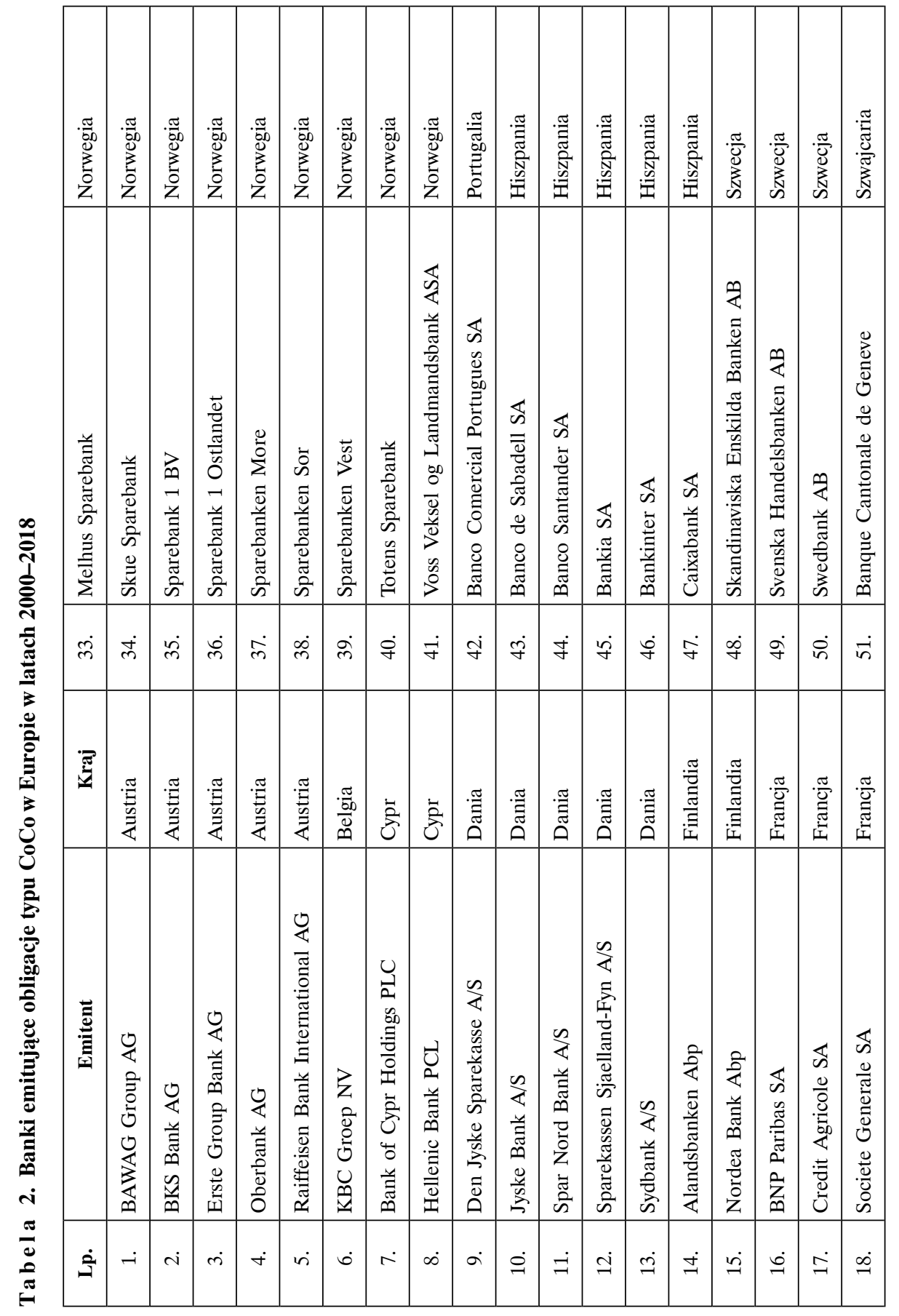




\begin{tabular}{|c|c|c|c|c|c|c|c|c|c|c|c|c|c|}
\hline 莺 & 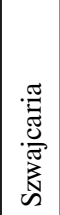 & 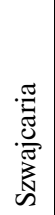 & 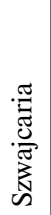 & 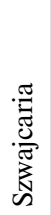 & 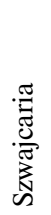 & 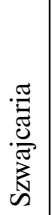 & 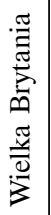 & 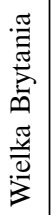 & 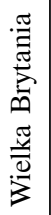 & 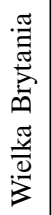 & 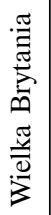 & 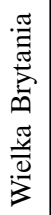 & 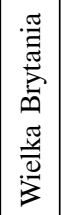 \\
\hline 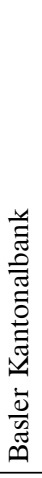 & 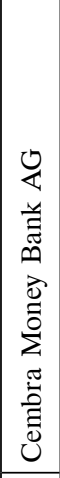 & 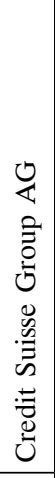 & 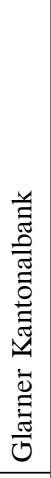 & 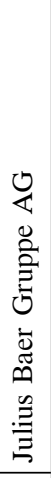 & 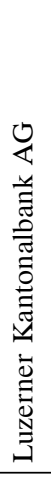 & 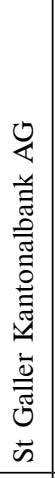 & 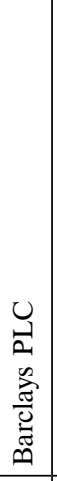 & $\begin{array}{l}U \\
\underline{a} \\
0 \\
0 \\
0 \\
0\end{array}$ & 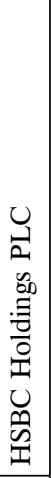 & 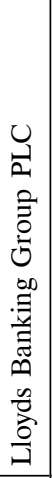 & 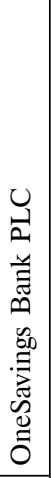 & 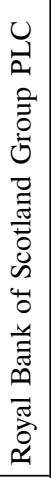 & 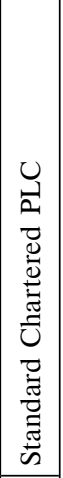 \\
\hline กี่ & $\dot{n}$ & $\dot{n}$ & $\dot{n}$ & $\ddot{n}$ & in & $\stackrel{\infty}{n}$ & in & $\dot{8}$ & $\dot{\sigma}$ & ชู่ & $\dot{3}$ & $\dot{0}$ & $\dot{b}$ \\
\hline 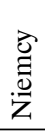 & 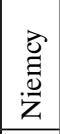 & 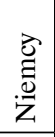 & 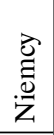 & 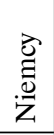 & $\begin{array}{l}\overrightarrow{\vec{v}} \\
\overline{0} \\
\overrightarrow{3}\end{array}$ & $\begin{array}{l}\frac{\lambda}{0} \\
\frac{0}{3}\end{array}$ & $\frac{\overrightarrow{3}}{\frac{0}{0}}$ & $\frac{\frac{2}{0}}{\frac{0}{3}}$ & $\begin{array}{l}\frac{\vec{z}}{0} \\
\frac{0}{3}\end{array}$ & 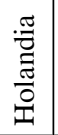 & 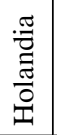 & $\begin{array}{l}\cdot \frac{\pi}{b D} \\
0 \\
0 \\
0 \\
z \\
z\end{array}$ & $\begin{array}{l}\frac{\pi}{00} \\
\infty \\
\sum_{0}^{\infty} \\
z\end{array}$ \\
\hline 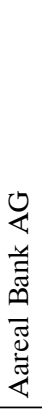 & 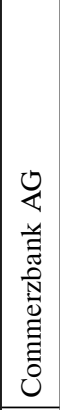 & 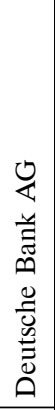 & 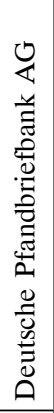 & 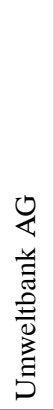 & 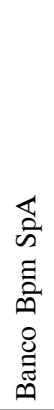 & 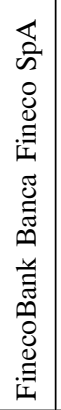 & 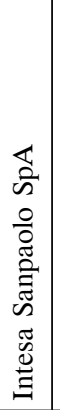 & 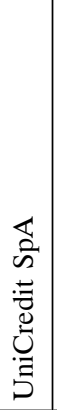 & 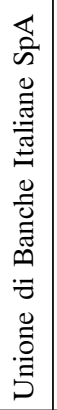 & 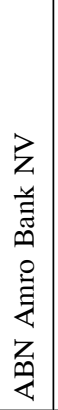 & $\begin{array}{l}\vec{Z} \\
2 \\
0 \\
0 \\
0 \\
0 \\
Z\end{array}$ & 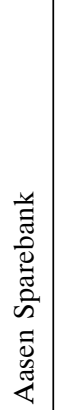 & 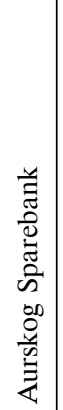 \\
\hline 2 & $\dot{\overbrace{}}$ & $\vec{\sim}$ & तi & $\tilde{\lambda}$ & $\stackrel{\mathbb{N}}{\Delta}$ & $\approx$ & $\stackrel{\sim}{\circ}$ & $\tilde{\imath}$ & $\stackrel{\sim}{\sim}$ & $\ddot{\mathrm{\lambda}}$ & 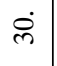 & $\vec{m}$ & लें \\
\hline
\end{tabular}


Uogólniony wzór modelu, który został zastosowany do weryfikacji hipotezy badawczej ma postać:

$$
y_{j, t}=\sum_{k=0}^{n} \beta_{k} x_{j, t}+\theta_{t} T_{t}+\mu_{j}+\varepsilon_{j, t},
$$

gdzie:

$y_{j, t}$ - udział emisji obligacji typu CoCos w sumie bilansowej banku $j \mathrm{w}$ czasie $t$; $x_{j, t}-$ wektor zmiennych niezależnych dotyczących $j$-tego banku w czasie $t$, tj.:

$$
x_{j, t}=\left[\operatorname{tier}_{j, t} ; \operatorname{npl}_{j, t} ; \operatorname{manage}_{j, t} ; \operatorname{eff}_{j, t} ; \operatorname{liquid}_{j, t,}\right]
$$

gdzie:

tier $1_{j, t}$ - relacja kapitału Tier1 do aktywów ważonych ryzykiem, $\mathrm{npl}_{j, t}$ - udział kredytów niepracujących w sumie udzielonych kredytów, manage $_{j, t}$ - udział aktywów pracujących w sumie bilansowej, eff $_{j, t}$ - wskaźnik efektywności rozumiany jako udział kosztów nieodsetkowych w dochodach ogółem,

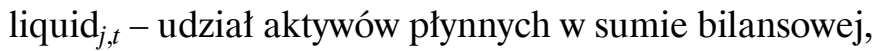
$\theta_{t}, T_{t}$ - efekty grupowe, $\mu_{j}$ - błąd zawierający stałe w czasie nieobserwowalne statystyki, $\varepsilon_{j, t}-$ błąd czysto losowy.

\section{Wyniki badań nad determinantami emisji CoCos przez banki europejskie}

Głównym celem przeprowadzonego badania było zweryfikowanie, które ze wskaźników metodologii CAMEL, determinują emisję obligacji typu contingent convertibles w bankach europejskich w latach 2000-2018. W tym celu zbudowano model ekonometryczny w oparciu o przeprowadzoną regresję kwartalnych danych panelowych dla 65 banków komercyjnych z krajów Europy. Wyniki przeprowadzonej estymacji przedstawia tabela 3 .

Otrzymane wyniki analizy wskazują, że wszystkie zmienne wyjaśniające wybrane do badania będące reprezentantami wskaźników według metodologii CAMEL, czyli: relacja kapitału Tier1 do aktywów ważonych ryzykiem, udział kredytów niepracujących w sumie udzielonych kredytów, udział aktywów pracujących w sumie bilansowej, wskaźnik efektywności rozumiany jako udział kosztów nieodsetkowych w dochodach ogółem oraz udział aktywów płynnych w sumie bilansowej, wpływają istotnie statystycznie na zmienną zależną reprezentowaną przez udział wartości emisji obligacji CoCos w sumie bilansowej banku. 
Ta b e la 3. Wyniki estymacji determinant emisji obligacji CoCos w bankach europejskich

\begin{tabular}{|l|c|c|c|}
\hline \multicolumn{1}{|c|}{ Zmienna } & Wspótczynnik & $\boldsymbol{t}$-Studenta & Wartość $\boldsymbol{p}$ \\
\hline Tier1 & 0,0224985 & 16,49 & 0,0000 \\
\hline Npl & 0,0149905 & 10,34 & 0,0000 \\
\hline Manage & 0,0015865 & 3,314 & 0,0009 \\
\hline Eff & 0,0009887 & 2,542 & 0,0111 \\
\hline Liquid & 0,0024511 & 3,272 & 0,0011 \\
\hline Const & $-0,00189869$ & $-8,688$ & 0,0000 \\
\hline Model & & FE \\
\hline Test Hausmana & \multicolumn{3}{|c}{0,0187894} \\
\hline Test Breuscha-Pagana & & 0,0000000 \\
\hline
\end{tabular}

Źródło: opracowanie własne.

Warty podkreślenia jest fakt, że każda zmienna niezależna pozytywnie oddziałuje na zmienną zależną, co oznacza, że wraz ze wzrostem o jednostkę każdej ze zmiennych wyjaśniających, zmienna wyjaśniana rośnie. Wniosek ten w odniesieniu do analizowanych wskaźników oznacza, że wraz ze wzrostem relacji wartości kapitału Tier1 w stosunku do wartości aktywów ważonych ryzykiem o $1 \%$, wartość utrzymywanych CoCos w sumie bilansowej rośnie średnio o 2,25\%. Taka zależność oznaczać może, że bank, który identyfikuje problemy z adekwatnością kapitałową nie tylko redukuje wartość utrzymywanych ryzykownych aktywów, lecz także powiększa utrzymywany kapitał Tier1. Podejrzenie problemu niewystarczalności kapitałów własnych i w konsekwencji niewypłacalności mobilizuje banki do emisji obligacji $C o C o s$, które w przyszłości pod wpływem konwersji długu na kapitał AT1, mogą uratować bank przed bankructwem.

Analogicznie, wraz ze wzrostem udziału kredytów niepracujących w sumie udzielonych kredytów o 1\%, wartość utrzymywanych CoCos w sumie bilansowej rośnie średnio o $1,50 \%$. Taki związek może być tłumaczonym faktem, że bank, który identyfikuje wzrost kredytów zagrożonych w swoim portfelu jest świadomy, że urzeczywistnione w ten sposób ryzyko kredytowe kredytobiorcy może przełożyć się na problemy z wypłacalnością wskutek nieodzyskanych udzielonych środków pieniężnych. Fakt ten motywuje banki do emisji obligacji CoCos, które w razie niedostatku środków na pokrycie zobowiązań posłużą jako dodatkowy kapitał. 
Zmienna zależna rośnie również wraz ze wzrostem udziału aktywów pracujących w sumie bilansowej o $1 \%$. Wówczas wartość utrzymywanych CoCos w sumie bilansowej rośnie średnio o $0,16 \%$. Często wzrostowi utrzymywanych aktywów pracujących towarzyszy wzrost aktywów o wyższym poziomie ryzyka. Dlatego też bank musi zabezpieczać się przed potencjalnym ryzykiem kredytowym kontrahenta i kredytobiorcy, które może przerodzić się w ryzyko niewypłacalności. W tym celu emituje obligacje typu CoCos, aby w razie zidentyfikowania problemów i zagrożenia upadłością zamienić je na kapitał, z którego może pokryć ewentualne zobowiązania.

Pozytywny związek można zauważyć wraz ze wzrostem udziału kosztów nieodsetkowych w dochodach ogółem. Gdy rosną one o 1\%, wartość utrzymywanych CoCos w sumie bilansowej rośnie średnio o 0,09\%. Taka zależność może zostać wytłumaczona przez fakt, że rosnący udział kosztów w dochodach ogólem powoduje zmniejszanie wyniku finansowego banku, a więc dostępność wolnych środków pieniężnych spada. W dłuższym horyzoncie czasu, przy założeniu, że tempo wzrostu kosztów jest wyższe niż tempo wzrostu dochodów banku, sytuacja ta może doprowadzić do problemów z brakiem wystarczającej ilości kapitałów do pokrywania zobowiązań banku, co w konsekwencji może skutkować zakłóceniem stabilności finansowej banku i jego upadłością.

Także udział aktywów płynnych w sumie bilansowej wpływa pozytywnie na zmienną zależną. Wzrost tego wskaźnika o $1 \%$, powoduje, że wartość utrzymywanych CoCos w sumie bilansowej rośnie średnio o 0,25\%. Jest to najbardziej zaskakujący wniosek z całej analizy, gdyż przypuszczalnie wraz ze wzrostem posiadanej płynności, bank może akumulować jej zapasy, zapewniając sobie w ten sposób finansowanie na przyszłość. Zdecydowana część płynności banku wykorzystywana jest jednak na wypłaty depozytów oraz udzielanie pożyczek pieniężnych. Będąc świadomym, że środki te są szybko przekazywane do innych podmiotów, bank zapewnia sobie bezpieczeństwo poprzez emisję CoCos, która w razie problemów z wypłacalnością zastąpi posiadany w bilansie dług na kapitał podstawowy.

\section{Wnioski}

Niniejszy artykuł skupia się na temacie ryzyka upadłości banków komercyjnych poprzez analizę instrumentu hybrydowego, jakim jest obligacja contingent convertibles, która swoje uregulowanie prawne znajduje w dyrektywie dotyczącej restrukturyzacji i uporządkowanej likwidacji banków, tzw. Resolution. Akt ten, który ma okazać się kołem ratunkowym dla upadających instytucji finansowych, podkreśla konieczność zastosowania koncepcji bail-in, czyli przeniesienia 
skutków upadłości banku na akcjonariuszy i wierzycieli. W ramach tego zjawiska dyrektywa zawiera przepis dotyczący możliwości konwersji długu na kapitał akcyjny, który odbywać się może za pomocą obligacji warunkowo zamiennych, tzw. CoCo bonds.

Głównym celem niniejszego artykułu było zweryfikowanie postawionej hipotezy badawczej, iż wskaźniki CAMEL, reprezentujące takie obszary banku komercyjnego, jak: adekwatność kapitałowa, jakość aktywów, jakość zarządzania, efektywność i płynność, wpływają istotnie statystycznie na emisję obligacji CoCo. Weryfikacja hipotezy odbyła się za pomocą regresji danych panelowych dla 65 banków notowanych na europejskich giełdach papierów wartościowych w okresie od 2000 do 2018 roku. Zebrane do badania dane pochodzily z bazy danych Thomson Reuters.

Otrzymane wyniki z przeprowadzonego badania wskazują, że każdy ze wskaźników metodologii CAMEL, a zatem: relacja kapitału Tier1 do aktywów ważonych ryzykiem (adekwatność kapitałowa), udział kredytów niepracujących w sumie udzielonych kredytów (jakość aktywów), udział aktywów pracujących w sumie bilansowej (jakość zarządzania), wskaźnik efektywności rozumiany jako udział kosztów nieodsetkowych w dochodach ogółem (efektywność), udział aktywów płynnych w sumie bilansowej (płynność), istotnie statystycznie oddziałuje na emisję obligacji typu contingent convertibles, przy czym kierunek tego oddziaływania jest dodatni. Przeprowadzone rozumowanie wskazuje, że główną przyczyną do emisji CoCos jest zabezpieczenie się europejskich banków komercyjnych przed ewentualną utratą wypłacalności, która w dłuższej perspektywie czasu może doprowadzić do upadku instytucji finansowej.

\section{Bibliografia}

Admati, A. i Hellwig, M. (2013). The Bankers' New Clothes. What's Wrong with Banking and What to Do About It. New Jersey: Princeton University Press.

Ahmadvand, A., Bastan, M. i Bagheri Mazrae, M. (2016). Dynamics of banking soundness based on CAMELS rating system. Pozyskano z https://pdfs.semanticscholar.org/bd06/8411a62d1c4378b7172a071c6c20a7e4a8a6.pdf?_ga =2.22392379.1406865918.1585077092570325925.1585077092.

Avdjiev, S., Bolton, P., Jiang, W., Kartasheva, A. i Bogdanova, B. (2015). CoCo Bond Issuance and Bank Funding Costs. Conference on Financial Regulation. Becker Friedman Institute. University of Chicago October.

Calomiris, C.W. (2012). How to Regulate Bank Capital. National Affairs, 43, Spring. Pozyskano z https://www.nationalaffairs.com/publications/detail/how-to-regulate-bank-capital.

Chodnicka-Jaworska, P. (2017). CAMEL - ocena ryzyka w estymacji ratingów banków europejskich. Studia Ekonomiczne. Wspótczesne Finanse, 10(339).

Corrigan, G. (2006). Remarks At the Symposium on Risk Reduction In Payment and Settlement Systems. New York: Goldman Sachs and Co. 
Dyrektywa Parlamentu Europejskiego i Rady 2014/59/UE z dnia 15 maja 2014 r. ustanawiająca ramy na potrzeby prowadzenia działań naprawczych oraz restrukturyzacji i uporządkowanej likwidacji w odniesieniu do instytucji kredytowych i firm inwestycyjnych oraz zmieniająca dyrektywę Rady 82/891/EWG i dyrektywy Parlamentu Europejskiego i Rady 2001/24/WE, 2002/47/WE, 2004/25/WE, 2005/56/WE, 2007/36/WE, 2011/35/UE, 2012/30/UE i 2013/36/EU oraz rozporządzenia Parlamentu Europejskiego i Rady (UE) nr 1093/2010 i (UE) nr 648/2012.

European Commission. (2012). Commission Staff Working Paper, Autumn 2012 Update, COM (2012) 778 final, s. 28-32.

Flannery, M.J. (2010). Stabilizing Large Financial Institutions with Contingent Capital Certificates. Quarterly Journal of Finance, 6(2). https://doi.org/10.1142/S2010139216500063.

Gilbert, R., i Meyer, A. i Vaughan, M. (2000). The role of a CAMEL downgrade model in bank surveillance. Federal Reserve Bank of St. Louis Working Papers 2000-021A. Pozyskano z https://pdfs.semanticscholar.org/2339/ebd62c9bd9598a034ee0556427f6544996e6.pdf.

Haldane, A. (2012).We should Go Further Unbundling Banks. Financial Times, 3 October. Pozyskano z https://www.bankofengland.co.uk/article/2012/we-should-go-further-unbundling-banks.

Harald, H. i Hrasko, G. (2018). Are CoCo Bonds a Good Substitute for Equity? Evidence from European Banks. Swiss Finance Institute, Research Paper Series, No. 18-67.

Hilsher, J. i Raviv, A. (2012). Bank Stability and Market Discipline: The Effect of Contingent Capital on Risk Taking and default Probability. Working Paper Series, Brandies University.

Iwanicz-Drozdowska, M. (2015). Jak kosztowny okazał się bail-out. W: M. Iwanicz-Drozdowska (red.), Restrukturyzacja banków w Unii Europejskiej w czasie globalnego kryzysu finansowego. Warszawa: Oficyna Wydawnicza Szkoły Głównej Handlowej.

Jaworski, P., Liberadzki, K. i Liberadzki, M. (2015). Regulatory and Economic Incentives for Issuing Contingent Convertibles. SSRN Electronic Journal. htpps://doi.org/10.2139/ ssrn.2638279.

Liberadzki, K. i Liberadzki, M. (2016). Konstrukcja, zasady emisji i wycena hybrydowych papierów wartościowych na eurorynku. Warszawa: Oficyna Wolters Kluwer Business.

Liberadzki, K. i Liberadzki, M. (2016). O konieczności wprowadzenia w polskim prawie możliwości emitowania przez banki papierów wartościowych typu contigent convertible. Bezpieczny Bank, Bankowy Fundusz Gwarancyjny, 1(62).

Małek, M. i Szelągowska, A. (2018), Wykorzystanie obligacji typu CoCo w dynamicznej regulacji instytucji sektora bankowego. Studia Ekonomiczne, Zeszyty Naukowe Uniwersytetu Ekonomicznego w Katowicach, 370.

Murphy, G., Walsh, M. i Willison, M. (2012). Precautionary Contingent Capital. Financial Stability Paper, No. 16, Bank of England.

NBP. (2015). Resolution, czyli nowe podejście do banków zagrożonych upadtością. Warszawa: Narodowy Bank Polski.

Parvesh, S. (2012). A CAMEL Model Analysis of State Bank Group. SSRN Electronic Journal. htpps://doi.org/10.2139/ssrn.2177081.

Penacchi, G., Vermaelen, T. i Wolff, C.C.P. (2013). Contingent Capital: The Case of COERCed. Journal of Financial and Quantitative Analysis, 49(3), 541-574.

Rozporządzenie Parlamentu Europejskiego i Rady (UE) z dn. 26.06.2019 r. w sprawie wymogów ostrożnościowych dla instytucji kredytowych i firm inwestycyjnych.

Williams, B., Tan, S.L. i Fench, J.P. (2018). Why do banks issue Contingent Convertibe Bonds? CFS Working Paper Series, No. 586. 


\title{
Rozdział 3
}

\author{
JACEK KARASIŃSKI*
}

\section{Wpływ światowego kryzysu finansowego 2008 na efektywność europejskich rynków akcji}

Celem artykułu jest odpowiedź na pytanie, czy światowy kryzys finansowy 2008 negatywnie wpłynął na efektywność wybranych europejskich rynków akcji w formie słabej. Badanie zostało przeprowadzone dla 13 wybranych indeksów uwzględniających wszystkie akcje notowane na różnych europejskich giełdach w latach 2005-2018. Przeprowadzono trzy różne testy normalności rozkładów stóp zwrotu, aby zweryfikować czy w okresie kryzysu odsetek rynków efektywnych zmalał. Testy przeprowadzono dla każdego indeksu w każdym roku, każdym dwuletnim podokresie oraz dla 1, 2, 3 i 4-dniowych interwałów stóp zwrotu. Badanie nie pozwala jednoznacznie stwierdzić, że światowy kryzys finansowy 2008 negatywnie wpłynął na analizowane rynki akcji z uwagi na to, że niższe odsetki rynków efektywnych w formie słabej pojawiały się nie tylko w latach kryzysu. Dodatkowo odsetek rynków efektywnych w 2009 roku, tj. w roku następującym po eskalacji kryzysu, gwałtownie wzrósł, osiągając jeden z najwyższych poziomów w całym okresie badawczym.

Słowa kluczowe: kryzys, efektywność w formie słabej, rynki akcji.

\section{The Impact of the 2008 Global Financial Crisis on the Efficiency of the European Stock Markets}

The purpose of this article is to answer a question whether the 2008 global financial crisis negatively affected the weak-form efficiency of selected European stock markets. The study was conducted for 13 selected all-share stock indexes from different European stock exchanges in the years 2005-2018. In order to verify whether the percentage of the efficient markets decreased over the crisis period, 3 different tests of normality of the market returns' distribution were performed. The tests were conducted for each index in each year and for each 2-year sub-period for 1, 2,

\footnotetext{
mgr Jacek Karasiński - Wydział Zarządzania, Uniwersytet Warszawski, ul. Szturmowa 1/3, 02-678 Warszawa, Polska; e-mail: jkarasinski@wz.ue.edu.pl; https://orcid.org/0000-0003-43265044.
} 
3 and 4-day returns' intervals. The study does not allow for stating unambiguously that the 2008 global financial crisis negatively affected the stock markets analyzed as the lower percentages of the weak-form efficient markets did not only appear in the crisis-related period. Additionally, the percentage of the efficient markets in 2009, i.e. right after the escalation of the crisis, recovered rapidly, reaching one of the highest results in a whole research period.

Keywords: crisis, weak-form efficiency, stock markets.

JEL: G10, G12, G14

\section{Wprowadzenie}

Ogólnoświatowy kryzys finansowy 2007-2008, nazywany powszechnie w literaturze mianem globalnego kryzysu finansowego 2008, pociagnął za sobą wiele konsekwencji dla globalnej ekonomii. Jednym z nich był nagły spadek cen aktywów na światowych rynkach. Globalny kryzys finansowy 2008, zapoczątkowany na rynku kredytowym w USA, szybko rozprzestrzenił się na inne rynki, stając się największą globalną recesją od czasu Wielkiego kryzysu zapoczątkowanego w 1929 roku (Anagnostidis, Varsakelis i Emmanouilides, 2016). Według szacunków Losera (2009) ogólnoświatowy kryzys finansowy 2008 przyczynił się do spadku globalnego PKB o około $1 \%$.

Analiza efektywności rynków akcji jest ważna dla inwestorów z punktu widzenia zarówno zarządzania portfelem, jak i prognozowania cen oraz dla tworzących regulacje z punktu widzenia prowadzonej polityki i ustanawianych regulacji. Efektywność informacyjna podnosi ufność inwestorów w stosunku do rynków. Uodparnia ona również rynki na zewnętrzne wstrząsy (Mensi, Tiwari i Al-Yahyaee, 2019). Bezsprzecznie globalny kryzys finansowy 2008 stanowił test dla wspomnianej odporności światowych rynków finansowych.

Celem artykułu jest odpowiedź na pytanie, czy globalny kryzys finansowy 2008 negatywnie wpłynął na efektywność informacyjną wybranych europejskich rynków akcji w formie słabej. Przez negatywny wpływ kryzysu finansowego na efektywność informacyjną rynków w formie słabej w niniejszym badaniu rozumie się zmniejszony odsetek przypadków, w których badane rynki akcji były efektywne. Słaba forma efektywności jest jedną z trzech form efektywności informacyjnej rynków wyróżnionych przez Famę (1970). Dwie pozostałe to forma słabosilna oraz silna. Nawiązując do hipotezy efektywności rynku w formie słabej zaproponowanej przez Famę (1970) i Jensena (1978), bieżące ceny aktywów finansowych odzwierciedlają informacje historyczne oraz oczekiwania inwestorów. W rezultacie bieżące ceny zmieniają się losowo w sposób niemożliwy do ich przewidzenia (Kilon i Jamróz, 2015). Wielu badaczy nadal uznaje 
model błądzenia losowego zaproponowany przez Bacheliere'a w 1900 roku za synonim efektywności informacyjnej rynku w formie słabej. Jednocześnie model ten jest uznawany za rygorystyczny, jeśli chodzi o opisywanie dynamiki zmian cen aktywów finansowych. Model błądzenia zaproponowany przez Bacheliere'a mówi, że jeśli stopy zwrotu aktywa finansowego podlegają błądzeniu losowemu, to ich rozkład musi być normalny (Czekaj, 2014). Biorąc to pod uwagę, do analizy występowania efektywności informacyjnej w formie słabej zastosowano trzy różne testy normalności rozkładów, a mianowicie: test Lillieforsa, Shapiro-Wilka i D'Agostino-Pearsona. Wymienione testy normalności zostały przeprowadzone dla 13 wybranych, szerokich indeksów giełdowych uwzgledniających notowania wszystkich akcji kwotowanych na danym rynku w latach 2005-2018. Badane indeksy pochodzą z różnych europejskich giełd. Testy normalności rozkładów stóp zwrotu indeksów akcji zostały przeprowadzone dla interwałów 1, 2, 3 i 4-dniowych w każdym z lat okresu badawczego oraz w każdym z dwuletnich podokresów. Przyjęta hipoteza badawcza mówi, że globalny kryzys finansowy negatywnie wpłynął na efektywność informacyjną europejskich rynków akcji, co przejawiło się w niższym odsetku rynków efektywnych w okresie kryzysu w porównaniu z pozostałymi okresami. Niejednoznaczne wyniki innych badań poruszających tę problematykę uzasadniają podjęcie próby odpowiedzi na pytanie, czy globalny kryzys finansowy 2008 negatywnie wpłynął na efektywność informacyjną wybranych europejskich rynków akcji w formie słabej. Dodatkowym uzasadnieniem przeprowadzenia badania są jego unikalne założenia, jak:

- branie pod uwage jedynie szerokich indeksów uwzględniających wszystkie akcje notowane na danej giełdzie, czyli indeksów najlepiej oddających koniunkturę giełdową i odzwierciedlających ceny wszystkich notowanych na danym rynku aktywów;

- przeprowadzanie testów normalności rozkładów stóp zwrotu dla poszczególnych lat i dwuletnich okresów, a nie dla założonych z góry okien przedkryzysowych, kryzysowych i pokryzysowych, co jest powszechnie stosowane badaniach poruszających tę problematykę;

- zastosowanie rygorystycznych testów normalności rozkładów stóp zwrotu dla 4 różnych, lecz krótkich interwałów 1, 2, 3 i 4-dniowych.

Część druga artykułu poświęcona jest przeglądowi literatury dotyczącej wpływu kryzysu finansowego na efektywność informacyjną rynków finansowych w formie słabej. Część trzecia - prezentuje metodykę badania, czwarta zaś - przedstawia jego wyniki. Część piata poświęcona jest natomiast podsumowaniu wyników badania. 


\section{Przegląd literatury}

Na podstawie badania dotyczącego wpływu kryzysu finansowego 2008 na efektywność informacyjną w formie słabej 12 rynków akcji strefy euro, Anagnostidis, Varsakelis i Emmanouilides (2016) stwierdzili, że kryzys negatywnie wpłynął na efektywność informacyjną badanych rynków. Ponadto według badaczy kryzys doprowadził do powstania istotnych tendencji powrotu do średniej w ruchach cen akcji. Występowanie efektywności rynków akcji badane było z wykorzystaniem uogólnionego wykładnika Hursta. Podobne wyniki zostały zaprezentowane przez Sensoy’a i Tabaka (2015), którzy doszli do wniosku, że kryzys finansowy 2008 niekorzystnie wpłynął na większość rynków akcji w Unii Europejskiej. Wnioski, do jakich doszli w swoich badaniach Hort i in. (2014) również stały w zgodzie $\mathrm{z}$ wnioskami z dwóch przedstawionych wyżej badań. Badanie dotyczące europejskich, amerykańskich i japońskich rynków akcji wykazało, że globalny kryzys finansowy 2008 negatywnie wpłynął na efektywność informacyjną analizowanych rynków w formie słabej.

Odmienne wnioski z badania nad niemieckim i greckim rynkiem akcji zostały jednak przedstawione przez Katrisa i Daskalaki'ego (2013). Według badaczy analizowane rynki pozostały efektywne $\mathrm{w}$ formie słabej również podczas kryzysu. W badaniu nad wschodzącymi rynkami europejskimi Smith (2012) przedstawił nie tak jednoznaczne wyniki. Stwierdził on, że wpływ globalnego kryzysu finansowego 2008 na efektywność informacyjną był zależny od rynku. Singh, Deepak i Kumar (2015) przeprowadzili badanie na głównych i rozwijających się światowych rynkach. W badaniu wykorzystali testy pierwiastka jednostkowego oraz testy ilorazu wariancji. Badacze stwierdzili, że kryzys nie miał istotnego wpływu na efektywność informacyjną badanych rynków. Wnioski z badania przeprowadzonego przez Mensi'ego, Tiwari'ego i Yoona (2017) na 10 indeksach sektorowych islamskich rynków akcji wskazały natomiast na występowanie zmiennej w czasie efektywności. Niemniej jednak analizowane rynki stawały się mniej efektywne w trakcie kryzysu.

Studiując literaturę przedmiotu dotyczącą wpływu kryzysu finansowego na efektywność informacyjną rynków, łatwo jest znaleźć badania związane nie tylko z globalnym kryzysem finansowym 2008. Często można się również natknąć na badania dotyczące azjatyckiego kryzysu finansowego z lat 1997-1998. Wyniki badania przeprowadzonego przez Hoque'a i in. (2007) nie wykazały istotnego wpływu azjatyckiego kryzysu finansowego 1997-1998 na efektywność informacyjną $\mathrm{w}$ formie słabej większości z analizowanych azjatyckich rynków akcji. Kim i Shamsuddin (2006) doszli do podobnych wniosków, natomiast Cheong i in. (2007) do odmiennych. Ich badanie wykazało, 
że w okresie kryzysu efektywność informacyjna rynków w formie słabej była niższa. Podobnego zdania byli również Kian-Ping, Brooks i Kim (2007).

\section{Metodyka badania}

W celu przeprowadzenia analizy występowania słabej formy efektywności informacyjnej 13 wybranych europejskich rynków akcji wykorzystano trzy różne testy normalności rozkładów (test Lillieforsa, Shapiro-Wilka i D’Agostino-Pearsona). Każdy z testów zwraca wartość $p$, tj. tzw. prawdopodobieństwo testowe. $\mathrm{Z}$ uwagi na zróżnicowaną naturę zastosowanych testów wartości $p$ dla tych samych rozkładów mogą się między sobą różnić. Hipoteza zerowa przyjmowana w testach normalności rozkładów mówi, że rozkład danych empirycznych $F$ jest zgodny z rozkładem normalnym $N\left(\hat{u}, \hat{\sigma}^{\in}\right)$. Hipoteza zerowa odrzucana jest na rzecz hipotezy alternatywnej mówiącej, że rozkład danych empirycznych $F$ nie jest zgodny z rozkładem normalnym $N\left(\hat{u}, \hat{\sigma}^{\in}\right)$, gdy wartość $p$ jest mniejsza niż zadany poziom istotności $\alpha=0,05$. Powodem, dla którego zdecydowano się na wykorzystanie wyżej wymienionych testów normalności rozkładów był model błądzenia losowego zaproponowany przez Bacheliere’a w 1900 roku, opisujący stochastyczny proces zmian cen aktywów finansowych. Model zakłada, że jeśli stopy zwrotu aktywa finansowego podlegają błądzeniu losowemu, to ich rozkład musi być normalny (Czekaj, 2014). Mimo że wspominane założenie modelu wydaje się być zbyt rygorystyczne dla finansowych szeregów czasowych, szczególnie ze względu na często obserwowane grube ogony, model ten jest nadal często wykorzystywany w badaniach związanych z efektywnością informacyjną rynków w formie słabej.

Wymienione wyżej testy normalności zostały przeprowadzone dla rozkładów logarytmicznych stóp zwrotu 13 wybranych europejskich, szerokich indeksów giełdowych biorących pod uwagę akcje wszystkich spółek notowanych na danym rynku. Indeksy biorące udział w badaniu zostały przedstawione w tabeli 1.

Uwzględnione w badaniu szerokie indeksy giełdowe ${ }^{1}$ stanowią dobry wskaźnik ogólnej koniunktury giełdowej i, co ważniejsze z punktu widzenia przeprowadzonego badania, odzwierciedlają ceny wszystkich notowanych aktywów. Chęć uwzględnienia w badaniu jedynie szerokich indeksów akcji o wystarczająco długiej historii notowań doprowadziła jednak do wyselekcjonowania ograniczonej liczby rynków.

1 Brano pod uwagę wszystkie akcje notowane na danym rynku. 
Ta b e la 1. Wybrane europejskie, szerokie indeksy giełdowe biorące udzial w badaniu

\begin{tabular}{|r|l|l|l|}
\hline Lp. & \multicolumn{1}{|c|}{ Nazwa indeksu } & \multicolumn{1}{c|}{ Gietda } & \multicolumn{1}{c|}{ Kraj } \\
\hline 1 & AEX All-Share Index & Euronext Amsterdam & Holandia \\
\hline 2 & BEL All-Share Index & Euronext Brussels & Belgia \\
\hline 3 & CAC All-Share Index & Euronext Paris & Francja \\
\hline 4 & PSI All-Share Index & Euronext Lisbon & Portugalia \\
\hline 5 & ISEQ All-Share & Euronext Dublin & Irlandia \\
\hline 6 & PX-GLOB & Prague Stock Exchange & Republika Czeska \\
\hline 7 & OMX COPENHAGEN_PI & Nasdaq Copenhagen & Dania \\
\hline 8 & OMX HELSINKI_PI & Nasdaq Helsinki & Finlandia \\
\hline 9 & OMX STOCKHOLM_PI & Nasdaq Stockholm & Szwecja \\
\hline 10 & Classic All Share & Frankfurt Stock Exchange & Niemcy \\
\hline 11 & WIG & Warsaw Stock Exchange & Polska \\
\hline 12 & BIST All Shares & Borsa Istanbul & Turcja \\
\hline 13 & Swiss All Share Cumulative Dividend & SIX Swiss Exchange & Szwajcaria \\
\hline
\end{tabular}

Źródło: opracowanie własne.

Testy normalności rozkładów przeprowadzono dla logarytmicznych stóp zwrotu o interwałach 1, 2, 3 i 4-dniowym, dla każdego roku okresu badawczego 2005-2018 z osobna. Testy przeprowadzono również dla dwuletnich podokresów, a to w celu sprawdzenia czy wyniki testów przeprowadzonych dla dłuższych podokresów pozwolą na wysunięcie podobnych wniosków. Zastosowane interwały nie pokrywają się z praktyką stosowaną w analizie technicznej, gdzie najczęściej analizuje się interwały 1, 5, 10 czy 20-dniowe. Niemniej jednak w badaniach nad efektywnością informacyjną rynków największą uwagę skupia się na interwałach najmniejszych. Biorąc to pod uwagę, interwały najczęściej wykorzystywane w analizie technicznej wydają się być zbyt duże dla celów niniejszego badania.

Nawiązując do postawionej hipotezy badawczej, mówiącej, że globalny kryzys finansowy 2008 negatywnie wpłynął na efektywność informacyjną europejskich rynków akcji, co przejawiło się w niższym odsetku rynków efektywnych w okresie kryzysu w porównaniu z pozostałymi okresami, oczekiwane jest zaobserwowanie spadku liczby rynków efektywnych w latach ściśle związanych z kryzysem, tj. w latach 2007-2008. Większość z przytoczonych w części drugiej niniejszego artykułu badań swoją metodykę oparło na porównaniu wyników testów statystycznych z trzech z góry zdefiniowanych okresów, tj. okresu przedkryzysowego, kryzysowego i pokryzysowego. Z uwagi na trudności w zde- 
finiowaniu dokładnego początku i końca kryzysu zdecydowano się na przeprowadzenie testów dla poszczególnych lat oraz dwuletnich podokresów.

\section{Analiza wyników}

Tabela 2 przedstawia średni odsetek przypadków, w których stopy zwrotu miały rozkład normalny (nie było podstaw do odrzucenia hipotezy zerowej w teście normalności rozkładu). Średni odsetek przypadków został obliczony na podstawie wyników otrzymanych dla 13 badanych indeksów i został zaprezentowany dla każdego przeprowadzonego testu, interwału stóp zwrotu oraz dla poszczególnych lat. Ponadto ostatni wiersz tabeli przedstawia średnie wyniki dla całego okresu badawczego 2005-2018, a 4 ostatnie kolumny prezentują uśrednione wyniki dla wszystkich przeprowadzonych testów. Kolumny te stanowiły również podstawę do przygotowania rysunku 1, na którym każda z krzywych odnosi się do jednego z 4 interwałów stóp zwrotu.

Ta b e l a 2. Średni odsetek przypadków, w których stopy zwrotu miały rozkład normalny

\begin{tabular}{|c|c|c|c|c|c|c|c|c|c|c|c|c|c|c|c|c|}
\hline Test & \multicolumn{4}{|c|}{ Lilliefors } & \multicolumn{4}{|c|}{ Shapiro-Wilk } & \multicolumn{4}{|c|}{ D'Agostino-Pearson } & \multicolumn{4}{|c|}{ Wszystkie testy } \\
\hline Okres/interwał & 1 & 2 & 3 & 4 & 1 & 2 & 3 & 4 & 1 & 2 & 3 & 4 & 1 & 2 & 3 & 4 \\
\hline 2005 & 31 & 69 & 31 & 54 & 8 & 38 & 8 & 15 & 0 & 46 & 23 & 15 & 13 & 51 & 21 & 28 \\
\hline 2006 & 0 & 23 & 31 & 46 & 0 & 31 & 8 & 23 & 0 & 15 & 15 & 15 & 0 & 23 & 18 & 28 \\
\hline 2007 & 23 & 54 & 54 & 77 & 0 & 38 & 46 & 62 & 0 & 31 & 46 & 69 & 8 & 41 & 49 & 69 \\
\hline 2008 & 0 & 38 & 38 & 62 & 0 & 15 & 31 & 31 & 0 & 23 & 38 & 23 & 0 & 26 & 36 & 38 \\
\hline 2009 & 77 & 85 & 92 & 92 & 54 & 77 & 69 & 85 & 46 & 85 & 69 & 85 & 59 & 82 & 77 & 87 \\
\hline 2010 & 0 & 31 & 62 & 62 & 0 & 15 & 46 & 31 & 0 & 15 & 54 & 31 & 0 & 21 & 54 & 41 \\
\hline 2011 & 15 & 62 & 54 & 69 & 0 & 8 & 38 & 46 & 0 & 31 & 31 & 38 & 5 & 33 & 41 & 51 \\
\hline 2012 & 69 & 85 & 77 & 92 & 54 & 85 & 85 & 92 & 69 & 85 & 85 & 92 & 64 & 85 & 82 & 92 \\
\hline 2013 & 31 & 54 & 62 & 85 & 23 & 31 & 38 & 54 & 23 & 38 & 31 & 54 & 26 & 41 & 44 & 64 \\
\hline 2014 & 46 & 77 & 92 & 92 & 31 & 85 & 85 & 77 & 31 & 92 & 92 & 92 & 36 & 85 & 90 & 87 \\
\hline 2015 & 46 & 77 & 77 & 85 & 15 & 77 & 77 & 62 & 8 & 46 & 77 & 62 & 23 & 67 & 77 & 69 \\
\hline 2016 & 0 & 15 & 62 & 77 & 0 & 15 & 54 & 69 & 0 & 15 & 54 & 69 & 0 & 15 & 56 & 72 \\
\hline 2017 & 77 & 77 & 77 & 92 & 31 & 62 & 46 & 92 & 38 & 62 & 54 & 85 & 49 & 67 & 59 & 90 \\
\hline 2018 & 46 & 69 & 62 & 54 & 38 & 38 & 38 & 54 & 23 & 54 & 62 & 69 & 36 & 54 & 54 & 59 \\
\hline Razem & 33 & 58 & 62 & 74 & 18 & 44 & 48 & 57 & 17 & 46 & 52 & 57 & 23 & 49 & 54 & 63 \\
\hline
\end{tabular}

Źródło: opracowanie własne.

Nawiązując do postawionej hipotezy badawczej oczekiwane jest zaobserwowanie spadku odsetka rynków efektywnych w latach ściśle związanych z kryzy- 
sem, tj. w latach 2007-2008. Jak widać na rysunku 1, pierwszy spadek odsetka rozkładów normalnych nastąpił w roku 2006. W przeciwieństwie do oczekiwań, w przypadku wszystkich 4 interwałów stóp zwrotu, w roku 2007 odsetek rozkładów normalnych wzrósł by ponownie spaść w roku 2008, jednak w większości przypadków nie niżej niż w roku 2006.

R y s u n e k 1. Średni odsetek przypadków, w których stopy zwrotu miały rozkład normalny biorąc pod uwagę wszystkie przeprowadzone testy

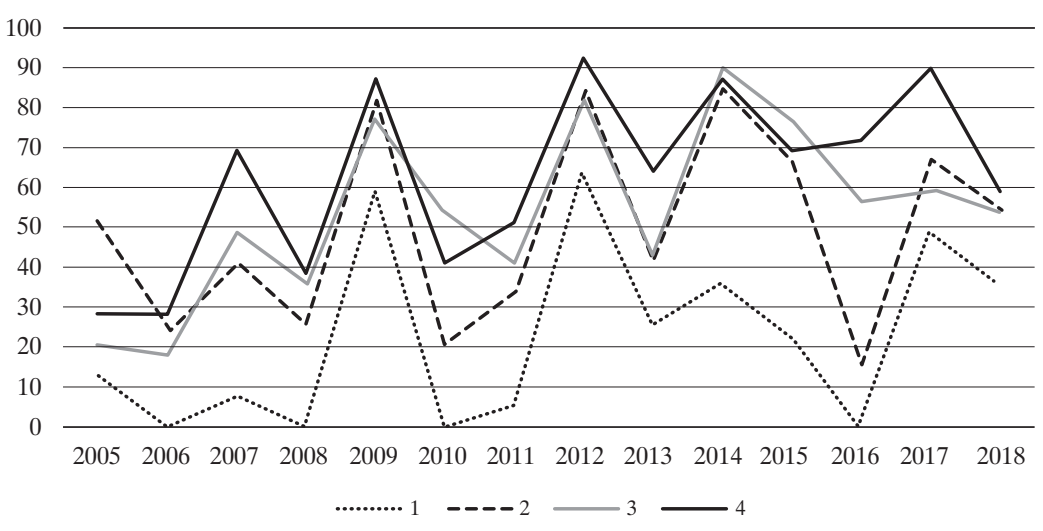

Źródło: opracowanie własne.

Rok 2009 okazał się być z jednym z największych odsetków rozkładów normalnych w przypadku wszystkich interwałów stóp zwrotu. Co więcej w przeciwieństwie do oczekiwań, w następnych latach można było zauważyć okresy ze znacznie obniżonym odsetkiem rozkładów normalnych. Dobrym przykładem takiego zjawiska są lata 2010 i 2016, szczególnie w przypadku interwałów 1 i 2-dniowych. Warto dodać, że widoczny trend wzrostowy krzywych dla interwałów 3 i 4-dniowych wskazuje na rosnący w czasie odsetek rynków efektywnych.

Tabela 3, podobnie jak tabela 2, przedstawia średni odsetek przypadków, w których stopy zwrotu miały rozkład normalny. Systematyka prezentowanych danych w obu tabelach jest taka sama. Niemniej jednak tabela 3 przedstawia dane dla okresów dwuletnich. Na podstawie 4 ostatnich kolumn tabeli 3 przygotowano rysunek 2 prezentujący średni odsetek przypadków, w których stopy zwrotu miały rozkład normalny, biorąc pod uwagę wszystkie przeprowadzone testy. 
Ta b e l a 3. Średni odsetek przypadków, w których stopy zwrotu miały rozkład normalny

\begin{tabular}{|l|r|r|r|r|r|r|r|r|r|r|r|r|r|r|r|r|}
\hline \multicolumn{1}{|c|}{ Test } & \multicolumn{4}{|c|}{ Lilliefors } & \multicolumn{4}{|c|}{ Shapiro-Wilk } & \multicolumn{4}{|c|}{ D'Agostino-Pearson } & \multicolumn{3}{c|}{ Wszystkie testy } \\
\hline Okres/interwa1 & 1 & 2 & 3 & 4 & 1 & 2 & 3 & 4 & 1 & 2 & 3 & 4 & 1 & 2 & 3 & 4 \\
\hline $2005-2006$ & 0 & 8 & 8 & 23 & 0 & 0 & 0 & 8 & 0 & 0 & 0 & 0 & 0 & 3 & 3 & 10 \\
\hline $2007-2008$ & 0 & 8 & 8 & 8 & 0 & 0 & 8 & 0 & 0 & 0 & 8 & 8 & 0 & 3 & 8 & 5 \\
\hline $2009-2010$ & 0 & 23 & 46 & 62 & 0 & 15 & 31 & 54 & 0 & 31 & 23 & 46 & 0 & 23 & 33 & 54 \\
\hline $2011-2012$ & 0 & 23 & 15 & 69 & 0 & 0 & 0 & 23 & 0 & 0 & 8 & 23 & 0 & 8 & 8 & 38 \\
\hline $2013-2014$ & 8 & 38 & 38 & 77 & 0 & 23 & 23 & 54 & 8 & 23 & 15 & 46 & 5 & 28 & 26 & 59 \\
\hline $2015-2016$ & 0 & 31 & 62 & 54 & 0 & 8 & 54 & 46 & 0 & 0 & 54 & 38 & 0 & 13 & 56 & 46 \\
\hline $2017-2018$ & 31 & 31 & 38 & 54 & 8 & 15 & 23 & 38 & 8 & 15 & 31 & 38 & 15 & 21 & 31 & 44 \\
\hline Razem & 5 & 23 & 31 & 49 & 1 & 9 & 20 & 32 & 2 & 10 & 20 & 29 & 3 & 14 & 23 & 37 \\
\hline
\end{tabular}

Źródło: opracowanie własne.

Szczególnie w przypadku interwałów 2, 3 i 4-dniowych dwa pierwsze, dwuletnie podokresy były okresami charakteryzującymi się najniższym odsetkiem rynków efektywnych. W kolejnych podokresach krzywe wspomnianych interwalów cechują się trendem wzrostowym. Pomimo okresowych spadków odsetka rynków efektywnych ich poziom nie spadł poniżej wartości z dwóch pierwszych podokresów. Jedynie w przypadku interwału 4-dniowego doszło do spadku odsetka rynków efektywnych z pierwszego na drugi podokres. Trzeci z kolei dwuletni podokres, tj. 2009-2010, charakteryzuje się jednym z największych odsetków rozkładów normalnych w przypadku niemalże wszystkich interwałów stóp zwrotu. Analiza danych zarówno dla okresów rocznych, jak i dwuletnich pozwala na wysunięcie podobnych wniosków.

R y s u n e k 2. Średni odsetek przypadków, w których stopy zwrotu miały rozkład normalny, biorąc pod uwage wszystkie przeprowadzone testy

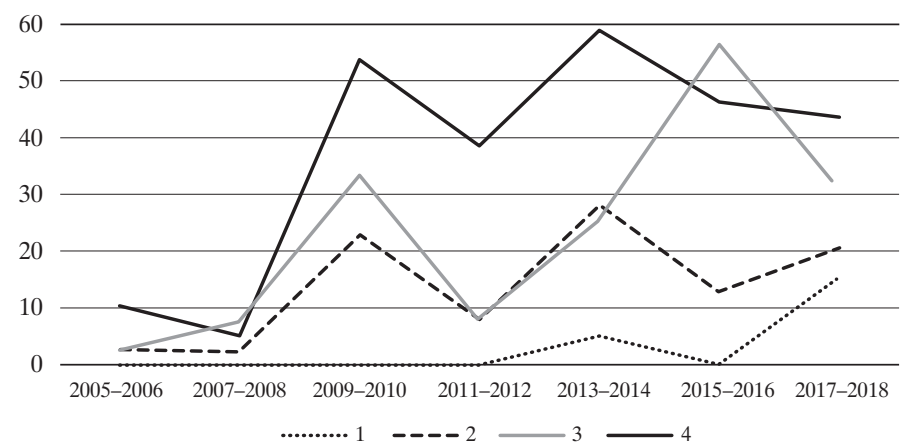

Źródło: opracowanie własne. 
Tabela 4 przedstawia średni odsetek przypadków, w których stopy zwrotu miały rozkład normalny, w podziale na poszczególne indeksy i lata, biorąc pod uwagę wszystkie przeprowadzone testy oraz interwały stóp zwrotu. Numeryczne nagłówki kolumn tabeli odnoszą się do liczb porządkowych poszczególnych indeksów przedstawionych w tabeli 1 . Ostatnia kolumna przedstawia średnie wyniki dla wszystkich indeksów. Wybrane dane pochodzące z tabeli 4 zostały zaprezentowane na rysunku 3, prezentującym krzywe odnoszące się do indeksów z minimalnym (OMX COPENHAGEN_PI oznaczony jako 7) oraz maksymalnym (OMX HELSINKI_PI oznaczony jako 8) odsetkiem przypadków, w których rynki były efektywne, biorąc pod uwagę wszystkie okresy, przeprowadzone testy i interwały stóp zwrotu. Dodatkowo rysunek 3 przedstawia wyniki dla wszystkich indeksów, pochodzące z ostatniej kolumny tabeli 4.

Celem prezentacji danych na poziomie poszczególnych indeksów było porównanie ich z danymi przeciętnymi biorącymi pod uwagę wszystkie indeksy oraz sprawdzenie czy dane przeciętne dla wszystkich indeksów, dotychczas zaprezentowane w artykule, mogą być uznane za reprezentatywne. Krzywe zaprezentowane na rysunku 3, pomimo różnych wartości średnich, cechują się podobnym sposobem kształtowania się.

Ta b e l a 4. Średni odsetek przypadków, w których stopy zwrotu miały rozkład normalny, w podziale na poszczególne indeksy i lata, biorąc pod uwagę wszystkie przeprowadzone testy oraz interwały stóp zwrotu

\begin{tabular}{|l|r|r|r|r|r|r|r|r|r|r|r|r|r|c|}
\hline Okres/interwal & $\mathbf{1}$ & $\mathbf{2}$ & $\mathbf{3}$ & $\mathbf{4}$ & $\mathbf{5}$ & $\mathbf{6}$ & $\mathbf{7}$ & $\mathbf{8}$ & $\mathbf{9}$ & $\mathbf{1 0}$ & $\mathbf{1 1}$ & $\mathbf{1 2}$ & $\mathbf{1 3}$ & $\begin{array}{c}\text { Wszystkie } \\
\text { indeksy }\end{array}$ \\
\hline 2005 & 25 & 58 & 33 & 58 & 17 & 0 & 0 & 33 & 8 & 0 & 33 & 25 & 75 & 28 \\
\hline 2006 & 33 & 0 & 25 & 0 & 8 & 8 & 8 & 33 & 0 & 0 & 42 & 25 & 42 & 17 \\
\hline 2007 & 42 & 58 & 50 & 8 & 58 & 42 & 17 & 67 & 42 & 25 & 33 & 58 & 42 & 42 \\
\hline 2008 & 8 & 0 & 8 & 0 & 25 & 8 & 8 & 50 & 33 & 25 & 75 & 58 & 25 & 25 \\
\hline 2009 & 58 & 83 & 67 & 100 & 83 & 50 & 67 & 75 & 75 & 100 & 75 & 83 & 75 & 76 \\
\hline 2010 & 33 & 33 & 33 & 8 & 17 & 25 & 8 & 67 & 58 & 33 & 17 & 33 & 8 & 29 \\
\hline 2011 & 33 & 25 & 42 & 83 & 58 & 0 & 25 & 50 & 33 & 33 & 0 & 25 & 17 & 33 \\
\hline 2012 & 100 & 67 & 75 & 33 & 83 & 100 & 75 & 92 & 75 & 83 & 83 & 100 & 83 & 81 \\
\hline 2013 & 58 & 33 & 8 & 33 & 83 & 83 & 50 & 50 & 42 & 0 & 33 & 50 & 42 & 44 \\
\hline 2014 & 75 & 67 & 75 & 33 & 100 & 67 & 58 & 100 & 75 & 92 & 58 & 100 & 67 & 74 \\
\hline 2015 & 75 & 67 & 75 & 75 & 67 & 58 & 75 & 42 & 33 & 75 & 33 & 83 & 8 & 59 \\
\hline 2016 & 42 & 33 & 25 & 17 & 25 & 25 & 17 & 67 & 50 & 25 & 67 & 25 & 50 & 36 \\
\hline 2017 & 100 & 50 & 33 & 33 & 75 & 58 & 58 & 75 & 83 & 58 & 67 & 83 & 83 & 66 \\
\hline 2018 & 33 & 50 & 17 & 50 & 67 & 33 & 42 & 83 & 58 & 50 & 100 & 67 & 8 & 51 \\
\hline Razem & 51 & 45 & 40 & 38 & 55 & 40 & 36 & 63 & 48 & 43 & 51 & 58 & 45 & 47 \\
\hline
\end{tabular}

Źródło: opracowanie własne. 
Wszystkie krzywe charakteryzują się trendami wzrostowymi. Analiza danych dla poszczególnych indeksów pozwala stwierdzić, że sposób kształtowania się danych poszczególnych indeksów na przestrzeni kolejnych okresów jest w większości przypadków zbliżony do zmian danych przeciętnych biorących pod uwagę wszystkie indeksy.

R y s u n e k 3. Średni odsetek przypadków, w których stopy zwrotu miały rozkład normalny dla indeksów z minimalnym (OMX COPENHAGEN_PI) oraz maksymalnym (OMX HELSINKI_PI) odsetkiem przypadków, w których rynki były efektywne, biorąc pod uwagę wszystkie okresy, przeprowadzone testy $i$ interwały stóp zwrotu

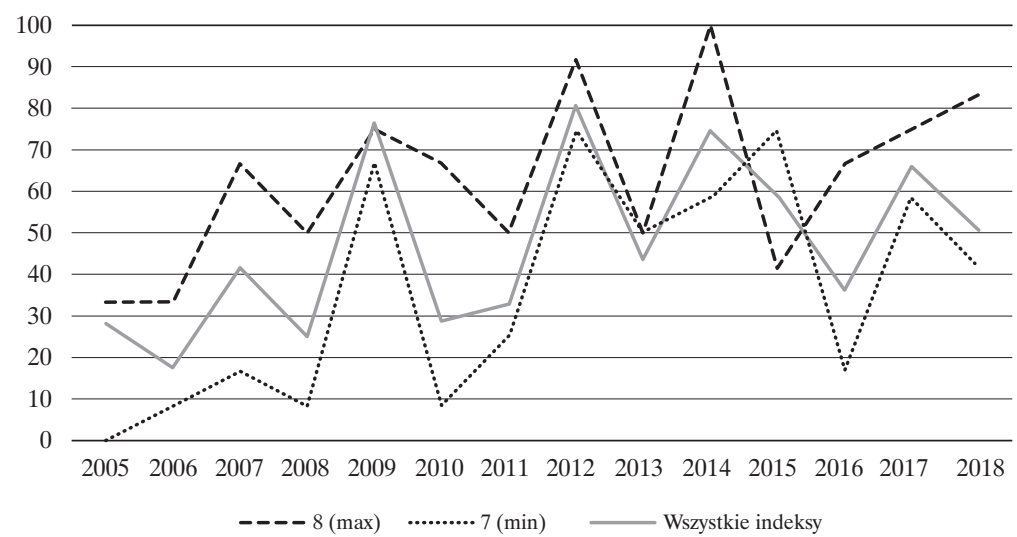

Źródło: opracowanie własne.

Tabela 5, podobnie jak tabela 4, przedstawia średni odsetek przypadków, w których stopy zwrotu miały rozkład normalny, w podziale na poszczególne indeksy, biorąc pod uwagę wszystkie przeprowadzone testy oraz interwały stóp zwrotu. Jednak w przeciwieństwie do tabeli 4 , tabela 5 prezentuje dane dla okresów dwuletnich. 
Ta b e la 5. Średni odsetek przypadków, w których stopy zwrotu miały rozkład normalny, w podziale na poszczególne indeksy i dwuletnie podokresy, biorąc pod uwagę wszystkie przeprowadzone testy oraz interwały stóp zwrotu

\begin{tabular}{|l|r|r|r|r|r|r|r|r|r|r|r|r|r|c|}
\hline Okres/interwaI & $\mathbf{1}$ & $\mathbf{2}$ & $\mathbf{3}$ & $\mathbf{4}$ & $\mathbf{5}$ & $\mathbf{6}$ & $\mathbf{7}$ & $\mathbf{8}$ & $\mathbf{9}$ & $\mathbf{1 0}$ & $\mathbf{1 1}$ & $\mathbf{1 2}$ & $\mathbf{1 3}$ & $\begin{array}{c}\text { Wszystkie } \\
\text { indeksy }\end{array}$ \\
\hline $2005-2006$ & 8 & 0 & 0 & 8 & 0 & 0 & 0 & 17 & 0 & 0 & 0 & 8 & 8 & 4 \\
\hline $2007-2008$ & 0 & 0 & 0 & 0 & 0 & 0 & 0 & 25 & 8 & 0 & 0 & 17 & 0 & 4 \\
\hline $2009-2010$ & 33 & 42 & 42 & 8 & 8 & 8 & 17 & 33 & 33 & 67 & 0 & 25 & 42 & 28 \\
\hline $2011-2012$ & 8 & 8 & 17 & 33 & 25 & 8 & 0 & 25 & 25 & 0 & 0 & 17 & 8 & 13 \\
\hline $2013-2014$ & 17 & 25 & 17 & 17 & 58 & 33 & 33 & 67 & 25 & 0 & 17 & 42 & 33 & 29 \\
\hline $2015-2016$ & 42 & 33 & 17 & 42 & 8 & 0 & 33 & 42 & 42 & 33 & 25 & 50 & 8 & 29 \\
\hline $2017-2018$ & 8 & 25 & 0 & 33 & 67 & 33 & 8 & 42 & 33 & 0 & 100 & 8 & 0 & 28 \\
\hline Razem & 17 & 19 & 13 & 20 & 24 & 12 & 13 & 36 & 24 & 14 & 20 & 24 & 14 & 19 \\
\hline
\end{tabular}

Źródło: opracowanie własne.

Ry s u n e k 4. Średni odsetek przypadków, w których stopy zwrotu miały rozkład normalny dla indeksów z minimalnym (PX-GLOB) oraz maksymalnym

(OMX HELSINKI_PI) odsetkiem przypadków, w których rynki były efektywne, biorąc pod uwagę wszystkie okresy, przeprowadzone testy i interwały stóp zwrotu

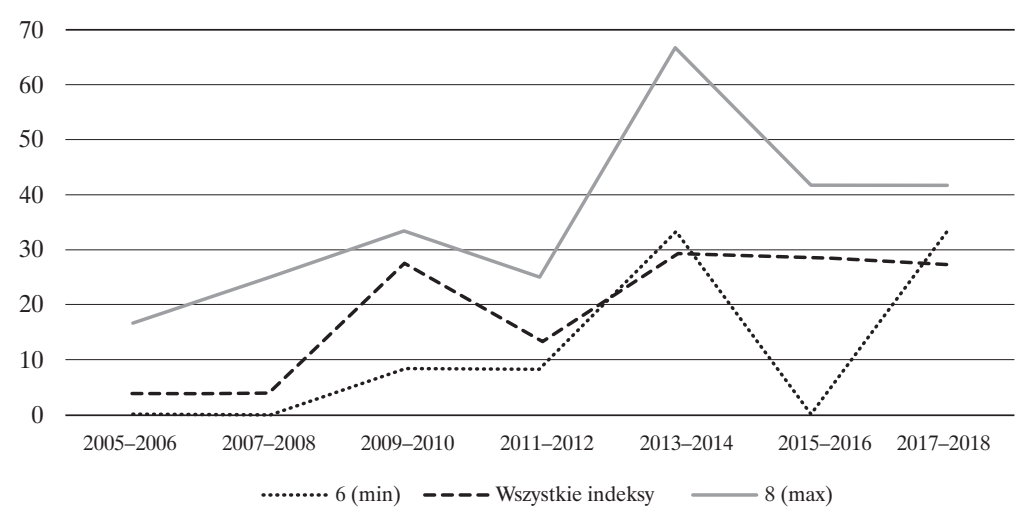

Źródło: opracowanie własne.

Wybrane dane pochodzące $\mathrm{z}$ tabeli 5 zostały zaprezentowane na rysunku 4 przedstawiającym krzywe odnoszące się do indeksów z minimalnym (PX-GLOB oznaczony jako 6) oraz maksymalnym (OMX HELSINKI_PI oznaczony jako 8) odsetkami przypadków, w których rynki były efektywne, biorąc pod uwagę wszystkie okresy, przeprowadzone testy i interwały stóp zwrotu. Dodatkowo rysunek 4 przedstawia wyniki dla wszystkich indeksów pochodzą- 
cych z ostatniej kolumny tabeli 5. Analiza danych dla dwuletnich podokresów pozwala stwierdzić, że, podobnie jak w przypadku danych dla poszczególnych lat, sposób kształtowania się danych poszczególnych indeksów na przestrzeni kolejnych dwuletnich podokresów jest w większości przypadków zbliżony do zmian danych przeciętnych biorących pod uwagę wszystkie indeksy.

\section{Wnioski}

Nawiązując do postawionej hipotezy badawczej, mówiącej, że globalny kryzys finansowy 2008 negatywnie wpłynął na efektywność informacyjną europejskich rynków akcji, co przejawiło się w niższym odsetku rynków efektywnych w okresie kryzysu w porównaniu z pozostałymi okresami, oczekiwane było zaobserwowanie spadku liczby rynków efektywnych w latach ściśle związanych z kryzysem, tj. w latach 2007-2008. Wyniki przeprowadzonego badania nie pozwalają na jednoznaczne stwierdzenie, że globalnemu kryzysowi finansowemu 2008 towarzyszył relatywnie niższy odsetek rynków efektywnych. Pomimo że w okresie ściśle związanym z kryzysem liczba rynków efektywnych była niska, to w kolejnych okresach odsetek rynków efektywnych zbliżał się do równie niskiego poziomu. Kolejnym argumentem przeciw przyjętej hipotezie badawczej jest gwałtowny wzrost odsetka rynków efektywnych w roku 2009, tj. w roku następującym po eskalacji kryzysu. Nawiązując do wyników badania, brakuje podstaw by z pewnością stwierdzić (jak Kian-Ping, Brooks i Kim, 2007), że w czasie kryzysu priorytetem powinny być działania regulacyjne mające na celu uspokojenie rynku czy przywrócenie zaufania inwestorów.

Badanie stanowiło odpowiedź na niejednoznaczne wyniki wcześniejszych badań poruszających tematykę wpływu globalnego kryzysu finansowego 2008 na efektywność informacyjną w formie słabej europejskich rynków akcji. Co więcej motywacją do przeprowadzenia badania było zastosowanie unikalnych założeń, takich jak wykorzystanie jedynie szerokich indeksów giełdowych uwzględniających wszystkie akcje notowane na danej giełdzie czy przeprowadzenie rygorystycznych testów normalności rozkładów stóp zwrotu dla 4 różnych, lecz krótkich interwałów 1, 2, 3 i 4-dniowych, w rocznych i dwuletnich okresach. Zastosowanie wspomnianych, unikalnych założeń, które szerzej zostały opisane w części trzeciej stanowi o nowym ujęciu poruszanej problematyki. Największą przeszkodą z jaką spotkano się podczas przeprowadzenia badania była ograniczona długość szeregów czasowych szerokich indeksów akcji w okresach przedkryzysowych oraz ograniczona wielkość próby. Przeprowadzenie analogicznego badania dla innych typów indeksów niż szerokie indeksy uwzgledniające wszystkie akcje notowane na danym rynku doprowa- 
dziłoby do zwiększenia próby i wydłużenia analizowanych szeregów czasowych.

\section{Bibliografia}

Anagnostidis, P., Varsakelis, C. i Emmanouilides, C.J. (2016). Has the 2008 financial crisis affected stock market efficiency? The case of Eurozone. Physica A: Statistical Mechanics and its Applications, 2016(447), 116-128. htpps://doi.org/10.1016/j.physa.2015.12.017.

Borowski, K. (2017). Rozkład normalny stóp zwrotu z akcji wchodzących w skład następujących indeksów giełdowych: WIG20, MWIG40 i SWIG80. Metody ilościowe w badaniach ekonomicznych, XVIII/4, 541-560. htpps://doi.org/10.22630/MIBE.2017.18.4.50.

Cheong, C.W., Nor, A.H.S.M. i Isa, Z. (2007). Asymmetry and long-memory volatility: Some empirical evidence using GARCH. Physica A: Statistical and Theoretical Physics, 373, 651-664. htpps://doi.org/10.1016/j.physa.2006.05.050.

Czekaj, J. (2014). Efektywność giełdowego rynku akcji w Polsce z perspektywy dwudziestolecia. Warszawa: PWE.

Fama, E.F. (1970). Efficient Capital Markets: A Review of Theory and Empirical Work. Journal of Finance, 25(2), 383-417. htpps://doi.org/10.2307/2325486.

Hoque, H.A.A.B., Kim, J.H. i Pyun, C.S. (2007). A comparison of variance ratio tests of random walk: A case of Asian emerging stock markets. International Review of Economics and Finance, 16(4), 488-502. htpps://doi.org/10.1016/j.iref.2006.01.001.

Horta, P., Lagoa, S. i Martins, L. (2014). The impact of the 2008 and 2010 financial crises on the Hurst exponents of international stock markets: Implications for efficiency and contagion. International Review of Financial Analysis, 2014(35), 140-153. htpps://doi. org/10.1016/j.irfa.2014.08.002.

Jensen, M.C. (1978). Some Anomalous Evidence Regarding Market Efficiency. Journal of Financial Economics, 6(2-3), 95-101. htpps://doi.org/10.1016/0304-405X(78)90025-9.

Katris, C. i Daskalaki, S. (2013). Effect of economic crisis in efficiency and predictability of Greek and German stock indices. Proceedings of the 3rd International Conference: Quantitative and Qualitative Methodologies in the Economic \& Administrative Sciences, QMEAS 2013, 224-230.

Kian-Ping, L., Brooks, R.D. i Kim, J.H. (2007). Financial crisis and stock market efficiency: Empirical evidence from Asian countries. International Review of Financial Analysis, 2008(17), 571-591. htpps://doi.org/10.1016/j.irfa.2007.03.001.

Kilon, J. i Jamróz, P. (2015). Informational (in)efficiency of the Polish Stock Exchange. Procedia - Social and Behavioral Sciences, 213, 390-396. htpps://doi.org/10.1016/j. sbspro.2015.11.556.

Kim, J.H. i Shamsuddin, A. (2008). Are Asian stock markets efficient? Evidence from new multiple variance ratio tests. Journal of Empirical Finance, 15(3), 518-532. htpps://doi. org/10.1016/j.jempfin.2007.07.001.

Loser, C.M. (2009). Global Financial Turmoil and Emerging Market Economies: Major Contagion and a Shocking Loss of Wealth? Global Journal of Emerging Market Economies, 2009(1), 137-158. htpps://doi.org/10.1177/097491010900100203.

Mensi, W., Tiwari, A.K. i Yoon, S.M. (2017). Global financial crisis and weak-form efficiency of Islamic sectoral stock markets: An MF-DFA analysis. Physica A: Statistical Mechanics and its Applications, 2017(471), 135-146. htpps://doi.org/10.1016/j.physa.2016.12.034. 
Mensi, W., Tiwari, A.K. i Al-Yahyaee, K.H. (2019). An analysis of the weak form efficiency, multifractality and long memory of global, regional and European stock markets. The Quarterly Review of Economics and Finance, 72(C), 168-177. htpps://doi.org/10.1016/j. qref.2018.12.001.

Sensoy, A. i Tabak, B.M. (2015). Time-varying long term memory in the European Union stock markets. Physica A: Statistical Mechanics and its Applications, 2015(436), 147-158. htpps://doi.org/10.1016/j.physa.2015.05.034.

Singh, P., Deepak, C.A. i Kumar, A. (2015). Revisiting Weak Form Efficiency of Major Equity Markets in light of Global Financial Crisis: A Panel Data Approach. Asia-Pacific Finance and Accounting Review, 3(1), 17-44.

Smith, G. (2012). The changing and relative efficiency of European emerging stock markets, The European Journal of Finance, 18(8), 689-708. htpps://doi.org/10.1080/135184 7X.2011.628682. 



\title{
Rozdział 4
}

\author{
PRZEMYSŁAW RYŚ*, ROBERT ŚLEPACZUK**
}

\section{Implementacja i efektywność metod uczenia maszynowego w optymalizacji algorytmicznych strategii inwestycyjnych ${ }^{1}$}

Głównym celem artykułu jest sformułowanie i przeanalizowanie metod uczenia maszynowego (machine learning, ML), adekwatnych do specyfiki zagadnienia optymalizacji parametrów strategii inwestycyjnych. Najważniejsze wyzwania wynikają z wrażliwości wyników strategii na małe zmiany parametrów oraz występowania licznych, lokalnych ekstremów, nieregularnie rozłożonych w przestrzeni rozwiązań. Metody ML, wykorzystane w artykule, zostały zaprojektowane w taki sposób, aby istotnie skrócić czas obliczeń, bez dużej utraty efektywności strategii. Efektywność analizowanych metod została porównana na przykładzie trzech par aktywów, jednakże z uwagi na podobieństwo wniosków, w pracy zostały przedstawione jedynie wyniki dla kontraktów na indeksy akcyjne (indeks S\&P500 i DAX) dla systemu przecięcia średnich kroczących. Metody ML były wykonywane dla dziennych danych w okresie od 1998 do 2017 roku. Główna hipoteza badawcza pracy mówi, że testowane metody ML wybierają strategie ze zbliżoną wartością do maksymalnego kryterium optymalizacyjnego, ale wykonują to działanie w istotnie krótszym czasie niż standardowe podejście przeszukujące całą siatkę parametrów.

Słowa kluczowe: handel algorytmiczny, strategie inwestycyjne, uczenie maszynowe, optymalizacja.

* Przemysław Ryś - Quantitative Finance Research Group, Faculty of Economic Sciences, University of Warsaw and Labyrinth HF project, ul. Długa 44/50, 00-241 Warszawa, Polska.

** dr Robert Ślepaczuk - Quantitative Finance Research Group, Faculty of Economic Sciences, University of Warsaw and Labyrinth HF project, ul. Długa 44/50, 00-241 Warszawa, Polska; https://orcid.org/0000-0001-5227-2014.

1 Poglądy i opinie przedstawione w publikacji nie odzwierciedlają stanowiska projektu Labyrinth HF, a jedynie stanowiska autorów (The views presented in this text are those of the authors and do not necessarily represent those of Circus Consulting Group nor LHF project). 


\section{Implementation and Efficiency of Machine Learning Methods in Optimization of Algorithmic Investment Strategies}

The main purpose of this article is to formulate and analyze machine learning (ML) methods that are relevant to the specificity of the issue of optimizing investment strategy parameters. The main challenge is a sensitivity of the strategy results to small changes in parameters and numerous local extremes appearing in the space of solutions in an irregular way. The ML methods used in the article were designed in such a way as to significantly reduce the time of calculations, without any significant loss of strategy efficiency. The efficiency of the methods analyzed was compared on the example of three asset pairs, however, due to the similarity of applications, only the results for contracts for stock indexes (S\&P500 and DAX index) for the moving average crossover system are presented in the paper. ML methods were executed on daily data from 1998 to 2017. The main research hypothesis of the work says that the tested ML methods choose strategies with a value close to the maximum optimization criterion, but they perform this action in a significantly shorter time than the standard approach searching the entire parameter grid.

Keywords: algorithmic trading, investment strategies, machine learning, optimization.

JEL: C61, G11, G17

\section{Wprowadzenie}

W ostatnich latach byliśmy świadkami ogromnego wzrostu popularności i szybkiego rozwoju metod uczenia maszynowego (machine learning) oraz sztucznej inteligencji. Nowe klasy algorytmów zostały z powodzeniem zaaplikowane do wielu trudnych problemów z różnych dziedzin nauki, dzięki czemu powstało wiele udogodnień dla codziennego życia. Dlatego też, wykorzystanie podobnych metod, aby usprawnić proces optymalizacji strategii inwestycyjnej wydaje się być naturalnym wyborem.

Podstawowym celem tego badania było sformułowanie i przeanalizowanie metod ML, dopasowanych do specyfiki optymalizacji strategii inwestycyjnych. Najważniejszym problemem w tym zadaniu jest wrażliwość wyników strategii na małe zmiany parametrów oraz liczne ekstrema pojawiające się w nieregularny sposób w przestrzeni parametrów. Opracowane metody ML zostały zaprojektowane, aby istotnie skrócić czas obliczeń, bez zauważalnego spadku jakości strategii. Efektywność metod została porównana dla trzech par aktywów dla systemu przecięcia średnich kroczących. Rozważane algorytmy ML: Extended Hill Climbing (EHC), Grid Method (GM) i Metoda Ewolucji Różnicowej (Differential Evolution Method (DEM)), są oparte na dobrze znanych koncepcjach z zakresu uczenia maszynowego lub własnych pomysłach autorów zakładających wykorzystanie obserwacji poprzednich kroków w celu usprawnienia 
dalszego procesu optymalizacji. Wyniki metod zostały porównane z metodą wyszukiwania wyczerpującego (Exhaustive Search Method, ES), nazywaną także podejściem brute-force.

Główna hipoteza badawcza weryfikowana w pracy brzmiała następująco: Wyniki metod ML sa takie same lub nieznacznie gorsze od metody wyszukiwania wyczerpującego (ES), ale czas obliczeń jest istotnie niższy niż w przypadku metody ES, gdzie sprawdzamy petnq siatkę parametrów. Podstawowym zadaniem metod ML, przedstawionych w tym artykule, był wybór parametrów strategii maksymalizujących jej wyniki oceniane przez specjalnie zdefiniowane kryterium optymalizacyjne. W związku z powyższym, podstawowym celem pracy nie było znalezienie optymalnej strategii inwestycyjnej, ale porównanie efektywności działania różnych metod ML z metodą wyszukiwania wyczerpującego.

Metody zostały zastosowane i zweryfikowane na danych w okresie treningowym (in-sample), składającym się z 16 lat danych dziennych (1998-2013), a następnie ich wyniki zostały zweryfikowane w okresie walidacyjnym, składającym się z 4 kolejnych lat (2014-2017). Obliczenia zostały wykonane na trzech parach aktywów (na kontraktach futures na indeks SPX i DAX, na akcje AAPL i MSFT, na kontraktach towarowych na HGF i CBF). W ramach wyników badania przedstawiono rozkład kryterium optymalizacyjnego i czasu obliczeń dla 1000 powtórzeń wykonania testowanych metod, które następnie porównano z wynikami metody ES. Ze względu na ograniczoną objętość pracy oraz podobieństwo uzyskiwanych rezultatów przedstawiamy wyniki tylko dla pary indeksów SPX i DAX. Wyniki testowanych metod zostały sprawdzone zarówno na okresie in-sample, jak i out-of-sample, w celu sprawdzenia skłonności rozpatrywanych metod do przeoptymalizowania wyników strategii, co ze względu na ograniczoną objętość pracy nie będzie omawiane.

\section{Przegląd literatury}

Metody uczenia maszynowego były wykorzystywane w badaniach od dekad, nawet przed wprowadzeniem tego terminu w latach 50. XX wieku (Samuel, 1959). Niemniej jednak w ostatnich latach zaobserwowano zwiększone zainteresowanie tą dziedziną, ze względu na techniczną możliwość zastosowania sztucznej inteligencji w różnych dziedzinach nauki i życia. Zjawisko uczenia się z punktu widzenia obliczeniowego zostało omówione przez Valianta (1984). Powszechnie stosowane metody i algorytmy mające zastosowanie w problemach naukowych zostały omówione w Hastie i in. (2001) i Hastie i in. (2013).

Strategie algorytmiczne są szeroko stosowane na rynkach finansowych, ale większość z nich nie jest omawiana w artykułach, ze względu na ich zastrzeżo- 
ny charakter. Strategie oparte na wskaźnikach analizy technicznej, takich jak system przecięcia średnich kroczących uwzględniony w niniejszym artykule, są analizowane w Gunasekarage and Power (2001). Szerokie zastosowanie metod uczenia maszynowego w innych dziedzinach stało się niewątpliwą motywacją do próby wykorzystania ich do problemów inwestycyjnych, w tym do konstrukcji strategii algorytmicznych. Poza komercyjnym użyciem opublikowano również prace naukowe opisujące strategie z logiką opartą na uczeniu maszynowym, np. w pracy Sanković i in. (2015), grupa badaczy przedstawiła strategię opartą na analizie technicznej i Support Vector Machines (SVM). Badacze jednak w przeciwieństwie do naszego artykułu, wykorzystali metody uczenia maszynowego jako część systemu generującego sygnały transakcyjne, a nie jako część procesu optymalizacji systemu.

Shen i in. (2012) zaprezentowali model indeksów giełdowych, oparty na $S V M$ i przetestowali system transakcyjny na podstawie wygenerowanych prognoz. Podobne podejście przyjęto w Choundhry i Kumkum (2008), gdzie wprowadzono hybrydowy system uczenia maszynowego, łączący SVM z algorytmem genetycznym w celu prognozowania cen akcji.

Metoda ewolucji różnicowej, na której bazuje jedna z omawianych w tym artykule metod, została zaprojektowana przez Storna i Price'a (1997) i omówiona m.in. w Price i in. (2006). Metoda ta była stosowana do efektywnego rozwiązywania niewypukłych problemów z optymalizacją portfela (Ardia i in., 2010) oraz problemu minimalizacji CVAR dla dużego portfela (Ardia i in., 2011a).

\section{Metodologia}

Kryterium optymalizacyjne jest zdeterminowane przez statystyki linii equity, którą otrzymuje się, wyznaczając wartość strategii w każdym dniu okresu treningowego. Codzienne wyznaczanie sygnału kupna-sprzedaży oraz uwzględnienie rebalancingu i kosztów transakcyjnych wymaga sporej liczby obliczeń, które ze względu na wydajność wykonywane były przez moduł napisany w języku $\mathrm{C}++$. Pozostałe elementy systemu, w tym rozpatrywane metody zostały zaimplementowane w pakiecie R, ze względu na możliwości wektoryzacji i szeroką dostępność do dodatkowych funkcji.

\subsection{Podstawowe pojęcia}

Głównym problemem było znalezienie najlepszych parametrów strategii inwestycyjnej w klasie strategii, opartych na systemie przecięcia średnich kro- 
czących. Zachowanie każdej strategii zostało w pełni określone przez wektor parametrów z czterowymiarowej przestrzeni $\psi$, z których każdy odpowiada za długość okna dla innej średniej ruchomej ( 2 aktywa * 2 średnie). Dokładniej, każda strategia została sparametryzowana przez wektor $p=\left(p_{1}, p_{2}, p_{3}, p_{4}\right) \in \Psi$, tak że sygnały kupna/sprzedaży $U_{t}^{i}$ dla $i \in\{1,2\}$ zostały wyznaczone za pomocą następującego wzoru:

$$
U_{t}^{i}=\operatorname{sign}\left(M A_{1}^{i}\left(S^{i}\right)_{t-1}-M A_{2}^{i}\left(S^{i}\right)_{t-1}\right),
$$

gdzie: $M A_{j}^{i}\left(S^{i}\right)$ oznaczał prostą średnią ruchomą o długości $p_{2 i+j-2}$ dla szeregu cen $S i$, co oznacza, że $p_{1}$ i $p_{2}$ oznaczają długości średnich ruchomych używanych dla pierwszego instrumentu i analogicznie $p_{3}$ i $p_{4}$ odnoszą się do drugiego.

Kryterium optymalizacyjne zostało oparte na typowych statystykach efektywności stosowanych do oceny strategii inwestycyjnych złożonych w ramach zaproponowanego przez nas konceptu kryterium: zannualizowanej stopie zwrotu (ARC), zannualizowanym odchyleniu standardowym (ASD) i maksymalnym obsunięciu kapitału (MDD). Kryterium zostało określone za pomocą następującego wzoru:

$$
O C=\frac{A R C *|A R C|}{A S D * M D D}
$$

Konstrukcja kryterium optymalizacyjnego OC odzwierciedla preferencję do wybierania mniej rentownych strategii o niskim ryzyku, zamiast bardziej zyskownych, cechujących się znacznie większym ryzykiem. Ze względu na użycie MDD strategie o niższych zyskach i stabilnym wzroście były częściej wybierane niż te bardziej dochodowe, w których występowały okresy znacznych strat.

\subsection{Specyfika rozpatrywanego problemu}

Problem dopasowania strategii algorytmicznej do szeregów czasowych został sprowadzony do matematycznego zagadnienia optymalizacji kryterium $O C$ (funkcji nagrody) na zadanej przestrzeni parametrów (rozwiązań) $\psi$. Zarówno funkcja nagrody, jak i przestrzeń rozwiązań mają istotne własności, które powinny zostać uwzględnione przy konstrukcji metod uczenia maszynowego, tak aby zapewnić możliwie największą wydajność.

Pierwszym ograniczeniem w stosowaniu typowych metod jest dyskretność przestrzeni rozwiązań. Co więcej kryterium optymalizacyjne nie ma analitycznej formy, tylko jest wyznaczane w stosunkowo długotrwałym procesie, co uniemożliwia stosowanie metod gradientowych. Proces wyznaczania wartości 
kryterium optymalizacyjnego polega na przeprowadzeniu symulacji stosowania strategii na giełdzie w całym okresie testowym, uwzględniając odpowiednie koszty transakcyjne i inne elementy mechaniki giełdy. Trudność problemu związana jest więc w dużej mierze ze sporym kosztem czasowym ewaluacji rozwiązań, przy ich stosunkowo niewielkiej liczbie (niecałe 200000 kombinacji).

Wyniki strategii zwykle są bardzo wrażliwe nawet na niewielkie zmiany parametrów, co oznacza, że można spodziewać się wielu ekstremum lokalnych na całej przestrzeni oraz stosunkowo dużych różnic w osiąganych wynikach przez strategie odpowiadające bliskim punktom przestrzeni parametrów. Stanowi to kluczowe wyzwanie, które wymaga konstrukcji bardziej złożonych metod machine learningowych. Warto jednak zwrócić uwagę, że metody optymalizacji potrzebują pewnego poziomu stabilności, bo opierają się na założeniu, że optymalne rozwiązanie będzie otoczone rozwiązaniami o wyższym kryterium optymalizacyjnym niż w innych częściach przestrzeni. Ta właściwość jest bardzo pożądana przy konstrukcji strategii, ponieważ doprowadza do omijania mniej stabilnych rozwiązań, co redukuje ryzyko przeuczenia, zwiększając szanse na wybór strategii osiągającej dobre rezultaty w przyszłości.

Metody wprowadzone w tej pracy zostały zaprojektowane na bazie znanych algorytmów, w sposób umożliwiając wydajne rozwiązywanie rozpatrywanego problemu, który jest z różnych przyczyn niemożliwy do rozwiązania przez podstawowe algorytmy. Omawiane metody wykazują wprawdzie mniejszą tendencję do przeoptymalizowania strategii niż wyszukiwanie wyczerpujące, ale głównym celem ich konstrukcji było usprawnienie procesu wyboru parametrów. W związku z tym praca skupia się na ich efektywności czasowej, nie przedstawiając dodatkowych rozwiązań, ukierunkowanych na zmniejszanie ryzyka przeuczenia strategii.

\subsection{Metoda wyszukiwania wyczerpującego (The Exhaustive Search (ES))}

Strategie wybierane przez różne metody uczenia maszynowego są w dalszej części pracy analizowane i porównywane ze strategią optymalną, czyli osiągającą najwyższą możliwą wartość kryterium optymalizacyjnego w okresie treningowym. Znalezienie takiej strategii wymaga sprawdzenia wartości kryterium dla każdego zestawu parametrów z przestrzeni rozwiązań, czyli zastosowania metody wyszukiwania wyczerpującego. Metoda jest powszechnie stosowana ze względu na możliwość szybkiej implementacji oraz gwarancję znalezienia optymalnego rozwiązania. Niestety obliczenie wartości kryterium dla każdego z punktów przestrzeni parametrów wymaga bardzo długiego czasu, szczególnie dla dużych przestrzeni. Dlatego też głównym zadaniem rozwijanych metod 
uczenia maszynowego jest znaczące skrócenie czasu obliczeń, bez istotnego spadku jakości rozwiązań. Metody te wykorzystują w kolejnych krokach informacje nabyte w poprzednich, dostosowując swoje działanie w trakcie trwania. Różnica w czasie uzyskania podobnych wyników odzwierciedla znaczenie nabytych informacji dla wydajności dalszego wyszukiwania. Ze względu na intuicyjny charakter i szerokie zastosowanie metoda ES traktowana będzie jako punkt odniesienia dla testowanych metod.

\subsection{Metoda Extended Hill Climbing (EHC)}

Podstawowa metoda Hill Climbing (HC) to lokalna metoda wyszukiwania, oparta na bardzo intuicyjnym podejściu - poruszania się zawsze w taki sposób, który poprawia wartość kryterium optymalizacyjnego. Algorytm operuje na grafie złożonym z wierzchołków (punktów) z przypisanym kryterium optymalizacyjnym oraz krawędzi, które określają relację sąsiedztwa. Podstawowym algorytmem metody HC jest prosta pętla, rozpoczynająca się w określonym punkcie i wielokrotnie zmieniająca bieżący punkt na sąsiada o wyższej wartości kryterium optymalizacji, o ile taki występował. Klasyczna procedura HC sprawdza wszystkich sąsiadów i przechodzi do tego z największą wartością kryterium. Trafną paralelą dla tego algorytmu jest „próba znalezienia szczytu Mount Everest w gęstej mgle, podczas gdy cierpimy na amnezję" (Russell i Nowig, 2003). Metoda znajduje jedynie pewne maksimum lokalne, które może być zdecydowanie niższe od globalnego, co stanowi istotne ograniczenie w użyciu tej metody. Sąsiedzi są często definiowani jako punkty o określonej odległości pomiędzy sobą. W takim przypadku algorytm przechodzi przez przestrzeń parametrów za pomocą kroków o określonym rozmiarze. Metoda HC jest dobrze dostosowana do problemów z dużą regularnością, np. dla optymalizacji wypukłej, gdzie istnieje dokładnie jedno maksimum lokalne (Skiena, 2008). Nie ma powodu, aby zakładać, że rozpatrywany przez nas problem ma tę właściwość, dlatego wysiłek włożony w poprawę tej metody skupiał się na dostosowaniu tej metody do przestrzeni z wieloma lokalnymi ekstremami.

Metoda Extended Hill Climbing (EHC) składa się z niezależnych wywołań metody HC, nazywanych spacerami, które startują z losowych punktów. Rezultatem metody jest najlepszy wynik osiągnięty pośród nich. Każdy pojedynczy spacer polega na sprawdzeniu sąsiadów bieżącego punktu i przejściu do pierwszego z tych o wyższym kryterium. Jest to zasadniczo odmienne podejście od tradycyjnego, które pozwala na zmniejszenie czasu obliczeń, dzięki pominięciu obliczeń dla części sąsiadów. Kolejnym rozszerzeniem jest użycie kilku różnych struktur sąsiadów, z których każda składa się z punktów o określonej 
dla siebie odległości. Metoda przechodzi po przestrzeni rozwiązań, zaczynając od dużych kroków, co pozwala na szybkie pokonywanie dużych odległości, ale zmniejsza krok (rozpatruje nową strukturę sąsiedztwa), jeśli nie ma możliwości poprawy za pomocą kroku dotychczasowego rozmiaru. Spacer się kończy, gdy osiągnięty zostaje minimalny krok i żaden z sąsiadów nie ma wyższego kryterium od obecnego punktu. Założono, że kroki maleją wykładniczo, to znaczy są zdefiniowane jako $\left\{F,\left[\frac{F}{k}\right\rceil,\left[\frac{F}{k^{2}}\right], \ldots, 1\right\}$, gdzie $F$ jest początkowym krokiem, w tej pracy równym 5 oraz $k$ jest parametrem skali, w pracy równym 2. Dynamiczna wielkość kroku jest kluczowa, ponieważ dzięki niej metoda ma możliwość dojścia do każdego punktu z przestrzeni, a dodatkowo wybrana początkowa wielkość kroku ma mniejsze znaczenie niż w przypadku klasycznego algorytmu, co ułatwia jej stosowanie.

Liczba spacerów wymagana do osiągnięcia satysfakcjonujących wyników może być różna w zależności od szczęścia w losowaniu punktów startowych. Dlatego też wykonanie ustalonej z góry liczby doprowadza do niższej stabilności wyników, kiedy liczba okazuje się za mała lub zbyt długiego czasu, kiedy ta liczba jest zbyt duża. Rozwiązaniem tego problemu jest wprowadzony w metodzie mechanizm dynamicznego ustalania liczby spacerów, które wykorzystuje informacje o efektywności poprzednich. Metoda rozpoczyna nową, dwukrotnie większą pulę spacerów zawsze wtedy, gdy w poprzedniej puli udało się poprawić wynik, co wskazuje na dalszą możliwość poprawy. Ten mechanizm poprawia stabilność osiąganego kryterium optymalizacyjnego kosztem stabilności czasowej - przy braku szczęścia metoda może wymagać większej liczby spacerów, co wydłuża czas wykonania metody, ale zmniejsza szanse otrzymania przypadkiem dużo gorszego wyniku od osiąganego przeciętnie. W tej pracy przyjęto początkową liczbę spacerów równą 5.

\subsection{Metoda Siatki (Grid Method (GM))}

Druga metoda uczenia maszynowego, przygotowana na potrzeby tej pracy jest zaprojektowana do przeszukiwania ograniczonej przestrzeni dyskretnych parametrów o ustalonej odległości pomiędzy sobą, nazwanej kratą (siatką). Metoda składa się z prostych wyszukiwań wyczerpujących stosowanych do tworzonych dynamicznie nowych krat. Działanie algorytmu rozpoczyna się od przeszukania kraty o rozmiarze wyjściowej przestrzeni, ale dużych odległościach pomiędzy punktami (w tej pracy równej 5). Następnie przeszukiwane są kolejne kraty o coraz mniejszych odległościach pomiędzy punktami, scentrowane na najlepszym punkcie z poprzedniej, co w rezultacie prowadzi do otrzyma- 
nia krat o minimalnej odległości pomiędzy punktami. Z każdej kraty wybierany jest jeden najlepszy punkt, stanowiący środek kolejnej. Wyjątek stanowi pierwsza siatka, która początkuje niezależne procesy rozpoczynających się w kilku najlepszych punktach (w tej pracy przyjęto 6). Po przeszukaniu najmniejszych siatek zwracany jest najlepszy wynik, który zgodnie z konstrukcją metody ma najwyższe kryterium optymalizacyjne spośród sprawdzonych dotychczas punktów. Warto zaznaczyć, że metoda jest czysto deterministyczna, więc wybiera zawsze tę samą strategię, w bardzo zbliżonym i łatwym do oszacowania czasie. Metoda sprawdza jedynie punkty w stosunkowo niedużej odległości od najlepszych z początkowej kraty, ale ryzyko przeoczenia bardzo dobrych rozwiązań jest minimalizowane przez rozpatrywanie wielu punktów startowych. Wszystkie kraty mają tę samą liczbę punktów (tu 25) i kształt kwadratu. Opisywana metoda została w całości opracowana przez autorów tej pracy i nie stanowi rozszerzenia istniejącej metody. Nie mniej jednak, ze względu na stosunkowo prostą zasadę działania można spodziewać się występowania podobnych metod zaprojektowanych niezależnie.

\subsection{Metoda Ewolucji Różnicowej (Differential Evolution Method (DEM))}

Metoda Ewolucji Różnicowej inspirowana jest biologicznym zjawiskiem ewolucji. Algorytm ten naśladuje ewolucję, biorąc losową próbkę z przestrzeni rozwiązań (populację), dokonując w niej selekcji najlepszych zestawów parametrów, a następnie powielając je z losowo zaburzonymi cechami w nowej próbce (reprodukcja i mutacja). Opisane kroki są powtarzane dla kolejnych próbek (pokoleń), co pozwala na otrzymanie próbki złożonej z bardzo podobnych zestawów parametrów, determinujących strategie o wysokim kryterium optymalizacyjnym. Mechanizm losowych mutacji pozwala na eksplorację przestrzeni i znajdowanie nowych obiecujących rozwiązań, których cechy zostają powielane w kolejnych iteracjach. W metodzie tej występuje pewne podobieństwo do omawianej Metody Siatki - obie metody sprawdzają strategie z pewnej próbki i tworzą nowe, wykorzystując nabyte informacje o poprzednich. Zdolność do nauki i wykorzystania nabytej wiedzy jest typową cechą metod uczenia maszynowego. W pracy wykorzystano implementacje w języku R algorytmu JDEoptim z pakietu DEoptim w wersji 2.2-4 z domyślnymi parametrami (Mullen i in. 2016). Omawiana metoda była przystosowana do operowania na przestrzeniach ciągłych, ale została zaadaptowana do dyskretnej przestrzeni poprzez interpolację kryterium za pomocą zaokrąglenia. Wartość kryterium zwracana dla niecałkowitych parametrów jest wartością najbliższego punktu o całkowitych współrzędnych. 


\section{Opis danych oraz opis badania}

\subsection{Dane}

Opisane w pracy metody zostały przetestowane na trzech różnych parach instrumentów - kontraktach terminowych na indeksy $S \& P$ Index $(S P X)$ i Deutscher Aktienindex (DAX), akcjach Apple Inc. i Microsoft Corp. oraz kontraktach terminowych na towary High-Grade Copper (miedź) $i$ Crude Brent Oil (ropa). Wyniki i wnioski płynące ze wszystkich przypadków były zbieżne, więc ze względu na ograniczoną objętość pracy przedstawione zostaną tylko szczegółowe wyniki dla przypadku handlowania kontraktami na indeksy giełdowe. Zadaniem metod machine learningowych było znalezienie optymalnej strategii w okresie treningowym, obejmującym dzienne dane od początku 1998 do końca 2013 roku. Statystyki szeregów znajdują się w tabeli 1.

Ta b e l a 1. Statystyki opisowe szeregów SPX i DAX w okresie in-sample oraz out-of-sample

\begin{tabular}{|l|c|c|c|c|}
\hline \multirow{2}{*}{} & \multicolumn{2}{|c|}{ in-sample } & \multicolumn{2}{c|}{ out-of-sample } \\
\cline { 2 - 5 } & SPX & DAX & SPX & DAX \\
\hline \%ARC & 3.92 & 4.79 & 9.67 & 8.07 \\
\hline \%ASD & 20.39 & 24.97 & 11.94 & 0.44 \\
\hline IR & 0.19 & 0.19 & 0.81 & 29.27 \\
\hline \%MDD & 56.78 & 72.68 & 14.16 & 0.37 \\
\hline
\end{tabular}

Źródło: obliczenia własne. Tabela zawiera podstawowe statystyki opisujące efektywność badanych szeregów czasowych w okresie treningowym i walidacyjnym.

Skuteczność strategii otrzymanych w wyniku użycia metod była weryfikowana na okresie walidacyjnym, który trwał od początku 2014 do końca 2017 roku. Strategie operowały na częstotliwości dziennej, zajmując pozycję na koniec każdego dnia handlowego. Długość okresu treningowego była wystarczająca, aby uwzględnić różne stadia cyklu koniunkturalnego w testowanych szeregach czasowych. Długość okresu walidacyjnego pozwalała jednak na rzetelne zweryfikowanie działania strategii i poziomu przeoptymalizowania.

\subsection{Opis badania oraz przyjęte założenia}

W badanym okresie, od 1998 do 2017 roku następowały zmiany w kosztach transakcyjnych występujących na rynkach finansowych. Dla uproszczenia założono jednak stałe koszty transakcyjne - w analizowanym okresie każda 
transakcja wymagała opłaty transakcyjnej równej $0,25 \%$ jej wartości. Dodatkowo przyjęliśmy dźwignię finansową na poziomie $40 \%$, co oznacza, że każda rozważana strategia inwestowała $20 \%$ całkowitego salda rachunku w pojedyncze aktywo (łącznie 40\%). Rebalancing miał miejsce raz na 5 dni sesyjnych (czyli w każdym tygodniu kalendarzowym). Dostępne strategie zostały w pełni określone za pomocą czterech parametrów, określających długość średnich ruchomych. Przestrzeń parametrów $\Psi$ złożona jest $\mathrm{z}$ wektorów czterech liczb ze zbioru $\{1,5,10, \ldots, 100\}$.

\section{Wyniki}

Ze względu na losową naturę metody Extended Hill Climbing i Differential Evolution Method zostały wywołane 1000 razy, co pozwoliło na wyestymowanie parametrów rozkładów wyników i czasu obliczeń. Oprócz statystyk tych rozkładów przedstawiono linie equity strategii, które dawały kryterium optymalizacyjne na poziomie mediany ze wszystkich wywołań poszczególnych metod.

\subsection{Efektywność metod w okresie in-sample}

Wszystkie z rozpatrywanych metod machine learningowych uzyskały tę samą medianę kryterium optymalizacyjnego, różniącą się od najlepszego wyniku, osiąganego przez procedurę przeszukiwania wyczerpującego, dlatego reprezentować je będzie ta sama strategia. Można zaobserwować, że preferowane były bezpieczniejsze strategie o niższej ekspozycji na ryzyko, ze względu na uwzględnione w kryterium optymalizacyjnym dwie różne miary ryzyka oraz zastosowanie dźwigni. Warto zwrócić uwagę, że stopy zwrotu ze strategii były porównywalne do tych z instrumentu bazowego, przy kilkukrotnie niższej zmienności oraz wyjątkowo niskiej wartości maksymalnego obsunięcia kapitału - strategie nie straciły nigdy więcej niż $5 \%$ pozycji w ciągu całych 16 lat, kiedy indeksy traciły nawet $50 \%$ wartości. 
Ta be la 2. Parametry i statystyki strategii wybranych przez poszczególne metody

\begin{tabular}{|l|c|c|c|c|c|c|c|c|}
\hline & \multicolumn{4}{|c|}{ in-sample } & \multicolumn{4}{c|}{ out-of-sample } \\
\cline { 2 - 10 } & ES & EHC & GM & DEM & ES & EHC & GM & DEM \\
\hline p1 & 60 & 100 & 100 & 100 & 60 & 100 & 100 & 100 \\
\hline p2 & 45 & 35 & 35 & 35 & 45 & 35 & 35 & 35 \\
\hline p2.2 & 75 & 45 & 45 & 45 & 65 & 45 & 45 & 45 \\
\hline$\%$ ARC & 4.27 & 3.92 & 3.92 & 3.92 & -0.03 & -0.62 & -0.62 & -0.62 \\
\hline$\%$ ASD & 5.17 & 4.63 & 4.63 & 4.64 & 4.02 & 3.74 & 3.74 & 3.74 \\
\hline IR & 0.83 & 0.85 & 0.85 & 0.85 & -0.01 & -0.17 & -0.17 & -0.17 \\
\hline$\%$ MDD & 4.53 & 4.30 & 4.30 & 4.30 & 7.20 & 6.34 & 6.34 & 6.34 \\
\hline OC & 77.79 & 77.16 & 77.16 & 77.16 & 0.00 & -1.62 & -1.62 & -1.62 \\
\hline
\end{tabular}

Źródło: obliczenia własne. Tabela przedstawia wyniki dla testowanych metod w okresie in-sample (1998-2013) oraz w okresie out-of-sample dla pary kontraktów futures na indeksy giełdowe (SPX i DAX).

\section{Ry s u n e 1. Linie equity strategii wybranych przez poszczególne metody w okresie in-sample}

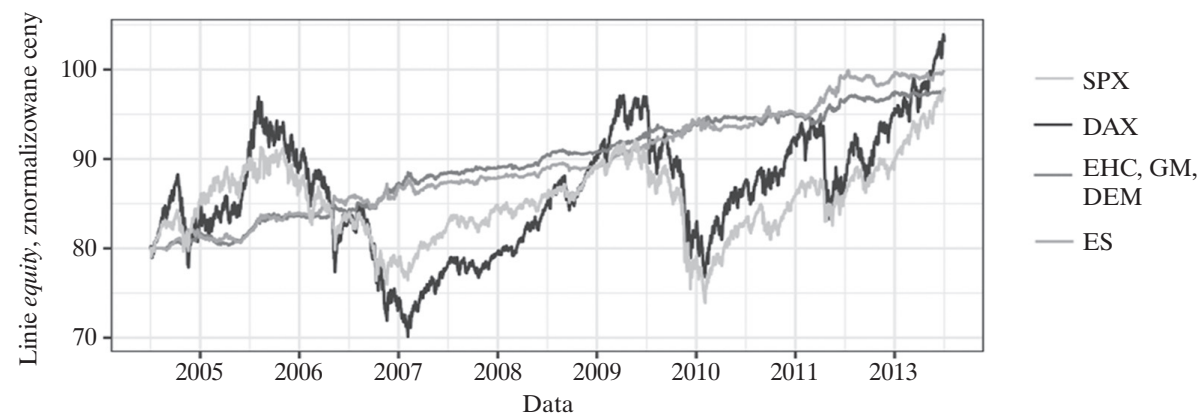

Źródło: obliczenia własne. Tabela przedstawia linie equity dla optymalnych parametrów testowanych metod w okresie in-sample (1998-2013) dla pary kontraktów futures na indeksy giełdowe (SPX i DAX).

Procedura wyszukiwania wyczerpującego zwróciła globalne maksimum w czasie 609.37 minut. Cechy rozkładów empirycznych kryterium optymalizacyjnego i czasu obliczeń z próbki 1000 wywołań metod EHC i DEM zostały 
przedstawione na histogramach z rysunku 2 oraz wraz z cechami rezultatów pozostałych metod w tabeli 3 . Większość niezależnych wywołań obu metod zwróciło ten sam wynik z drugim największym kryterium optymalizacyjnym, niewiele odbiegającym od najlepszego wyniku. Żadne z wykonań algorytmów nie zwróciło strategii zauważalnie gorszej od optymalnej, co wskazuje na wysoką wydajność i stabilność tych metod. Mediana czasu wykonania algorytmu EHC wynosiła 30.97 sekundy, natomiast DEM 31.15 sekundy, co stanowi nieporównywalnie mniej od czasu wykonania pełnego wyszukiwania wyczerpującego. W rozkładzie empirycznym czasu wykonania metody EHC widać spore zróżnicowanie, wynikające z zastosowanego mechanizmu dynamicznego zatrzymywania, które pozwala osiągać bardziej stabilne rezultaty kosztem stabilności czasowej. Nie mniej jednak nawet najdłuższy zaobserwowany czas oczekiwania był kilkadziesiąt razy krótszy od tego dla ES. Linie equity dla wybranych przez metody strategii zostały przedstawione na rysunku 1.

R y s u n e $k$ 2. Histogramy osiąganego kryterium optymalizacyjnego w okresie in-sample oraz czasu wykonania algorytmów EHC oraz DEM

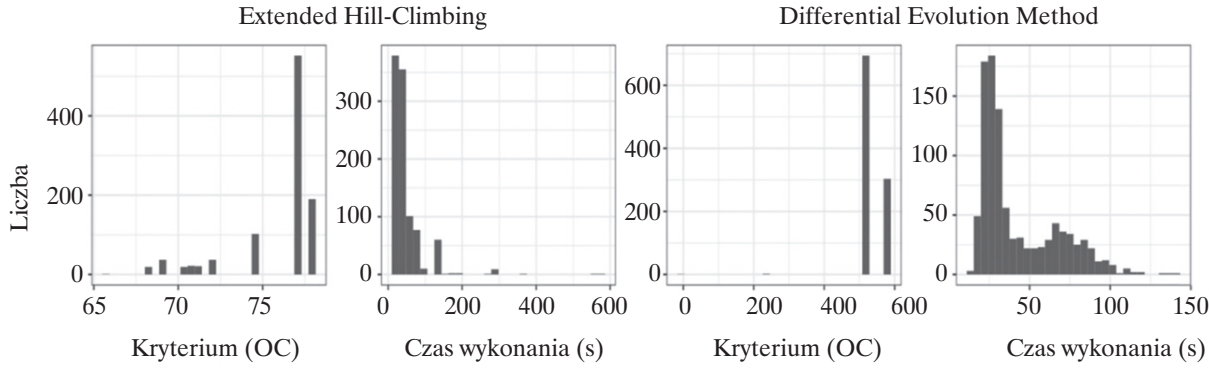

Źródło: obliczenia własne. Histogramy przedstawiają rozkład wyników kryterium optymalizacyjnego oraz czasu wykonania algorytmów EHC oraz DEM w okresie in-sample (1998-2013) dla pary kontraktów na SPX i DAX.

Metoda Grid zwróciła tę samą strategię, ale w nieco dłuższym czasie - 128,04 sekund, co jest wciąż dużo niższe niż dla metody ES (609.37 minut). Algorytm ten miał również dodatkowe zalety w stosunku do pozostałych metod - osiągane kryterium optymalizacyjne było identyczne, ale nie było niepewności co do wyników ani czasu, podczas gdy te wartości dla metod EHC i DEM były losowe. 
Ta b e la 3. Wybrane statystyki opisowe kryterium optymalizacyjnego i czasu wykonania metod

\begin{tabular}{|l|c|c|c|c|c|c|c|c|}
\hline \multirow{2}{*}{} & \multicolumn{2}{|c|}{ ES } & \multicolumn{2}{c|}{ EHC } & \multicolumn{2}{c|}{ GM } & \multicolumn{2}{c|}{ DEM } \\
\cline { 2 - 9 } & OC & Czas [s] & OC & Czas [s] & OC & Czas [s] & OC & Czas [s] \\
\hline Minimum & 77.79 & 36562.17 & 65.58 & 11.87 & 77.16 & 128.04 & 71.93 & 13.1 \\
\hline 1 kwantyl & 77.79 & 36562.17 & 74.39 & 13.93 & 77.16 & 128.04 & 77.16 & 24.84 \\
\hline Mediana & 77.79 & 36562.17 & 77.16 & 30.97 & 77.16 & 128.04 & 77.16 & 31.15 \\
\hline Średnia & 77.79 & 36562.17 & 75.94 & 43.10 & 77.16 & 128.04 & 77.34 & 42.73 \\
\hline 3 kwantyl & 77.79 & 36562.17 & 77.16 & 65.32 & 77.16 & 128.04 & 77.79 & 61.50 \\
\hline Maksimum & 77.79 & 36562.17 & 77.79 & 569.39 & 77.16 & 128.04 & 77.79 & 141.08 \\
\hline $\begin{array}{l}\text { Odchylenie } \\
\text { standardowe }\end{array}$ & 0.00 & 0.00 & 2.61 & 48.77 & 0.00 & 0.00 & 0.36 & 24.06 \\
\hline
\end{tabular}

Źródło: obliczenia własne. Tabela przedstawia wybrane statystyki opisowe kryterium optymalizacyjnego i czasu wykonania w okresie in-sample (1998-2013) dla pary kontraktów futures na indeksy giełdowe (SPX i DAX).

\subsection{Porównanie testowanych metod ML z ES}

Algorytmy uczenia maszynowego rozwiązały problem w znacznie krótszym czasie, a dodatkowo bez znaczących różnic w jakości wyników, w porównaniu z procedurami wyszukiwania wyczerpującego. Krytyczna różnica wstąpiła w czasie obliczeń. Sprawdzenie wszystkich możliwych parametrów wymagało dużo czasu (kilka do kilkunastu godzin), podczas gdy metody uczenia maszynowego dawały porównywalne wyniki w ułamku minuty. Przewaga w zakresie efektywności czasowej może okazać się kluczowa dla rozwiązywania złożonych problemów, np. cechujących się większą przestrzeń parametrów. Względna różnica czasu była znaczna - na przykład metoda DEM zajęła 1650 razy mniej czasu niż pełna procedura ES. Przyjmując taką samą proporcję, optymalizacja DEM, wykonywana w mniej niż jedną godzinę, mogłaby zastąpić metodę ES trwającą dwa miesiące.

Wyniki uzyskane w pracy sugerują, że wprowadzone w niej metody uczenia maszynowego mogą skutecznie zastąpić metodę wyszukiwania wyczerpującego, skracając czas obliczeń bez wpływu na jakość wyników (tabela 4). Analogiczne wyniki, jak dla kontraktów futures na indeks S\&P500 i DAX, zostały otrzymane dla pozostałych par testowanych aktywów finansowych.

W tabeli 4 widzimy, że podczas mediana i średnia kryterium optymalizacyjnego otrzymanego dla testowanych metod ML stanowi prawie $100 \%$ wartości dla metody ES, to czas potrzebny do wykonania obliczeń w ramach metod ML w stosunku do metody wyszukiwania wyczerpującego jest nawet o 1000 razy krótszy. 
Ta b e l a 4. Mediana i średnia kryterium optymalizacyjnego i czasu wykonania metod w stosunku do wyszukiwania wyczerpującego

\begin{tabular}{|l|c|c|c|c|c|c|c|c|}
\hline \multirow{2}{*}{} & \multicolumn{2}{|c|}{ ES } & \multicolumn{2}{c|}{ EHC } & \multicolumn{2}{c|}{ GM } & \multicolumn{2}{c|}{ DEM } \\
\cline { 2 - 9 } & OC [\%] & czas [\%] & OC [\%] & czas [\%] & czas [\%] & czas [\%] & czas [\%] & OC [\%] \\
\hline Mediana & 100 & 100 & 99.19 & 0.08 & 99.19 & 0.35 & 99.19 & 0.09 \\
\hline Średnia & 100 & 100 & 97.62 & 0.12 & 99.19 & 0.35 & 99.42 & 0.12 \\
\hline
\end{tabular}

Źródło: obliczenia własne. Tabela przedstawia kryterium optymalizacyjnego i czasu wykonania jako procent wyniku dla metody ES dla testowanych metod ML w okresie in-sample (1998-2013) dla pary kontraktów na SPX i DAX.

\section{Podsumowanie}

W pracy trzy metody uczenia maszynowego (EHC, GM oraz DEM) zostały przedstawione i przetestowane w zadaniu optymalizacji strategii przecięcia średnich kroczących. Omawiane metody bazują na podstawowych algorytmach wykorzystywanych do prostszych zagadnień, ale zostały rozszerzone i dopasowane do specyfiki problemu optymalizacji algorytmicznej strategii inwestycyjnej, która obejmuje dyskretność przestrzeni rozwiązań i dużą wrażliwość kryterium na zmianę parametrów. W pracy przedstawiono dokładne wyniki testów dla zadania optymalizacji strategii działającej jednocześnie na indeksach S\&P500 i DAX na danych dziennych w okresie od 1998 do 2013 roku.

Porównanie skuteczności metod uczenia maszynowego opierało się na porównaniu kryterium optymalizacyjnego strategii wybieranych przez nie oraz czasu ich wykonania. Kryterium bazowało na zannualizowanej stopie zwrotu, uwzględniając dodatkowo dwie miary ryzyka - zannualizowane odchylenie standardowe stóp zwrotu oraz maksymalne obsunięcie kapitału. Konstrukcja kryterium optymalizacyjnego, uwzględniająca miary ryzyka przełożyła się na wybranie bardziej stabilnych i obarczonych mniejszym ryzykiem strategii przez wszystkie metody. Użycie maksymalnego obsunięcia kapitału odpowiada za preferencje stabilnego zysku w czasie, wykluczając strategie generujące znaczną część zysku w krótkim okresie, co zmniejsza ryzyko zbyt mocnego dopasowania do danych historycznych i zwiększa szanse na działanie strategii w przyszłości.

Pierwsza metoda, o nazwie Extended Hill Climbing, zapewniała bardzo dobre i stabilne wyniki, porównywalne z optymalnymi, w stosunkowo krótkim, ale mało stabilnym czasie. Druga zaimplementowana metoda ML była czysto deterministycznym algorytmem, zwanym Metodą Siatki. Metoda zwróciła parametry strategii, z kryterium optymalizacyjnym podobnym do optymalne- 
go. Pomimo tego, że czas potrzebny na obliczenia był kilkukrotnie dłuższy niż dla dwóch innych niedeterministycznych metod ML, to jednocześnie stanowił jedynie ułamek czasu potrzebnego do procedury wyszukiwania wyczerpującego. Największą zaletą tej metody jest stabilny czas obliczeń i deterministyczne wyniki. Właściwości tej procedury optymalizacji można docenić zwłaszcza w przypadku zastosowania w bardziej złożonych, automatycznych systemach. Ostatnia metoda, zwana metodą ewolucji różnicowej (DEM), była w rzeczywistości jednym z najpopularniejszych algorytmów heurystycznych do rozwiązywania nieregularnych, parametryzowalnych problemów, dostosowanym do specyfiki przestrzeni parametrów całkowitych. Czas wykonania optymalizacji jest kluczowy dla praktyków, ze względu na potrzebę szybkiego podejmowania decyzji oraz jego bezpośrednie przełożenie na możliwość przetestowania szerszego zakresu, bardziej złożonych strategii.

Odnosząc się na koniec do postawionej na wstępie pracy głównej hipotezy badawczej, możemy powiedzieć, że zaproponowane metody uczenia maszynowego wymagały zdecydowanie mniej czasu niż metoda wyszukiwania wyczerpującego, osiągając bardzo zbliżone do niego wyniki. W konsekwencji hipoteza nie została odrzucona.

\section{Bibliografia}

Ardia, D., Boudt, K., Carl, P., Mullen, K.M. i Peterson, B.G. (2010). Differential Evolution with DEoptim: An Application to Non-Convex Portfolio Optimization. The R Journal, 3(1).

Ardia, D., Boudt, K., Carl, P., Mullem, K.M. i Peterson, B.G. (2011). Large-scale portfolio optimization with DEoptim. CRAN R. Pozyskano z https://cran.r-project.org/web/packages/ DEoptim/vignettes/DEoptimPortfolioOptimization.pdf.

Choundhry, R. i Kumkum, G. (2008). A Hybrid Machine Learning System for Stock Market Forecasting. International Journal of Computer and Information Engineering, 2(3).

Gunasekarage, A. i Power, D.M. (2001). The profitability of moving average trading rules in South Asian stock markets. Emerging Markets Review, 2(1), 17-33.

Hastie, T., Tibshirani, R. i Friedman, J.H. (2001). The Elements of Statistical Learning. Data Mining, Inference, and Prediction. New York: Springer-Verlag. Pozyskano z https://web. stanford.edu/ hastie/Papers/ESLII.pdf.

Hastie, T.,Tibshirani, R., James, G. i Witten, D. (2013). An Introduction to Statistical Learning: With Applications in R. New York: Springer-Verlag.

Mullen et. al. (2016). Package 'DEoptim' - Global Optimization by Differential Evolution. CRAN R Project. Pozyskano z https://cran.r-project.org/web/packages/DEoptim/vignettes/ DEoptim.pdf.

Samuel, A. (1959). Some Studies in Machine Learning Using the Game of Checkers. IBM Journal of Research and Development, 3(3), 210-229. 
Shen, S., Jiang, H. i Zhang, T. (2012). Stock Market Forecasting Using Machine Learning Algorithms., Stanford, CA: Department of Electrical Engineering, Stanford University, 1-5.

Stanković, J., Marković, I. i Stojanović, M. (2015). Investment Strategy Optimization Using Technical Analysis and Predictive Modeling in Emerging Markets. Procedia Economics and Finance, 19, 51-62.

Storn, R.M. i Price, K.V. (1997). Differential Evolution - A Simple and Efficient Heuristic for Global Optimization over Continuous Spaces. Journal of Global Optimization, 11, 341-359.

Storn, R.M., Price, K.V. i Lampinen, J.A. (2006). Differential Evolution - A Practical Approach to Global Optimization. Berlin Heidelberg: Springer-Verlag.

Valiant, L. (1984, November). A theory of the learnable. Communications of the ACM. https:// doi.org/10.1145/1968.1972. Pozyskano z http://web.mit.edu/6.435/www/Valiant84.pdf. 



\title{
Rozdział 5
}

\author{
ALFRED JANC*, KRZYSZTOF WALISZEWSKI**
}

\section{Poziom i struktura aktywów finansowych gospodarstw domowych w Polsce jako bariera rozwoju rynku kapitałowego - analiza w kontekście unii rynków kapitałowych}

W artykule dokonano prezentacji poziomu i struktury aktywów finansowych gospodarstw domowych w Polsce jako bariery dla rozwoju rynku kapitałowego w kontekście europejskiej unii rynków kapitałowych. Dokonano analizy znaczenia oszczędności gospodarstw domowych w ujęciu mikro- i makroekonomicznym, zaprezentowano unię rynków kapitałowych jako projekt kładący nacisk na transfer oszczędności w postaci lokat bankowy na rynek kapitałowy. Dokonano również prezentacji barier rozwoju rynku kapitałowego w Polsce z punktu widzenia inwestorów indywidualnych, a także sformułowano rekomendacje i niezbędne działania dla zwiększenia skali obecności inwestorów indywidualnych na rynku kapitałowym w Polsce. Określono również, na ile unia rynków kapitałowych jest w stanie zmniejszyć bariery rozwoju rynku kapitałowego w Polsce, a na ile są to decyzje wewnętrzne powiązane ze strategią rozwoju rynku kapitałowego wpisującą się w realizację programów rządowych.

Słowa kluczowe: oszczędności gospodarstw domowych, unia rynków kapitałowych, aktywa finansowe gospodarstw domowych, rynek kapitałowy.

prof. dr hab. Alfred Janc - Uniwersytet Przyrodniczy w Poznaniu, Wojska Polskiego 28, 60-624 Poznań, Polska; https://orcid.org/0000-0002-0654-1241.

** dr hab., prof. UEP Krzysztof Waliszewski - Uniwersytet Ekonomiczny w Poznaniu, Al. Niepodległości 10, 61-875 Poznań, Polska; https://orcid.org/0000-0003-4239-5875. 


\section{The Level and Structure of Household Financial Assets in Poland as a Barrier to Capital Market Development - Analysis in the Context of the Capital Markets Union}

The article presents the level and structure of financial assets of households in Poland as a barrier to the development of the capital market in the context of the European Union of Capital Markets. An analysis of the importance of household savings in micro- and macroeconomic terms was performed, the union of capital markets was presented as a project emphasizing the transfer of savings in the form of bank deposits to the capital market. The barriers to the development of the capital market in Poland were also discussed from the perspective of individual investors, and recommendations and necessary actions were formulated to increase the scale of the presence of individual investors on the capital market in Poland. It was also determined to which extent the capital markets union is able to reduce barriers to the development of the capital market in Poland, and to which extent these internal decisions are related to the capital market strategy in line with the implementation of government programs.

Keywords: household savings, capital markets union, household financial assets, capital market.

JEL: D53, D14, D15

\section{Wprowadzenie}

Jednym z etapów integracji Unii Europejskiej w obszarze finansowym, wdrażanym w latach 2015-2019 w poszczególnych krajach Wspólnoty, jest unia rynków kapitałowych (Capital Markets Union, CMU). Z założenia ma ona przyczynić się do większego wykorzystania przez przedsiębiorstwa z sektora MSP rynku kapitałowego do finansowania działalności, zapewnić większą dywersyfikację źródeł finansowania zdominowanych współcześnie przez środki własne i kredyt bankowy. Instrumentarium unii rynków kapitałowych dotyczy wielotorowych działań w zakresie aktywizacji podaży kapitału, popytu na kapitał oraz infrastruktury transakcyjnej i postransakcyjnej rynku kapitałowego. Celem referatu jest diagnoza poziomu i struktury aktywów finansowych gospodarstw domowych w Polsce jako wierzycieli netto oraz wykazanie, że struktura aktywów finansowych gospodarstw domowych stanowią istotną barierę w rozwoju rodzimego rynku kapitałowego, a sama unia rynków kapitałowych i jej narzędzia mogą tylko w niewielkim stopniu przyczynić się do większego wykorzystania przez nie rynku kapitałowego do lokowania nadwyżek finansowych, ponieważ większość problemów i barier ma charakter wewnętrzny. Artykuł ma charakter przeglądowy, opiera się na analizie literatury przedmiotu oraz danych statystycznych. W krajowej literaturze naukowej, tj. czasopismach i monografiach naukowych, znane są różne podejścia do analizy unii rynków kapitałowych, wśród których można wyróżnić następujące: analiza z perspek- 
tywy możliwości rozwoju alternatywnych źródeł finansowania i zagrożeń dla przedsiębiorstw (Szczepankowski, 2018; Pawłowski, 2017; Janc, Mikołajczak i Waliszewski, 2015); analiza komparatywna $\mathrm{z}$ innym projektem integracyjnym w obszarze finansowym strefy euro - unią bankową (Solarz, 2015; Waliszewski, 2015); perspektywy zmiany modelu bankowo zorientowanego systemu finansowego w UE pod wpływem unii rynków kapitałowych i zróżnicowania systemów finansowych państw członkowskich UE (Pisany i Dejneka, 2017; Janicka, 2018) czy analiza z punktu widzenia zagrożeń wynikających z unii rynków kapitałowych dla polskiego rynku kapitałowego (Waliszewski, 2017; Janc i Waliszewski, 2017; Albiński, 2017; Nieborak, 2017; Sroka, 2016) oraz spółdzielczych kas oszczędnościowo-kredytowych i banków spółdzielczych (Gostomski i Michałowski, 2016). Referat ten ma na celu wyznaczenie nowego wątku w dyskusji o unii rynków kapitałowych dotyczącego aktywów finansowych gospodarstw domowych i możliwości transferu oszczędności Polaków zgromadzonych w bankach na rynek kapitałowy. Należy podkreślić, że bez gospodarstw domowych i ich większego wykorzystania oszczędności na rynku kapitałowym nie uda się zbudować silnego rynku kapitałowego w Polsce ${ }^{1}$.

\section{Aktywa finansowe gospodarstw domowych w Polsce - poziom i struktura}

Poprzez aktywa finansowe gospodarstw domowych w dalszej części referatu autorzy rozumieją wszystkie formy gromadzenia finansowych nadwyżek finansowych w formach zarówno gotówki, jak i inwestycji bezpośrednich w papiery wartościowe czy zinstytucjonalizowanej poprzez tzw. instytucje wspólnego inwestowania. Aktywa finansowe gospodarstw domowych, których źródłem są oszczędności, odgrywają bardzo ważną rolę mikro- i makroekonomiczną. Sposób zarządzania tymi aktywami przyczynia się do skali zysków z kapitału w postaci odsetek, dywidend czy zysków kapitałowych, a przez to zwiększa dobrobyt gospodarstw oszczędzających. W ujęciu makroekonomicznym oszczędności gospodarstw domowych poprzez system finansowy są akumulowane i transformowane w inwestycje przedsiębiorstw, wpływając na wzrost

\footnotetext{
Aktualna giełdowa hossa na najważniejszych parkietach całego świata trwa od marca 2009 r. Ten „rynek byka” jest jednym z najdłuższych w historii światowego rynku kapitałowego. Giełdowemu „rynkowi byka” zawsze towarzyszą różnego rodzaju zagrożenia (czynniki ryzyka), które przeważnie wywołują korekty w trendzie wzrostowym. Jednak w końcu przychodzi moment, gdy zagrożenia zaczynają dominować i trend się zmienia. Hossa z lat 90. XX w. zakończyła się pęknięciem bańki spekulacyjnej na akcjach spółek internetowych notowanych na Wall Street. Hossa z początku XXI w. zakończyła się kryzysem na rynku nieruchomości w USA, który z kolei wywołał kryzys bankowy i w realnej gospodarce. Pojawia się pytanie, czym zakończy się aktualna hossa, której koniec wydaje się nieunikniony (Rosik, 2018).
} 
gospodarczy. Transformacja gospodarki Polski w 1989 r. oznaczała, że gospodarstwa domowe rozpoczęły naukę kultury oszczędzania i gospodarowania finansami osobistymi, której niezbędnym elementem jest edukacja formalna i pozaformalna, a efektem poziom wiedzy ekonomiczno-finansowej, postawy finansowe, zachowania finansowe i umiejętności finansowe. Wzrost zamożności polskiego społeczeństwa stwarzał możliwości coraz większego oszczędzania i odraczania konsumpcji w czasie, jednak, jak wskazują wyniki badania Fundacji Kronenberga za 2018 r., sporadyczne gromadzenie oszczędności deklaruje jedynie 53\% społeczeństwa (wzrost o 19 pp w stosunku do 2008 r.), oszczędzanie regularnie deklaruje zaś tylko $14 \%$ (w stosunku do 2008 r. oznaczało to podwojenie odsetka oszczędzających) (rysunek 1).

Ry s u n e 1. Odsetek Polaków oszczędzających regularnie i sporadycznie (w \%)

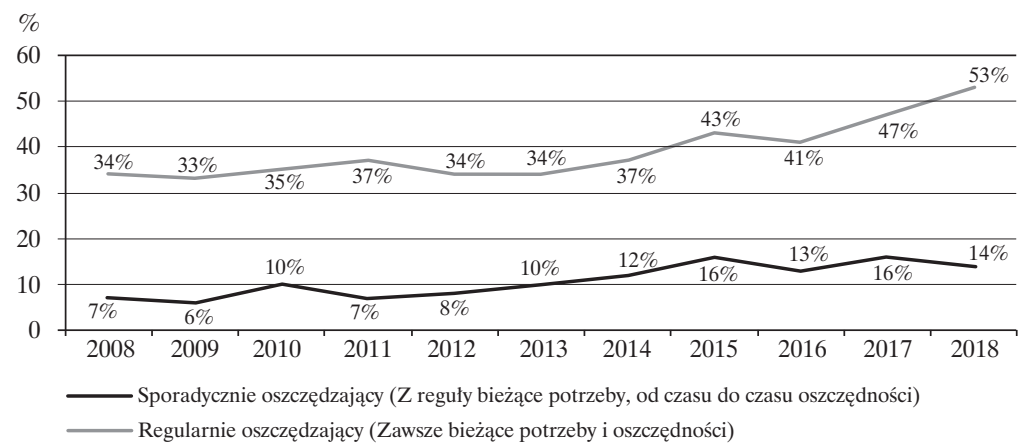

Źródło: Fundacja Kronenberga, 2018, lata 2008-2018.

Ry s u n e k 2. Stopa oszczędności brutto sektora gospodarstw domowych w krajach UE28 w latach 1999-2018 (w \%)

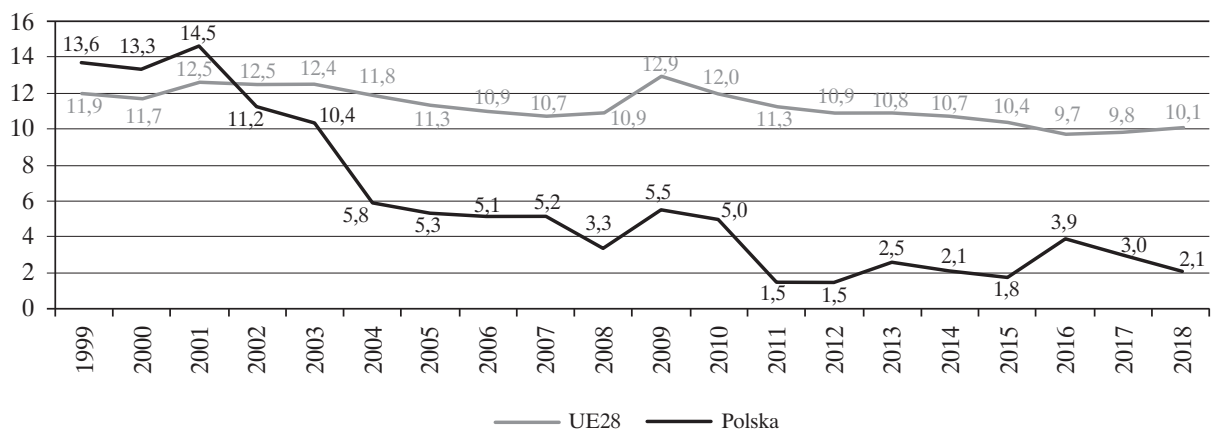

Źródło: Eurostat. 
Pomimo wzrostu bogactwa gospodarstw domowych związanego ze wzrostem dochodów, odsetek oszczędzających w Polsce jest bardzo niski. Biorąc pod uwagę porównania międzynarodowe z UE, Polska należy krajów z jedną z najniższych stóp oszczędności, która w latach 1999-2018 zmniejszyła się z 13,6 do 2,1\%, podczas gdy w UE w tym samym okresie następowało jej zmniejszenie z 11,9 do 10,1\%. Pod względem stopy oszczędności gospodarstw domowych Polska jeszcze w latach 1999-2001 znajdowała się na podobnym poziomie, jak duże państwa Unii Europejskiej, a nawet powyżej poziomu Hiszpanii oraz Wielkiej Brytanii. Od 2001 roku nastąpiło stopniowe obniżanie poziomu stopy oszczędności, aż do osiągnięcia jednego z najniższych poziomów w Unii Europejskiej w 2018 roku. Stopę oszczędności gospodarstw domowych zdefiniowano przy tym jako udział oszczędności brutto w dochodach do dyspozycji gospodarstw domowych brutto $\mathrm{z}$ uwzględnieniem korekty $\mathrm{z}$ tytułu zmiany udziałów netto gospodarstw domowych w rezerwach funduszy emerytalnych w danym roku (rysunek 2).

Efektem podejmowania przez gospodarstwa domowe w Polsce decyzji dotyczących przeznaczania bieżących dochodów częściowo na konsumpcję, częściowo zaś na oszczędności jest ukształtowanie się poziomu aktywów finansowych gospodarstw domowych tak w ujęciu bezwzględnym, jak i relatywnie w stosunku do PKB. W latach 1996-2018 aktywa finansowe gospodarstw domowych wzrosły ze 112 do 1448 mld zł (wzrost 13-krotny), a w stosunku do PKB z około 30 do około $70 \%$.

Ry s u n e 3. Wartość aktywów finansowych gospodarstw domowych (w mld zł) i w stosunku do PKB (w \%)

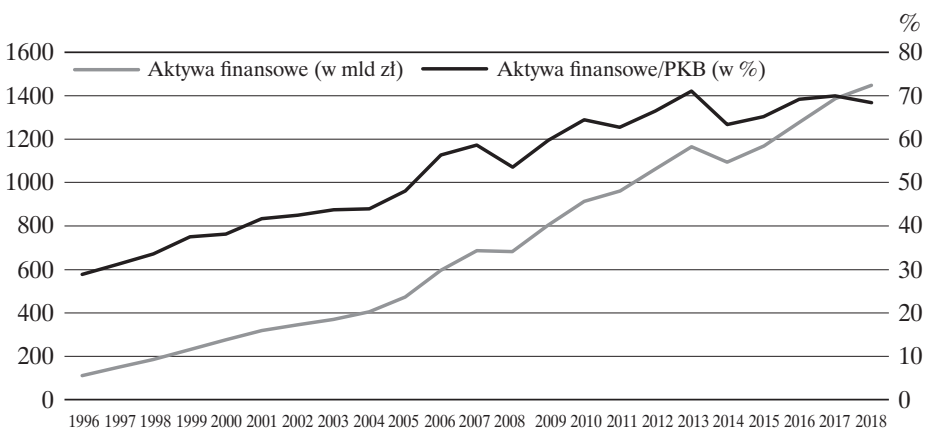

Źródło: opracowanie własne na podstawie danych: https://www.analizyonline.com/pl; GUS.

Wzrost aktywów finansowych gospodarstw domowych wynikał z jednej strony ze wzrostu poziomu oszczędności, z drugiej zaś - z przyrostu wartości rynko- 
wej aktywów finansowych. Problematyka obecności gospodarstw domowych na rynku kapitałowym może być rozpatrywana w dwóch płaszczyznach - inwestycji bezpośrednich jako inwestorów indywidualnych oraz inwestycji pośrednich w instytucjach zbiorowego inwestowania - towarzystwach funduszy inwestycyjnych i otwartych funduszach emerytalnych (rysunek 4).

\section{Ry s u n e 4. Formy obecności gospodarstw domowych na rynku kapitałowym}
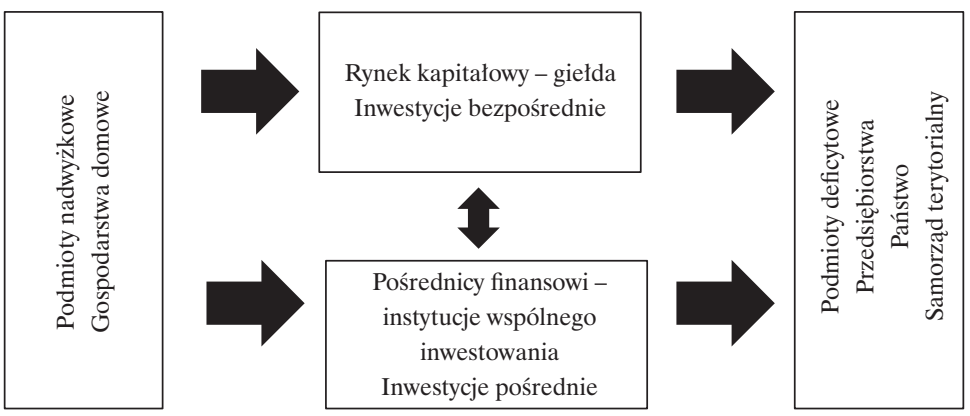

Źródło: opracowanie własne.

Ry s u n e 5. Struktura aktywów finansowych gospodarstw domowych (w \%)

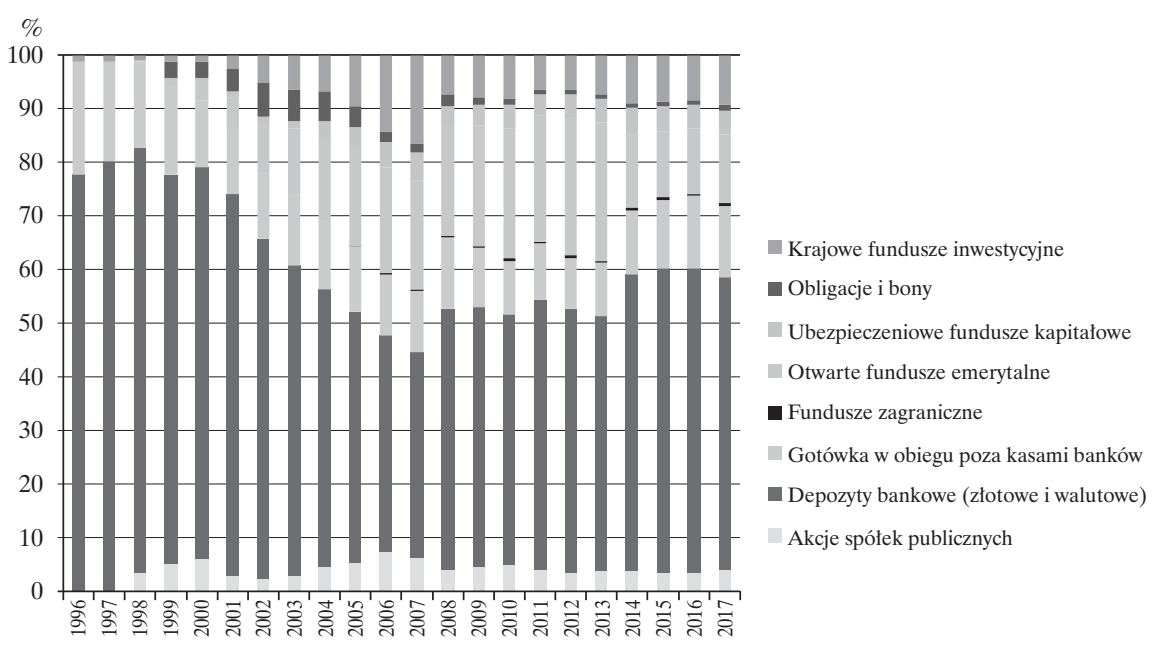

Źródło: opracowanie własne na podstawie danych: https://www.analizyonline.com/pl.

W strukturze aktywów finansowych gospodarstw domowych w Polsce (rysunek 5) znajdujemy odzwierciedlenie różnych czynników, wśród których do najważniejszych można zaliczyć następujące: 
- czynniki o charakterze ekonomicznym, podatkowym, demograficznym i psychologicznym oraz poziomem wiedzy finansowej;

- dominujący model systemu finansowego w Polsce - jest to model kontynentalny zorientowany bankowo, co wpływa na dominację depozytów bankowych w strukturze aktywów finansowych gospodarstw domowych (w $2017 \mathrm{r}$. udział depozytów wynosił 54\% i zmniejszył się od 1996 r. z poziomu 78\% z dominacją od końca 2014 r. depozytów bieżących nad depozytami terminowymi, co jest niekorzystne dla gospodarki z punktu widzenia finansowania długoterminowych inwestycji i wzrostu gospodarczego);

- rozwój systemu finansowego poprzez tworzenie nowych form pośrednictwa finansowego (OFE, TFI), które z czasem odgrywały coraz większą rolę w lokowaniu nadwyżek finansowych gospodarstw domowych, wypierając banki z dominującej instytucji pośrednictwa finansowego (tzw. dezintermediacja finansowa);

- coraz większe zróżnicowanie (dywersyfikacja) aktywów finansowych gospodarstw domowych;

- niski poziom edukacji finansowej polskiego społeczeństwa, w tym rozumienie relacji zysk-ryzyko oraz niski stopień akceptacji ryzyka, co przekłada się na niski udział inwestycji bezpośrednich w papiery wartościowe - akcje, bony i obligacje jako bardziej złożone instrumenty finansowe (Czekaj, 2017);

- wpływ koniunktury gospodarczej, w szczególności współczesnego kryzysu finansowego (2007-2009), który wpłynął na zmniejszenie udziału aktywów obarczonych ryzykiem $w$ formie inwestycji zarówno bezpośrednich, jak i pośrednich; w warunkach niskiego wzrostu gospodarczego preferowane są mniej ryzykowne aktywa finansowe (Utzig, 2013); udział depozytów bankowych systematycznie malał do połowy 2007 r., kiedy osiągnął swoją minimalną wartość na poziomie około 40\%, a następnie wzrastał do 2014 r. do poziomu około 55\%, natomiast kolejnych latach (2015-2017) obserwuje się stabilizację udziału depozytów na podobnym poziomie, co jest związane $\mathrm{z}$ relatywnie niską atrakcyjnością depozytów bankowych w środowisku niskich stóp procentowych (Klepacki, 2018);

- wpływ czynników politycznych - reforma emerytalna w 2014 r. i przekazanie 51,5\% aktywów zgromadzonych w OFE do ZUS w postaci polskich skarbowych papierów wartościowych o wartości ponad $153 \mathrm{mld}$ zł według cen rynkowych, po czym nastąpiło umorzenie tych walorów, co znacząco wpłynęło na wielkość długu publicznego Polski oraz gwałtownie zmieniło wartość i strukturę oszczędności finansowych gospodarstw domowych; w konsekwencji tych zmian udział OFE z 26\% w końcu 2013 r. zmniejszył 
się do 14\% w 2014 r. i do 2017 r. utrzymywała się tendencja spadkowa do poziomu $13 \%$;

- wpływ czynników podatkowych - wprowadzenie w 2002 r. opodatkowania odsetek i dochodów kapitałowych (tzw. podatek Belki) i tworzenie przez instytucje ubezpieczeniowe lokat antypodatkowych czy lokat z dzienną kapitalizacją odsetek;

- przywiązanie Polaków do gotówki, ponieważ gospodarstwa domowe w 2017 r. aż 13\% swoich aktywów gromadzą w gotówce poza kasami banków (w stosunku do 1996 r. nastąpiło zmniejszenie udziału o 8 pp).

Badania międzynarodowe na obszarze UE wskazują, że gospodarstwa domowe preferują lokowanie oszczędności w instrumentach płynnych, w szczególności w gotówce i krótkoterminowych depozytach bankowych oraz w instrumentach stabilnych ograniczających ryzyko typu polisy ubezpieczeniowe z funduszem kapitałowym. Taka struktura oszczędności nie jest korzystna dla gospodarek potrzebujących finansowania długoterminowego. Krótkoterminowe i płynne instrumenty lokacyjne nie są stabilną bazą do kreowania długoterminowych instrumentów finansujących (Korzeniowska, 2015). W porównaniu $\mathrm{z}$ UE w Polsce aktywa finansowe gospodarstw domowych zgromadzone w funduszach emerytalnych są stosunkowo niskie, udział inwestycji w akcje jest zbliżony. Porównując tę strukturę ze strukturą w Wielkiej Brytanii, gdzie występuje anglosaski, rynkowo zorientowany model systemu finansowego, można stwierdzić znacznie niższy udział depozytów i gotówki około $25 \%$ oraz blisko $60 \%$ udział funduszy emerytalnych.

Ry s u n e k 6. Struktura aktywów finansowych gospodarstw domowych w Polsce, UE i Wielkiej Brytanii w 2016 r. (w \%)

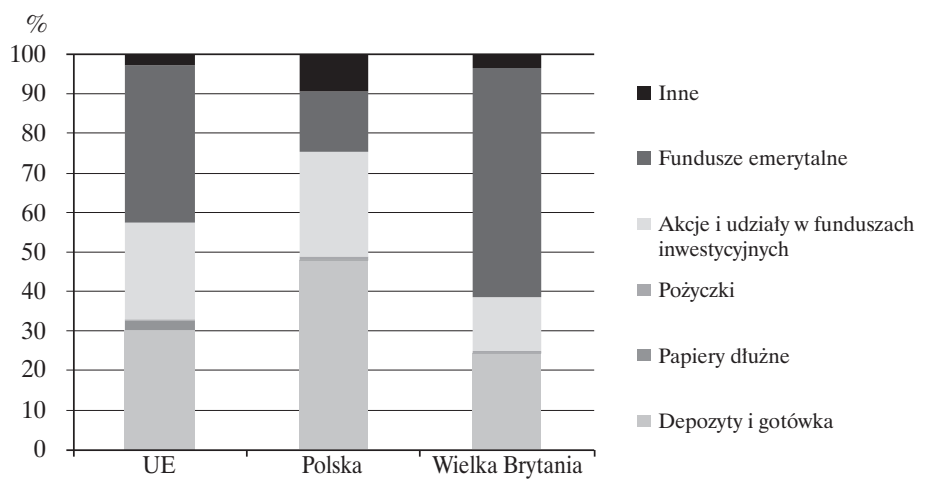

Źródło: Eurostat. 
Wartość aktywów finansowych gospodarstw domowych w relacji do PKB w ostatnich latach pozostaje na stabilnym poziomie w większości państw europejskich. Znacznie wyższy poziom aktywów posiadają gospodarstwa domowe z państw starej Unii Europejskiej i wynosi on od 150\% PKB do ponad 300\% PKB w Wielkiej Brytanii (Bondyra, Bosiacki i Żydok, 2017).

Stosując odniesienie do rynku bankowego i pojęcia wykluczenia finansowego, można byłoby sformułować pojęcie wykluczenia z rynku kapitałowego. Kto i jakie działania musiałby podjąć, by ten stan zmienić? Czy upływający czas, a wraz z nim postępujący wzrost zamożności rodzin z Polski, upodobni reakcje naszych drobnych inwestorów do tych, które znane są w społeczeństwach zamożnych - choćby z racji dążenia do zabezpieczania wartości aktywów poprzez ich dywersyfikację? A może popularyzacja dostępu elektronicznego i mobilnego do transakcji na giełdzie papierów wartościowych pozwoli ominąć niektóre fazy tego długotrwałego procesu? Przecież ostatnie dane pokazują jaką popularnością cieszy się bankowość mobilna, szczególnie wśród młodych. Może warto rozważyć podjęcie działań, które spopularyzują rynek kapitałowy, umożliwiając mobilną na nim obecność i jakieś formy inwestowania?

Odnosząc się do znaczenia papierów wartościowych w aktywach finansowych gospodarstw domowych, udział akcji spółek publicznych i obligacji oraz bonów kształtował się na relatywnie niskim poziomie, nieprzekraczającym $8 \%$ (rysunek 6). Szczególnie w przypadku akcji spółek publicznych uwidacznia się oddziaływanie czynników związanych z koniunkturą gospodarczą (kryzys milenijny, współczesny kryzys finansowy). Po kryzysie finansowym (2007-2009), gdy udział akcji był rekordowy (około 7\%), następował stopniowy spadek udziału akcji spółek publicznych do 4\%, a udział obligacji i bobów zmniejszył się do $1 \%$ (rysunek 7). Biorąc pod uwagę średnią dla krajów UE, łączny udział akcji oraz obligacji w aktywach finansowych gospodarstw domowych w Polsce wynosi około 5\%. Nadszarpnięte przez kryzys finansowy zaufanie do długoterminowych instrumentów rynku kapitałowego - akcji i obligacji nie zostało odbudowane w okresie analizy. 
Ry s u n e k 7. Udział akcji spółek publicznych, obligacji i bonów w aktywach finansowych gospodarstw domowych (w \%)

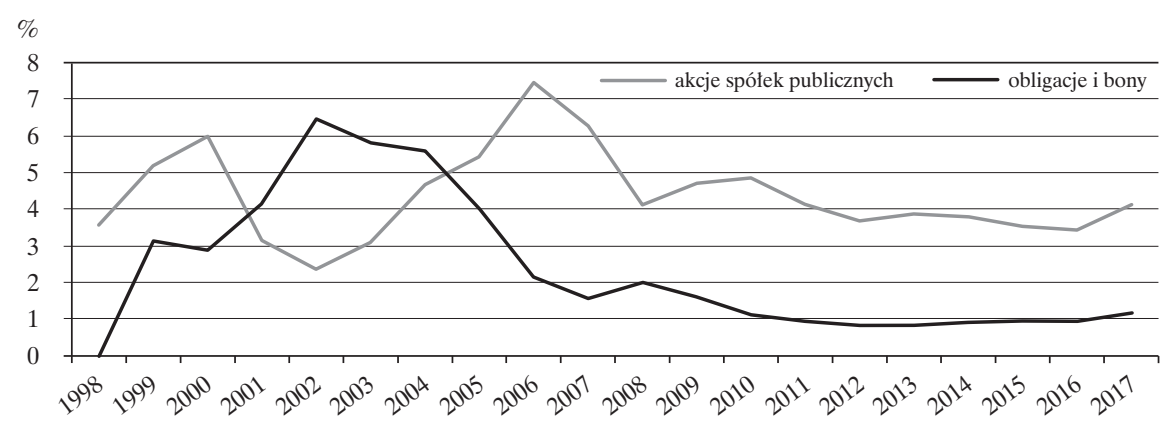

Źródło: opracowanie własne na podstawie danych: https://www.analizyonline.com/pl.

Poza inwestycjami bezpośrednimi w papiery wartościowe, które wymagaja odpowiedniej wiedzy ekonomiczno-finansowej oraz bieżącego zaangażowania w podejmowanie decyzji o kupnie i sprzedaży konkretnych walorów, drugą formą są inwestycje pośrednie (Barembruch, 2018). Gospodarstwa domowe, niedysponujące odpowiednią wiedzą ekonomiczno-finansową, chcąc dokonać inwestycji swoich oszczędności na rynku kapitałowym, mogą je powierzyć instytucjom zbiorowego inwestowania. Dane statystyczne wskazują na rosnący udział tych inwestycji do 2007 r. do maksymalnego poziomu ponad 35\%, a następnie spadek do ponad 20\% w 2017 r. jako efekt kryzysu finansowego (2007-2009) (rysunek 8). Dominują wśród nich instrumenty funduszy inwestycyjnych.

Ry s u n e 8. Udzial inwestycji pośrednich gospodarstw domowych w instytucjach wspólnego inwestowania

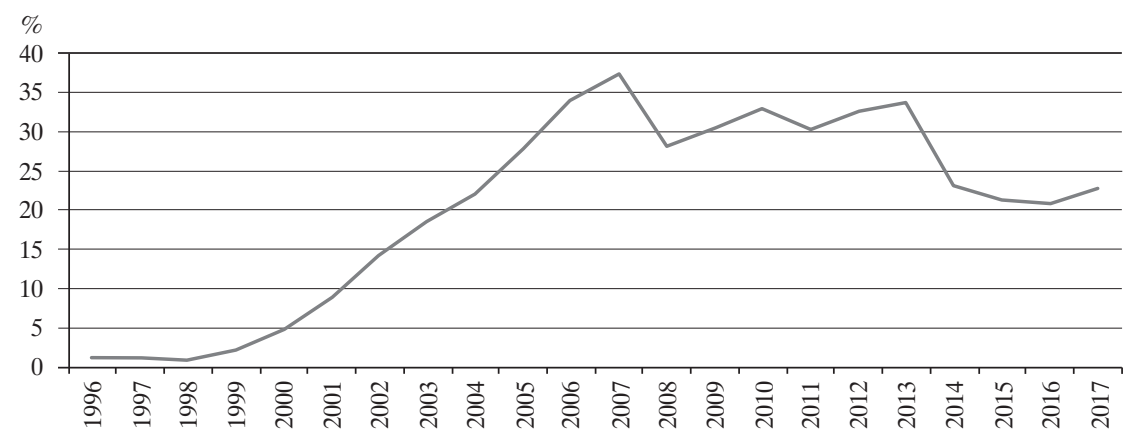

Źródło: opracowanie własne na podstawie danych: https://www.analizyonline.com/pl. 


\section{Oszczędności finansowe gospodarstw domowych jako niezbędny element powodzenia unii rynków kapitałowych}

W ramach projektu unii rynków kapitałowych założono, że wzmocnienie zaufania inwestorów detalicznych do rynków kapitałowych i pośredników finansowych mogłoby zwiększyć przepływ oszczędności z gospodarstw domowych w stronę instrumentów rynku kapitałowego, które to oszczędności w znacznym stopniu mają obecnie formę depozytów bankowych lub służą do finansowania nieruchomości. Zainteresowanie inwestorów detalicznych inwestowaniem bezpośrednio na rynkach kapitałowych jest zasadniczo małe w skali unijnej, ponieważ dokonuje się głównie za pośrednictwem zbiorowych inwestycji instytucjonalnych. Jednak europejskie gospodarstwa domowe mają znaczące oszczędności na rachunkach bankowych, które w niektórych przypadkach mogłyby być wykorzystywane bardziej produktywnie. Spadek stóp oprocentowania depozytów może zachęcić gospodarstwa domowe do przeniesienia większej części swoich zasobów finansowych z banków na rynek papierów wartościowych (Zielona Księga, 2015). Silniejsze rynki kapitałowe będą uzupełniały mocno zakorzenioną europejską tradycję finansowania bankowego i przyczynią się do uruchomienia większej liczby inwestycji z UE i pozostałej części świata: unia rynków kapitałowych pomoże gromadzić kapitał w Europie i przekazywać go wszystkim przedsiębiorstwom, w tym MŚP, na realizację projektów z zakresu infrastruktury i zrównoważonych projektów długoterminowych, którym kapitał ten jest potrzebny do rozwoju i tworzenia miejsc pracy. Dzięki temu gospodarstwa domowe będą miały lepsze możliwości realizacji swoich celów oszczędnościowych związanych z emeryturami (KE, 2015). Także w Polsce w środowisku niskich stóp procentowych i w konsekwencji słabej atrakcyjności depozytów bankowych istnieje potencjał do zwiększenia udziału w pośrednich i bezpośrednich inwestycjach na GPW. Oszczędności finansowe gospodarstw domowych transferowane $\mathrm{z}$ sektora bankowego są niezbędnym elementem rozwoju krajowego rynku kapitałowego, dlatego należy podejmować działania mające na celu:

- zwiększenia transparentności rynku kapitałowego, w tym giełdy papierów wartościowych;

- zwiększenia bezpieczeństwa inwestorów indywidualnych na rynku kapitałowym;

- zwiększenia poziomu wiedzy ekonomiczno-finansowej, w tym zasad funkcjonowania rynku kapitałowego, jego instrumentów, relacji między zyskiem i ryzykiem inwestycji w jego instrumenty; 
- zachęcenia Polaków do oszczędzania, w tym oszczędzania na konkretny cel, np.: zakup nieruchomości czy uzupełnienie emerytury;

- wzmocnienia motywów związanych z oszczędzaniem na emeryturę poprzez wsparcie państwa i pracodawców (vide Pracownicze Plany Kapitałowe);

- promowania inwestowania na rynku kapitałowym poprzez programy rządowe powiązane z preferencjami podatkowymi;

- wspólne inicjatywy instytucji rynku kapitałowego nakierowane na promowanie giełdy jako formy bezpośredniej i pośredniej oszczędzania na emeryturę.

\section{Ocena poziomu i struktury aktywów finansowych gospodarstw domowych w Polsce z punktu widzenia unii rynków kapitałowych}

Długoterminowe oszczędności emerytalne stanowią niewielką część aktywów Polaków, a struktura i wielkość oszczędności Polaków stanowią barierę dla zrównoważonego rozwoju gospodarki. Poziom oszczędności gospodarstw domowych w ujęciu bezwzględnym oraz w stosunku do PKB plasują Polskę wśród krajów o niższych wartościach tych wskaźników. Mimo to inwestorzy indywidualni stanowią zauważalną grupę na Warszawskiej Giełdzie Papierów Wartościowych. W zależności od segmentu rynku giełdowego udział inwestorów indywidualnych kształtował się na odmiennym poziomie - najniższy był w przypadku akcji na Rynku Głównym GPW (ponad 10\%), czyli największego segmenty rynku kapitałowego w Polsce, a największy w przypadku akcji na Rynku New Connect (blisko 80\%). W przypadku obligacji notowanych na rynku Catalyst w 2017 r. udział inwestorów indywidualnych wynosił blisko 40\% (rysunek 9).

Ry s u n e k 9. Udzial inwestorów indywidualnych w obrotach akcjami i obligacjami na GPW (w\%)

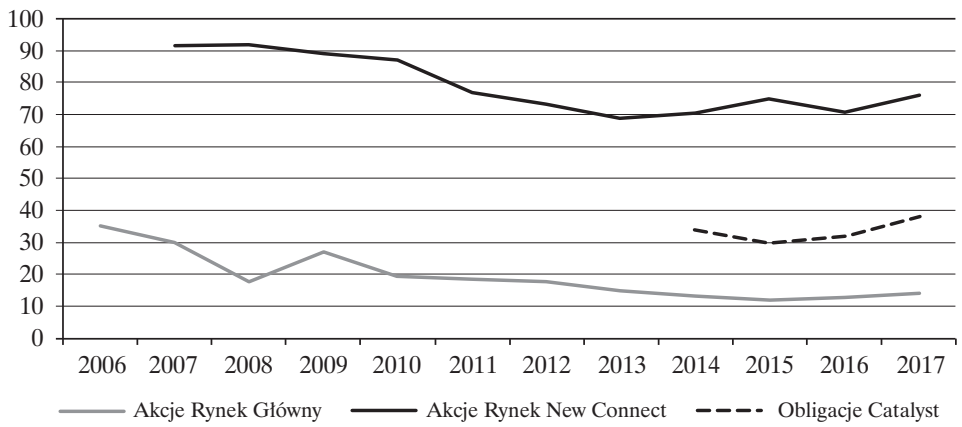

Źródło: statystyki GPW. 
Interesujących odpowiedzi na pytanie dotyczące relatywnie niskiej obecności gospodarstw domowych jako inwestorów indywidualnych na polskim rynku kapitałowym dostarcza badanie prowadzone przez Stowarzyszenie Inwestorów Indywidualnych wśród inwestorów na temat barier rozwoju i słabości polskiego rynku kapitałowego (rysunek 10).

Do najczęściej wymienianych słabości polskiego rynku kapitałowego należy zaliczyć:

- podatek od zysków kapitałowych;

- niski poziom edukacji finansowej;

- małą płynność;

- wysokie koszty transakcyjne;

- podatność na wahania rynków zagranicznych;

- przestępstwa na rynku kapitałowym.

Do rzadziej wymienianych słabości należy zaliczyć przestępstwa na rynku kapitałowym, niską jakość komunikacji spółek z inwestorami, złe uwarunkowania prawne czy niską jakość działania instytucji finansowych. W 2016 roku duże znaczenie (wskazane przez odsetek $43 \%$ inwestorów) odegrały czynniki polityczne i ich wpływ na rynek kapitałowy.

\section{Ry s u n e k 10. Największe słabości polskiego rynku kapitałowego w opinii inwestorów} indywidualnych

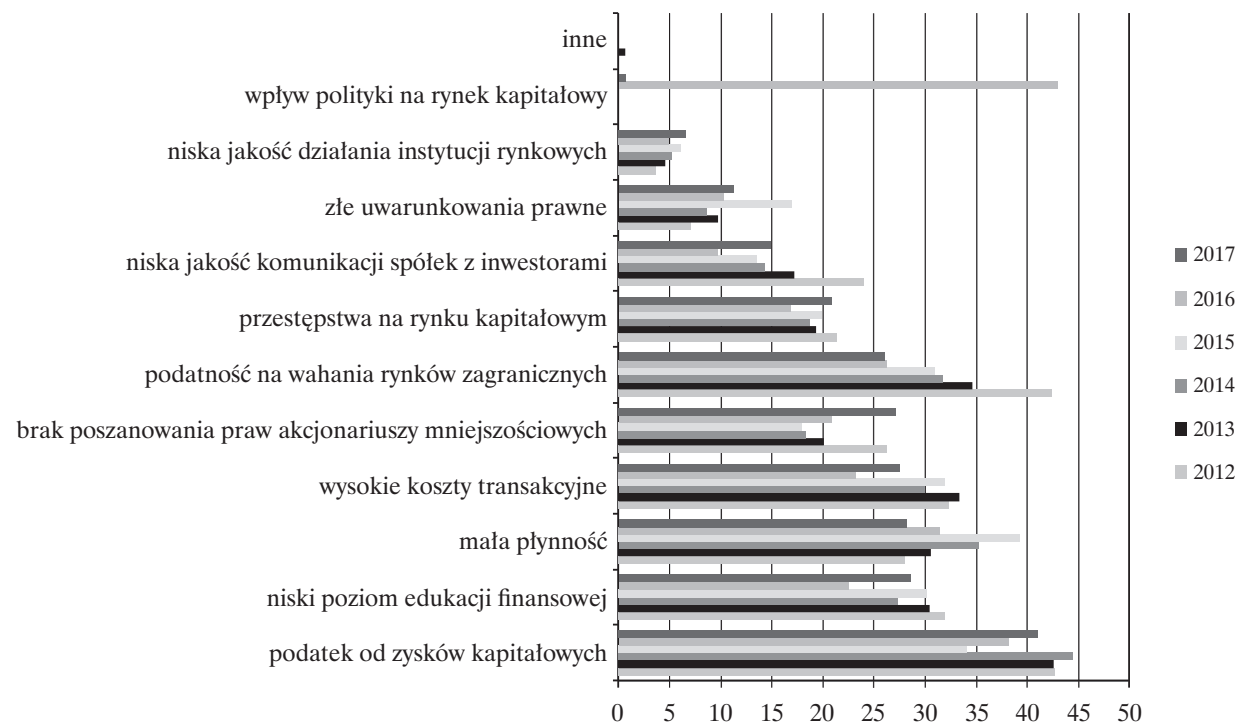

Źródło: OBI, 2012; 2013; 2014; 2015; 2016; 2017. 
Pojawia się pytanie, czy unia rynków kapitałowych będzie w stanie zneutralizować wymienione słabości i bariery w rozwoju rynku kapitałowego w Polsce. Jeśli poprzez unię rynków kapitałowych rodzimy rynek i giełda przyciągną atrakcyjnych emitentów, a przez to zwiększy się skala działania rynku kapitałowego, poprawie może ulec płynność, a obniżeniu koszty transakcyjne. Jednak większość z barier rozwoju polskiego rynku kapitałowego ma charakter ograniczeń wewnętrznych, a zatem ich przezwyciężenie powinno być zrealizowane w Polsce. Do najważniejszych działań w tym zakresie należy zaliczyć następujące (EFC i GOW, 2014; Czyżycki, 2016):

- szersze promowanie i wprowadzanie w obszar działań edukacyjnych i zawodowych standardów profesjonalnych i etycznych (w tym kontekście pojawia się pytanie, kto powinien takie działania edukacyjne realizować?);

- ograniczenie dostępu do możliwości świadczenia usług na rynku publicznym przez podmioty niespełniające tych standardów;

- stworzenie prostych, przyjaznych i powszechnie wykorzystywanych mechanizmów zachęcających do szerokiego wykorzystania przez obywateli narzędzi rynku kapitałowego do średnio- i długoterminowych inwestycji w polską gospodarkę (z wykorzystaniem mechanizmów podatkowych);

- stworzenie systemu profesjonalnej i przejrzystej oceny emitentów oraz monitorowania ryzyka na polskim rynku obligacji kierowanych na rynek publiczny, np. poprzez powołanie niezależnej instytucji odpowiedzialnej za realizację tych zadań;

- wprowadzenie zachęt podatkowych dla inwestycji długoterminowych (o okresie powyżej 5 lat) na rynku kapitałowym;

- wprowadzenie zachęt do długoterminowego oszczędzania na cel emerytalny w związku z malejącą stopą zastąpienia i rosnącą luką emerytalną.

Można przyjąć, że Pracownicze Plany Kapitałowe, które zostały wprowadzone od 1 lipca 2019 r. przez rząd, przyczynią się do wzrostu relacji oszczędności do $\mathrm{PKB}$, ale skala tego będzie mniejsza niż kilka punktów procentowych. Należy je zatem wprowadzić, ale bez przesadnych nadziei na pozytywny efekt makroekonomiczny.

\section{Podsumowanie}

W latach transformacji ustrojowej w Polsce petryfikowano przekonanie o słabościach systemu ZUS, nie stworzono jednak alternatywnego systemu z bodźcami do gromadzenia oszczędności. Nadal panuje przeświadczenie wśród polskich gospodarstw domowych, że inwestowanie oszczędności na rynku kapitałowym nie ma sensu, ponieważ polskie gospodarstwa domowe, 
pomimo wzrostu dochodów, pozostają nadal relatywnie ubogie w porównaniu z gospodarkami rozwiniętymi. Dodatkowo przy niskim poziomie wiedzy i aktywności na rynku finansowym nadal najczęściej preferowana jest klasyczna, bezpieczna lokata bankowa, która pozwala na zachowanie postawy pasywnej wobec posiadanych oszczędności. Afery związane z Amber Gold czy obecnie GetBack zniechęcają Polaków do lokowania oszczędności w inny niż klasyczny sposób w postaci lokaty bankowej. Obecny poziom i struktura aktywów finansowych gospodarstw domowych mają charakter antywzrostowy i nie sprzyjają zmianie struktury polskiej gospodarki. Nie ulega wątpliwości, że opracowana przez rząd we współpracy z EBOR strategia rozwoju polskiego rynku kapitałowego kładzie duży nacisk na zwiększenie skali obecności inwestorów indywidualnych na tym rynku. W tym celu niezbędne są działania edukacyjne i preferencje finansowe oraz podatkowe zachęcające do oszczędzania w ogóle, a także transferowania oszczędności z depozytów bankowych na rynek kapitałowy i gromadzenia kapitału na określony cel, w tym cel emerytalny. Konieczne jest zwiększenie transparentności rynku kapitałowego i zaufania uczestników do rynku, zwiększenie płynności, obniżenie kosztów transakcyjnych oraz poszanowanie praw akcjonariuszy mniejszościowych. Środowisko niskich stóp procentowych może oddziaływać korzystnie na większą aktywność inwestorów indywidualnych na rynku kapitałowym, a unia rynków kapitałowych wdrażana w UE do 2019 r. może zmniejszyć tylko niektóre bariery rozwoju polskiego rynku kapitałowego. Większość z nich musimy wyeliminować sami. Ciekawa byłaby analiza związków między poziomem i strukturą aktywów finansowych gospodarstw domowych z inicjatywami gospodarczymi tych podmiotów (przedsiębiorstwa rodzinne, start-upy, mikroprzedsiębiorczość) oraz ich finansowaniem w powiązaniu z wdrażaną unią rynków kapitałowych. Wątek ten może stanowić przyczynek do podjęcia badań w przyszłości.

\section{Bibliografia}

Albiński, P. (2017). Unia rynków kapitałowych. W: R. Bartkowiak, M. Matusewicz (red.), Paradygmaty w naukach ekonomicznych. Wyzwania XXI w. Warszawa: Oficyna Wydawnicza SGH.

Barembruch, A. (2018). Zarządzanie finansami osobistymi w Polsce. Teoria i praktyka. Gdańsk: Wydawnictwo Uniwersytetu Gdańskiego.

Bondyra, J., Bosiacki, M. i Żydok, R. (2017, listopad). Akumulacja kapitału w gospodarce Polski. Analiza czynników wplywających na poziom oszczędności gospodarstw domowych i jego skutków dla sektora przedsiębiorstw. Warszawa: Fundacja Republikańska.

Czekaj, J. i Kosidłowska A. (2017). Aktywa finansowe gospodarstw domowych i instytucji finansowych w Polsce. W: J. Czekaj (red.), Rynki, instrumenty $i$ instytucje finansowe. Warszawa: WN PWN. 
Czyżycki, R. (2016). Inwestor indywidualny na polskim rynku kapitałowym. Rozprawy $i$ Studia, MXXV(951). Szczecin: Wydawnictwo Naukowe Uniwersytetu Szczecińskiego.

EFC i GPW. (2014). Projekt Europejski Kongres Finansowy dla zrównoważonego rozwoju rynku kapitałowego w Polsce. European Financial Congres, Giełda Papierów Wartościowych w Warszawie. Pozyskano z https://docplayer.pl/586861-Projekt-europejski-kongresfinansowy-dla-zrownowazonego-rozwoju-rynku-kapitalowego-w-polsce.html.

Eurostat.

Fundacja Kronenberga, (2018, październik). Postawy Polaków wobec finansów. Badanie Fundacji Kronenberga przy Citi Handlowy i Fundacji Think!. Pozyskano z http://www. citibank.pl/poland/kronenberg/polish/files/raport_postawy_2018.pdf.

https://www.analizyonline.com/pl.

Janc, A. i Waliszewski, K. (2017). Quo vadis europejska unio rynków kapitałowych? W: T. Czerwińska, A.Z. Nowak (red.), Rynek kapitatowy - szanse i bariery. Warszawa: Wydawnictwo Naukowe Wydziału Zarządzania UW.

Janicka, M.A. (2018). Capital Market Union - Perspectives on Changes in the Financial System Model in the European Union. Acta Universitatis Lodziensis Folia Oeconomica, $1(333)$.

KE. (2015). Komunikat Komisji do Parlamentu Europejskiego, Rady, Europejskiego Komitetu Ekonomiczno-Społecznego i Komitetu Regionów. Plan działania na rzecz tworzenia unii rynków kapitałowych. Bruksela, 30.09.2015, COM(2015) 468 final.

Klepacki, J. (2018). Rola pośrednictwa finansowego w kształtowaniu struktury inwestycji gospodarstw domowych w ramach procesów inwestycyjnych. W: J.K. Solarz, J. Klepacki, K. Waliszewski, A. Trzaskowska-Dmoch, S. Wojciechowska-Filipek, Całościowa edukacja finansowa. Teoria i praktyka. Studia i Monografie, 82. Lódź-Warszawa: Społeczna Akademia Nauk.

Korzeniowska, A. (2015). Struktura oszczędności finansowych gospodarstw domowych w Polsce na tle wybranych krajów. Studia Ekonomiczne. Zeszyty Naukowe Uniwersytetu Ekonomicznego w Katowicach, 239.

Nieborak, T. (2017). Unia rynków kapitałowych UE - jako kolejny etap federalizacji rynku finansowego Unii Europejskiej? W: J. Gliniecka, A. Drywa, E. Juchniewicz, T. Sowiński (red.), Praktyczne i teoretyczne problemy prawa finansowego wobec wyzwań XXI wieku. Warszawa: CeDeWu.

OBI. (2012). Ogólnopolskie Badanie Inwestorów. Stowarzyszenie Inwestorów indywidualnych. Pozyskano z: https://www.sii.org.pl/4380/edukacja/badania-i-rankingi/ogolnopolskiebadanie-inwestorow-obi-2012.html.

OBI. (2013). Ogólnopolskie Badanie Inwestorów. Stowarzyszenie Inwestorów indywidualnych. Pozyskano z: https://www.sii.org.pl/6846/edukacja/badania-i-rankingi/ogolnopolskiebadanie-inwestorow-obi-2013.html.

OBI. (2014). Ogólnopolskie Badanie Inwestorów. Stowarzyszenie Inwestorów indywidualnych. Pozyskano z: https://www.sii.org.pl/7586/edukacja/badania-i-rankingi/ogolnopolskiebadanie-inwestorow-obi-2014.html.

OBI. (2015). Ogólnopolskie Badanie Inwestorów. Stowarzyszenie Inwestorów indywidualnych. Pozyskano z: https://www.sii.org.pl/8867/edukacja/badania-i-rankingi/ogolnopolskiebadanie-inwestorow-obi-2015.html\#ak8867.

OBI. (2016). Ogólnopolskie Badanie Inwestorów. Stowarzyszenie Inwestorów indywidualnych. Pozyskano z: https://www.sii.org.pl/11087/aktualnosci/aktualnosci/wyniki-ogolnopolskiego- 
badania-inwestorow-2016-najbardziej-przeszkadza-nam-wplyw-polityki-na-rynekkapitalowy.html\#ak11087.

OBI. (2017). Ogólnopolskie Badanie Inwestorów. Stowarzyszenie Inwestorów indywidualnych. Pozyskano z: https://www.sii.org.pl/11751/edukacja/badania-i-rankingi/ogolnopolskie-badanie-inwestorow-obi-2017.html\#ak11751.

Pawłowski, M. (2017). Unia rynków kapitałowych - szanse i zagrożenia z punktu widzenia rozwoju przedsiębiorstwa. Finanse. Rynki Finansowe, Ubezpieczenia, 4(88), cz. 2.

Pisany, P. i Dejneka, W. (2017, June). Europejska Unia Rynków Kapitałowych a zróżnicowanie systemów finansowych państw członkowskich. Catallaxy, 2(1), 13-25.

Rosik, P. (2018). Zagrożeń bez liku. Gazeta Bankowa, 7.

Solarz, J.K. (2015). Porównanie Unii bankowej z Unią rynków kapitałowych. Przyczynek do teorii hybrydowego pośrednictwa finansowego. W: B. Kożuch, J. Trippner-Hrabi (red.), Aspekty koncepcji zarzadzania humanistycznego w zarządzaniu publicznym. Warszawa, Łódź: Wyd. Społecznej Akademii Nauk.

Sroka, I. (2016). Unia Rynków Kapitałowych - wpływ na rynek kapitałowy w Polsce. W: T. Czerwińska, A.Z. Nowak (red.), Rynek kapitatowy - efektywność i ryzyko. Warszawa: Wydawnictwo Naukowe Wydziału Zarządzania UW.

Szczepankowski, P. (2018). Znaczenie unii rynków kapitałowych dla rozwoju alternatywnych źródeł finansowania małych i średnich przedsiębiorstw w Unii Europejskiej. Studia BAS, 1(53), 45-75.

Utzig, M. (2013). Aktywa finansowe gospodarstw domowych a koniunktura gospodarcza. Prace Naukowe Uniwersytetu Ekonomicznego we Wroctawiu, 305.

Waliszewski, K. (2017). Europejska unia rynków kapitałowych - szanse i zagrożenia realizacji w Polsce. Studia Oeconomica Posnaniensia, 5(8).

Waliszewski, K. (2015). Unia bankowa i unia rynków kapitałowych - analiza porównawcza europejskich projektów integracyjnych w obszarze finansowym. Nauki o Finansach, 2(23), 127-142.

Zielona Księga. Tworzenie unii rynków kapitałowych, COM/2015/063 final. 



\section{Rozdział 6}

TOMASZ ORLIK*

\section{Udział funduszy inwestycyjnych w oszczędnościach gospodarstw domowych w latach 2008-2018 w Polsce}

W artykule podsumowano wykorzystanie funduszy w oszczędnościach gospodarstw domowych oraz małą popularność dobrowolnych programów emerytalnych w przeddzień wprowadzenia Pracowniczych Programów Kapitałowych (PPK). Praca ma na celu zaprezentowanie danych z dziesięciu lat, czyli od kryzysu w roku 2007/2008 i pokazanie uwarunkowań, dlaczego fundusze inwestycyjne nie zyskały większego zainteresowania klientów, a ich udział wynosi jedynie ok. 10\% w oszczędnościach gospodarstw domowych. Wprowadzenie PPK będzie stymulowało rozwój funduszy, bezpośrednio poprzez przekazywanie składek oraz efekt synergii. Autor zakłada, że udział klientów w PPK przyczyni się do lepszego zrozumienia potrzeby i korzyści wynikających z długoterminowego oszczędzania. Instytucje finansowe, nawiązując relację z klientem w PPK, będą zaś miały ułatwioną możliwość sprzedaży innych produktów inwestycyjnych.

Słowa kluczowe: fundusze inwestycyjne, oszczędności, depozyty, oszczędności emerytalne, PPK, PPE, IKE, IKZE, FIO, SFIO, FIZ.

\section{The Investment Funds Participation in Household's Savings in 2008-2018 in Poland}

The article includes a comparison of the level of household savings in investment funds with the level of bank deposits during the period 2008 - 2018 in Poland. This is followed by a discussion regarding the reasons why there is a low growth of fund assets compared to deposits. Investment funds could be an interesting alternative for saving when the interest rate on bank's deposits is low, but no significant growth of the open-ended investment funds was observed. Assets of the retail investment funds increased to PLN 134 billion in December 2018, compared to household

mgr Tomasz Orlik - Szkoła Główna Handlowa, aleja Niepodległości 162, 02-554 Warszawa, Polska. 
deposits at PLN 828 billion. Other forms of household savings include: Bonds and Equities PLN 75.3 billion, Unit-linked Life Insurance PLN 50.4 billion and cash PLN 203 billion. At the end of 2018 this made up a total of PLN 1290.7 billion. The Author didn't include the assets of the third pillar Open Pension Funds, because these assets are a part of the Social Security System. Clients still avoid investment funds after the crisis of 2008, due to losses at the equity and balanced funds invested into Polish equities. The Warsaw Stock Exchange was also affected by the reform of the Third Pillar Pension Funds, redeeming 51.5\% of their assets into the Social Security System, and critics of the capital investments in 2014.

There were 63 Investment Fund Management Companies in Poland and a big variety of 1456 funds in 2018. They are divided, in terms of their legal forms, into following categories: 47 Open-ended (FIO Fundusze Inwestycyjne Otwarte), 52 Specialized Open-ended Funds (SFIO - Specjalistyczne Fundusze Inwestycyjne Otwarte) and 767 Closed-end (FIZ - Fundusze Inwestycyjne Zamknięte). In the framework of umbrella funds ( $\mathrm{FIO}$ and SFIO) there were 580 subfunds. Retail clients mainly invest into $\mathrm{FIO}$ and $\mathrm{SFIO}$ and only in a very small percentage in Closed-end funds.

The use of investment funds in supplementary pension system in Poland is also modest, due to very small overall participation in voluntary pension system. Assets of the Employee Pension Plans amounted to PLN 12.8 billion, Individual Pension Accounts had PLN 8.7 billion, while Individual Pension Saving Accounts (IKZE) PLN collected 2.3 billion. The Author discusses reasons of that situation and key factors for the future development. In particular, implementation of the Occupational Pension Schemes (PPK - Pracownicze Plany Kapitałowe) in 2019 can accelerate the growth of assets in investment funds and can stimulate the clients' interests in capital markets investments and saving in Poland. The key factor will also depend on improvement in investment performance. Implementation of the MIFIDII directive enforced more scrutiny in offering risk products for retail clients, better information regarding costs charged by the funds and fund's distributors as well as decrease of the management fees. It could improve sales of the investment funds compared to banking deposit in Poland.

Keywords: investment funds, savings, deposits, pension savings, PPK, occupational pension schemes, PPK, PPE, IKE, IKZE, FIO, SFIO, FIZ.

JEL: G2

\section{Wprowadzenie}

Fundusze inwestycyjne oferowane klientom indywidualnym umożliwiają wygodny sposób inwestowania oszczędności na rynku kapitałowym. Wiąże się to z możliwością osiągnięcia większych zysków niż na lokatach bankowych, ale obarczone jest również ryzykiem strat, co niejednokrotnie dzieje się w czasie bessy. W referacie podsumowano wykorzystanie funduszy w oszczędnościach gospodarstw domowych oraz małą popularność dobrowolnych programów emerytalnych w przeddzień wprowadzenia Pracowniczych Programów Kapitałowych (PPK) (Ustawa z dnia 4 października 2018 r. ...). 
Praca ma na celu zaprezentowanie danych z dziesięciu lat, czyli od kryzysu w roku 2007/2008 i pokazanie uwarunkowań, dlaczego fundusze inwestycyjne nie zyskały większego zainteresowania klientów, a ich udział wynosi jedynie ok. $10 \%$ w oszczędnościach gospodarstw domowych. Wprowadzenie PPK będzie stymulowało rozwój funduszy, bezpośrednio poprzez przekazywanie składek oraz efekt synergii. Autor zakłada, że udział klientów w PPK przyczyni się do lepszego zrozumienia potrzeby i korzyści wynikających z długoterminowego oszczędzania. Instytucje finansowe, nawiązując relację z klientem w PPK, będą zaś miały ułatwioną możliwość sprzedaży innych produktów inwestycyjnych.

Niski udział oszczędności zgromadzonych w funduszach w stosunku do depozytów bankowych upatruje się w wynikach, jakie fundusze dostarczały klientom w całym okresie 26-letniej historii w Polsce (Meluch, Nietrzepka i Orlik, 1993). Straty ponoszone przez fundusze akcyjne i mieszane w okresach bessy zniechęcały do inwestowania w kolejnych latach. Dyskusja na temat ryzyka, zysków i strat towarzyszy funduszom inwestycyjnym od ponad dziewięćdziesięciu lat na rykach rozwiniętych, a w dalszym ciągu potrzebna jest edukacja inwestorów. Kolejne przepisy, jak np. dyrektywa MIFID II, wymuszają na instytucjach finansowych większą staranność przy oferowaniu funduszy klientom oraz dopasowanie ryzyka inwestycyjnego do profilu i wieku klienta. Zmiany będą procentować w najbliższych latach, ponieważ wprowadzą obniżenie i przejrzystość kosztów, a także popularyzację funduszy, które będą przejściowo generowały mniejsze zyski dla instytucji finansowych, ale zwiększą atrakcyjność dla klientów w dłuższym okresie.

Działalność funduszy inwestycyjnych na rynkach rozwiniętych była często przedmiotem krytyki i dyskusji na temat wpływu funduszy na spekulacyjne wzrosty na rynkach kapitałowych, doprowadzanie do baniek spekulacyjnych, krachów i strat dla klientów. Przykłady z USA lub krajów Unii Europejskiej pokazują, że skokowy wzrost popularności funduszy inwestycyjnych następował po wprowadzaniu przepisów stymulujących długoterminowe oszczędzanie emerytalne oraz wprowadzanie zachęt podatkowych (Henriques, 1997).

Mamy w Polsce dużą różnorodność funduszy, których liczba wyniosła 1456 (razem z subfunduszami; dane NBP z grudnia 2018 r.) (www.nbp.pl/home. aspx?f=/statystyka/pieniezna_i_bankowa/sfi.html) i ze względu na formę prawną dzieliły się na: 47 Funduszy Inwestycyjnych Otwartych (FIO), 52 Specjalistyczne Fundusze Inwestycyjne Otwarte (SFIO) oraz 767 Funduszy Inwestycyjnych Zamkniętych (FIZ). W ramach tzw. parasolowych funduszy FIO oraz SFIO funkcjonowały 580 subfundusze. Oszczędności klientów indywidualnych trafiają głównie do FIO oraz SFIO, a w niewielkim zakresie również do 
FIZ dedykowanych dla klientów indywidualnych. Na rysunku 1 przedstawiono podział funduszy ze względu na formę prawną oraz wyróżniono fundusze detaliczne oferowane klientom indywidualnym.

Ry s u n e 1. Klasyfikacja funduszy inwestycyjnych

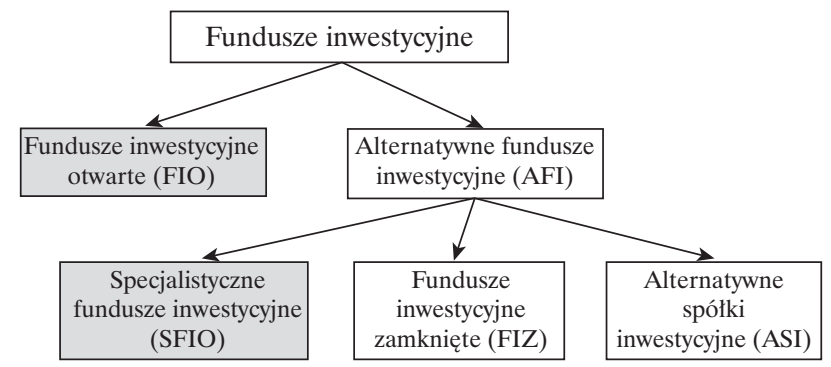

Źródło: opracowanie własne.

Potocznie mówi się, że dla inwestorów indywidualnych przeznaczone są tzw. fundusze detaliczne, a klienci instytucjonalni inwestują w fundusze niedetaliczne. Przeważająca cześć aktywów funduszy zamkniętych zgromadzona jest przez klientów instytucjonalnych. Podział aktywów na fundusze detaliczne i niedetaliczne w latach 2008-2018 w Polsce pokazano na rysunku 2. Widać na nim, że od 2011 roku aktywa funduszy niedetalicznych przyrastały szybciej niż funduszy dla klientów indywidualnych, a następnie w latach 2017 i 2018 nastąpił odpływ aktywów z funduszy niedetalicznych. Z łącznej wartości 256,7 mld zł zgromadzonych w funduszach, ponad połowę (134 mld zł) stanowiły fundusze niedetaliczne (na koniec 2018 roku).

Ry s u n e 2 . Wartość aktywów funduszy detalicznych i niedetalicznych w okresie od grudnia 2008 do grudnia 2018 roku

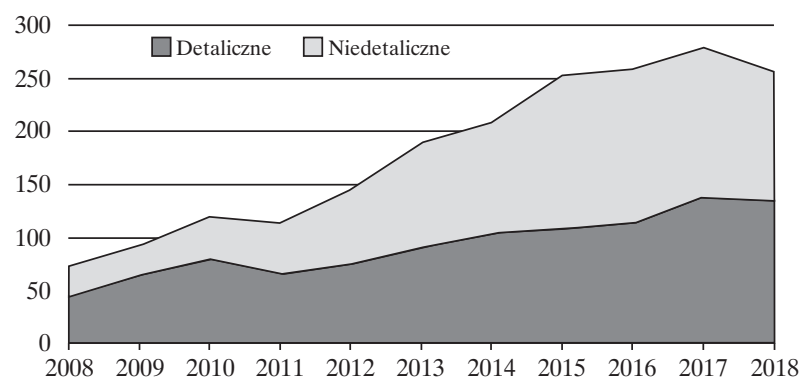

Źródło: https://www.analizyonline.com/pl. 
W 2018 r. funkcjonowały 63 towarzystwa funduszy inwestycyjnych w Polsce oferujące szeroką gamę funduszy o bardzo różnych strategiach, począwszy od bezpiecznych funduszy pieniężnych, poprzez fundusze o zrównoważonych strategiach akcyjno-obligacyjnych, aż do funduszy akcyjnych inwestujących w spółki o dużym ryzyku. Jest też duża oferta funduszy inwestujących na rynkach światowych lub w surowce. W tabeli 1 podany jest profil inwestycyjny funduszy (łącznie detalicznych i niedetalicznych) oraz ich udział w aktywach ogółem na koniec grudnia 2018 roku.

Ta be la 1. Aktywa netto poszczególnych kategorii funduszy i ich udział w rynku w czerwcu 2018 roku

\begin{tabular}{|l|c|c|}
\hline \multicolumn{1}{|c|}{ Kategorie } & Aktywa (mld) & Udzial \\
\hline Akcji & 25,4 & $9,9 \%$ \\
\hline Mieszane & 29,2 & $11,4 \%$ \\
\hline Dłużne & 44,7 & $17,4 \%$ \\
\hline Gotówkowe i pieniężne & 56,3 & $21,9 \%$ \\
\hline Absolutnej stopy zwrotu & 8,9 & $3,5 \%$ \\
\hline Rynku surowców & 0,8 & $0,3 \%$ \\
\hline Nieruchomości & 2,3 & $0,9 \%$ \\
\hline Sekurytyzacyjne & 4,9 & $1,9 \%$ \\
\hline Aktywów niepublicznych & 84,2 & $32,8 \%$ \\
\hline Razem & $\mathbf{2 5 6 , 7}$ & $\mathbf{1 0 0 \%}$ \\
\hline
\end{tabular}

Źródło: https://www.analizyonline.com/pl.

Po wyłączeniu funduszy aktywów niepublicznych, które przeznaczone są dla klientów instytucjonalnych można zauważyć, że rynek zdominowanych jest przez bezpieczne fundusze dłużne i pieniężne. W ostatnim roku obserwowaliśmy odkupienia z funduszy akcyjnych i mieszanych oraz napływy do funduszy obligacji, co potwierdza dużą awersję do ryzyka inwestorów.

W strukturze oszczędności Polaków zdecydowanie przeważają lokaty bankowe. W dużym stopniu jest to spowodowane obawą przed ryzykiem spadków na giełdach i strat na funduszach. Często poparte jest również przykrymi doświadczeniami i stratami, które miały fundusze akcyjne i mieszane w okresach bessy na rynkach kapitałowych. Około 2,3 milionów klientów indywidualnych oszczędzało w funduszach w Polsce na koniec 2018 roku. W badaniach 
Diagnoza Społeczna 7,7\% respondentów zadeklarowało, że posiada oszczędności w funduszach inwestycyjnych w 2015 roku (Czapiński i Panek, 2015, s. 57-72).

Badając dotychczasowy rozwój i prognozując przyszłość funduszy inwestycyjnych, należy wziąć pod uwagę strukturę oszczędności finansowych gospodarstw domowych i na tym tle pokazać udział funduszy jako alternatywną formę lokowania oszczędności. Dane na temat oszczędności gospodarstw domowych w Polsce zawarte są w badaniu Diagnoza Społeczna z 2009, 2011, 2013 oraz 2015 roku. Badanie oszczędności z poziomu gospodarstwa domowego pokazuje interesujące zależności w gospodarstwie domowym, gdzie są wspólne plany odnośnie do wydatków i oszczędzania.

Większość Polaków uważała, że warto oszczędzać, ale pomimo tej deklaracji jedynie $45 \%$ rodzin posiadało oszczędności finansowe. Gospodarstwa domowe, które deklarowały posiadanie oszczędności, najczęściej gromadziły je jako: rezerwę na sytuacje losowe (ponad $71 \%$ gospodarstw), zabezpieczenie na starość (pawie $40 \%$ gospodarstw) oraz jako rezerwę na bieżące wydatki konsumpcyjne (ponad 33\% gospodarstw).

W dalszym ciągu dominują gospodarstwa z oszczędnościami ok. trzymiesięcznych dochodów. Odsetek posiadających oszczędności w wysokości powyżej rocznych dochodów pozostaje na niskim poziomie 7,9\%, co oznacza, że w populacji wszystkich gospodarstw domowych stanowią one jedynie 3,5\%. Pozostałe gospodarstwa, które zadeklarowały posiadanie oszczędności przyznają, że ich poziom jest niewielki i 19,7\% z nich deklaruje oszczędności w wysokości jednomiesięcznych dochodów, 32,1\% rodzin ma oszczędności równe trzymiesięcznym dochodom, 24,6\% rodzin ma oszczędności równie 3-6 miesięcznym dochodom, a 15,7\% powyżej półrocznych, do rocznych dochodów.

$\mathrm{Z}$ badań Diagnoza Społeczna wiemy, że prawie połowa Polaków kieruje się własną intuicją $w$ decyzjach o tym, jak oszczędzać lub ewentualnie korzysta $z$ opinii znajomych i rodziny. Potrzeba edukacji na temat finansów osobistych oraz oszczędzania nadal jest duża, instytucje finansowe mają zaś duży obszar potencjalnych i ciekawych relacji z klientami.

\section{Struktura oszczędności gospodarstw domowych}

Wartość oszczędności gospodarstw domowych wyniosła 1290,7 mld złotych w grudniu 2018 r., co oznacza, że oszczędności przyrastały średnio w tempie 10,4\% rocznie w ciągu ostatniej dekady. Zestawienie oszczędności gospodarstw domowych zaprezentowano w podziale na pięć podstawowych kategorii $\mathrm{w}$ tabeli 2 . W ciągu dekady nominalna wartość depozytów bankowych 
gospodarstw domowych wzrosła z 332 mld zł w grudniu 2008 r. do 828 mld zł na koniec 2018 roku. W tym czasie aktywa funduszy inwestycyjnych (posiadanych przez osoby fizyczne) wzrosły z 44,4 mld do 134 mld zł i ich udział wyniósł 10,4\% ogółu oszczędności w 2018 roku.

Polacy mieli również ok. 50,4 mld zł zgromadzonych w Ubezpieczeniowych Funduszach Kapitałowych, które na potrzeby artykułu klasyfikowano oddzielnie, ponieważ klienci związani są dodatkowo polisami ubezpieczeniowymi na życie (Orlik, 2015). W strukturze oszczędności nie uwzględniono aktywów zgromadzonych w otwartych funduszach emerytalnych, ponieważ stanowią one element systemu ubezpieczeń społecznych, chociaż planowane jest ich przekształcenie w Indywidualne Konta Emerytalne (IKE).

Ta b e la 2. Struktura oszczędności gospodarstw domowych w Polsce (mld PLN)

\begin{tabular}{|l|c|c|c|c|c|c|c|c|c|c|c|}
\hline \multicolumn{1}{|c|}{ Rodzaj } & $\mathbf{2 0 0 8}$ & $\mathbf{2 0 0 9}$ & $\mathbf{2 0 1 0}$ & $\mathbf{2 0 1 1}$ & $\mathbf{2 0 1 2}$ & $\mathbf{2 0 1 3}$ & $\mathbf{2 0 1 4}$ & $\mathbf{2 0 1 5}$ & $\mathbf{2 0 1 6}$ & $\mathbf{2 0 1 7}$ & $\mathbf{2 0 1 8}$ \\
\hline $\begin{array}{l}\text { Inwestycje } \\
\text { bezpórednie } \\
\text { (obligacje, akcje)* }\end{array}$ & 40,2 & 50,4 & 54,7 & 48,4 & 46,6 & 54,4 & 51,2 & 51,8 & 58,0 & 73,4 & 75,3 \\
\hline $\begin{array}{l}\text { Fundusze } \\
\text { inwestycyjne } \\
\text { (dla osób } \\
\text { fizycznych)** }\end{array}$ & 44,4 & 65,2 & 79,4 & 66,0 & 74,8 & 91,0 & 103,5 & 108,0 & 114,0 & 137,2 & 134,0 \\
\hline $\begin{array}{l}\text { Ubezpieczeniowe } \\
\text { fundusze } \\
\text { kapitałowe }\end{array}$ & 25,8 & 31,0 & 36,4 & 37,5 & 45,1 & 50,1 & 54,0 & 55,5 & 57,0 & 59,6 & 50,4 \\
\hline $\begin{array}{l}\text { Depozyty złotowe } \\
\text { i walutowe }\end{array}$ & 332,0 & 387,6 & 426,0 & 482,1 & 519,5 & 553,7 & 605,3 & 662,5 & 725,0 & 752,6 & 828,0 \\
\hline Gotówka w obiegu & 90,7 & 89,8 & 92,7 & 101,8 & 102,5 & 114,4 & 130,0 & 149,7 & 174,4 & 184,3 & 203,0 \\
\hline Razem & $\mathbf{5 3 3 , 1}$ & $\mathbf{6 2 4 , 0}$ & $\mathbf{6 8 9 , 2}$ & $\mathbf{7 3 5 , 8}$ & $\mathbf{7 8 8 , 5}$ & $\mathbf{8 6 3 , 6}$ & $\mathbf{9 4 4}$ & $\mathbf{1 0 2 7}$ & $\mathbf{1 1 2 8}$ & $\mathbf{1 2 0 7}$ & $\mathbf{1 2 9 0 , 7}$ \\
\hline
\end{tabular}

* akcje i obligacje w posiadaniu gospodarstw domowych wg NBP;

** dostępne dla osób fizycznych, skorygowane o wartość inwestycji ubezpieczycieli.

Źródło: https://www.analizyonline.com/pl.

Podział oszczędności finansowych na: akcje i obligacje posiadane bezpośrednio, fundusze inwestycyjne, ubezpieczeniowe fundusze kapitałowe, depozyty i gotówkę zaprezentowany został na rysunku 3. Kryzys na rynkach finansowych w roku 2008 spowodował znaczne zmniejszenie wartości funduszy inwestycyjnych oraz akcji i obligacji posiadanych przez klientów indywidualnych. Z porównania danych z końca 2007 r. wynika, że nastąpił spadek aż o $60 \%$ aktywów funduszy inwestycyjnych oraz wzrost depozytów o $26 \%$ w ciagu 
jednego roku 2008. Wielu klientów w czasie kryzysu odkupiło jednostki funduszy i przeniosło środki na lokaty.

Ry s u n e 3. Procentowy udzial różnych aktywów finansowych gospodarstw domowych w latach 2008-2018

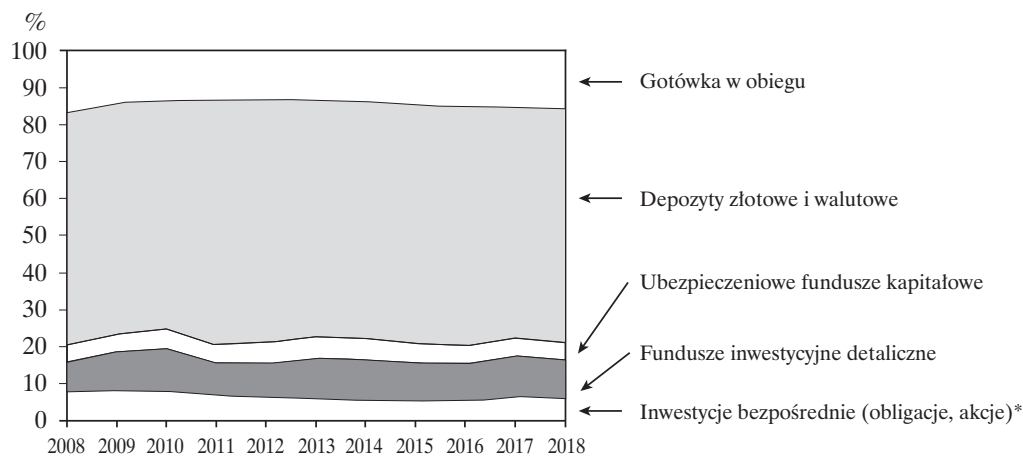

Źródło: https://www.analizyonline.com/pl; NBP, MF, GUS, IZFiA.

Na rysunku 4 pokazano wartość depozytów gospodarstw domowych zgromadzonych w bankach w porównaniu z funduszami inwestycyjnymi.

R y s u n e k. Aktywa gospodarstw domowych zgromadzone jako depozyty bankowe i jednostki uczestnictwa funduszy inwestycyjnych w latach 2008-2018 w mld PLN

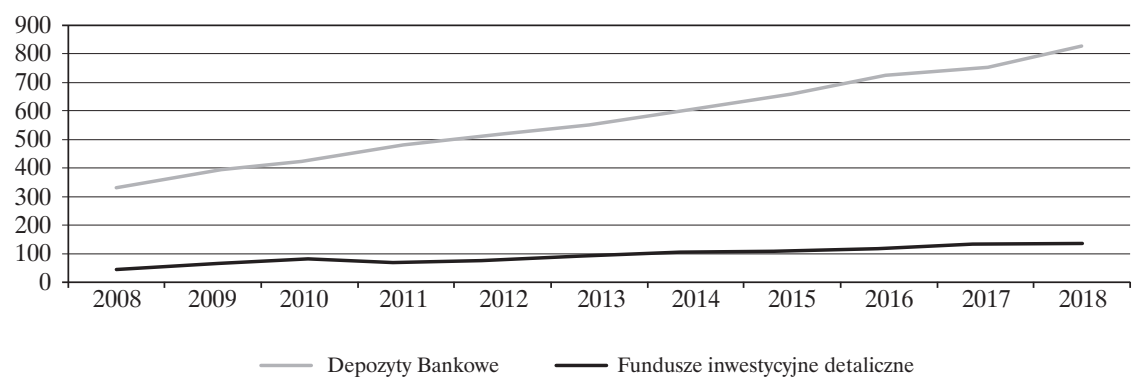

Źródło: opracowanie własne na podstawie danych: https://www.analizyonline.com/pl; NBP i IZFIA.

Przytoczone dane obrazują, że w ostatniej dekadzie szybko akumulowane były oszczędności finansowe. Niestety, problem polega na tym, że gromadzenie oszczędności odbywa się w grupie jedynie ok. $45 \%$ gospodarstw domowych. 
Rysunek 4 obrazuje również duży potencjał, jaki mają fundusze względem depozytów bankowych, jeżeli klienci będą skłonni konwertować część oszczędności z depozytów na fundusze inwestycyjne. W Unii Europejskiej aktywa w funduszach inwestycyjnych stanowią ok. $60 \%$ w relacji do aktywów zgromadzonych na depozytach bankowych, co wynika głównie z bardzo wysokiej wartości aktywów funduszy w relacji do depozytów w: Szwecji, Luksemburgu, Danii, Hiszpanii, na Węgrzech, we Włoszech i w Finlandia, gdzie wartość aktywów funduszy jest wyższa niż lokat.

Analizując poziom oszczędności gospodarstw domowych, należy rozpatrzeć ciekawe zagadnienie - jaki procent oszczędności ma cel długoterminowy i przewidywany do użycia po zakończeniu kariery zawodowej i przejścia na emeryturę. Na to pytanie nie można udzielić odpowiedzi wprost, chociaż może w tym pomóc badanie Diagnoza Społeczna, w którym zabezpieczenie na starość było wskazywanym celem gromadzenia oszczędności przez 23,6\% gospodarstw domowych.

\section{Fundusze inwestycyjne}

$\mathrm{Z}$ punktu widzenia klienta podstawowe znaczenie mają wyniki inwestycyjne funduszy, w które zainwestowane są oszczędności. Złożoność dyskusji na ten temat wynika ze skrajnie różnych strategii inwestycyjnych i związanego z tym różnego ryzyka inwestycyjnego. Coraz częściej klienci mogą korzystać z serwisów internetowych umożliwiających szybkie porównywanie funduszy, chociaż różne instytucje przyjmują nieco inne kryteria klasyfikowania funduszy. Izba Zarządzających Funduszami i Aktywami klasyfikuje 116 typów funduszy. W tabeli 3 podanych jest przykładowych 14 kategorii (z 22) publikowanych przez Analizy Online. Zaprezentowane dane dotyczą 3, 12, 36 i 60 miesięcy do grudnia 2018 r. włącznie. Pierwsze spostrzeżenie jest takie, że najwyższą stopę zwrotu w okresie 5 lat miały fundusze akcji amerykańskich $(23,4 \%)$, a najniższą fundusze akcji polskich $(-5,5 \%)$. W okresie 12 miesięcy 2018 r. powiększyła się liczba funduszy, które zanotowały straty. Na tym tle dobrze wypadają fundusze dłużne polskich papierów skarbowych. Ma to bezpośrednie przełożenie na nabycia, które od dwóch lat płyną w Polsce praktycznie tylko do funduszy obligacji i papierów skarbowych. 
Ta be la 3. Średnie stopy zwrotu z funduszy inwestycyjnych (grudzień 2018)

\begin{tabular}{|l|c|c|c|c|}
\hline \multicolumn{1}{|c|}{ Kategorie } & $\mathbf{3 ~ M}$ & $\mathbf{1 2} \mathbf{M}$ & $\mathbf{3 6} \mathbf{M}$ & $\mathbf{6 0 M}$ \\
\hline Akcji polskich małych i średnich spółek & $\mathbf{- 8 , 5 \%}$ & $\mathbf{- 1 9 , 7 \%}$ & $\mathbf{- 1 , 9 \%}$ & $\mathbf{- 3 , 9 \%}$ \\
\hline Akcji polskich & $\mathbf{- 5 , 7 \%}$ & $\mathbf{- 1 5 , 3 \%}$ & $4,8 \%$ & $\mathbf{- 5 , 5 \%}$ \\
\hline Akcji globalnych rynków rozwiniętych & $\mathbf{- 1 4 , 1 \%}$ & $\mathbf{- 1 2 , 6 \%}$ & $5,4 \%$ & $22,9 \%$ \\
\hline Akcji amerykańskich & $\mathbf{- 1 7 , 3 \%}$ & $\mathbf{- 1 0 , 8 \%}$ & $5,7 \%$ & $23,4 \%$ \\
\hline Akcji europejskich rynków rozwiniętych & $\mathbf{- 1 4 , 9 \%}$ & $\mathbf{- 1 4 , 8 \%}$ & $\mathbf{- 5 , 2 \%}$ & $6,6 \%$ \\
\hline Akcji azjatyckich bez Japonii & $\mathbf{- 7 , 2 \%}$ & $\mathbf{- 1 3 , 6 \%}$ & $9,5 \%$ & $20,3 \%$ \\
\hline Akcji globalnych rynków wschodzących & $\mathbf{- 6 , 8 \%}$ & $\mathbf{- 1 2 , 9 \%}$ & $9,6 \%$ & $\mathbf{- 1 , 8 \%}$ \\
\hline Mieszane zagraniczne zrównoważone & $\mathbf{- 6 , 3 \%}$ & $\mathbf{- 6 , 4 \%}$ & $4,0 \%$ & $16,5 \%$ \\
\hline Mieszane polskie zrównoważone & $\mathbf{- 3 , 3 \%}$ & $\mathbf{- 7 , 5 \%}$ & $7,6 \%$ & $1,1 \%$ \\
\hline Mieszane polskie stabilnego wzrostu & $\mathbf{- 1 , 7 \%}$ & $\mathbf{- 4 , 5 \%}$ & $3,4 \%$ & $3,9 \%$ \\
\hline Dłużne polskie papiery skarbowe & $1,3 \%$ & $2,2 \%$ & $4,9 \%$ & $12,9 \%$ \\
\hline Dłużne polskie korporacyjne & $0,1 \%$ & $0,6 \%$ & $6,0 \%$ & $10,8 \%$ \\
\hline Dłużne globalne uniwersalne & $\mathbf{- 0 , 3 \%}$ & $\mathbf{- 2 , 4 \%}$ & $4,10 \%$ & $12,7 \%$ \\
\hline Dłużne globalne korporacyjne & $0,1 \%$ & $0,6 \%$ & $6,0 \%$ & $10,8 \%$ \\
\hline
\end{tabular}

Źródło: https://www.analizyonline.com/pl, przykładowe 14 kategorii z 22 prezentowanych w serwisie.

Wyniki, tzw. performance funduszy zależny jest też od kosztów, które pobierają fundusze. Każdy fundusz musi publikować dane na temat pobieranych opłat i podawać Wskaźnik Kosztów Całkowitych (Total Expence Ratio (TER)). $\mathrm{Z}$ danych zbieranych przez Europejską Komisję Nadzoru (ESMA) wynika, że polskie fundusze w poszczególnych kategoriach inwestycyjnych pobierają wyższe opłaty niż fundusze na rynkach rozwiniętych (ESMA, 2017). Przykładowo, w Polsce fundusze akcyjne pobierają opłatę za zarządzanie ok. 4\%, fundusze mieszane 3,2\%, dłużne 1,5\% i pieniężne 0,9\%. Ministerstwo Finansów wprowadza ograniczenie opłat za zarządzanie. Według obliczeń Analiz Online, obniżka obejmie blisko 55\% detalicznych funduszy otwartych - głównie akcyjnych i mieszanych. Aby utrzymać ten sam poziom przychodów z tytułu opłaty za zarządzanie, aktywa funduszy detalicznych muszą wzrosnąć o ok. $+30 \%$ (do ok. 205 mld zł). Obniżka opłat w funduszach akcji i mieszanych spowoduje zmniejszenie zysków TFI, ale poprawi stopy zwrotu funduszy dla klientów.

Wprowadzenie Pracowniczych Planów Kapitałowych, w których maksymalna stawka opłaty za zarządzanie została ograniczona do $0,5 \%$ wymusi utworzenie nowych funduszy z wyraźnie niższymi opłatami za zarządzanie i wpłynie również na presję obniżania opłat w pozostałych funduszach.

Mała płynność polskiego rynku akcji i spadające ceny na GPW spowodowały, że szereg polskich funduszy coraz większą część aktywów inwestuje na rynkach zagranicznych. W przyszłości coraz więcej środków może być przenoszone do funduszy, które inwestują za granicą. 
Wspomnieć też należy o firmach zagranicznych, które dystrybuują swoje fundusze w Polsce na podstawie notyfikacji Komisji Nadzoru Finansowego. Ich aktywa są nadal niewielkie i wyniosły ok. 5 mld PLN na koniec grudnia 2018 roku. Taka sytuacja wynika z konkurencyjnej i szerokiej oferty „zagranicznej" funduszy polskich oraz łatwiejszego rozliczania podatków od zysków kapitałowych w funduszach zarejestrowanych w Polsce.

Udział poszczególnych TFI, zarządzających funduszami oferowanymi dla klientów detalicznych pokazany jest w tabeli 4. Największe pięć TFI ma łącznie 58\% udziałów w rynku. Rok 2018 przyniósł szereg zmian na rynku funduszy i TFI. Niestety, afera związana z misselingiem i obligacjami GetBack przyczyniła się do dużych odpływów z funduszy detalicznych TFI, które były zaangażowane w te papiery. Przełożyło się to również na odkupienia w innych funduszach, o łącznej wartości ok. $3 \mathrm{mld}$ zł, zwiększenie podaży różnych akcji i obligacji korporacyjnych na rynku i presję cenową na te papiery. Wiele publikacji poruszających ten temat negatywnie wpłynęło również na opinie dotyczące całego rynku kapitałowego w Polsce.

Ta b e l a 4. TFI zarządzające funduszami rynku kapitałowego i ich udział w rynku (grudzień 2018)

\begin{tabular}{|l|c|c|l|c|c|}
\hline \multicolumn{1}{|c|}{ Nazwa TFI } & $\begin{array}{c}\text { Aktywa } \\
\text { (mld zi) }\end{array}$ & $\begin{array}{c}\text { Udzial } \\
\text { w rynku }\end{array}$ & \multicolumn{1}{|c|}{ Nazwa TFI } & $\begin{array}{c}\text { Aktywa } \\
\text { (mld zt) }\end{array}$ & $\begin{array}{c}\text { Udzial } \\
\text { w rynku }\end{array}$ \\
\hline PKO TFI & 35,45 & $21,2 \%$ & MetLife TFI & 1,26 & $0,8 \%$ \\
\hline Pekao TFI & 19,40 & $11,6 \%$ & Opera TFI & 1,00 & $0,6 \%$ \\
\hline Santander TFI & 15,06 & $9,0 \%$ & AgioFunds TFI & 0,77 & $0,5 \%$ \\
\hline NN Investment Partners TFI & 14,00 & $8,4 \%$ & Trigon TFI & 0,74 & $0,4 \%$ \\
\hline Aviva Investors Poland TFI & 12,90 & $7,7 \%$ & Caspar TFI & 0,51 & $0,3 \%$ \\
\hline TFI PZU & 12,05 & $7,2 \%$ & INSIGNIS TFI & 0,35 & $0,2 \%$ \\
\hline Union Investment TFI & 11,98 & $7,2 \%$ & AGRO TFI & 0,31 & $0,2 \%$ \\
\hline Investors TFI & 7,30 & $4,4 \%$ & Superfund TFI & 0,31 & $0,2 \%$ \\
\hline Noble Funds TFI & 6,12 & $3,7 \%$ & Baltic Capital TFI & 0,29 & $0,2 \%$ \\
\hline Millennium TFI & 4,22 & $2,5 \%$ & Altus TFI & 0,28 & $0,2 \%$ \\
\hline Skarbiec TFI & 3,89 & $2,3 \%$ & Provide TFI & 0,24 & $0,1 \%$ \\
\hline Allianz TFI & 3,04 & $1,8 \%$ & Raiffeisen TFI & 0,23 & $0,1 \%$ \\
\hline ESALIENS TFI & 2,85 & $1,7 \%$ & Opoka TFI & 0,22 & $0,1 \%$ \\
\hline Rockbridge TFI & 2,84 & $1,7 \%$ & BPS TFI & 0,20 & $0,1 \%$ \\
\hline Quercus TFI & 2,52 & $1,5 \%$ & Eques Inv TFI & 0,07 & $0,0 \%$ \\
\hline AXA TFI & 1,89 & $1,1 \%$ & Capital Partners TFI & 0,06 & $0,0 \%$ \\
\hline BGŻ BNP Paribas TFI & 1,81 & $1,1 \%$ & CORUM TFI & 0,02 & $0,0 \%$ \\
\hline Ipopema TFI & 1,70 & $1,0 \%$ & Copernicus Capital & 0,01 & $0,0 \%$ \\
\hline Amundi TFI & 1,39 & $0,8 \%$ & & & \\
\hline Zról IZFIA & & & & \\
\hline
\end{tabular}

Źródło: IZFiA. 


\section{Dobrowolne oszczędzanie na emeryturę}

Dobrowolne oszczędności emerytalne gromadzone są w trzech formach prawnych:

- Pracowniczych Programach Emerytalnych (PPE),

- Indywidualnych Kontach Emerytalnych (IKE),

- Indywidualnych Kontach Zabezpieczenia Emerytalnego (IKZE).

Oszczędności zgromadzone w ramach PPE, działających od 1999 roku, wyniosły 12,8 mld zł i stanowiły jedynie $1 \%$ ogółu oszczędności finansowych gospodarstw domowych na koniec 2018 roku. Oszczędności zgromadzone w IKE wyniosły $8,2 \mathrm{mld}$ zł, a działające od stycznia $2012 \mathrm{r}$. IKZE zgromadziły 1,8 mld zł w 2018 roku. W sumie, dobrowolne programy emerytalne stanowily jedynie 1,9\% ogółu oszczędności gospodarstw domowych. Jest to bardzo mało i duże oczekiwania na poprawę sytuacji związane są z wprowadzeniem Pracowniczych Programów Kapitałowych, które mogą spowodować powszechność oszczędzania na emeryturę. Programy emerytalne wymagają promocji, dodatkowych zachęt, a w szczególności - edukacji (KNF, 2016).

Pracownicze Programy Emerytalne zgromadziły największe aktywa spośród produktów dobrowolnego oszczędzania. Potwierdza to tezę, że organizowane i sponsorowane przez pracodawcę oszczędności są najatrakcyjniejszą formą oszczędzania dla przyszłych emerytów. Oprócz tego, ważna jest wygoda, niższe koszty obsługi i niskie prowizje pobierane przez instytucje finansowe. W tabeli 5 pokazana jest wartość środków zgromadzonych w PPE w poszczególnych formach prawnych:

a) umowa o wnoszenie przez pracodawcę składek do funduszu inwestycyjnego,

b) pracowniczego funduszu emerytalnego,

c) umowa grupowego ubezpieczenia na życie pracowników z zakładem ubezpieczeń $\mathrm{w}$ formie grupowego ubezpieczenia na życie $\mathrm{z}$ ubezpieczeniowym funduszem kapitałowym.

$\mathrm{Na}$ koniec 2018 roku funkcjonowało $1230 \mathrm{PPE}$, prowadzonych przez 1389 pracodawców, w których zarejestrowano łącznie 426,0 tysięcy uczestników, przy czym uczestników czynnych było 334,3 tys. Niestety, rynek pracowniczych programów emerytalnych rozwijał się wolno i objął niewielką liczbę osób aktywnych zawodowo (ok. 2,6\%). 
Ta b e l a 5. Liczba uczestników i wartość aktywów PPE, dane na grudzień 2018 roku

\begin{tabular}{|l|c|c|c|c|}
\hline \multicolumn{1}{|c|}{ Forma programu } & $\begin{array}{c}\text { Liczba } \\
\text { kont czynnych } \\
\text { (tys.) }\end{array}$ & $\begin{array}{c}\text { Liczba } \\
\text { kont biernych } \\
\text { (tys.) }\end{array}$ & $\begin{array}{c}\text { Liczba } \\
\text { kont razem } \\
\text { (tys.) }\end{array}$ & $\begin{array}{c}\text { Wartość } \\
\text { (mld zt) }\end{array}$ \\
\hline Fundusze inwestycyjne & 229,6 & 55,1 & 284,7 & 7,7 \\
\hline Pracownicze fundusze emerytalne & 16,0 & 17,3 & 33,3 & 1,8 \\
\hline Zakłady ubezpieczeń na życie & 88,7 & 19,3 & 108 & 3,3 \\
\hline Razem & $\mathbf{3 3 4 , 3}$ & $\mathbf{9 1 , 7}$ & $\mathbf{4 2 6}$ & $\mathbf{1 2 , 8}$ \\
\hline
\end{tabular}

Źródło: KNF, 2019a

Największe aktywa, tj. 60\%, zgromadzone są w PPE prowadzonym poprzez fundusze inwestycyjne, mają one również najwięcej członków. Najwyższe średnie aktywa w przeliczeniu na jednego członka uzyskały pracownicze fundusze emerytalne. Na koniec 2018 r. ok. 78\% osób objętych dobrowolnym zabezpieczeniem emerytalnym w ramach PPE stanowili uczestnicy czynni, na rzecz których pracodawca odprowadził składki podstawowe.

Indywidualne Konta Emerytalne wprowadzono w 2004 roku, ale nie osiągnęły popularności. W roku 2008 podwyższono kwoty limitu wpłat na IKE do trzykrotności przeciętnego prognozowanego wynagrodzenia miesięcznego w gospodarce narodowej na dany rok. Liczba osób, które posiadały konta IKE w na koniec 2018 r. wyniosła 995,7 tys. Na koniec 2018 r. IKE prowadzone były przez: 57 instytucji finansowych: 14 zakładów ubezpieczeń na życie, 18 towarzystw funduszy inwestycyjnych, 7 domów maklerskich, 13 banków i 5 powszechne towarzystwa emerytalne.

Ta b e l a 6. Liczba uczestników i wartość aktywów IKE, dane na grudzień 2018 roku

\begin{tabular}{|l|c|c|}
\hline \multicolumn{1}{|c|}{ Forma programu } & Liczba kont (tys.) & Wartość (mld zt) \\
\hline Zakłady ubezpieczeń & 562,5 & 2,6 \\
\hline Fundusze inwestycyjne & 316,8 & 2,7 \\
\hline Domy maklerskie & 32,5 & 1,4 \\
\hline Bbanki & 78,2 & 1,8 \\
\hline Dobrowolne fundusze emerytalne & 5,3 & 0,06 \\
\hline Ogółem & $\mathbf{9 9 5 , 7}$ & $\mathbf{8 , 7}$ \\
\hline
\end{tabular}

Źródło: KNF, Raport IKE oraz IKZE w 2018 r. 
Indywidualne Konta Zabezpieczenia Emerytalnego wprowadzono 1 stycznia 2012 roku w celu poszerzenia oferty i uatrakcyjnienia programów emerytalnych pod względem podatkowym. W grudniu $2018 \mathrm{r}$. mieliśmy 730,4 tys. kont IKZE. Szybko rosnąca liczba kont IKZE w stosunku do kont IKE świadczy o silnym czynniku motywującym, jakim jest możliwość odliczenia wpłaty od podatku dochodowego. Od stycznia 2014 roku wprowadzono również zapis, że od wypłaty z IKZE pobierany będzie w przyszłości podatek w zryczałtowanej formie $10 \%$ dochodu, co jest istotnym uatrakcyjnieniem, ponieważ wcześniej przewidywano opodatkowanie wypłat na zasadach ogólnych.

Ta b e l a 7. Liczba uczestników i wartość aktywów IKZE, dane na grudzień 2018 roku

\begin{tabular}{|l|c|c|}
\hline \multicolumn{1}{|c|}{ Forma programu } & Liczba kont (tys.) & Wartość (mIn zi) \\
\hline Zakłady ubezpieczeń & 447,3 & 635,1 \\
\hline Fundusze inwestycyjne & 150,2 & 1083 \\
\hline Domy maklerskie & 11,1 & 119,3 \\
\hline Banki & 20,3 & 156,2 \\
\hline PTE, dobrowolne fundusze emerytalne & 101,3 & 320,8 \\
\hline Ogółem & 730,4 & 2314,9 \\
\hline
\end{tabular}

Źródło: KNF, Raport IKE oraz IKZE w 2018 r.

Działania na rzecz rozwoju III filara nie spotkały się z dużym zainteresowaniem społeczeństwa. Tylko 4,3\% liczby osób pracujących ma konto IKZE oraz 5,8\% liczby osób ma konto IKE. Główne przyczyny małego rozwoju PPE i IKE upatrywane były w braku ulgi w podatku dochodowym (od wpłacanej składki) przy oszczędzaniu w tych formach. Zwolnienie z podatku od zysków kapitałowych stanowi odroczoną w czasie i zbyt małą zachętę. Do kolejnych przyczyn małego zainteresowania można też zaliczyć przepisy utrudniające tworzenie i obsługę programów emerytalnych. Istnieje również potrzeba uelastycznienia dysponowania wkładem (oszczędnościami) z zachowaniem celu emerytalnego w zależności od różnych okoliczności życiowych. Pracownicze Programy Kapitałowe mają rozwiązania, które spełniają ww. wymogi.

Przyczynami małej popularności gromadzenia oszczędności długoterminowych i emerytalnych są m.in.:

- niskie dochody bieżące przeważającej liczby gospodarstw domowych przekładają się na brak możliwości generowania i lokowania nadwyżek finansowych z przeznaczeniem na przyszłą konsumpcję po osiągnięciu wieku emerytalnego; 
- część gospodarstw domowych nie wykazuje skłonności do długoterminowego oszczędzania;

- brak jest świadomości niskiej stopy zastąpienia, czyli niskiej wartości przyszłej emerytury z obowiązkowego systemu w stosunku do ostatnich wynagrodzeń;

- część społeczeństwa jest przekonana, że państwo jest odpowiedzialne za świadczenia emerytalne i zatroszczy się o dochody przyszłych emerytów;

- negatywna kampania prowadzona przy okazji ograniczania działalności otwartych funduszy emerytalnych, która spowodowała niechęć klientów do instytucji finansowych lokujących oszczędności klientów na rynku kapitałowym;

- nierozstrzygnięta kwestia dalszego funkcjonowania OFE i trudne do przewidzenia skutki ewentualnej „nacjonalizacji” aktywów posiadanych przez OFE.

\section{Perspektywy rozwoju funduszy inwestycyjnych}

Można spodziewać się, że aktywa funduszy inwestycyjnych będą w kolejnych latach przyrastały w szybszym tempie niż lokaty bankowe ze względu na wprowadzenie Pracowniczych Programów Kapitałowych. Prawdopodobnie klienci będą również poszukiwać możliwości inwestowania oszczędności w alternatywny sposób, a nie tylko na nisko oprocentowanych lokatach bankowych. Część oszczędności gospodarstw domowych, z rachunków bankowych i depozytów wynoszących 828 mld zł może być konwertowana na fundusze inwestycyjne. Tempo takich konwersji nie będzie duże ze względu na ostrożne inwestowanie $\mathrm{w}$ fundusze $\mathrm{i}$ będzie zależało $\mathrm{w}$ dużym stopniu od koniunktury na rynkach kapitałowych oraz zysków (lub strat), jakie będą generowały fundusze. Zawirowania na rynku i straty funduszy akcyjnych i zrównoważonych w czasie bessy zniechęcają na dłuższy czas klientów indywidualnych do oszczędzania w funduszach o wyższym ryzyku.

Bogacenie się społeczeństwa jest kluczowym czynnikiem przyszłego rozwoju funduszy inwestycyjnych. Wraz ze wzrostem gospodarczym zwiększa się popularność inwestowania w fundusze inwestycyjne w krajach rozwiniętych. Upowszechnienie dobrowolnych produktów emerytalnych jest niewielkie i aktywa na poziomie zaledwie 1\% PKB w porównaniu do 15-20\% PKB w krajach OECD. Wzrost aktywów i rozwój produktów emerytalnych przyśpieszy w kolejnych latach. Rynek kapitałowy jest bardzo ważnym elementem gospodarki, bez którego niemożliwe jest tworzenie przewag innowacyjnych i konkurencyjnych. Tym bardziej należy czuwać nad jego zrównoważonym rozwojem. 
Perspektywy dla sektora funduszy inwestycyjnych są optymistyczne, niemniej jednak pamiętać należy, że tempo wzrostu aktywów funduszy będzie zależało od:

- zmiany sposobów gospodarowania wolnymi środkami przez gospodarstwa domowe i elastycznego dywersyfikowania oszczędności na depozytach bankowych i w funduszach inwestycyjnych;

- koniunktury na rynkach kapitałowych;

- awersji do ryzyka polskich inwestorów;

- niskich stóp procentowych sprzyjających poszukiwaniu wyższych stóp zwrotu;

- bogacenia się społeczeństwa i akumulacji kapitału;

- postępującej edukacji finansowej społeczeństwa;

- poszerzania oferty o fundusze operujące na rynkach zagranicznych;

- większej przejrzystości finansowej firm zarządzających aktywami;

- zmniejszających się prowizji i opłat za zarządzanie pobieranych przez fundusze;

- zwiększenia zaufania do funduszy inwestycyjnych poprzez odpowiednie wyjaśnianie klientom ryzyka związanego $\mathrm{z}$ inwestowaniem $\mathrm{w}$ fundusze i zmienności wyników różnych typów funduszy;

- rozwoju dobrowolnych planów emerytalnych IKE, IKZE, PPE i PPK;

- szczegółowe prezentowanie kosztów pobieranych przez dystrybutora i fundusz;

- regulacji prawnych mających na celu poprawienie przejrzystości oferty dla klientów, w tym badanie i ocena odpowiedniości funduszu dla danego klienta.

W celu stymulowania różnych form oszczędzania emerytalnego w funduszach należy:

- uświadamiać społeczeństwo o potrzebie zwiększania oszczędności;

- szerzej edukować i informować klientów nt. możliwości nabywania jednostek funduszy w ramach tańszych produktów emerytalnych;

- wyjaśniać w kanałach sprzedaży możliwości inwestowania w fundusze obligacji skarbu państwa jako alternatywy dla lokat bankowych;

- zachęcać do dywersyfikacji oszczędności, w tym nabywania różnych funduszy o różnych strategiach inwestycyjnych;

- propagować elektroniczne kanały dystrybucji;

- wprowadzać bardziej nowoczesne procedury bazujące na elektronicznych dokumentach i elektronicznych kanałach dystrybucji. 


\section{Bibliografia}

Biuro Pełnomocnika Rządu ds. Reformy Zabezpieczenia Społecznego. (1997). Bezpieczeństwo dzięki różnorodności. Reforma systemu emerytalno-rentowego w Polsce (wersja druga poprawiona). Warszawa, luty.

Christensen D. (1995). Survising the coming mutual fund crisis. Massachusetts: Little Brown \& Co.

Czapiński, J. i Panek, T. (2015). Diagnoza Spoteczna 2015. Warunki i jakość życia Polaków. Warszawa: Rada Monitoringu Społecznego.

ESMA. (2017). Raport The impact of charges on mutual fund returns. Report on Trends, 6 listopad. Risks and Vulnerabilities, 2.

Henriques, D. (1997). Fidelity's World: The Secret Life and Public Power of the Mutual Fund Giant. New York: Touchstone.

IZFiA i SpotData. (2019). Raport roczny 2018. Warszawa: Izba Zarządzających Funduszami i Aktywami.

IZFiA. (2018). Aktywa funduszy inwestycyjnych (grudzień 2018). Pozyskano z https:// www.analizy.pl/fundusze/wiadomosci/24766/aktywa-funduszy-inwestycyjnych-\%28grudzien-2018\%29.html; www.analizy.pl.

IZFiA. (2018a). Raport roczny 2017. Warszawa: Izba Zarządzających Funduszami i Aktywami.

KNF. (2016). Sektor funduszy emerytalnych w Polsce - ewolucja, ksztatt, perspektywy. Warszawa: Urząd Komisji Nadzoru Finansowego.

KNF. (2019). Indywidualne konta emerytalne oraz Indywidualne Konta Zabezpieczenia Emerytalnego w 2018 roku. Warszawa: Urząd Komisji Nadzoru Finansowego.

KNF. (2019a). Pracownicze Programy Emerytalne w 2018 roku. Warszawa: Urząd Komisji Nadzoru Finansowego.

Lavine, A. (1997). Wszystko o funduszach powierniczych. Warszawa: WIG Press.

Meluch, B, Nietrzepka, E. i Orlik, T. (1993). Fundusze powiernicze - zbiorowy inwestor na rynku kapitałowym. Warszawa: Twigger.

MF. (2019). Strategia Rozwoju rynku kapitałowego. Projekt 28 lutego 2019. Warszawa: Ministerstwo Finansów.

Miziołek, T. i Trzbiński, A. (2018). Rynek funduszy inwestycyjnych w Polce. Warszawa: Difin.

NBP. (2019). Statystyka funduszy inwestycyjnych 2018. Warszawa: Narodowy Bank Polski. Pozyskano z https://www.nbp.pl/home.aspx?f=/statystyka/pieniezna_i_bankowa/sfi.html.

Orlik, T. (2015). Udział funduszy inwestycyjnych w oszczędnościach gospodarstw domowych w latach 2004-2014. W: M. Kawiński (red.), Doubezpieczenie społeczne idea i kontynuacja. Warszawa: Oficyna wydawnicza SGH.

Rutecka, J. (2011). Zakres redystrybucji dochodowej w ubezpieczeniowym systemie emerytalnym. Warszawa: Oficyna wydawnicza SGH.

Szumlicz, T., Alińska, A. i Pietrzak, B. (red). (2011). Finansowanie systemu zabezpieczenia emerytalnego w świetle kryzysu ekonomicznego. W: A. Alińska, B. Pietrzak (red.), Finanse publiczne a kryzys ekonomiczny. Warszawa: CeDeWu.

Szumlicz, T., Walkowiak, W., Wasilewska-Trenkner, H., Czapiński, J., Sankowski, J. i Herbich M. (2010). III Filar recepta na wyższa emeryturę. Pozyskano z https://piu.org.pl/public/ upload/ibrowser/Emerytalne-1n.pdf.

Ustawa z dnia 20 kwietnia 2004 r. o indywidualnych kontach emerytalnych (DzU Nr 116, poz. 1205 , z późn. zm.). 
Ustawa z dnia 20 kwietnia 2004 r. o pracowniczych programach emerytalnych (DzU 2016.0.1449, z późn. zm.).

Ustawa z dnia 28 sierpnia 1997 r. o organizacji i funkcjonowaniu funduszy emerytalnych (t.j. DzU $2010 \mathrm{Nr}$ 34, poz. 189, z późn. zm.).

Ustawa z dnia 4 października 2018 r. o pracowniczych planach kapitałowych (DzU 2018, poz. 2215, z późn. zm.).

www.analizy.pl. Struktura oszczędności gospodarstw domowych 2008, 2009, 2010, 2011, 2012, 2013, 2014, 2015, 2016, 2017, 2018.

www.nbp.pl/home.aspx?f=/statystyka/pieniezna_i_bankowa/sfi.html 


\title{
Rozdział 7
}

\author{
KAMIL GEMRA*, JANUSZ MARUSZEWSKI**
}

\section{Inwestorzy indywidualni wobec relacji inwestorskich emitentów obligacji}

Artykuł poświęcono kwestii oczekiwań inwestorów indywidualnych wobec komunikacji prowadzonej przez emitentów publicznych emisji obligacji. Na podstawie badania kwestionariuszowego z pytaniami zamkniętymi, na grupie 554 inwestorów, zbadano zgodnie z postawionym celem ich potrzeby oraz zachowania w kontekście prowadzonych relacji inwestorskich. Wyniki pokazały, że głównym źródłem informacji dla inwestorów jest prospekt emisyjny lub memorandum informacyjne. Oczekują oni zabezpieczenia w formie hipoteki. Najważniejszym czynnikiem decydującym o inwestycji jest oprocentowanie, a także czynniki, na które wpływa komunikacja emitentów, czyli historia spółki oraz wiarygodność zarządu. Nie ma natomiast zależności pomiędzy wysokością oprocentowania a tym, jak wnikliwie inwestor czyta prospekt emisyjny.

Słowa kluczowe: relacje inwestorskie, obligacje, Catalyst.

\section{Individual Investors Versus Investor Relations of Bond Issuers}

The article shows expectations of individual investors regarding communication between them and issuers of public bonds. Survey conducted on a group of 554 respondents was based on questionnaire with closed questions and examined their needs and behaviors. The findings revealed prospectus and information memorandum as the main sources of knowledge. In terms of their needs, investors mostly expect mortgage collateral. Significant factors influencing investment decisions are rate of interest and factors strictly connected with investor relation - company's

\footnotetext{
* dr Kamil Gemra - Szkoła Główna Handlowa, aleja Niepodległości 162, 02-554 Warszawa, Polska; https://orcid.org/0000-0001-5292-2363

** $\quad$ mgr inż. Janusz Maruszewski - JPP GROUP SP. Z O.O., ul. Ratuszowa 11, 03-450 Warszawa, Polska.
} 
history and management board's credibility. However, there is no relationship between rates of interest and how thoroughly the investor reads the prospectus.

Keywords: investor relations, bonds, Catalyst.

JEL: G10

\section{Wprowadzenie}

Obligacje korporacyjne w ostatnich miesiącach weszły na łamy pierwszych stron gazet. Przez niewypłacalność czołowej firmy windykacyjnej w kraju instrumentem zaczęli interesować się dziennikarze, a także inwestorzy dotąd niezwracający na niego uwagi. Jednocześnie we wrześniu 2018 r. zorganizowany rynek obrotu obligacjami Catalyst, prowadzony przez GPW, obchodził swoją dziewiątą rocznicę. W tym czasie wpisał się $\mathrm{w}$ architekturę rynku finansowego w Polsce i z jednej strony stał się platformą do pozyskiwania finansowania przez przedsiębiorstwa, z drugiej zaś - umożliwił inwestorom indywidualnym łatwy dostęp do lokowania swoich nadwyżek finansowych w obligacje. Prężnie rozwijał się również rynek pierwotny, gdzie część emisji prowadzona była w formule publicznych emisji obligacji zarówno w oparciu o prospekt emisyjny zatwierdzany w Komisji Nadzoru Finansowego, jak i mniejsze emisje publiczne o wartości do 2,5 mln euro oparte na memorandum. Jedną z głównych cech tak prowadzonych emisji jest możliwość dotarcia do nieograniczonego grona inwestorów poprzez odpowiednią komunikację skierowaną do potencjalnych zainteresowanych.

Właśnie prowadzone relacje inwestorskie przez emitentów obligacji w publicznych emisjach skłoniły autorów do przeprowadzenia badania i napisania niniejszego artykułu. Celem artykułu jest poznanie oraz sklasyfikowanie potrzeb i zachowań inwestorów w kontekście relacji inwestorskich prowadzonych przez emitentów obligacji w publicznych emisjach. Ponadto, aby osiaggnąć założony cel zdecydowano się na postawienie następujących pomocniczych pytań badawczych:

- co jest głównym źródłem informacji dla inwestora o danym emitencie;

- jakiego zabezpieczenia obligacji oczekują inwestorzy przy publicznych emisjach;

- jakie czynniki decydują o zainwestowaniu w daną emisję obligacji korporacyjnych;

- jak oprocentowanie obligacji wpływa na skłonność inwestorów do zapoznania się $\mathrm{z}$ informacjami o emitencie? 
W artykule zdecydowano się na postawienie następujących hipotez badawczych:

1. Prospekt emisyjny lub memorandum nie są podstawowym źródłem informacji dla inwestorów.

2. Inwestorzy najchętniej oczekują zabezpieczenia obligacji hipoteką.

3. Najważniejszym czynnikiem decydującym o inwestycji jest oprocentowanie obligacji.

4. Inwestorzy obejmujący obligacje z wyższym oprocentowaniem w mniejszym stopniu zapoznają się z prospektem emisyjnym lub memorandum informacyjnym.

Osiągnięcie założonego celu, odpowiedzi na pytania badawcze oraz weryfikacja postawionych hipotez będzie możliwa poprzez analizę wyników z przeprowadzonego w dniach 1 lipca - 31 sierpnia 2018 r. badania kwestionariuszowego z pytaniami zamkniętymi na próbie celowej inwestorów indywidualnych liczącej 554 osoby.

\section{Znaczenie $\mathrm{i}$ istota relacji inwestorskich}

Jednym z ważniejszych zagadnień w procesie budowy i funkcjonowania nowoczesnego, a zarazem konkurencyjnego rynku finansowego, są relacje $\mathrm{z}$ inwestorami. Stanowią one proces komunikacji z obecnymi i przyszłymi inwestorami, a także są głównym narzędziem wykorzystywanym przez spółki do budowania zaufania wśród uczestników rynku. Świadome kształtowanie investor relations (IR) zwiększa szanse sukcesu na rynku finansowym, umożliwiając inwestorom osiągnięcie oczekiwanego zwrotu z kapitału. Relacje inwestorskie to nie tylko komunikacja $\mathrm{z}$ otoczeniem i utrzymanie pożądanego wizerunku, lecz także kształtowanie tego wizerunku wśród inwestorów, zarządzanie przepływem informacji z zakresu finansów, marketingu i strategii pomiędzy spółką giełdową a społecznością inwestorską (Krug, 2008, s. 267). Niezawodna, pewna informacja jest istotna dla rynku kapitałowego, ponieważ bieżące ceny papierów wartościowych wynikają z estymacji oczekiwań przyszłych dochodów. Im bardziej informacja jest kompletna i rzetelna dla inwestorów, tym mniejsze jest ryzyko błędnego oszacowania przyszłych przepływów pieniężnych (Rawicki, 2012, s. 48).

Relacje inwestorskie zaczęto kształtować w USA niejako na skutek wprowadzenia ustaw: w 1933 r. o papierach wartościowych oraz w 1934 r. o obrocie papierami wartościowymi, by chronić amerykańskie społeczeństwo przed nadużyciami w emisji i obrocie walorami giełdowymi. Zakres tego pojęcia zasadniczo się później rozszerzył, a analitycy zaczęli więcej uwagi przywiązywać do 
rzetelności wiedzy uzyskiwanej od osób kształtujących wizerunek finansowy niż do ogólnej sytuacji na rynku (Rawicki, 2011, s. 69). W Polsce nadal jest to dziedzina młoda, mimo iż pierwszy departament odpowiedzialny za kontakty z inwestorami powstał w 1993 r., dwa lata po rozpoczęciu działalności przez warszawską Giełdę Papierów Wartościowych. Od tego czasu zainteresowanie polskim rynkiem kapitałowym zwiększało się, co spowodowało powstawanie większej liczby departamentów IR oraz profesjonalizację wykonywanych przez nich działań (Olędzki i Tworzyło, 2006, s. 265).

Relacje inwestorskie (investor relations - IR) zgodnie z nazwą koncentrują się na relacji firmy z inwestorami, wśród których ważną rolę odgrywają akcjonariusze - współwłaściciele spółki. Natomiast nie jest to jedyna grupa. $\mathrm{Na}$ znaczeniu, również w Polsce, zyskują też inwestorzy, którzy nabywają instrumenty dłużne poszczególnych spółek (Dziawgo, 2011, s. 15). Dostęp do aktualnej i wiarygodnej informacji zwiększa zaufanie i bezpieczeństwo inwestorów, przyciąga inwestorów długoterminowych, eliminuje niepewność towarzyszącą inwestycjom na rynku, a tym samym pozwala obniżyć koszty kapitału (Łukasik, 2014, s. 111). Kompleksowy program działań proinwestorskich ma za zadanie kształtować opis firmy przez pryzmat wzbudzania nadziei inwestorów na przyszłe zyski czy też na program korzyści dla inwestorów i akcjonariuszy (Szamańska, 2005, s. 304).

Relacje inwestorskie mogą być prowadzone w dwóch modelach. Model tradycyjny relacji inwestorskich zakłada wypełnianie obowiązków informacyjnych wynikających z przepisów prawa. Dzięki temu spółka ogranicza ryzyko regulacyjne, unika kar za nieprzestrzeganie prawa i chroni się przed niechęcią inwestorów do spółek zaniedbujących obowiązki informacyjne. Model nowoczesny wykracza poza regulacyjny obszar IR, kładąc silny nacisk na aktywną komunikację z rynkiem.

Wobec zmian zachodzących w gospodarce relacje inwestorskie przestają być tylko instrumentem raportowania wartości, lecz same zaczynają być ważnym jej generatorem (Szablewski i Panfil, 2006, s. 596). Właśnie z tego względu, aby lepiej rozumieć, jak tę wartość dla inwestorów generować, na jakie aspekty prowadzenia relacji inwestorskich zwracać uwagę, zdecydowano się przeprowadzić opisane w niniejszym artykule badanie. 


\section{Przebieg badania}

Badanie zostało przeprowadzone dwuetapowo. Na pierwszym etapie, który rozpoczął się w czerwcu 2018 r. i trwał dwa tygodnie, wśród 15 osób został przeprowadzony pilotaż. Jego celem było dopracowanie kwestionariusza ankiety i uzyskanie wstępnych informacji, pozwalających na doprecyzowanie celów badania. W pilotażu brali udział przede wszystkim inwestorzy oraz osoby znające specyfikę publicznych emisji obligacji.

Badanie właściwe odbywało się od 1 lipca do 30 sierpnia 2018 roku. Osobami uczestniczącymi w badaniu byli czytelnicy serwisu Strefa Inwestorów - inwestorzy indywidualni, zainteresowani przede wszystkim inwestowaniem w akcje, ale też interesujący się obligacjami. Łącznie, kwestionariusz ankiety wypełniło 554 uczestników. Udział w badaniu był dobrowolny i anonimowy. Uczestnicy badania byli o nim informowani w serwisie Strefa Inwestorów, w formie informacji dołączonej do artykułów oraz za pośrednictwem wiadomości e-mail. Informacja o badaniu była także rozsyłana za pośrednictwem mediów społecznościowych, m.in. Facebook, LinkedIn i Twitter. Realizacja założonego celu badania wymagała podzielenia uczestników na dwie grupy. Odbyło się to za pomocą pytania filtrującego dotyczącego dotychczasowego inwestowania w obligacje. Osoby, które zadeklarowały, że do tej pory nie inwestowały w obligacje, nie wypełniały dalszej części kwestionariusza. We właściwej części badania udział wzięły jedynie osoby, które zadeklarowały, że inwestowały w obligacje. W odpowiedzi na pytanie „czy inwestowałeś do tej pory w obligacje korporacyjne?" 261 uczestników badania zadeklarowało, że już to robiło. Te osoby odpowiadały na 12 kolejnych pytań i to oni w niniejszym artykule będą określani jako uczestnicy badania.

Osoby, które wzięły udział w badaniu na końcu odpowiadały na pytania metryczkowe. Poniżej zaprezentowano najważniejsze informacje charakteryzujące uczestników badania, pozwalające poznać profil inwestorów, biorących udział w publicznych emisjach obligacji.

Zdecydowana większość uczestników badania $(43,2 \%)$ w pytaniu o staż inwestorski („od jak dawna inwestujesz?”) zadeklarowała, że robi to od ponad 10 lat. Druga, najliczniejsza grupa badanych $(32,5 \%)$ zadeklarowała, że zajmuje się inwestowaniem od 5 do 10 lat. Można więc stwierdzić, że ponad 75\% osób badanych to inwestorzy ze stażem co najmniej 5-letnim. 
Ry s u n e 1. Rozkład odpowiedzi na pytanie: od jak dawna inwestujesz? ( $\mathrm{N}=261$, pytanie jednokrotnego wyboru)

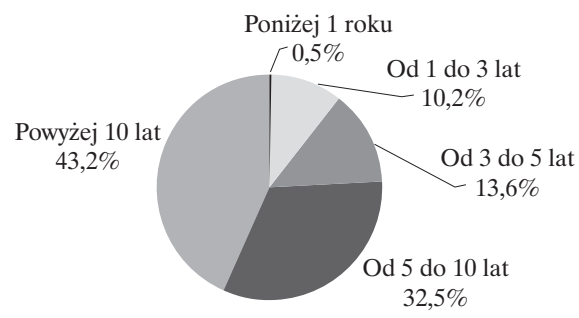

Źródło: opracowanie własne.

Co równie istotne z punktu widzenia badania, aż 53,7\% uczestników zadeklarowało, że inwestuje w całości samodzielnie (odpowiadając na pytanie „w jaki sposób inwestujesz?”). Ta liczba jest ważna, ponieważ to właśnie te osoby są głównymi odbiorcami relacji inwestorskich, prowadzonych przez spółki oferujące obligacje w ramach publicznych emisji.

Ry s u n e k 2. Rozkład odpowiedzi na pytanie: w jaki sposób inwestujesz?

( $N$ = 261 pytanie jednokrotnego wyboru)

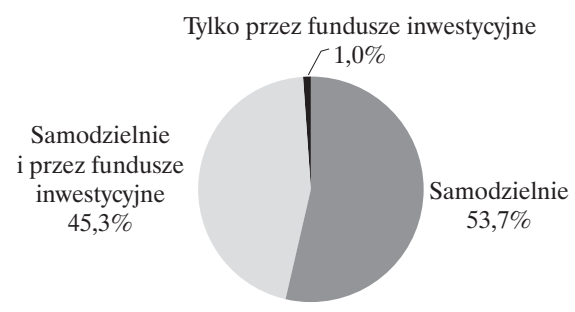

Źródło: opracowanie własne.

W kolejnym pytaniu, dotyczącym wartości portfela inwestycyjnego (,jaka jest wartość Twojego całego portfela inwestycyjnego?"), 37\% badanych zadeklarowało odpowiedź „od 100 do 500 tys. zł”. Druga najliczniej reprezentowana grupa $(25,1 \%)$ zadeklarowało wartość portfela inwestycyjnego na poziomie „od 50 do 100 tys. zł”. Oznacza to, że ponad 60\% uczestników badania to inwestorzy z istotnym portfelem inwestycyjnym z punktu widzenia emitentów obligacji, bo o wartości co najmniej 50 tys. zł. 
Ry s u n e 3 . Rozkład odpowiedzi na pytanie: jaka jest wartość Twojego całego portfela inwestycyjnego? ( $N=261$ pytanie jednokrotnego wyboru)

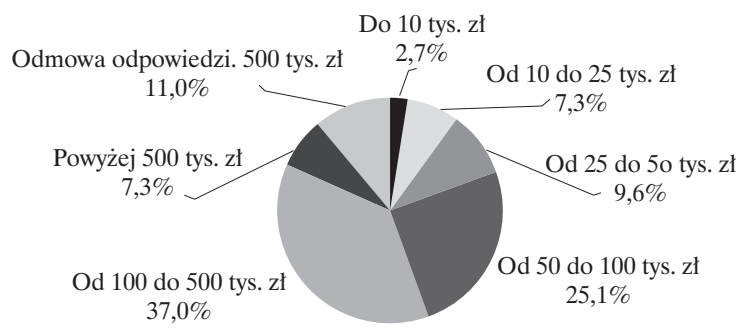

Źródło: opracowanie własne.

Ponadto w badaniu sprawdzono wykształcenie inwestorów. Są to osoby z wyższym wykształceniem - taką deklarację złożyło $79 \%$ uczestników. Zdecydowana większość $(77,6 \%)$ to osoby pracujące, a w następnej kolejności $(13,7 \%)$ emeryci. Tylko $2 \%$ uczestników zadeklarowało status studenta. Warto również zwrócić uwagę na fakt, że aż $96 \%$ uczestników badania to mężczyźni, a jedynie $4 \%$ to kobiety.

W badaniu sprawdzono również w jakiego rodzaju emisje inwestowali do tej pory jego uczestnicy. Zdecydowana większość badanych (ponad 70\%) zadeklarowała udział w publicznych emisjach obligacji na podstawie prospektu emisyjnego. Drugą najpopularniejszą formą inwestowania w ramach emisji obligacji są oferty prywatne (wybrane przez $42 \%$ badanych). Jedynie ok. 1/4 uczestników badania $(26,82 \%)$ zadeklarowało udział w publicznych emisjach obligacji na podstawie memorandum.

Ry s u n e k 4. Rozkład odpowiedzi na pytanie: w jakie emisje obligacji korporacyjnych inwestowateś do tej pory? ( $\mathrm{N}=261$ pytanie wielokrotnego wyboru)

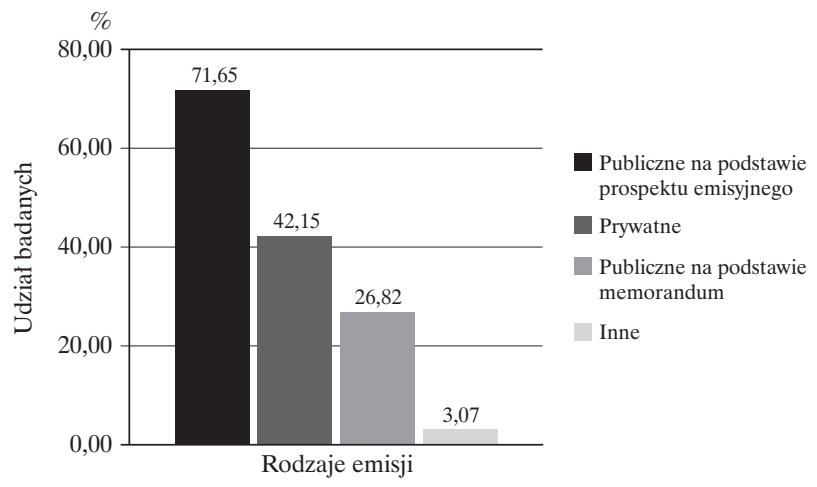

Źródło: opracowanie własne. 
Co istotne z punktu widzenia wyciągania ewentualnych wniosków z wyników badania, poproszono również jego uczestników o deklarację, jakie kwoty inwestowali do tej pory w emisje obligacji. Najwięcej uczestników badania $(36,4 \%)$ wskazało, że inwestuje kwoty w przedziale $10000-50000$ tys. zł. Kolejną liczną grupą $(21,5 \%)$ były osoby deklarujące inwestowanie pomiędzy 5000 a 10000 tys. zł. Trzecią najliczniejszą grupę stanowili inwestorzy, angażujący środki pieniężne pomiędzy 50000 a 100000 zł. Liczona dla tej odpowiedzi średnia z przedstawionych przedziałów (przy założeniu środkowej wartości ostatniego przedziału na poziomie $150000 \mathrm{zl}$ ) wynosi ok. $34200 \mathrm{zł}$.

Ry s u n e k 5ozkład odpowiedzi na pytanie: jakie kwoty inwestujesz lub inwestowałeś w pojedynczą emisję obligacji korporacyjnych?

( $N=261$, pytanie jednokrotnego wyboru)

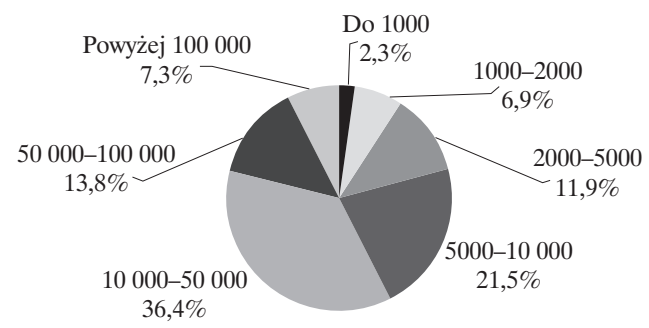

Źródło: opracowanie własne.

\section{Weryfikacja hipotez w obliczu realizacji badania}

W artykule postawiono cztery pomocnicze pytania badawcze i hipotezy. Pierwszą badaną kwestią było główne źródło informacji dla inwestora o danym emitencie. Do tego pytania badawczego postawiono hipotezę mówiącą o tym, że prospekt emisyjny lub memorandum informacyjne nie są podstawowym źródłem informacji dla inwestorów, biorących udział w publicznych emisjach obligacji. Założono, że inwestorzy ze względu na dużą objętość obu dokumentów niechętnie się z nimi zapoznają. Hipoteza ta została zweryfikowana w badaniu za pomocą pytania „skąd czerpiesz informacje na temat emisji obligacji korporacyjnych?”. W przeciwieństwie do założonej hipotezy, najliczniejsza grupa badanych, blisko $68 \%$, wskazała odpowiedź „prospekt emisyjny lub memorandum informacyjne”. Dopiero na drugim miejscu znalazły się ,artykuły prasowe i wywiady" $-55,5 \%$ badanych. Na trzecim miejscu znalazła się ,strona WWW emitenta" - tę odpowiedź wskazała równie liczna grupa badanych, jak odpowiedź drugą, tj. 52,5\%. 
Założona hipoteza nie uzyskała odzwierciedlenia w wynikach. Mimo to, warto zwrócić uwagę na dwa istotne aspekty wynikające z metodologii badania. Po pierwsze, badanie leżące u podstaw tych liczb miało charakter deklaratywny - uczestnicy wskazywali odpowiedź w warunkach niebędących częścią faktycznego procesu inwestycyjnego. Sprawić to mogło, że wskazywali najczęściej tę odpowiedź, która wydawała im się najbardziej właściwa. W tej sytuacji, aby faktycznie zbadać czy prospekt emisyjny jest najważniejszym źródłem informacji, trzeba by przeprowadzić inny rodzaj obserwacji. Konieczne byłoby uzyskanie informacji o liczbie faktycznych pobrań (np. ze strony WWW emitenta) prospektu emisyjnego i skonfrontowanie tej liczby z ilością inwestorów, którzy wzięli udział w ofercie, a także z wynikami niniejszego badania.

Po drugie, należy zwrócić uwagę na fakt, że w badaniu wzięły udział osoby, z których niemal połowa posiada staż inwestorski wynoszący ponad 10 lat, a niemal $40 \%$ deklaruje wartość portfela inwestycyjnego od 100 tys. do 500 tys. zł. Z tego punktu widzenia można założyć, że w dużej mierze mamy do czynienia z inwestorami półprofesjonalnymi i doświadczonymi ze stosunkowo dużym kapitałem. Faktycznie więc robią to, co deklarują, czyli w pierwszej kolejności czerpią informacje o warunkach emisji obligacji i samym emitencie z prospektu emisyjnego. W związku z tym przyjmujemy, że założona hipoteza nie została zweryfikowana pozytywnie.

Ry s u n e k. Rozkład odpowiedzi na pytanie: skąd czerpiesz informacje na temat emisji obligacji korporacyjnych? $(\mathrm{N}=261$, pytanie wielokrotnego wyboru)
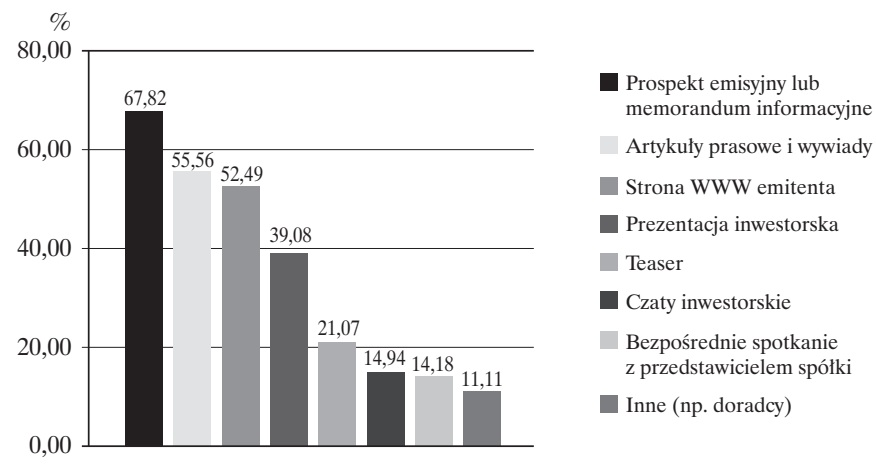

Źródło: opracowanie własne.

$\mathrm{Na}$ dalszym etapie badania postawiono pytanie, jakiego zabezpieczenia obligacji oczekują inwestorzy przy publicznych emisjach obligacji. Odpowiedzi miały zweryfikować kolejną postawioną hipotezę, dotyczącą oczekiwa- 
nego zabezpieczenia. W przypadku zabezpieczenia obligacji, wyniki badania potwierdzają przyjętą hipotezę, że inwestorzy najchętniej oczekują zabezpieczenia obligacji hipoteką. Taką odpowiedź wybrało $56 \%$ badanych. Na drugim miejscu znalazła się odpowiedź wybrana przez znacznie mniej uczestników badania, bo niecałe $13 \%$ - dobrowolne poddanie się egzekucji.

Ry s u n e k 7. Rozkład odpowiedzi na pytanie: jaka forma zabezpieczenia obligacji korporacyjnych jest Twoim zdaniem najlepsza? $(\mathrm{N}=261$, pytanie jednokrotnego wyboru)

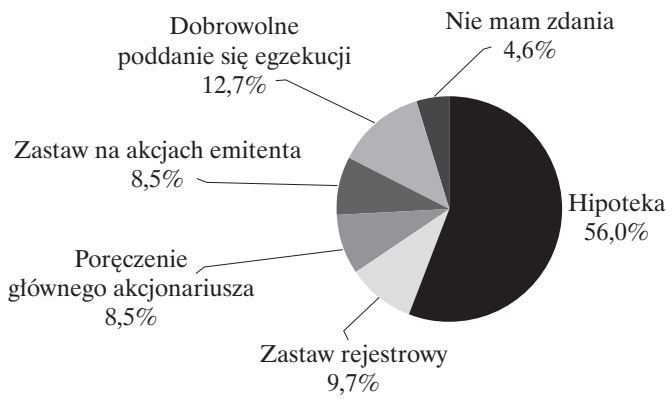

Źródło: opracowanie własne.

W tym wypadku wynik nie jest zaskakujący. Biorąc pod uwagę specyfikę polskiego prawa i uwarunkowania gospodarcze, nie może dziwić, że inwestorzy największą wartość zabezpieczającą ich inwestycję upatrują właśnie w hipotece. Może to mieć też znaczenie psychologiczne związane z tym, że inwestorzy oczekują realnego zabezpieczenia, jakim jest nieruchomość.

Postanowiono również zbadać czynniki decydujące o zainwestowaniu w daną emisje obligacji korporacyjnych. Intuicja podpowiada, że inwestorzy obejmujący obligacje w publicznych emisjach będą zwracać uwagę w pierwszej kolejności na ich oprocentowanie. Taka więc została przyjęta hipoteza dla tej części badania. Wyniki pozwoliły ją potwierdzić, ale pokazały inne, niemal równie istotne czynniki, decydujące o zainwestowaniu w daną emisję obligacji korporacyjnych. 
Ry s u n e k 8. Rozkład odpowiedzi na pytanie: jakie czynniki bierzesz pod uwagę przy podejmowaniu decyzji o inwestowaniu w obligacje korporacyjne? ( $N=261$, pytanie wielokrotnego wyboru)
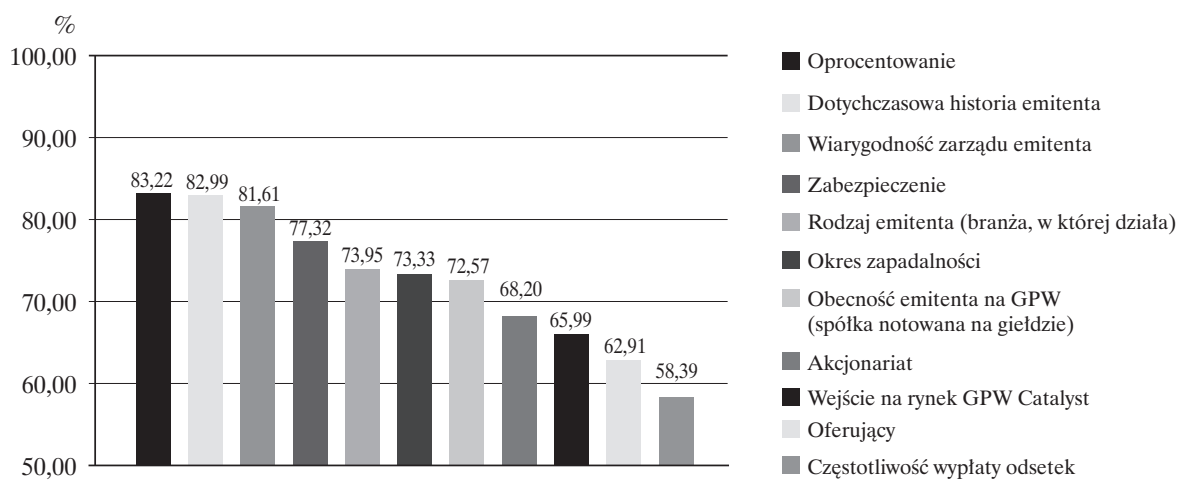

Źródło: opracowanie własne.

Najistotniejszym czynnikiem decydującym o zainwestowaniu w daną emisję obligacji korporacyjnych jest oprocentowanie, które w skali od 1 do 5 otrzymało średnią ocenę 4,16. Pozwala to potwierdzić przyjętą hipotezę. Jednak, niemniej istotnym (na granicy błędu statystycznego) czynnikiem jest według uczestników badania dotychczasowa historia emitenta (ocena 4,15) oraz wiarygodność zarządu emitenta (ocena 4,08). Rezultat jest interesujący, ponieważ może wynikać z dwóch powodów: sytuacji na rynku obligacji w 2018 r. oraz rosnącego poziomu wiedzy polskich inwestorów na temat obligacji jako instrumentu finansowego. $\mathrm{Z}$ tego punktu widzenia, ciekawym rozwinięciem tej kwestii byłoby ponowne przeprowadzenie badania za jakiś czas i analiza czy tak baczne zwracanie uwagi na dotychczasową historię emitenta, czy wiarygodność zarządu jest swego rodzaju pozytywną anomalią, charakterystyczną dla etapu rozwoju rynku obligacji czy też trwałą tendencją. Mogłaby ona wynikać z rosnącego stażu polskich inwestorów, a co za tym idzie - ich wiedzy i doświadczenia.

U źródła postawienia ostatniego pytania badawczego dotyczącego tego, jak oprocentowanie obligacji wpływa na skłonność inwestorów do zapoznania się 
$\mathrm{z}$ informacjami o emitencie było kilka emisji obligacji uplasowanych na rynku na przestrzeni lat 2016-2018. Można było zauważyć tendencję, w ramach której nawet stosunkowo ryzykowne z punktu widzenia inwestorów przedsiębiorstwa sięgały po tę formę finansowania jako alternatywę (lub uzupełnienie) do finansowania akcyjnego. U podstaw tego pytania leżało też założenie, że inwestorzy, którzy obejmują obligacje z wyższym oprocentowaniem, będą wykazywać się większą skłonnością do ryzyka i tym samym przypuszczalnie w mniejszym stopniu czytają prospekt emisyjny. W celu weryfikacji tego założenia w kwestionariuszu ankiety znalazły się dwa pytania: „w jakim stopniu czytasz prospekt emisyjny?” oraz „czy zainwestowałbyś w obligacje korporacyjne o podanym oprocentowaniu?". Analiza krzyżowa odpowiedzi na pytania pozwoliła stwierdzić, w jakim stopniu osoby skłonne zainwestować w obligacje o wyższym oprocentowaniu będą czytać prospekt emisyjny. Jak jednak pokazały wyniki, nie ma różnicy pomiędzy osobami skłonnymi zainwestować w obligacje o niższym oprocentowaniu (np. 4-5\%) i wyższym oprocentowaniu (np. 9-10\%). Deklarowany stopień czytania prospektu emisyjnego jest taki sam w przypadku inwestorów skłonnych zainwestować w obligacje z niższym czy z wyższym oprocentowaniem. Postawiona hipoteza nie może zatem zostać zweryfikowana pozytywnie.

Ry s u n e k. Rozkład stopnia czytania prospektu emisyjnego i skłonność do zainwestowania przy określonym oprocentowaniu obligacji ( $N=261$, analiza krzyżowa odpowiedzi na pytania jednokrotnego wyboru)

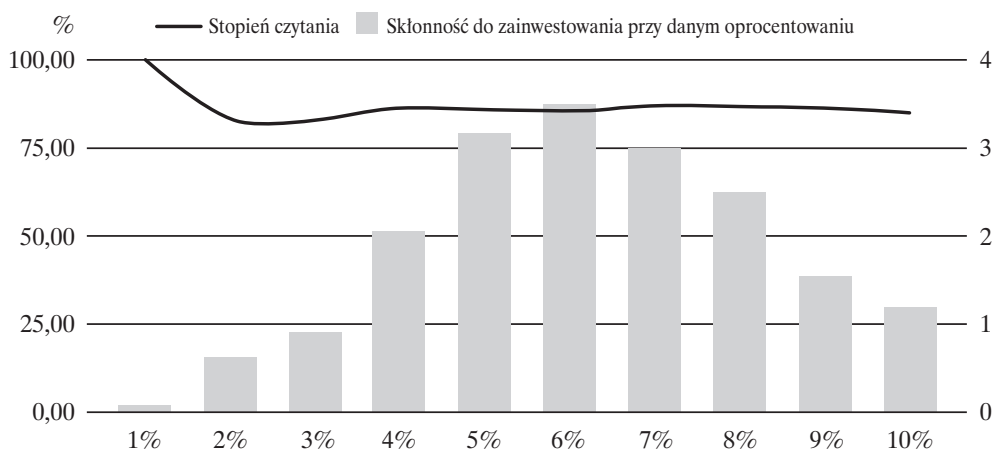

Źródło: opracowanie własne.

Oczywiście, w przypadku tego pytania, przy analizie wyników warto pamiętać o metodologii. Badanie miało charakter deklaratywny, należy więc wziąć pod uwagę, że w rzeczywistości inwestorzy mogą czytać prospekt emisyjny 
w innym stopniu niż deklarują. Różnica może wynikać z przekonania badanych o tym, że będąc inwestorem należy czytać prospekt emisyjny obligacji (tak powinno się robić, to jest właściwe zachowanie). W praktyce jednak, kiedy uwzględnimy okoliczności, proces sprzedaży obligacji, presję czasu czy inne zajęcia inwestorów, mogłoby się okazać, że mało osób tak dużą wagę przywiązuje do lektury prospektu emisyjnego i bazują głównie (jak pokazały wyniki dot. czynników) na oprocentowaniu, dotychczasowej historii emitenta czy wiarygodności zarządu. Te informacje ciężko znaleźć w prospekcie emisyjnym, a zwłaszcza tak niepoliczalną, jak wiarygodność zarządu emitenta.

\section{Oczekiwania inwestorów wobec komunikacji emitentów}

Realizacja założonego celu artykułu wymagała weryfikacji postawionych hipotez oraz odpowiedzi na pomocnicze pytania badawcze. W badaniu zakładano więc dodatkowe pytania kwestionariuszowe, które miały w tym pomóc. Zapytano osoby badane, jakich informacji poszukują na stronie WWW emitentów, o co pytają w czasie kontaktu z przedstawicielami emitentów oraz jaka forma komunikacji jest dla nich najbardziej wartościowa.

Ry s u n e 10. Rozkład odpowiedzi na pytanie: jakich informacji szukasz na stronie WWW emitenta obligacji korporacyjnych?

( $N=261$, pytanie wielokrotnego wyboru)

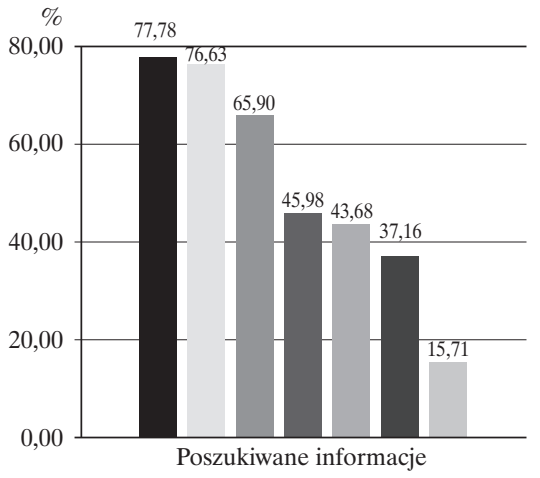

Warunków emisji obligacji

(oprocentowanie, terminy wypłaty odsetek etc.)

Wyników finansowych spółki

Prospektu emisyjnego

Harmonogramu oferty

Prezentacji inwestorskiej

Informacji o zapisach - domy maklerskie

Teaser'a

Źródło: opracowanie własne.

W pytaniu o informacje na temat emisji obligacji poszukiwane na stronie WWW osoby badane zadeklarowały, że w pierwszej kolejności (77\% badanych wskazało taką odpowiedź) interesują je warunki obligacji (tj. oprocentowanie, terminy, wypłaty odsetek itp.). Kolejna najliczniej wybierana odpowiedź to 
wyniki finansowe spółki (76\%) oraz prospekt emisyjny (65\%). Rzadziej wskazywanymi odpowiedziami (poniżej 50\%) były harmonogram oferty, prezentacja inwestorska, informacje o zapisach oraz teaser.

Warto zwrócić tutaj uwagę na fakt, że z jednej strony w innym pytaniu badani deklarowali, że najważniejszym źródłem informacji na temat emisji obligacji jest prospekt emisyjny, a w przypadku tego pytania wskazują, że w pierwszej kolejności szukają warunków emisji. Można by zatem wnioskować, że pojawia się tutaj sprzeczność, jednak naszym zdaniem nie musi tak być. Należy pamiętać, że wszystkie te informacje znajdują się w prospekcie emisyjnym, więc inwestorzy wskazują go jako najważniejsze źródło informacji w zadanym pytaniu.

Ważnym aspektem prowadzenia relacji inwestorskich z punktu widzenia emitentów jest przygotowanie się na komunikację bezpośrednią ze strony inwestorów zainteresowanych wzięciem udziału w emisji obligacji. Wychodząc $\mathrm{z}$ tego założenia, zapytano osoby badane, jaka forma komunikacji z emitentem jest dla nich najbardziej wartościowa. Blisko $40 \%$ uczestników badania wybrało e-mail do przedstawiciela spółki, ponad $27 \%$ osobiste spotkanie z przedstawicielami spółki, a blisko $20 \%$ czat inwestorski. Taki rozkład odpowiedzi sugeruje, że elektroniczne, tekstowe formy komunikacji, jak e-mail czy czat inwestorski są obecnie kluczowym sposobem komunikacji inwestorów z emitentem. Spółki prowadzące emisje obligacji powinny więc o tym pamiętać i być na to przygotowane.

Ry s u n e 11. Rozkład odpowiedzi na pytanie: jaka forma komunikacji z emitentem obligacji korporacyjnych jest dla Ciebie najbardziej wartościowa?

( $N=261$, pytanie jednokrotnego wyboru)

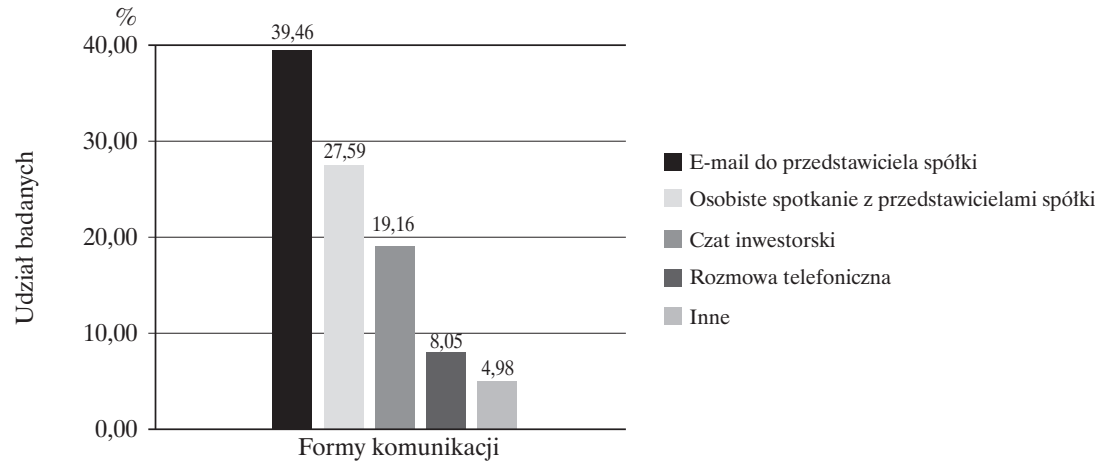

Źródło: opracowanie własne. 
W przypadku pytania na temat zagadnień poruszanych w ramach kontaktu $\mathrm{z}$ przedstawicielami emitenta, osoby badane wskazywały w pierwszej kolejności (ponad 62\%) kwestie związane z wynikami finansowymi i bilansem spółki. Kolejną istotną kwestią były ryzyka (57\%), a trzecią najczęściej wskazywaną odpowiedzią ( $56 \%$ badanych) zabezpieczenie emisji.

R y s u n e k 12. Rozkład odpowiedzi na pytanie: o co najczęściej pytasz w czasie kontaktu ze spótką (na spotkaniach, w mailach, na czatach inwestorskich)? ( $\mathrm{N}=261$, pytanie wielokrotnego wyboru)

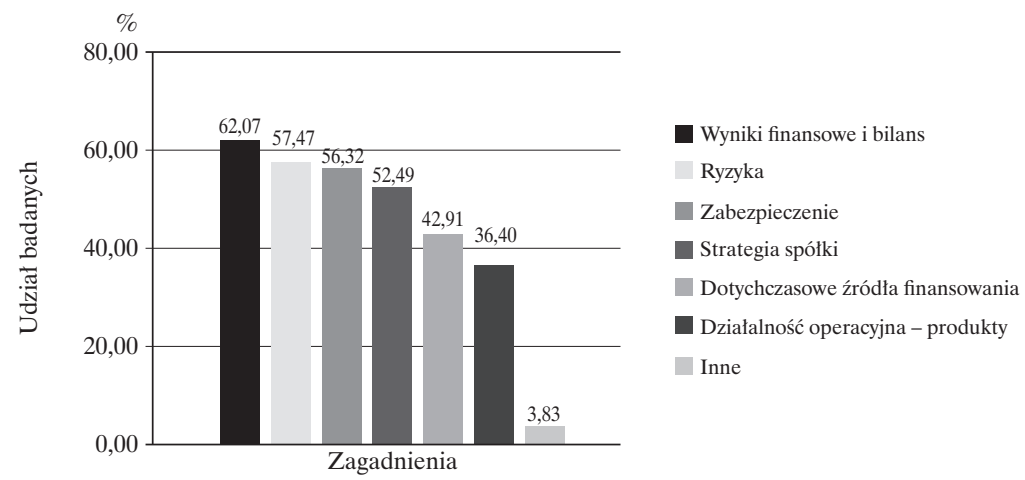

Źródło: opracowanie własne.

Prowadząc badanie, zdecydowano się zapytać jego uczestników w branże jakiego emitenta są skłonni zainwestować. Dane te pokazuje rysunek 13.

Ry s u n e k 13. Rozkład odpowiedzi na pytanie: kreśl w jakim stopniu byłbyś skłonny zainwestować w obligacje korporacyjne emitenta $\mathrm{z}$ danej branży ( $N=261$, zestawienie odpowiedzi na pytania jednokrotnego wyboru)

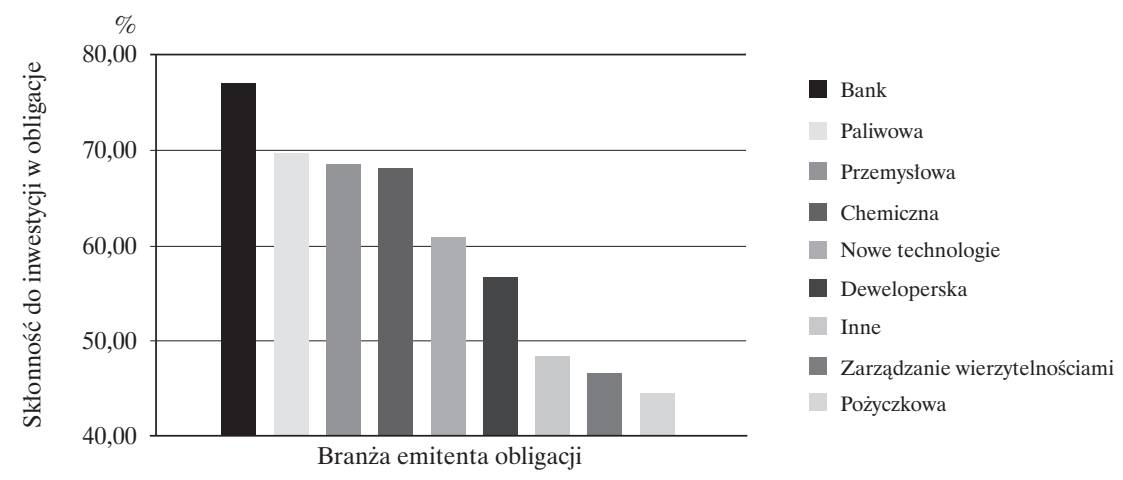

Źródło: opracowanie własne. 
Jak pokazują wyniki, na powodzenie danej emisji obligacji mają wpływ nie tylko relacje inwestorskie, lecz także, a być może przede wszystkim, czynniki do pewnego stopnia niezależne od emitenta. Widać, że w obecnej sytuacji (dane z sierpnia 2018 r.) inwestorzy wykazują największą skłonność (na poziomie blisko $80 \%$ ) do zainwestowania w obligacje emitenta $\mathrm{z}$ branży bankowej. W drugiej kolejności (blisko 70\%) są emitenci z branży paliwowej, a na kolejnych wysokich pozycjach (ponad 65\%) emitenci z branży przemysłowej czy chemicznej. Widać natomiast wyraźnie, jak małym zainteresowaniem cieszyłyby się aktualnie emisje obligacji emitentów z branży zarządzania wierzytelnościami czy pożyczkowej. Skłonność do inwestycji w takiego emitenta badani określili na poziomie ok. $45 \%$, czyli niemal o $50 \%$ gorzej niż w przypadku lidera zestawienia, tj. branży bankowej.

\section{Podsumowanie}

Celem niniejszego artykułu było poznanie oraz sklasyfikowanie potrzeb i zachowań inwestorów w kontekście relacji inwestorskich prowadzonych przez emitentów obligacji w publicznych emisjach. Jego realizacja została oparta na badaniu, które przeprowadzono na grupie celowej składającej się z 554 uczestników - czytelników serwisu internetowego StrefaInwestorow.pl. Udział w badaniu był dobrowolny, a o jego przebiegu czytelnicy byli szeroko informowani. Jednak właściwy kwestionariusz dotyczący obligacji wypełniali jedynie uczestnicy, którzy zadeklarowali, że inwestowali już w obligacje. Takich osób było 261, czyli niespełna połowa osób, która wzięła udział w badaniu. Za pomocą pytań metryczkowych scharakteryzowano tę grupę. Dominują w niej osoby, które od ponad 5 lat zajmują się inwestycjami, robią to głównie samodzielnie, a $60 \%$ uczestników badania to inwestorzy z istotnym portfelem inwestycyjnym, bo o wartości co najmniej 50 tys. zł. Dodatkowo, zdecydowaną większość stanowią inwestorzy z wykształceniem wyższym, którzy zadeklarowali (ponad 70\%), że inwestują w obligacje w publicznych emisjach.

W artykule postawiono cztery pomocnicze pytania badawcze oraz hipotezy. W pierwszej części zbadano co jest głównym źródłem informacji dla inwestorów, a założona hipoteza mówiła, że nie jest to prospekt emisyjny ani memorandum. Okazało się jednak, że inwestorzy deklarują właśnie te oficjalne dokumenty jako najważniejsze z ich punktu widzenia. Można jednak przypuszczać, że właśnie dlatego deklarują takie odpowiedzi, ponieważ większość osób badanych to doświadczeni inwestorzy. Mimo to, ważnymi źródłami informacji o emisjach są również wywiady i artykuły prasowe oraz strona internetowa. 
Emitenci, prowadząc relacje inwestorskie, mają zatem tutaj spore pole do działania, mają bowiem na te kwestie bezpośredni wpływ.

W dalszej części artykułu zbadano jakiego zabezpieczenia oczekują inwestorzy. Założona hipoteza mówiąca o tym, że jest to hipoteka została zweryfikowana pozytywnie. Kluczowa zatem jest komunikacja związana z zabezpieczeniem, tak aby tłumaczyć jego rolę. Dużym wyzwaniem jest natomiast posiadanie innego zabezpieczenia niż hipoteka, ponieważ $56 \%$ inwestorów zadeklarowała, że oczekuje właśnie takiego zabezpieczenia.

Zbadano też, jakie czynniki decydują o inwestowaniu w obligacje, stawiając hipotezę, że jest to oferowane oprocentowanie. Hipoteza ta potwierdziła się, natomiast równie istotne są dla inwestorów takie czynniki, jak dotychczasowa historia emitenta i wiarygodność zarządu. Znowu dla emitentów jest tutaj przestrzeń do pracy w zakresie komunikacji, ponieważ dobrze i trwale prowadzone relacje inwestorskie pozytywnie wpływają na ocenę wiarygodności emitenta. O tym wyniku warto także pamiętać, przygotowując działania komunikacyjne w ramach emisji obligacji, podkreślając nie tylko kwestie związane z oprocentowaniem, lecz także z dotychczasową historią czy wiarygodnością zarządu emitenta.

W ostatniej części badania sprawdzono jak oprocentowanie obligacji wpływa na skłonność do zapoznania się z informacjami o emitencie. Postawiono hipotezę, że inwestorzy kupujący obligacje z wyższym oprocentowaniem w mniejszym stopniu czytają prospekt emisyjny czy memorandum. Na podstawie przeprowadzonego badania okazało się, że nie ma takiej zależności.

Realizacja celu całego badania wymagała zadania jeszcze dodatkowych pytań w kwestionariuszu. Okazało się, że inwestorzy na stronie internetowej emitenta poszukują głównie informacji o warunkach emisji obligacji. Kolejnymi najliczniej wybieranymi odpowiedziami były wyniki finansowe oraz prospekt emisyjny. Zbadano też z jakiej formy bezpośredniego kontaktu najchętniej korzystają inwestorzy. Okazało się, że najchętniej wybierają e-mail czy czat inwestorski. Zatem potwierdza się, że emitenci głównie powinni stawiać na narzędzia komunikacji elektronicznej i je poprawnie obsługiwać. W pytaniu, jakich informacji poszukują inwestorzy w kontakcie z emitentem, najwięcej badanych pyta o wyniki finansowe spółki, ryzyka jej działania oraz zabezpieczenie.

Ponadto, biorąc pod uwagę wydarzenia związane z niewypłacalnością czołowej firmy windykacyjnej, zapytano też o branże, w jakie najchętniej zainwestowaliby inwestorzy. Okazało się, że aktualnie branża windykacyjna i pożyczkowa może mieć kłopoty z pozyskiwaniem finansowania w publicznych emisjach 
obligacji, natomiast banki, branża chemiczna czy przemysłowa są najbardziej preferowane wśród inwestorów indywidualnych.

Podsumowując, wyniki badania pokazały kilka istotnych czynników zarówno zależnych, jak i niezależnych od emitentów. Widać jednak wyraźnie, że jest wiele czynników, na które emitenci mają bezpośredni wpływ, prowadząc bieżące relacje inwestorskie czy już w sytuacji prowadzenia oferty obligacji. Emitenci obligacji, chcący zwiększyć prawdopodobieństwo sukcesu w emisji obligacji, powinni o tych wszystkich aspektach pamiętać.

Oczywiście mamy pełną świadomość faktu, że badanie było prowadzone w specyficznej sytuacji, w momencie, w którym zaufanie do rynku obligacji jako całości było na stosunkowo niskim poziomie. Dlatego też, płynie z niego co najmniej kilka uniwersalnych wniosków, co starano się pokazać w tym artykule. Jednocześnie, wiele wątków badania można by kontynuować i znacznie rozszerzyć, jak pokazują bowiem ostatnie lata, rynek obligacji korporacyjnych ulega ciągłym zmianom i emitenci, którzy chcą osiągać na nim sukces, powinni te zmiany dostrzegać i, bazując na sprawdzonych informacjach oraz doświadczonych doradcach, się do nich dostosowywać.

\section{Bibliografia}

Dziawgo, D. (2011). Relacje inwestorskie. Ewolucja, funkcjonowanie, wyzwania. Warszawa: PWN.

Łukasik, G. (2014). Kontrowersje wokół polityki informacyjnej spółek kapitałowych wobec inwestorów. Studia Ekonomiczne. 198(2), 109-121.

Krug, A. (2008). Relacje inwestorskie jako narzędzie budowania zaufania uczestników rynku finansowego. Prace Naukowe Akademii Ekonomicznej we Wroctawiu. Problemy gospodarki światowej, 1191, 265-278.

Olędzki, J. i Tworzyło, D. (2006). Public relations znaczenie społeczne i kierunki rozwoju. Warszawa: PWN.

Rawicki, T. (2011). Tworzenie wartości dla akcjonariuszy przez relacje inwestorskie. Kwartalnik Nauk o Przedsiębiorstwie, (4).

Rawicki, T. (2012). Obniżenie kosztu kapitału przez relacje inwestorskie. Kwartalnik Nauk o Przedsiębiorstwie, (3).

Szablewski, A. i Panfil, M. (2006). Metody wyceny spótki perspektywa klienta i inwestora. Warszawa: Poltext.

Szamańska, A. (2005). Public relations w systemie zintegrowanej komunikacji marketingowej. Warszawa: Unimex. 


\title{
Rozdział 8
}

\author{
IRENEUSZ MICIUŁA*
}

\section{Globalny rozwój i perspektywy implementacji kryptowalut a stan tego rynku w Polsce}

\begin{abstract}
Rozwój rynku kryptowalut i implikacje dla całej gospodarki oraz wpływ finansowy na wszystkich uczestników rynku powodują duże zainteresowanie tematem. Artykuł omawia funkcjonowanie i możliwe perspektywy rozwoju globalnego rynku kryptowalut i jego znaczenia dla gospodarek. W ramach analizy z jednej strony wyciagnięto wnioski z historii najpopularniejszej kryptowaluty - bitcoina, z drugiej zaś - dokonano oceny stanu oraz struktury polskiego rynku kryptowalut na tle światowych przemian.

Celem artykułu jest ocena stanu polskiego rynku kryptowalut na tle rozwoju tego rynku na świecie oraz przedstawienie możliwych perspektyw rozwoju. W ramach oceny rynku kryptowalut wykorzystano dane ilościowe i jakościowe zawarte w badaniach statystycznych i raportach ilościowych, krajową i zagraniczną literaturę przedmiotu oraz studia przypadków dla konkretnych rozwiązań wprowadzanych na omawianym rynku. Badanie to pozwala na ukazanie możliwych perspektyw rozwoju rynku kryptowalut w Polsce i na świecie.
\end{abstract}

Słowa kluczowe: kryptowaluty, innowacje technologiczno-finansowe, rynek kryptowalut, giełdy kryptowalut, regulacje rynkowe.

\section{Global Development and Prospects of Cryptocurrency Implementation and the State of This Market in Poland}

The development of the cryptocurrency market and implications for the entire economy as well as the financial impact on all market participants cause a lot of interest in this topic. The article discusses the functioning and possible prospects for the development of the global cryptocurrency

* Dr inż. Ireneusz Miciuła - Instytut Ekonomii i Finansów, Wydział Ekonomii, Finansów i Zarządzania, Uniwersytet Szczeciński, Al. Papieża Jana Pawła II 22a, 70-453 Szczecin, Polska; e-mail: ireneusz.miciula@usz.edu.pl; https://orcid.org/0000-0003-3150-4490. 
market and its significance for economies. As part of the analysis, on the one hand, lessons were drawn from the history of the most popular cryptocurrency, Bitcoin. On the other hand, an assessment of the condition and structure of the Polish crypto market was made against the background of global changes.

The aim of the article is to assess the condition of the Polish crypto market on the background of the development of this market in the world and to present possible development perspectives. As part of the cryptocurrency market evaluation, quantitative and qualitative data, included in statistical surveys and quantitative reports, national and foreign literature on the subject, as well as case studies for specific solutions introduced on the discussed market, were used. This research allows to show possible development prospects for the crypto market in Poland and worldwide.

Keywords: cryptocurrencies, technological and financial innovations, cryptocurrency market, cryptocurrencies exchanges, market regulations.

JEL: A11, C90, E00, E42, F30, F65, G18, O38

\section{Wprowadzenie}

Waluta kryptograficzna, popularnie zwana kryptowalutą, jest w definicji rozproszonym systemem księgowym opartym na kryptografii, który przechowuje informacje o stanie własności w konwencjonalnych jednostkach. Stan własności jest powiązany z poszczególnymi węzłami systemu (portfelami) w taki sposób, że tylko posiadacz odpowiedniego klucza prywatnego ma kontrolę nad danym portfelem i nie ma możliwości dwukrotnego wydania tej samej jednostki. Twórca najpopularniejszej kryptowaluty definiuje go następująco: jest to elektroniczna moneta jako łańcuch cyfrowych podpisów (Satoshi, 2008). Każdy właściciel przenosi monetę do następnej, podpisując cyfrowo „hash” poprzedniej transakcji i klucz publiczny następnego właściciela, dodając je na końcu monety. Odbiorca może zweryfikować podpisy, aby zweryfikować łańcuch własności. Problem oczywiście polega na tym, że odbiorca nie może zweryfikować czy jeden z właścicieli nie wydał podwójnie pieniędzy. Powszechnym rozwiązaniem jest wprowadzenie zaufanego organu centralnego lub mennicy, która sprawdza każdą transakcję pod kątem podwójnych wydatków. Jest to powszechne rozwiązanie w tego typu systemach. Jednak powoduje utratę najczęściej głoszonej zalety takich systemów, a więc braku organów nadzorczych, które jak widać są wymagane jako niezbędny element dla zaufania systemu.

Obecny handel w Internecie opiera się na instytucjach służących jako zaufane strony trzecie do przetwarzania płatności elektronicznych. Chociaż system działa wystarczająco dobrze dla większości transakcji, nadal cierpi na nieodłączne słabości modelu opartego na zaufaniu, ponieważ nie może uniknąć 
mediacji w sporach. W związku z tym potrzebny jest system płatności elektronicznych, który umożliwi dowolnym dwóm zainteresowanym stronom dokonywanie transakcji bezpośrednio ze sobą bez potrzeby korzystania z zaufanej strony trzeciej (Investopedia, 2018). Peer-to-peer, czyli wersja elektronicznej gotówki pozwoliłaby na przesyłanie płatności online bezpośrednio z jednej strony do drugiej bez przechodzenia przez instytucję finansową. Podpisy cyfrowe stanowią część rozwiązania, ale główne korzyści są tracone, jeśli zaufana strona trzecia nadal jest zobowiązana do zapobiegania podwójnemu wydatkowaniu. System kryptowalut od strony operacyjnej opiera się na kryptologii, dziedzinie wiedzy o transmisji informacji w sposób zabezpieczony przed nieuprawnionym dostępem (Christin, 2013). Jednak system ten oparty jest również na zaufaniu przez instytucje potwierdzające autentyczność, nawet kluczy kryptograficznych. Systemy te szukają rozwiązań, które mogłyby działać bez potrzeby zaufania stron trzecich. Jednak jednocześnie mogą być źródłem kryzysów finansowych i ukrywania przestępstw, co powoduje zagrożenia i możliwe straty gospodarcze na świecie. Obecnie działające kryptowaluty oparte są głównie na zaufaniu dwustronnym (sprzedającym i inwestorach), a dodatkowo na samym końcu twórcy mają możliwość manipulowania i zmiany zasad działania algorytmów, na podstawie których działa system kryptowalut. Jest to największe niebezpieczeństwo, o czym świadczą liczne kryptowaluty, które zbankrutowały lub przestały funkcjonować z dnia na dzień. Właśnie dlatego ten temat jest tak ważny. $\mathrm{Z}$ jednej strony systemy te szukają rozwiązań, które mogłyby działać bez potrzeby zaufania stron trzecich. Globalny system kryptowalut funkcjonuje pomimo braku potwierdzenia zaufania ze strony państw i instytucji. Jednocześnie daje możliwość spekulowania i tworzenia dużych osiedli dla osób prywatnych lub przedsiębiorstw, które zasadniczo są w systemie globalnym niezauważalne dla całości. $\mathrm{Z}$ drugiej zaś - może powodować wielkie systemowe zagrożenia i ogromne straty gospodarcze na całym świecie przez bycie źródłem ukrywania wielkich przestępstw finansowych i kryzysowych.

\section{Obecny rozwój rynku kryptowalut na świecie}

Największe zainteresowanie kryptowalutami wynika z dwóch powodów. Przede wszystkim z idei wolności i niezależności od stron trzecich, takich jak państwo lub instytucje finansowe oraz z punktu widzenia możliwych zysków inwestycyjnych zarówno legalnych, jak i nielegalnych. Jedną z głównych cech kryptowalut jest to, że działa jak wirtualna waluta. Posiadacz takiej kryptowaluty przechowuje ją na swoim komputerze lub w aplikacji na smartfonie w tak zwanym portfelu, do którego ma dostęp tylko on. Jeśli chce dokonać transak- 
cji, to odbywa się ona elektronicznie, bezpośrednio między nim a wykonawcą. Każda jednostka kryptowalut posiada unikalny kod, który zawiera informacje uniemożliwiające jej kopiowanie lub ponowne wydawanie. Kluczem do koncepcji kryptowalut jest to, że w obiegu nie ma regulatora. W związku z tym nie istnieje „Centralny Bank Kryptowalut”, który może zdecydować o zwiększeniu podaży kryptowaluty, a tym samym zmniejszeniu jej wartości. Autor decyduje o tym, ile danej kryptowaluty znajduje się w obiegu na etapie tworzenia systemu. Jego wartość leży w rękach wolnego rynku. Handel kryptowalutami odbywa się drogą elektroniczną, bez udziału jakiegokolwiek systemu bankowego bezpośrednio między użytkownikami kryptowaluty, tj. w technologii peer-topeer. Oznacza to, że transakcja nie jest w żaden sposób nadzorowana (Moneycontrol, 2018). Biorąc pod uwagę powyższe, okazuje się, że misja kryptowaluty naprawdę sprowadza się do jednego słowa, którym jest „wolność”. Kryptowaluty są walutami elektronicznymi całkowicie wolnymi od kontroli polityków, krajowych lub międzynarodowych instytucji finansowych, których obroty nie są w żaden sposób kontrolowane i podlegają jedynie silnemu systemowi elektronicznych, zautomatyzowanych papierów wartościowych.

Aktualnie najpopularniejszą kryptowalutą na świecie jest bitcoin. Posiada najwyższą kapitalizację rynkową oraz najwyższy kurs i często w ramach omawiania tematu kryptowalut jest flagowym przykładem. Najbardziej popularna kryptowaluta na świecie, czyli bitcoin, powstała w 2008 roku. Nie wiadomo kto jest jej twórcą. Prawie jednocześnie trzej informatycy (King, Oksman, Bry) opatentowali rozwiązania zbliżone do tych, na których opierał się system bitcoin. Widzimy więc, że bitcoin ma już 10 lat (Rosic, 2018). Dzięki przeglądowi historii rozwoju bitcoin, można zauważyć charakterystyczne fazy dla całego rynku kryptowalut:

- 9 luty 2011 roku - po raz pierwszy w historii jeden bitcoin wyceniany był na równi z 1 dolarem amerykańskim;

- 5 kwietnia 2011 roku - powstaje polska giełda bitmarket.eu.;

- 2 czerwca 2011 roku - 1 BTC wyceniany był na 10 USD;

- 26 sierpnia 2011 roku - następuje upadek polskiej giełdy bitomat.pl, gdzie utracono 17000 BTC;

- 19 listopada 2013 roku - 1 BTC wyceniany był na 1000 USD;

- 13 luty 2012 roku - upadek dużej giełdy TradeHill;

- 11 maj 2012 roku - upadek platformy Bitcoinica;

- lipiec 2013 roku - miliarderzy, bracia Winklevoss, wchodzą w bitcoin;

- 25 marzec 2013 roku - Dania zwalnia z podatku obrót bitcoinami;

- 20 wrzesień 2013 roku - bitcoin uznany za pełnoprawny pieniądz prywatny w Niemczech; 
- 5 grudzień 2013 roku - początek banu bitcoina w Chinach;

- 28 luty 2014 roku - upadek największej giełdy bitcoin - Mt.Gox;

- 20 luty 2017 roku - za 1 bitcoina można otrzymać 1055,26 USD;

- 2 marzec 2017 roku - bitcoin wart więcej niż złoto 1268 USD za 1 BTC;

- grudzień 2017 roku - historyczna wartość maksymalna 1 bitcoin wart 20000 USD;

- 1 maj 2018 roku - za 1 bitcoina można otrzymać 8951,64 USD (31 105 PLN).

Pierwsza charakterystyczna faza, która jest zauważalna na wykresach wszystkich nowych kryptowalut to tzw. faza zdobywania zaufania. Jest widoczna na wykresach kryptowalut, które przeszły do kolejnych faz: drugiej (zainteresowania, wzrostu) i trzeciej (ustalenia wartości maksymalnej dla okresu). Czas pomiędzy kolejnymi fazami jest różny dla konkretnych kryptowalut i zależy od wielu czynników. Wiele jest przykładów kryptowalut, które powstały i upadły już w pierwszej fazie cyklu życia. Również dużo jest przykładów, które przeszły do fazy trzeciej, gdzie widoczna jest osiągnięta wartość maksymalna po czym następuje bardzo szybki spadek wartości lub momentalny upadek i kryptowaluta przestaje funkcjonować. Wiele jest przykładów, gdzie nie ma tak dużego zainteresowania ze strony inwestorów i dofinansowania jak w przypadku bitcoina, co powoduje bankructwo systemu i upadek funkcjonowania tych kryptowalut. Powoduje to wiele szkód dla zaufania systemowi kryptowalut i daje argumenty ich przeciwnikom, które ukazują wykorzystywanie systemu do tworzenia piramid finansowych i innych oszustw. Te same negatywne skutki dla systemu wywołują upadki giełd i platform wymiany kryptowalut. Chociaż w tym przypadku często zdarza się, że odpowiedzialność za te wydarzenia ponoszą również obrońcy obecnego systemu, czyli państwa i instytucje finansowe. Przykładowo w Polsce nakładane są dodatkowe podatki, a instytucje finansowe, takie jak banki, odmawiają świadczenia usług na rzecz takich podmiotów. Analizując historię najpopularniejszej kryptowaluty, widzimy, że państwa mają różne podejście do systemu kryptowalut, od całkowitego zakazu i ustanawiania kar do pełnej uznawalności. Część państw często korzysta z nałożonych obciążeń podatkowych nałożonych na kryptowaluty, ale nie zamierza ustanawiać konkretnych przepisów prawa w tej kwestii, choć uznaje tę działalność za legalną.

Najnowsza historia bitcoina, w zasadzie z ostatniego roku 2017 pokazuje ponowne zainteresowanie i niewyobrażalny wręcz wzrost wartości. Od powrotu i przebicia wartości 1000 USD do aż 20000 USD w połowie grudnia 2017 za jednego bitcoin. Od tamtej pory przez niecałe pół roku mamy do czynienia ze 
spadkiem w okolice jednej czwartej historycznej wartości maksymalnej, ponowny wzrost i oscylację w okolicach połowy tej wartości, co widać na rysunku 1.

Ry s u n e 1. Wartości kursu bitcoin w latach 2015-2018

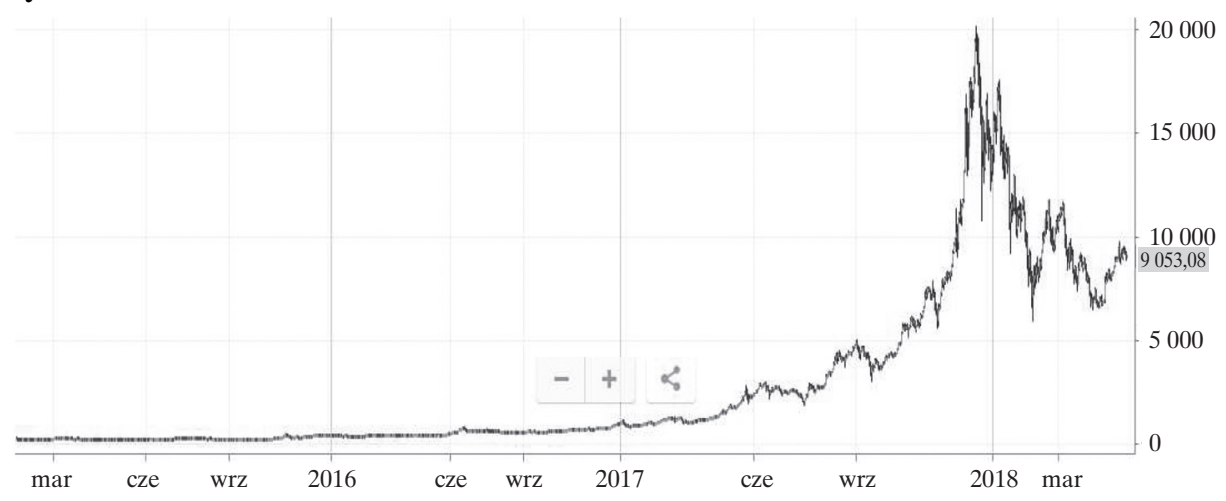

Źródło: www.coindesk.com, (15.10.2018).

Bitcoin jest flagowym przykładem systemu kryptowalut, z których większość powtarza prawidłowości zachowań tego systemu. Obecnie notowanych jest ponad tysiąc pięćset kryptowalut na ponad siedmiu tysiącach specjalnych giełdach (tak zwanych kryptogiełdach). Duża liczba, szczególnie lokalnych kryptowalut, ma krótką historię funkcjonowania, po czym znika z rynku. Powoduje do negatywne skutki dla odbierania systemu kryptowalut jako całości, ponieważ istnieje wiele przykładów na wykorzystanie go dla celów oszustw finansowych. Niewątpliwie jednak istnieją również zalety, których uwypuklenie i pełne wykorzystanie możliwości wymagałoby pewnych rozwiązań prawnych i technologicznych. Dla potwierdzenia znaczenia tematyki w świecie finansów i gospodarek na świecie w tabeli 1 przedstawiono kryptowaluty, których kapitalizacja rynkowa wynosi obecnie ponad miliard dolarów amerykańskich.

Tabela nr 1 zawiera listę kryptowalut $\mathrm{z}$ kapitalizacją rynkową przekraczającą 1 miliard USD. Aktualnie takich kryptowalut jest 25. Kapitalizacja rynkowa to wartość wszystkich monet, które są w obiegu przemnożone przez ich aktualną wartość.

kapitalizacja rynkowa $=$ ilość monet $w$ obiegu $x$ wartość aktualna jednej monety (kurs) (1)

przy czym kurs definiuje cenę jednej monety digitalnej w dolarach amerykańskich. 
Ta b e I a 1. Kryptowaluty o kapitalizacji rynkowej ponad 1 miliard USD

\begin{tabular}{|l|l|r|r|r|}
\hline \multicolumn{1}{|c|}{ Kryptowaluta } & \multicolumn{1}{|c|}{ Kod } & Kurs (w USD) & \multicolumn{1}{c|}{ Liczba monet } & Kapitalizacja rynkowa (w USD) \\
\hline Bitcoin & BTC & 8951.6394 & 17180188 & $153,790,855,757$ \\
\hline Ethereum & ETH & 646.5789 & 100154753 & $64,757,950,249$ \\
\hline Ripple & XRP & 0.80371665 & 39541619593 & $31,780,258,035$ \\
\hline Bitcoin Cash & XBC & 1281.7728 & 17275946 & $22,143,838,920$ \\
\hline EOS & EOS & 16.7904 & 835329772 & $14,025,521,010$ \\
\hline Cardano & ADA & 0.3254823 & 26188960137 & $8,524,042,980$ \\
\hline Litecoin & LTC & 143.9658 & 56898395 & $8,191,423,098$ \\
\hline Stellar Lumes & XLM & 0.39935016 & 18759309869 & $7,491,533,398$ \\
\hline Tronix & TRX & 0.09088398 & 66412089292 & $6,035,794,995$ \\
\hline NEO & NEO & 80.4078 & 65659718 & $5,279,553,500$ \\
\hline IOTA & IOT & 1.8513 & 2800940157 & $5,185,380,514$ \\
\hline Monero & XMR & 230.3433 & 16146465 & $3,719,230,081$ \\
\hline Dash & DASH & 454.2615 & 8121006 & $3,689,060,743$ \\
\hline Nem & XEM & 0.39074508 & 9090909088 & $3,552,227,999$ \\
\hline Tether & USDT & 0.99 & 2450101824 & $2,425,600,806$ \\
\hline Vechain & VEN & 4.3362 & 530773566 & $2,301,540,339$ \\
\hline Etherum Classic & ETC & 20.7207 & 102514915 & $2,124,180,807$ \\
\hline Qtum & QTUM & 21.4731 & 89476920 & $1,921,346,857$ \\
\hline OmiseGO & OMG & 16.1964 & 103074544 & $1,669,436,555$ \\
\hline Binance Coin & BNB & 13.7511 & 115221419 & $1,584,421,260$ \\
\hline Lisk & LSK & 12.2463 & 106472521 & $1,303,894,445$ \\
\hline RaiBlocks & XRB & 9.4347 & 134639002 & $1,270,278,593$ \\
\hline Bitcoin Gold & BTG & 69.7455 & 17146505 & $1,195,891,577$ \\
\hline Verge & XVG & 0.07307982 & 15092890527 & $1,102,985,723$ \\
\hline Zcash & ZEC & 272.6064 & 3856723 & $1,051,367,505$ \\
\hline Zn & & \\
\hline
\end{tabular}

Źródło: opracowanie własne na podstawie kursów z dnia 01.05.2018.

Kryptowaluta jest pierwszym wynalazkiem w systemie finansowym, który został opracowany poza instytucjami finansowymi, nawet bez współpracy z nimi. Jest nowatorski i nie wykorzystuje istniejącego sposobu funkcjonowania systemów finansowych. Co więcej, stanowi zagrożenie dla status quo systemu finansowego. Niewątpliwie ta cecha niezależności i braku konieczności zaufania trzeciej stronie (instytucjom tworzącym i regulującym system finansowy) byłaby rewolucją w świecie finansów, gdzie wymagane byłyby jedynie dwie strony transakcji. Jest to główny argument za tworzeniem systemu, który nie jest zależny i poddany wpływom regulatorów finansowych. W praktyce jednak, mimo wizji rozproszenia systemu i zależności tylko od stron transakcji, 
tak to niestety nie funkcjonuje. W rzeczywistości system oparty na technologii również posiada regulatory i opiera się na zaufaniu, ale jest to naturalna cecha systemów społecznych, które muszą być oparte na uznawalności społecznej. Natomiast wiele kryptowalut i giełd wymiany zależy niestety od grupy osób lub wręcz jednej osoby, która może mieć niegodziwe zamiary, czego przykładem jest wiele oszustw związanych z rynkiem kryptowalut. $\mathrm{Z}$ jednej strony manipulacji dokonują twórcy lub regulatorzy zasad funkcjonowania, łącznie ze zmianami w samym algorytmie, z drugiej zaś - gracze posiadający olbrzymi wpływ na cały rynek. Doskonałym przykładem jest najpopularniejsza kryptowaluta, gdzie $97 \%$ waluty jest w rękach zaledwie $4 \%$ wszystkich portfeli (Chaparro, 2018). Dlatego też coraz więcej osób i instytucji ze świata finansów przestrzega przed inwestowaniem w kryptowaluty, mówiąc o piramidzie finansowej, bańce spekulacyjnej czy zwykłych oszustwach. Obecnie, gdy nie funkcjonują jako prawne środki płatnicze, jest to forma spekulacji lub tezauryzacji wartości.

Niewątpliwie technologia ta posiada wielkie możliwości, dlatego też tak trudno zdefiniować system, który funkcjonowałby w bezpieczny sposób. Jednak ustanowienie takiego systemu w rzeczywistości nie jest zadaniem łatwym i wymaga strony zaufanej, która będzie czuwać nad bezpieczeństwem obrotów. Wydaje się, że finansowy system na bazie omawianej technologii powinien zmierzać w tę stronę. Aktualnie pomimo wielkiego zainteresowania sam problem nie jest do końca rozpoznany, o czym świadczą chociażby różne podejścia krajów świata do odpowiedniego stosowania tej technologii.

\section{Stan polskiego rynku kryptowalut}

Rozwój rynku kryptowalut w danym państwie zależy od decyzji prawnych rządów w stosunku do tego rynku. Jak już wcześniej wspomniano, możliwości jest dużo, od całkowitego zakazu, do pełnego przyjęcia jako pełnoprawnego środka płatniczego, a pomiędzy jest jeszcze dużo innych możliwości i rozwiązań. Obecnie na liście państw, przez które przechodzą największe kryptowalutowe transakcje, Polska zajęła 24 miejsce. Oczywiście ma to również związek z decyzjami państwa odnośnie do rynku kryptowalut. Aktualnie w Polsce kryptowaluty nie są uznawane za jednostkę walutową, środek płatniczy czy też pieniądz elektroniczny. Tworzenie jednostek w ramach wbudowanego w system algorytmu (tzw. wydobywanie lub wykopywanie) jest jednak legalne. Natomiast często zdarza się, że kryptowaluty nie korzystają z ulg podatkowych przewidzianych dla handlu walutą. Zresztą odnosi się wrażenie, że, podobnie jak w Polsce, państwa celowo nakładają obciążenia podatkowe, zyskowne dla budżetu państwa. Dodatkowo w wielu państwach występuje dezinformacja 
i brak regulacji. Dlatego opodatkowanie obrotu kryptowalutami budzi szereg kontrowersji. Można śmiało powiedzieć, że jest to jeden z tych przykładów, gdzie regulacje prawne nie nadążają za rzeczywistością gospodarczą. 20 kwietnia 2018 roku odbył się w Polsce protest przeciwko niejasnemu wprowadzaniu obowiązków podatkowych w stosunku do obrotu kryptowalutami. Aktualnie w zakresie podatku dochodowego od osób fizycznych uzyskany przychód z tytułu sprzedaży zakupionych kryptowalut będzie stanowić przychód z praw majątkowych, o których mowa w ww. art. 18 ustawy o podatku dochodowym od osób fizycznych (Ratajczak, 2018). Konsekwencją uzyskiwania przychodu z praw majątkowych jest spoczywający na sprzedającym obowiązek wykazania tegoż przychodu i obliczenia podatku należnego od sumy uzyskanych dochodów według skali podatkowej. Natomiast w trakcie roku podatkowego nie ciąży obowiązek wpłacania zaliczek na podatek dochodowy od osób fizycznych. W ramach podatku VAT, punktem zwrotnym w podejściu organów podatkowych do kwestii opodatkowania był wyrok Trybunału Sprawiedliwości Unii Europejskiej w sprawie Skatteverket/David Hedqvist, w którym TSUE stwierdził, że zwolnienie z VAT jest przewidziane art. 135 ust. 1 lit. e) (Tabaka, 2018). Dyrektywa VAT obejmuje również świadczenie usług, które polegają na wymianie walut tradycyjnych na jednostki wirtualnej waluty i odwrotnie, dokonywane za zapłatą kwoty odpowiadającej marży wynikającej z różnicy pomiędzy ceną, po jakiej dany przedsiębiorca nabywa waluty, a ceną, po jakiej je sprzedaje klientom. Powyższe stanowisko TSUE jest stosowane obecnie przez organy podatkowe, które wcześniej odmawiały zastosowania zwolnienia do tego typu usług. W obecnych interpretacjach organy podatkowe stoją na stanowisku, iż do obrotu kryptowalutami ma zastosowanie zwolnienie z art. 43 ust.1 pkt 7 ustawy o podatku od towarów i usług odnoszące się do transakcji dotyczących walut, banknotów i monet używanych jako prawny środek płatniczy (Piech i Kacwin, 2017).

Rynek kryptowalut to wciąż rynek nieuregulowany, więc nie ma narzędzi, by konsumentów chronić. W momencie, gdy taki podmiot zakończyłby działalność z dnia na dzień, to instytucje nie są w stanie pomóc klientom w odzyskaniu ich środków. Niewątpliwie jednak w Polsce występuje niesprzyjający klimat regulacyjno-podatkowy oraz chaos informacyjny, co powoduje ograniczenie stosowania kryptowalut. Dodatkowo 4 banki (BZ WBK, mBank, PKO BP i Alior Bank) wypowiedziały umowy firmom, które prowadziły platformy umożliwiające inwestowanie w kryptowaluty. W wyniku takich działań największe giełdy wymiany kryptowalut w Polsce ogłosiły, że rozważają przeniesienie swojej działalności poza granice kraju. W tabeli 2 przedstawiono największe giełdy wymiany kryptowalut działające w Polsce. 


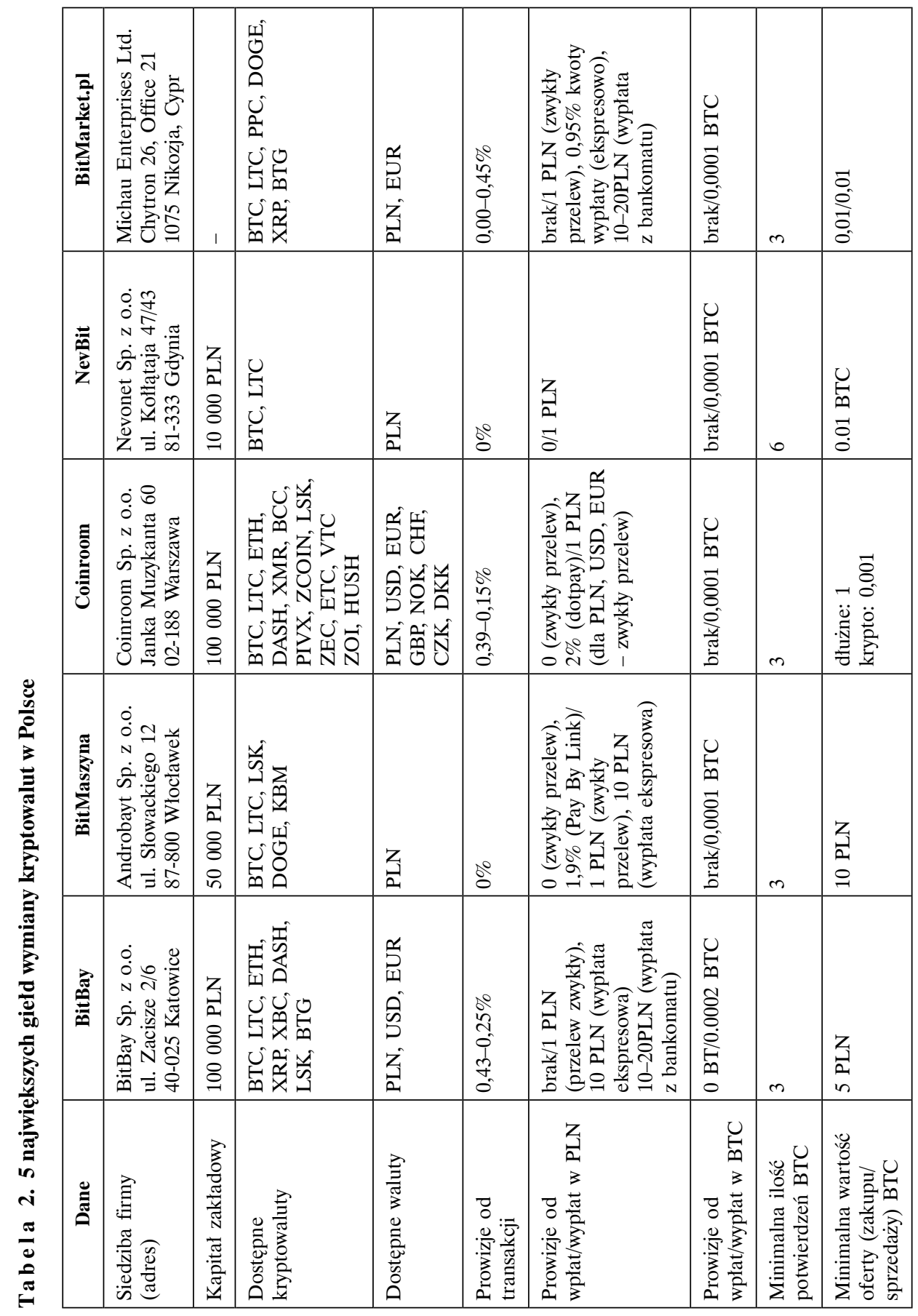




\begin{tabular}{|c|c|c|c|c|c|c|c|}
\hline 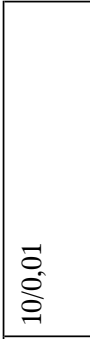 & 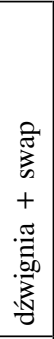 & 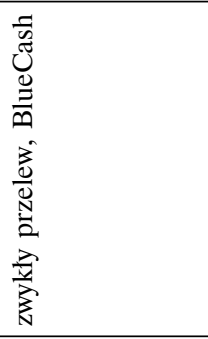 & 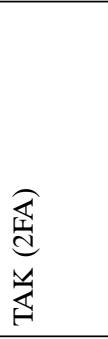 & 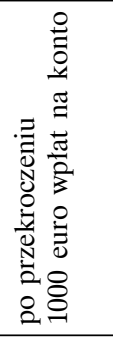 & 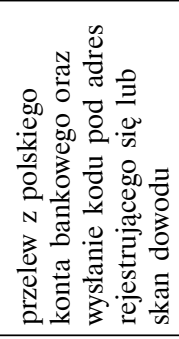 & 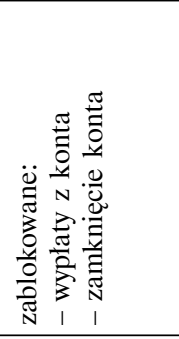 & 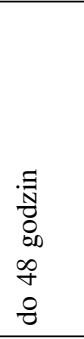 \\
\hline 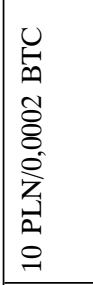 & 1 & 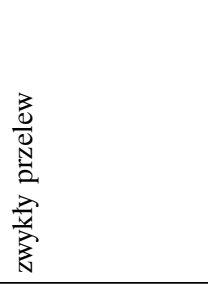 & 1 & 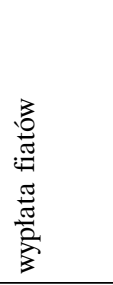 & 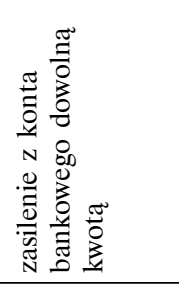 & 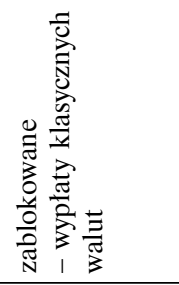 & 1 \\
\hline 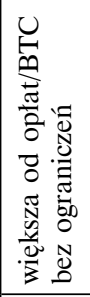 & 1 & 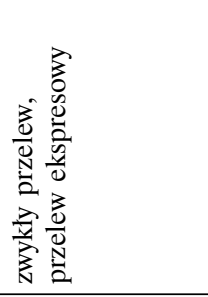 & 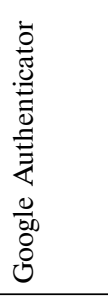 & 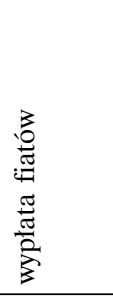 & 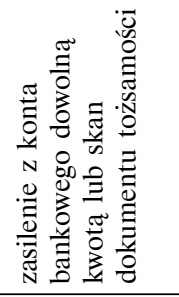 & 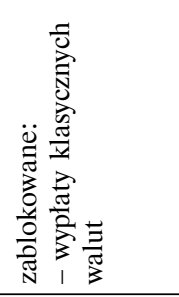 & 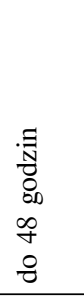 \\
\hline 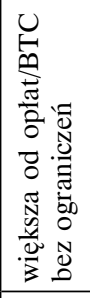 & 1 & 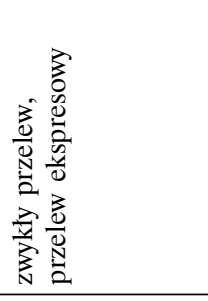 & $\begin{array}{l}\underset{d}{d} \\
\frac{1}{d} \\
\frac{1}{6}\end{array}$ & $\begin{array}{l}\overline{\mathcal{D}} \\
\bar{E} \\
\bar{\Xi}\end{array}$ & 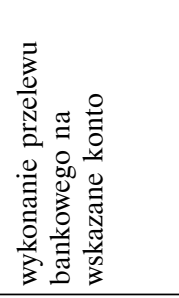 & 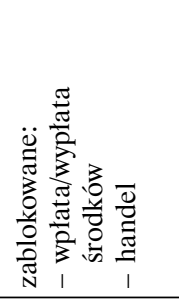 & 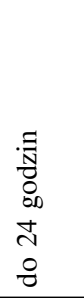 \\
\hline 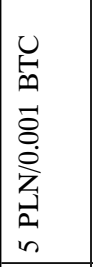 & 1 & 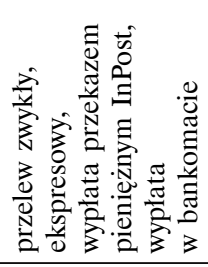 & 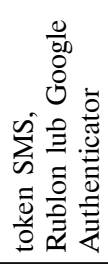 & 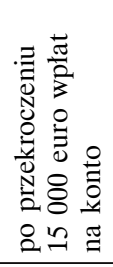 & 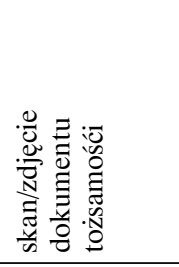 & 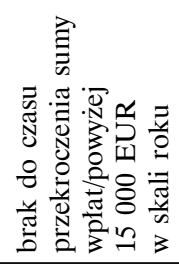 & $\begin{array}{l}\text { : } \\
0 \\
0 \\
0 \\
1 \\
7 \\
0 \\
0\end{array}$ \\
\hline 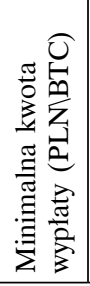 & 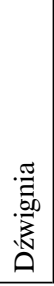 & $\begin{array}{l}\frac{\pi}{5} \\
\sum_{3}^{2} \\
\frac{2}{0} \\
0 \\
\sum\end{array}$ & 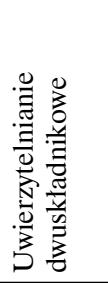 & 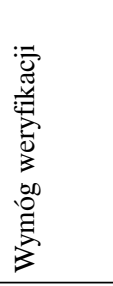 & 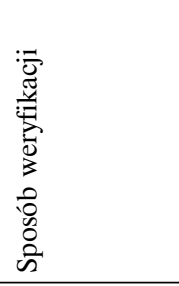 & 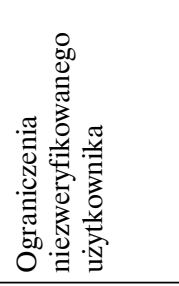 & 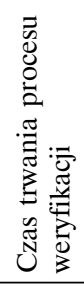 \\
\hline
\end{tabular}


Udział procentowy w roku 2017 przedstawionych giełd wymiany kryptowalut w Polsce wyglądał następująco: BitBay (49\%), Bitmarket.pl (28\%), Coinroom (16\%), Nevbit (4\%) i Bitmaszyna (3\%). Dzienne obroty na rynku kryptowalut w roku 2017 w Polsce sięgały 50 milionów PLN. Według Morgan Stanley, najwięcej zarejestrowanych giełd kryptowalutowych jest w Wielkiej Brytanii (https://www.polskieradio.pl, 2018).

Biorąc pod uwage obecnie istniejące kryptowaluty do trzech pierwszych kryptowalut polskich, które powstały na początku roku 2014 zaliczamy:

1. PolCoin (PLC) jest pierwszą polską wirtualną walutą. Powstała w styczniu 2014 roku jako klon zyskującego na popularności bitcoina. Oparty jest na tym samym algorytmie SHA256d. Obecnie jest to całkowicie polski projekt, w który zaangażowany jest wyłącznie polski zespół twórców oraz polski kapitał. Obecnie rozwija go trzeci już zespół developerów. PolCoin posiada stabilną sieć węzłów, a developerzy pracują nad jej rozwojem. Głównym założeniem, tak jak innych światowych kryptowalut, jest uwolnienie od niewoli banków. Zgodnie z założeniami wartość Polcoina powinna w długim horyzoncie czasowym rosnąc $\mathrm{z}$ powodu wbudowanego w system sztywnego ograniczenia podaży przy jednoczesnym wzroście popytu. Dodatkowym powodem do zwiększenia tempa wzrostu wartości waluty jest rosnąca świadomość na temat szeroko pojętych kryptowalut i ich użyteczności. Polcoin jest ponad państwowy, nie jest emitowany przez organ związany z żadną administracją państwową, a audytorem jest społeczność Polcoina. Już teraz używany jest jako środek płatniczy. Polcoinami obecnie można płacić m.in. w jednym sklepie stacjonarnym oraz kilku sklepach internetowych (PolCoin, 2014).

2. PolishCoin (PCC) - stworzony by pomóc ludziom z Polski w zrobieniu pierwszego kroku w świecie cyfrowych pieniędzy, ponieważ pod względem nowych technologii, dostępu do nich, a także świadomości ich istnienia, Polska zajmuje jedno z ostatnich miejsc w Europie. Eksperci uważają, że jak na razie jest to najlepiej przygotowana kryptowaluta z Polski, która jest dostępna na jednej z giełd wymiany kryptowalut. Docelowo twórcy chcą na tyle rozpowszechnić PolishCoin, aby trafił na światowe giełdy kryptowalut.

3. PLNcoin (PLNc) - 17 marca wystartowała kolejna polska kryptowaluta - PLNcoin. Twórcy tej monety jeszcze przed oficjalnym otwarciem wydobyli 2 mln monet. Rozdawali je za darmo w zamian za założenie konta na ich stronie. $\mathrm{Na}$ ich stronie powstało 16 tysięcy profili. Waluta pojawiła się na kilku giełdach, a firma organizująca podróże zagraniczne zadeklarowała, że respektuje wpłaty w PLNc obok bitcoina i litecoina. 
Twórcy polskich kryptowalut deklarują, że stworzyli je, by mieć możliwość płacenia w wirtualnym świecie bez kontroli instytucji bankowych czy rządu (Woźnicki, 2018). Jest to najczęściej wymieniany argument podkreślający zalety rozwoju nowego systemu finansowego opartego na kryptowalutach. Niestety występuje również wiele niekontrolowanych zagrożeń. Przykładowo sceptycy wskazują, że wielu twórców kryptowalut stara się wykorzystać panujący klimat społeczno-gospodarczy, aby zarobić dzięki pump and dump (pompuj i rzuć), czyli sztucznemu windowaniu cen, aby sprzedać monety lub akcje, gdy tylko inni się nimi zainteresują. Windują oni wartość kryptowaluty bez jakiejkolwiek intencji budowania nowej infrastruktury gospodarczej. Marzeniem twórców jest zaś, że pewnego dnia właśnie ich monety staną się środkiem płatniczym. Natomiast ludziom, którzy decydują się kopać i gromadzić monety - że nadrobią szansę przespaną przy bitcoinach. Nie ma jednak wątpliwości, że większość monet po kilku miesiącach trafi w niebyt (Jagiełowicz, 2018).

$\mathrm{Na}$ polskim rynku kryptowalut mamy na razie do czynienia $\mathrm{z}$ chaosem i destrukcją. Jedynym pozytywnym ruchem w stosunku do rynku kryptowalut był komunikat wydany przez organy państwowe mówiący, że obrót kryptowalutami nie narusza prawa krajowego i unijnego, choć ich posiadanie wiąże się z dużym ryzykiem. Należy zaznaczyć, że jest to stanowczo za mała aktywność organów ustawodawczych.

Podobnie jak na całym świecie, w Polsce również idzie się w kierunku wprowadzenia pewnych regulacji prawnych na rynku kryptowalut. Przykładem są nowe obowiązki informacyjne. Ministerstwo Finansów chce objąć obowiązkiem informacyjnym firmy handlujące kryptowalutami, takimi jak bitcoin. Zajmowali się tym posłowie Sejmowej Komisji Finansów Publicznych, którzy procedowali nad rządowym projektem ustawy o przeciwdziałaniu praniu pieniędzy i finansowaniu terroryzmu. Obecnie na podpis prezydenta czeka pierwsza polska ustawa dotycząca kryptowalut. O nich i technologii blockchain dyskutowali m.in. eksperci Narodowego Banku Polskiego i Komisji Nadzoru Finansowego. Jednak na całkowite prawne uregulowanie tej kwestii trzeba będzie jeszcze poczekać co najmniej dwa lata. Jest to dobry kierunek, który już funkcjonuje na przykład w Japonii. Niewątpliwie należy analizować historię kryptowalut w państwach, które w tym sektorze mają doświadczenia dzięki szybszemu rozwojowi i to, można powiedzieć, o lata. Upadek giełdy wymiany kryptowalut w Japonii miał bowiem miejsce już w 2014 roku i na tych doświadczeniach wprowadzono regulacje, które teraz będą wprowadzane w Polsce. Szkoda tylko, że korzystając z doświadczeń innych funkcjonujących rynków, nie zrobiono tego wcześniej, ponieważ w Polsce historia się powtórzyła, a wprowadzane regulacje są pokłosiem upadku giełdy kryptowalut Bitcurex. W październiku 
2016 roku giełda została nagle zamknięta, a ponad 2 tysiące bitcoinów należących do użytkowników zdefraudowano.

W wyniku braku regulacji żadne instytucje ochrony inwestorów czy konsumentów nie mają niestety prawnych możliwości pomocy. Do najważniejszych czynników, które wpływają na kursy kryptowalut zaliczamy:

- zaufanie użytkowników oraz inwestorów - kryptowaluty to wirtualne pieniądze, które nie posiadają żadnej formy fizycznej; ich wartość w głównej mierze jest uzasadniona ofertą i popytem użytkowników (Miciuła, 2014); jeżeli popyt na kryptowaluty wzrasta, to podwyższa się również ich kurs; odwrotnie, jeśli ludzie się pozbywają kryptowalut, ich kurs zmaleje;

- możliwości wykorzystania kryptowalut - kryptowaluty powstały jako waluta wirtualna dla szybkich i tanich transakcji internetowych; im więcej sprzedawców wspiera i przyjmuje kryptowaluty, tym bardziej poszerza się możliwość ich wykorzystania w praktyce oraz tym większa będzie również społeczność użytkowników; w związku z długotrwale rosnącą wartością kryptowalut są one coraz częściej wykorzystywane w celach inwestycyjnych; w państwach o niestabilnej gospodarce występują waluty wirtualne kupowane w celu zachowania wartości własnych pieniędzy; kryptowaluty bez możliwości praktycznego wykorzystania wcześniej lub później przestaną istnieć;

- interwencja organów regulacyjnych i nadzorczych - jeżeli rząd zaczyna wspierać kryptowaluty, zaufanie użytkowników zazwyczaj rośnie, co powoduje również wzrost wartości tej kryptowaluty (Miączyński, 2017); przykładowo, kiedy w kwietniu 2017 r. Japonia uznała bitcoin za walutę legalną to jego wartość znacznie się zwiększyła; działa to jednak również odwrotnie; ograniczenia lub zakazy kryptowalut ze strony urzędów państwowych mogą rozpocząć gwałtowny spadek rynku, np. we wrześniu 2017 r. Chiny zakazały kryptowalut, co spowodowało spadek kursu;

- uwaga mediów - informacje o wzrastającej wartości kryptowalut przyciągają nowych inwestorów, co powoduje podwyższenie popytu i kursu kryptowalut; również poglądy znanych osobistości i firm wpływają na wzrost lub spadek cen; przykładem była opinia dyrektora generalnego JPMorgan, Jamiego Dimona, z września 2017 roku, który określił bitcoin jako oszustwo i powiedział, że właściciele bitcoinów w przyszłości poniosą wielkie straty; rynek bitcoinu na ową wiadomość reagował spadkiem (Investplus, 2018);

- manipulowanie kursami - inwestorzy wykorzystują technikę manipulacyjną, znaną pt. „pump and dump“; owa technika polega na zakupie kryptowaluty po niskim kursie i jej późniejszej medialnej propagacji; to przyciągnie nowych inwestorów, którzy spowodują wzrost kursu (Miciuła, 2015). 
Mechanizm ten dotyczy często samych twórców lub organizatorów i zarządzających wieloma kryptowalutami, które powstają w celach stworzenia swoistej piramidy finansowej, tylko i wyłącznie w celach własnego zarobku; owa metoda (kupić tanio - przekonać innych do zakupu - drogo sprzedać) nie sprzyja niestety naturalnemu rozwojowi kryptowalut;

- czynniki technologiczne (twórcy, zarządcy, regulatorzy) - zmianą kursu można również manipulować przez zmiany w kodzie źródłowym, przykładowo przez implementację różnych ulepszeń lub zmian w liczbie monet dostępnych na rynku;

- czynniki organizacyjne - przykładowo czynniki wpływające na wydobywanie kryptowaluty (trudności wydobycia czy cena energii, która, jak pokazują analizy w literaturze przedmiotu, dochodzi do ogromnych wartości porównywalnych z energią potrzebną na zaspokojenie tysięcy gospodarstw domowych) (Luther, 2016);

- Substytuty - w końcu nawet aktywa na giełdzie wpływają na siebie wzajemnie, rosnące zainteresowanie bitcoinem niektórzy uważają za przyczynę spadku złota itp.; natomiast wartość bitcoina ma wpływ na kursy innych walut kryptograficznych, które stają się alternatywą dla innych inwestycji czy spekulacji.

\section{Podsumowanie}

Kryptowaluty nie są kontrolowane przez rządy ani banki centralne. Państwa stosują najczęściej dwie taktyki. Jedna grupa krajów przyjęła strategię strusia, mając nadzieję, że moda sama przeminie i ogólnie nie wprowadza na ten temat żadnych regulacji, jedynie te które wynikają z prawa krajów zrzeszonych, czyli dotyczą na przykład państw członkowskich Unii Europejskiej, jak w przypadku Polski. Natomiast druga - chce spróbować przejąć częściową kontrolę i zarabiać na niej. Przykładowo w Japonii bitcoin stał się pełnoprawnym środkiem płatniczym. Jednak ze względu na doświadczenie (upadek w 2014 roku giełdy Mt. Gox i zniknięcie 850 tysięcy bitcoinów) rząd Japonii wprowadza jasno określone uregulowania. Podmioty, które chcą prowadzić usługi wymiany kryptowalut muszą widnieć w rejestrze Agencji Usług Finansowych Japonii, która prowadzi dodatkowy nadzór. Takie kraje, jak Rosja, Ukraina, Białoruś czy Litwa opowiadają się za chęcią zarabiania. Kraje te będące w pobliżu Polski ze względu na wprowadzone ograniczenia i niejasne działania organów państwowych po prostu przejmą uczestników rynku kryptowalut i to one będą zarabiać. Natomiast rząd Polski w ramach realnej aktywności robi niewiele. Co prawda w końcu częściowo rozwiązano chaos związany z interpretacją podatkową doty- 
czącą rynku kryptowalut, ale nie rozwiano ostatecznie wszelkich wątpliwości, co wpływa negatywnie na inwestorów. Rząd Polski stwierdził bowiem, że na razie nie zamierza w tej sprawie wydawać ogólnej interpretacji podatkowej. Jak twierdzą analitycy przez te zaniedbania (brak regulacji prawnych) i pozostawanie w tyle po prostu tracimy swoją szansę, przykładowo za rok 2016 omawiana branża w Polsce zapłaciła ponad $100 \mathrm{mln}$ zł podatków.

Według Wall Street Journal w kryptowaluty inwestuje obecnie ponad 70 funduszy hedgingowych, a każdego dnia wartość operacji dokonanych bitcoinami sięga 750 mln dolarów. Maksymalna założona ilość bitcoinów przez twórców to $21 \mathrm{mln}$, a obecnie w użyciu jest ponad 17 milionów, z pewnością więc nastąpią zmiany w założeniach oraz funkcjonowaniu całych rynków kryptowalut. Najczęstszymi opiniami są te, że wirtualne waluty będą nowym etapem rozwoju lub rajem dla oszustów. Należy wprowadzić pewne rozwiązania i regulacje, w tym niewykluczone, że oparte na zaufaniu do instytucji międzynarodowych, które spowodują przesunięcie prawdopodobieństwa wykorzystania możliwości stosowania kryptowalut w stronę rozwoju społeczeństwa informacyjnego, ograniczając tym samym możliwości oszustom i innym przestępstwom.

\section{Bibliografia}

Abram, G. i Szymura, T. (2017). Bitcoin - still cryptocurrency or currency? Pozyskano z http:// www.infor.pl/Bitcoin-jeszcze-kryptowaluta-czy-juz-waluta.html\#ftn16 (22.10.2018).

Bitcoin.pl. (2018) The review of Polish stock exchanges for cryptocurrencies. Pozyskano z http:// bitcoin.pl/zestawienie-gield (02.10.2018).

Coindesk. (2018). Bitcoin (USD) Price. Pozyskano z https://www.coindesk.com/price/ (15.10.2018).

Polskieradio. (2018). Cryptocurrencies - whether investing in them is safe? Pozyskano z https:// www.polskieradio.pl/Artykul/2068287,Jak-uregulowac-obrot-kryptowalutami (30.04.2018).

Chaparro, F. (2018). 97 percent bitcoin are kept in only 4 percent all portfolios. Pozyskano $\mathrm{z}$ https://businessinsider.com.pl/finance/kryptowaluty/analiza-credit-suisse/6g9r9zg (22.04.2018).

Christin, N. (2013). Traveling the silk road: A measurement analysis of a large anonymous online marketplace. W: Proceedings of the 22nd International World Wide Web Conference (s. 213-224). Rio de Janeiro.

Investopedia. (2018). What is a Cryptocurrency. Pozyskano z https://www.investopedia.com/ terms/c/cryptocurrency.asp (28.08.2018).

Investplus. (2018). Cryptocurrencies - courses. Pozyskano z https://investplus.cz/pl/kryptowaluty-kursy-pln-usd-ranking-kryptowalut/ (20.06.2018).

Jagiełowicz, M. (2018). Cryptocurrencies - to invest or not? Pozyskano z https://www.polskieradio.pl/42/273/Artykul/2107569,Kryptowaluty-czy-inwestowanie-w-nie-jest-bezpieczne (21.06.2018).

Luther, W.J. (2016). Cryptocurrencies, network effects and switching costs. Contemporary Economic Policy, 34, 553-571. 
Miączyński, P. (2017). The government is beginning to notice cryptocurrencies. Economy, 7.

Miciuła, I. (2014). The concept of FTS analysis in forecasting trends of exchange rate changes. Economics \& Sociology, 7(2), 172-182.

Miciuła, I. (2015). Financial innovations on the currency market as new instruments to risk management. Journal of International Studies, 8(1), 138-149.

Money. (2018). BitCoin. Pozyskano z https://www.money.pl/pieniadze/bitcoin/ (14.09.2018).

Moneycontrol. (2018). Philippines boxer to launch his own cryptocurrency. Pozyskano z https:// www.moneycontrol.com/news/business/cryptocurrency/philippines-boxer-to-launch-hisown-cryptocurrency-2553257.html (21.08.2018).

Piech, K. i Kacwin, M. (2017). Stan rynku kryptowalut $w$ Polsce oraz możliwe przychody podatkowe państwa. Pozyskano z https://www.gov.pl/documents/31305/Stan+rynku+kryptowalut +w+Polsce.pdf (03.10.2018).

PolCoin. (2014). What is PolCoin? Pozyskano z https://polcoin.pl/ (12.09.2018).

Ratajczak, M. (2018). Niecodzienny protest inwestujacych w kryptowaluty. Pozyskano z https:// www.money.pl/gospodarka/artykul/rozliczenie-kryptowalut-podatki-protest,185,0,2403001. html (18.09.2018).

Rosic, A. (2018). What is Cryptocurrency: Everything You Need To Know. Pozyskano z https:// blockgeeks.com/what-is-cryptocurrency/ (02.08.2018).

Satoshi, N. (2008). Bitcoin: A Peer-to-Peer Electronic Cash System. Pozyskano z http://bitcoin. org/bitcoin.pdf (04.11.2018).

Tabaka, M. (2018). Polish investors are plunged into the chaos of tax interpretations regarding cryptocurrencies. Pozyskano z https://www.spidersweb.pl/2018/04/chaos-w-rozliczeniachpodatkowych-z-kryptowalut.html (26.09.2018).

Woźnicki, Ł. (2018). PolishCoin, PolCoin i PLNc-three Polish cryptocurrencies. Pozyskano z http://wyborcza.pl/1,76842,15707096,PolishCoin_PolCoin_i_PLNc_html (15.10.2018). 


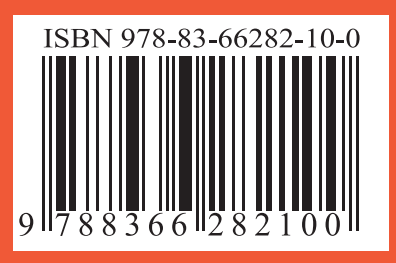

